\title{
Conodonts from the Genesee Formation in Western New York
}

GEOLOGICAL SURVEY PROFESSIONAL PAPER 1032 - B

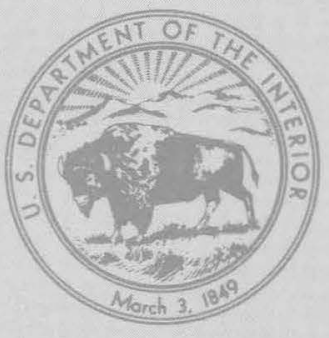




\section{Conodonts from the Genesee Formation in Western New York}

By JOHN W. HUDDLE, assisted by JOHN E. REPETSKI

STRATIGRAPHY AND CONODONTS OF

THE GENESEE FORMATION (DEVONIAN)

IN WESTERN AND CENTRAL NEW YORK

GEOLOGICAL SURVEY PROFESSIONAL PAPER 1032-B

Conodonts from the Genesee Formation in western New York, first described by G. J. Hinde in 1879 and $W$. L. Bryant in 1921, are redescribed, and the biostratigraphic zones are determined

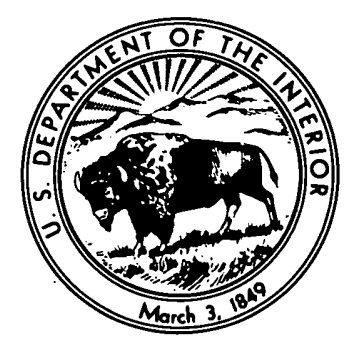




\section{UNITED STATES DEPARTMENT OF THE INTERIOR}

JAMES G. WATT, Secretary

\section{GEOLOGICAL SURVEY}

Doyle G. Frederick, Acting Director

Library of Congress Cataloging in Publication Data

Huddle, John Warfield, 1907-1975

Conoulonts from the Genesee Formation in western New York.

(Stratigraphy and conodonts of the Genesee Formation (Devonian) in western and central New York) (Geological Survey professional paper ; 1032-B) Bibliography: p.

Supt. of Docs. No.: I 19.16:1032-B

1. Conodonts. 2. Paleontology-Devonian. 3. Paleontology-New York (State) I. Title. II. Series. III. Series: United States. Geological Survey. Professional paper ; 1032-B.

QE899.H83 $557.3^{\prime} 08 \mathrm{~s}$ [562]

$77-608125$

For sale by the Distribution Branch, U.S. Geological Survey, 604 South Pickett Street, Alexandria, VA 22304 


\section{FOREWORD}

After John Huddle's death in late November 1975, I was asked to serve as author's representative in the completion of this report. In September 1975, Huddle had completed the posttechnical review copy of his manuscript and had forwarded it for U.S. Geological Survey publication approval. I received the edited manuscript in September 1976, for review of accuracy of taxonomy and of technical matters and details noted by the Survey editors and by myself. My contribution consisted of checking for, and correcting where necessary, objective errors in the manuscript. In making necessary changes, I relied on Huddle's most recent worksheets, notes, and notes on specimen slides as much as possible in order to preserve the integrity of his work. No changes were made in subjective matters of taxonomy or of interpretation. Throughout my efforts on this paper, I have tried to avoid making any changes that would have affected Huddle's substance or style, so that this published report would be as much as possible John Huddle's original work.

John E. Repetski

U.S. Geological Survey

Washington, D.C.

$1 / 12 / 77$ 



\section{CONTENTS}

Abstract

Introduction

Purpose of the investigation

Fieldwork

Laboratory preparation

Previous work

Acknowledgments

Occurrence of conodonts in the Genesee Formation -

Distribution and abundance -........-.

Reworked conodonts, lag concentrates, and unconformities

Facies distribution

Biostratigraphy

Ammonoid zonation

Amodont zonation

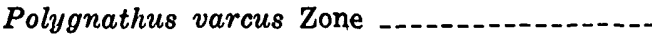

Schmidtognathus hermanni-Polygnathus cri-

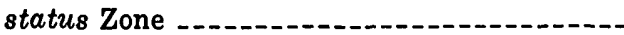

Polygnathus asymmetricus Zone -.........-

Problems in using the European range zones in western New York

Sequence of first appearances in the New York Genesee Formation -.....

Application of conodont zonation to New York formations

Age of the Windom Member of the Moscow Shale and the Tully Limestone

Age of the Geneseo Shale Member and associated beds of the Genesee Formation -.-

\begin{tabular}{|c|c|c|}
\hline Page & & Page \\
\hline B1 & Biostratigraphy-Continued & \\
\hline 1 & Application of conodont zonation to New York & \\
\hline 1 & formations-Continued & \\
\hline 2 & Age of the Penn Yan Shale Member of the & \\
\hline 2 & Genesee Formation & B15 \\
\hline 2 & Age of the Williams Brook Coquinite Member & \\
\hline 3 & of Ithaca facies of Caster (1933) & 15 \\
\hline 3 & Age of the Genundewa Limestone Member & \\
\hline 3 & $\begin{array}{l}\text { of the Genesee Formation } \\
\text { Age of the Crosby Sandstone Member of the }\end{array}$ & 16 \\
\hline 3 & $\begin{array}{l}\text { Standish Formation as used by Torrey and } \\
\text { others }(1932)\end{array}$ & \\
\hline 9 & Age of the West River Shale Member of the & 10 \\
\hline 9 & Genesee Formation & 16 \\
\hline 9 & Systematic paleontology of conodonts & 16 \\
\hline 9 & Multielement versus element taxonomy _...-- & 16 \\
\hline 11 & Why element taxonomy is used in this report & 18 \\
\hline & Locality numbers and type depository & 18 \\
\hline 12 & Description of genera and species & 19 \\
\hline 12 & Platform and blade elements & 19 \\
\hline & Platform elements & 19 \\
\hline 12 & Blade elements & 33 \\
\hline & Ozarkodinan elements & 34 \\
\hline 13 & Neoprioniodontan elements & 39 \\
\hline & Hindeodellan elements & 41 \\
\hline 14 & Ligonodinan elements & 44 \\
\hline & Lonchodinan elements & 15 \\
\hline 14 & Locality list & 47 \\
\hline & References cited & 57 \\
\hline 14 & Index & 63 \\
\hline
\end{tabular}

\section{ILLUSTRATIONS}

Plate 1-3. Ancyrodella.

[Plates 1-31 following index]

\section{4, 5. Icriodus.}

6. Palmatolepis? and Polygnathus.

7-17. Polygnathus.

18. Polygnathus and Nothognathella.

19. Prioniodina, Polygnathus, Spathognathodus, Pandorinellina, and Synprioniodina.

20. Bryantodus and Ozarkodina.

21. Bryantodus.

22. Bryantodus and Ozarkodina.

23. Neoprioniodus and Synprioniodina.

24. Hindeodella.

25. Hindeodella and Angulodus.

26. Bryantodus, Angulodus, Ozarkodina, and Enantiognathus.

27. Enantiognathus and Ligonodina.

28. Ligonodina and Prioniodina.

29. Bryantodus, Prioniodina, Lonchodina, and Trichonodella.

30. Prioniodina, Lonchodina, Trichonodella, and Bryantodus?.

31. Bryantodus, Lonchodina, and Prioniodina. 
Plate 32. Diagram showing the sequential appearance of conodont species in the basal beds of the Genesee For-

mation

FIGURE 1. Stratigraphy and conodont zonation of the Belgian Frasnian stratotype section

\section{TABLES}

TABLE 1. Occurrence of conodonts by species, sample number, and stratigraphic units

2. Range chart of conodont species by first appearances

3. Occurrence, from west to east for each member, of conodonts in samples of the Windom Member of the Moscow Shale and the Tully Limestone

4. Occurrence, from west to east, of platform and blade conodonts in the Leicester Marcasite Member of Moscow Formation of Sutton (1951) and the North Evans Limestone of Rickard (1964)

5. Early Late Devonian ammonoid zonation in Europe and New York

6. Comparison of European and North American conodont zonation 


\title{
STRATIGRAPHY AND CONODONTS OF THE GENESEE FORMATION (DEVONIAN)
}

IN WESTERN AND CENTRAL NEW YORK

\section{CONODONTS FROM THE GENESEE FORMATION IN WESTERN NEW YORK}

\author{
By John W. HuddLe, ${ }^{1}$ assisted by John E. REPETSKI
}

\section{ABSTRACT}

Conodonts from the Genesee Formation in western New York were first described by G. J. Hinde in 1879, and conodonts from the "conodont bed" (North Evans Limestone of Rickard, 1964) were described by W. L. Bryant in 1921. Many new species and genera were named in these reports, and a multielement species was proposed by Hinde. Taxonomic revision, redescription, and improved illustrations of these species are given in the present report, which also documents the ranges of conodonts in the classic New York Devonian section and relates their ranges to the occurrence of ammonoids. Sixty-eight element species of conodonts are described, including one new species, Polygnathus collieri, and three new subspecies, Polygnathus rhenanus marijae, $P$. asymmetricus unilabius, and $P$. dubius frons.

\section{INTRODUCTION}

\section{PURPOSE OF THE INVESTIGATION}

Chapter A of this Professional Paper (de Witt and Colton, 1978) is the report of work done by U.S. Geological Survey parties under the direction of James F. Pepper as part of a study of the origin and occurrence of black petroliferous shales. Field parties began measuring sections and mapping in 1947. More than 400 sections were measured in detail, and regional correlations were made by mapping key beds and comparing the lithologic sequence in closely spaced stratigraphic sections. The results of the study of the Genesee Formation were summarized previously by de Witt and Colton (1959) and are expanded by them in Chapter $A$ of this Professional Paper (de Witt and Colton, 1978). W. H. Hass cooperated in the stratigraphic studies of the Upper Devonian of western New York and northwestern Pennsylvania by collecting conodonts from the carefully measured sections. His material was used to confirm lithologic correlations or to provide paleontologic correlations where lithologic correlations were uncertain. Hass was concerned primarily with the establishment of the ranges of conodont species in the classic Upper Devonian ref- erence section in North America and with the correlation of these rocks with Upper Devonian rocks in other areas. These studies were intended to aid in the search for oil and gas in New York, Pennsylvania, and Ohio.

This study of the conodont faunas of the Genesee Formation in western New York was carried out from 1956 to 1959 by W. H. Hass in cooperation with a study of the physical stratigraphy of the formation by Wallace de Witt, Jr., and G. W. Colton. I continued the study of the conodonts after 1962.

The sequence of first appearances of conodont species in New York does not correspond to that of the standard European conodont zonation; the zonation of Klapper and others (1971) for North America is used here for the conodont zones near the boundary between the Middle and Upper Devonian. Conodont zones near this boundary need revision, but such revision is not done here. The boundary between the Middle and Upper Devonian is not discussed here because it is not definable in central and western New York until international agreement is reached on the position in the European stratotype section.

Element taxonomy is used in this report; the elements are grouped under the headings of platforms and blades, ozarkodinan, neoprioniodontan, hindeodellan, ligonodinan, and lonchodinan elements. These groups probably represent positions in the multielement conodont apparatuses. Many of the collections here reported contain sorted or reworked conodonts, and the number of specimens in collections are not adequate for statistical studies to define multielement apparatuses. Sixty-eight element species are described, including one new species, Polygnathus collieri, and three new subspecies, Polygnathus rhenanus marijae, $P$. asymmetricus unilabius, and P. dubius frons.

${ }^{1}$ Deceased November 1975. 


\section{FIELDWORK}

Nearly all the collections used in this report were made by Hass between 1956 and 1959. A few samples were collected as early as 1944 in connection with other projects. Hass' field notes and collections show that he collected conodonts visible with the aid of a hand lens from black shales, siltstones, and sandstones. Calcareous rocks and soft shales (chewable) were collected in bulk for laboratory preparation. All collections came from thin intervals-0.01 foot to a few feet. No standard sample interval was used, nor is one practical in this sequence of clastic rocks. Hass collected from the type and standard sections of each named unit. The distribution of the samples that produced conodonts is shown by de Witt and Colton (1978, pls. 2-6). De Witt, Colton, M. J. Bergin, and other members of Survey parties occasionally assisted Hass in collecting. I made additional collections with de Witt, M. R. House, W. T. Kirchgasser, L. V. Rickard, and J. W. Wells.

\section{LABORATORY PREPARATION}

Shale and sandstone samples containing conodonts visible with a hand lens were studied under a binocular microscope. The conodonts were circled with a red pencil, and the rocks were trimmed to small chips. Most specimens were identified in the rock. A few, however, were dissolved with hydrochloric acid, and latex replicas were prepared; others were exposed with a needle. The calcareous samples were split, part placed in reserve, and part dissolved in acetic acid. No record was kept of the weight of the sample dissolved. The coarse residues and the lightand heavy-mineral separations were preserved. The conodonts were picked and placed in glass vials. After studying each sample, Hass counted the number of specimens in each element species and returned all conodonts to the vial. Only the specimens he intended to have photographed were placed on cardboard microfossil slides.

Most of the samples were prepared by F. J. Collier for W. H. Hass. After 1962, the samples collected were prepared by William Chamberlin, Carol Larmon Wolfe, and Marija Balanc. The photographs were taken by N. W. Shupe, Robert H. McKinney, Daivd H. Massie, Robert Willson, and myself. Drawings of some species were made by Roberta $C$. Wigder.

\section{PREVIOUS WORK}

Conodonts from the "conodont bed" (or North Evans Limestone of Rickard, 1964) and from the Geneseo Shale Member of the Genesee Formation were described by Hinde (1879), Grabau (1898-99), and Bryant (1921). The "conodont bed" became famous, and collections from it were distributed widely. Raymond Hibbard, a local collector and associate of the Buffalo Natural History Museum, collected extensively from the Genesee Formation. His collections from the North Evans Limestone of Rickard (1964) at Amsdell Creek contain many well-preserved specimens, and these have been distributed widely to conodont workers around the world. Hibbard's collection is now at the University of Michigan Museum of Paleontology at Ann Arbor, Mich.

Many new species and genera were described by Hinde (1879), who proposed a multielement species, Polygnathus dubius. Bryant (1921) proposed some new single-element species. Grabau (1898-99) republished Hinde's figures but did not propose any new species. The species and genera described by Hinde (1879) and Bryant (1921) are the oldest names for several forms that are involved in taxonomic problems related to the change from element to multielement conodont taxonomy. These forms are redescribed and reillustrated here.

Hass $(1958,1959)$ summarized the results of his Late Devonian conodont studies in western New York and northwestern Pennsylvania. In the months prior to his death (November 1959), Hass had been engaged in reviewing stratigraphic literature on the Upper Devonian of the Applachian region for a paper on the Genesee conodonts of New York. The only manuscript pages found of that paper were descriptions of 14 species (eight of them new), a partial plate, many photographs, a chart listing species and counts at 30 localities, and a chart showing revised nomenclature of Bryant's 1921 conodont species.

After Hass' death, I was asked to return to the study of conodonts and to complete as much as possible the work he had in progress. After completing another assignment in 1962, I started to work on conodonts. Unfortunately, I was not able to pick up where Hass stopped or to complete the project quickly. Originally, I planned to prepare the paper on the Genesee conodonts as a joint publication, but I have so changed the taxonomic treatment that I feel that I should take full responsibility, rather than share it with my friend, Wilbert Hass. The rapid progress of conodont research has resulted in many changes of nomenclature, and the species descriptions prepared by Hass are not used in this report. Most of the species that were new in 1959 have been described. However, in spite of 
the changes in conodont taxonomy and the improvement of conodont zonation since 1959 , the conclusions made in Hass' 1958 and 1959 papers are essentially confirmed.

\section{ACKNOWLEDGMENTS}

I am deeply indebted to Wallace de Witt, Jr., Michael R. House, Wm. T. Kirchgasser, L. V. Rickard, and John W. Wells for guidance in the field. Wells and Rickard loaned collections from several localities, and R. V. Kesling loaned several specimens from the Hibbard Collection at the University of Michigan Museum of Paleontology. Mrs. W. H. Hass and I. G. Sohn were very helpful in going over manuscript materials and determining the stage of preparation of Hass' manuscript before I undertook the completion of the project. Wallace de Witt, Jr., Willi Ziegler, C. A. Sandberg, W. T. Kirchgasser, and Gilbert Klapper reviewed and improved my manuscript. P. Bultynck and A. N. Mouravieff assisted with my study of Icriodus and Ancyrodella. I appreciate the cooperation of R. H. Bate in making available types at the British Museum of Natural History.

\section{OCCURRENCE OF CONODONTS IN THE GENESEE FORMATION}

\section{DISTRIBUTION AND ABUNDANCE}

The distribution and abundance of conodonts in the Genesee Formation are shown in tables $1-4$, and the stratigraphic positions of the samples producing conodonts are shown by locality numbers on plates 2-6 of de Witt and Colton (1978). Barren samples are not shown. Not all sections were collected for conodonts, and plates 2-6 of de Witt and Colton show that the conodont-bearing samples are widely separated at many localities. In the Upper Devonian rocks of western New York, which are dominantly clastic, conodonts are scarce and difficult to collect, except in the few calcareous units, including the Genundewa Limestone Member of the Genesee, North Evans Limestone of Rickard (1964), Leicester Marcasite Member of the Moscow Formation of Sutton (1951), and the calcareous nodules and concretions of the other members of the Genesee.

Conodonts are found in all kinds of marine sedimentary rocks. In black shales, conodonts generally are rare, but they occur occasionally in great numbers along some bedding planes and in silty laminae. Collections made by Raymond R. Hibbard from the Rhinestreet Shale Member of the West Falls Formation and described by Ulrich and Bassler (1926) are examples of this great abundance of conodonts on some bedding planes. Abundant accumulations of conodonts are due to mass deaths in some places and to slow deposition or winnowing in others. The latter two situations produce lag accumulations with sand grains in some places. In massive siltstone, conodonts are rare except in lag zones, and the difficulty in disaggregating the rock without breaking the conodonts hinders greatly the recovery of free conodonts in the laboratory. Samples of calcareous sandstone and siltstone containing abundant brachiopods and other fossils usually produced only a few unidentifiable conodont fragments unless the rock was so calcareous that the sand and silt grains separated readily. Many conodonts are broken against sand grains during the compaction of the rock. Whole conodonts are sparse in dense aphanitic concretions and septaria, but at many localities they are numerous in limestone concretions that tend to coalesce and in limestone lenses. Fine-grained medium-gray calcareous concretions that contain visible megafossils and microfossils are the most likely to contain conodonts. The brownish-gray limestone, although very argillaceous, also contains abundant conodonts at some localities. The Genundewa Limestone Member is an example of a brownish-gray limestone with abundant styliolinids that contains numerous well-preserved conodonts.

\section{REWORKED CONODONTS, LAG CONCENTRATES, AND UNCONFORMITIES}

During transportation by currents, conodonts behave as heavy minerals because they are composed mainly of the heavy mineral apatite (specific gravity 3.1-3.2), but the various shapes of conodonts cause hydrodynamic sorting. Those having thick plates tend to withstand transportation and to concentrate in the lag deposits and crossbedded sediments in the base of sedimentary units. The bar and blade elements, which are smaller, lighter, and are more easily transported than plate elements, tend to break during transport. An abundance of whole bars and blades generally indicates that the enclosing sediments were deposited in a low-energy environment and that the conodonts were not sorted or reworked from preexisting deposits. Conodont collections from the Genesee Formation come from low- to high-energy environments. The lithologies and conditions of deposition of the various units and members of the Genesee Formation have been discussed by de Witt and Colton (1978). The North Evans Limestone of Rickard (1964), the Crosby Sandstone of the Standish Formation as used by Torrey and others (1932), the Leicester Marcasite 


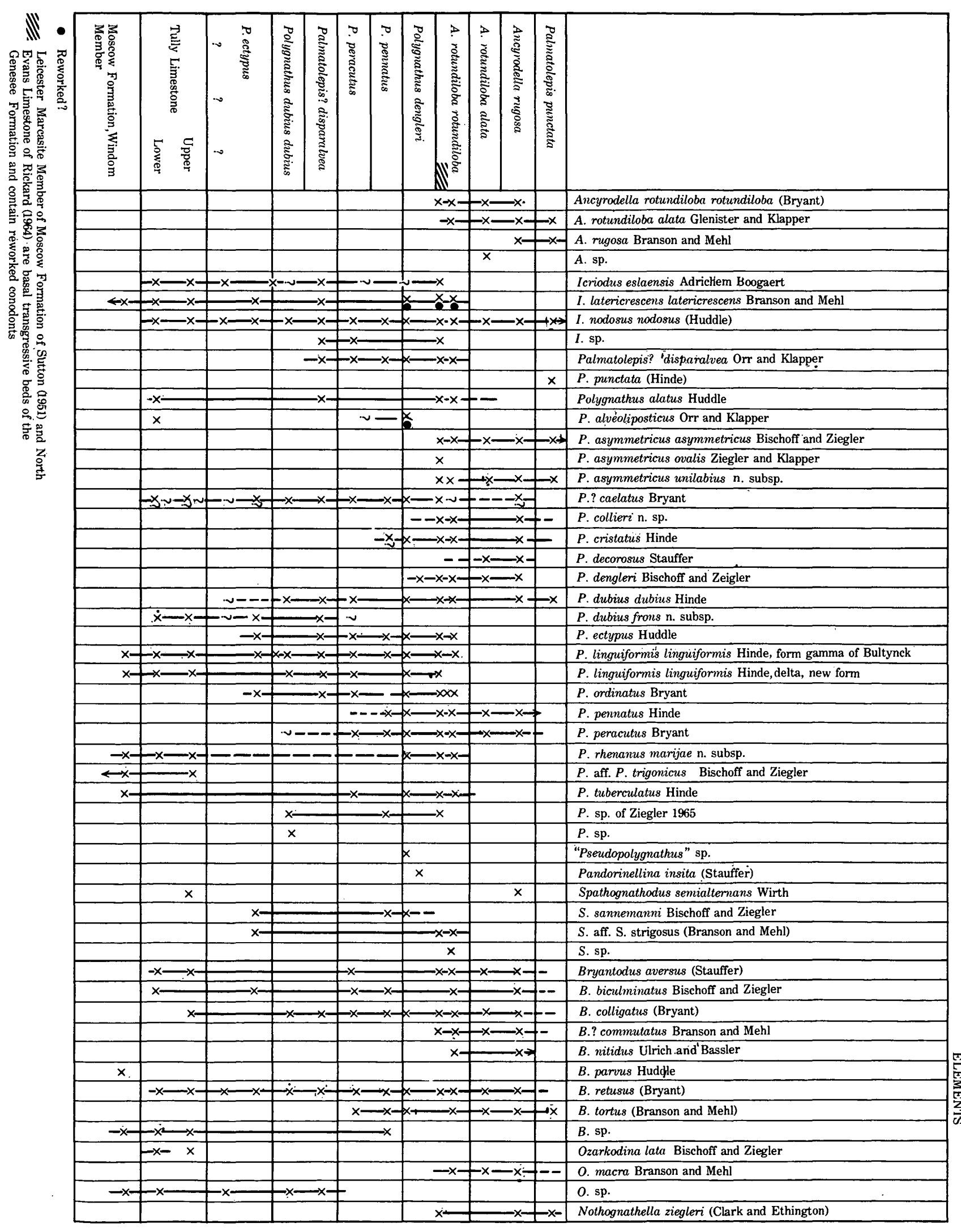


TABLE 2.-Range chart of conodont species by first appearance-Continued

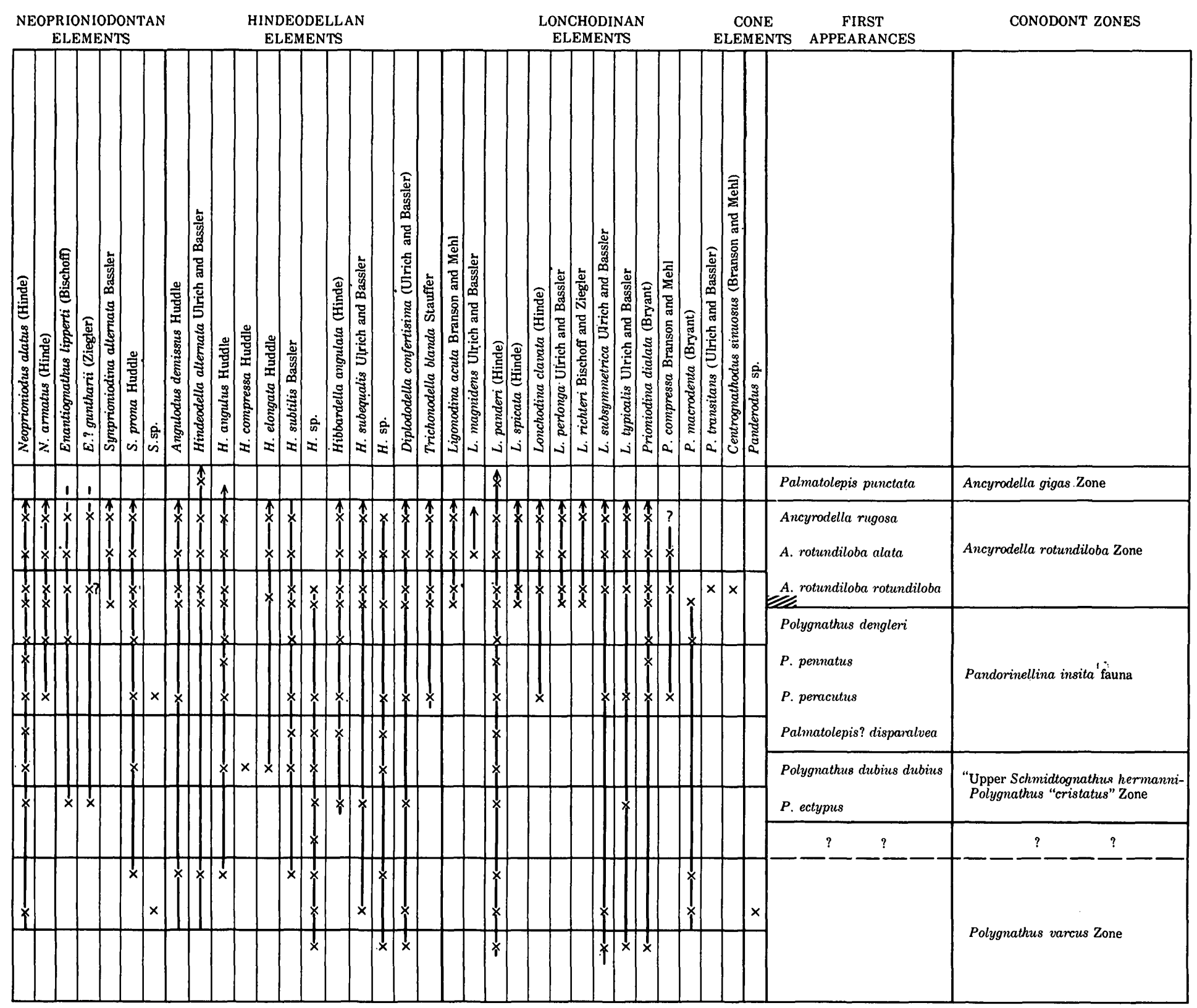


TABLE 3.-Occurrence, from west to east for each member, of conodonts in samples of the Windom Member of the Moscow Shale, and the Tully Limestone

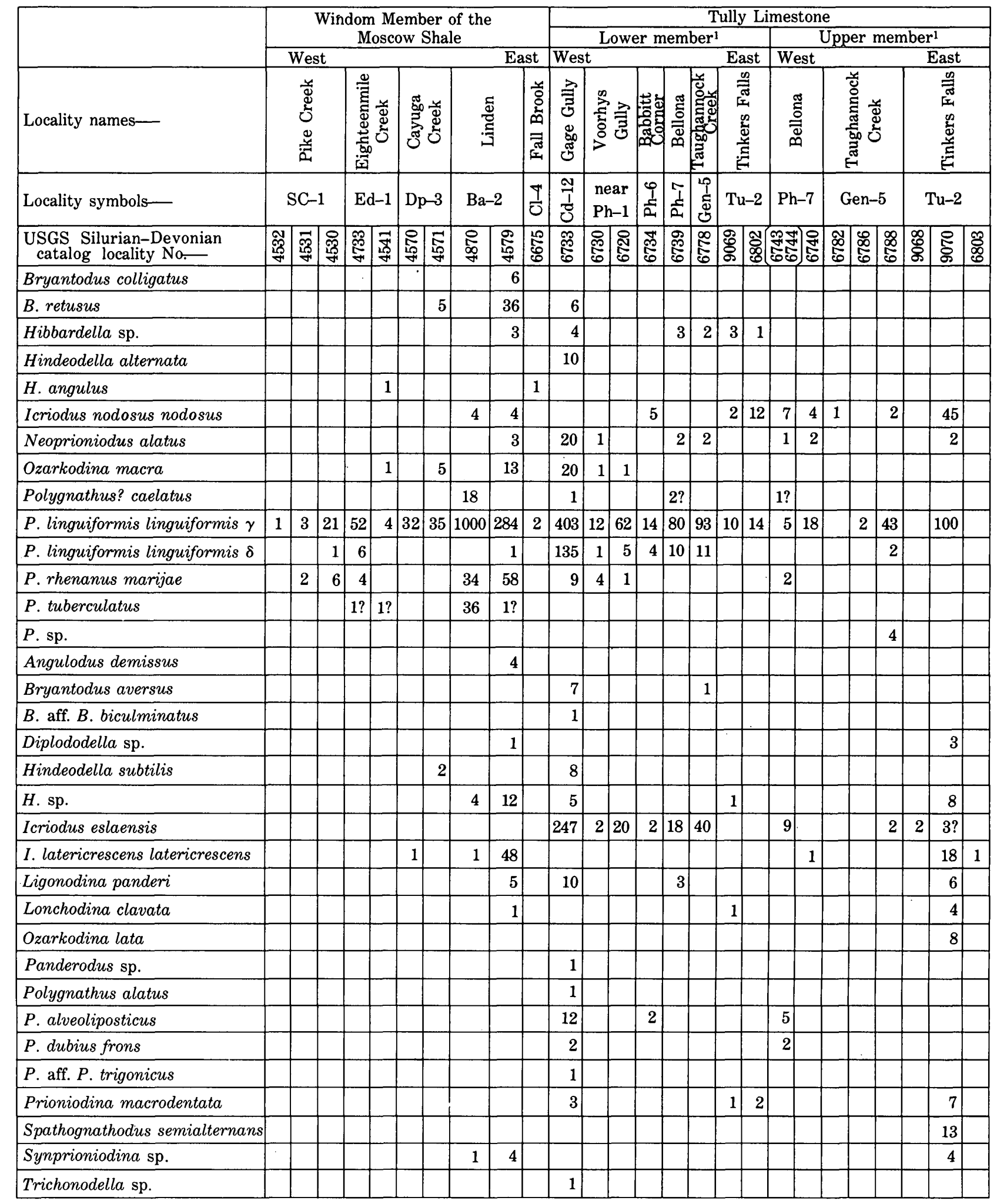

LLower and Upper Member of Heckel (1973). 
TABLE 4.-Occurrence, from west to east, of platform and blade conodonts in the Leicester Marcasite Member of Moscow Formation of Sutton (1951) and the North Evans Limestone of Rickard (1964)

\begin{tabular}{|c|c|c|c|c|c|c|c|c|c|c|c|c|c|c|c|c|c|c|c|c|}
\hline Locality name- & 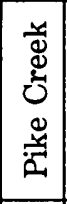 & \multicolumn{3}{|c|}{ 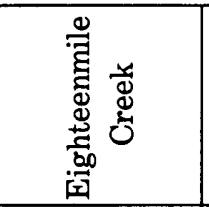 } & \multicolumn{2}{|c|}{ 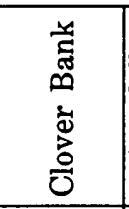 } & 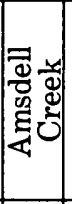 & \multicolumn{2}{|c|}{ 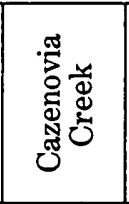 } & : & 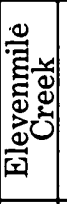 & 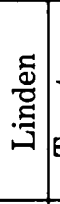 & 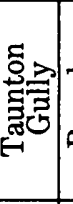 & 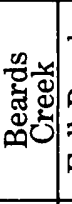 & 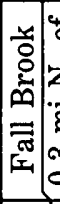 & 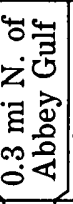 & 兘 & 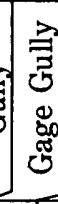 & $\begin{array}{l}3 \\
5 \\
5 \\
5 \\
5 \\
5 \\
5\end{array}$ & 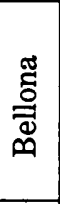 \\
\hline Locality symbol- & $\vec{\delta}$ & \multicolumn{3}{|c|}{ Ed-1 } & \multicolumn{2}{|c|}{$\mathrm{Ed}-2$} & 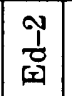 & \multicolumn{2}{|c|}{$\mathrm{Dp}-1$} & pa & $\begin{array}{l}3 \\
3 \\
4\end{array}$ & 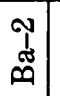 & $\frac{N}{U}$ & $\frac{p}{0}$ & $\frac{T^{\prime}}{0}$ & 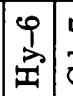 & $\frac{1}{\delta}$ & 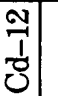 & \multicolumn{2}{|c|}{$\mathrm{Ph}-7$} \\
\hline $\begin{array}{l}\text { USGS Silurian-Devonian catalog } \\
\text { locality No- }\end{array}$ & 氶 & \begin{tabular}{l|l}
\multirow{3}{*}{} \\
హ్ \\
\end{tabular} & 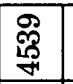 & $\underset{\substack{\mathfrak{N} \\
\infty}}{ }$ & $\begin{array}{l}0 \\
0 \\
0 \\
\end{array}$ & 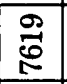 & कृ: & ญ్రి & 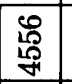 & $\begin{array}{l}8 \\
\text { 题 } \\
\end{array}$ & 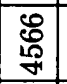 & 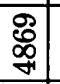 & 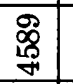 & 范 & 동 & 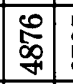 & 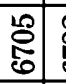 & กิโ & 蛋 & ్ㅡㅇ \\
\hline Ancyrodella rotundiloba rotundiloba & 44 & 40 & 5 & 110 & 6 & 27 & 18 & & & & & & & & & & & & & \\
\hline A. rotundiloba alata & 43 & 28 & 11 & 7 & & 58 & 9 & & & & & & & & & & & & & \\
\hline A. rugosa & & & & & & 5 & & & & & & & & & & & & & & \\
\hline Icriodus eslaensis & & 1 & 1 & & & & & & & & & & & & 1 & & & 6 & & \\
\hline I. latericrescens latericrescens & 3 & 2 & & 16 & & & 5 & 1 & & & & & & 6 & & & & & 9 & 11 \\
\hline I. nodosus nodosus & 7 & & 4 & & 3 & 37 & 52 & 160 & 31 & 70 & & 44 & $16 ?$ & 5 & & & 28 & & 44 & 400 \\
\hline I. sp. & & & & & & & & & & & & & & & 20 & 13 & & & & \\
\hline Palmatolepis? disparalvea & 3 & & & 17 & 2 & 8 & 4 & 20 & 3 & 11 & 4 & 2 & & & 3 & 3 & & & & \\
\hline Polygnathus alatus & 2 & & & 42 & 3 & 10 & 5 & & & & & & & & 2 & & & & & \\
\hline P. alveoliposticus & & & & & & & & 1 & & & & & & & & & & & & \\
\hline P. asymmetricus asymmetricus & & & & 2 & & & & & & & & & & & & & & & & \\
\hline P. asymmetricus ovalis & & & & 3 & & & 8 & & & & & & & & & & & & & \\
\hline P.? caelatus & 14 & 12 & 2 & 31 & 4 & 7 & 6 & 7 & & & & & & 2 & & 4 & & & & 1 \\
\hline P. collieri & 7 & & 3 & 42 & & 2 & & & & & & & & & & & & & & \\
\hline$P$. cristatus & 3 & 2 & & 10 & & & & & & & & & & & & & & & & \\
\hline P. dengleri & & & 1 & 40 & 2 & 44 & 11 & & & & & & & & & & & & & \\
\hline P. dubius dubius & 250 & 87 & 116 & 1700 & 90 & 500 & 290 & $90:$ & 240 & & 2 & & & 17 & 95 & \begin{tabular}{|l|l|}
49 & 3 \\
\end{tabular} & 34 & & & \\
\hline P. ectypus & & & 1 & 22 & & 8 & & 6 & 2 & 3 & & & & & 3 & & & & & 6 \\
\hline P. linguiformis linguiformis $\gamma$ & 560 & 465 & 77 & 1800 & 115 & 155 & 170 & 700 & 85 & 400 & 120 & 65 & 121 & 144 & 83 & 28 & 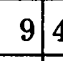 & 46 & 241 & 155 \\
\hline P. linguiformis linguiformis $\delta$ & 28 & 16 & 5 & 23 & 1 & 1 & 4 & 20 & 11 & 27 & & 2 & & 3 & & & & & & \\
\hline P. ordinatus & 9 & 12 & 3 & 100 & 3 & & 15 & 17 & 4 & 1 & & & & 6 & 3 & & & & & 4 \\
\hline P. pennatus & 67 & 50 & 43 & 950 & 36 & 150 & 180 & 13 & & 11 & & & & & & & & & & \\
\hline$P$. peracutus & 3 & & 2 & 8 & & & & 15 & 5 & 6 & 4 & 2 & & & & & & & & \\
\hline P. dubius frons & & & & & & & & & 92 & 145 & 27 & & & & & & & 70 & 824 & 400 \\
\hline$P$. rhenanus marijae & 7 & & 2 & 49 & 3 & 72 & 26 & 5 & & & & & & & & & & & & \\
\hline P. tuberculatus & 47 & 29 & 1 & 50 & 1 & & 5 & 8 & & 2 & & & & & & & & & & \\
\hline$P$. sp. of Ziegler, 1965 & 1 & & & 8 & & & & 17 & & 1 & & 2 & & & & & & & & \\
\hline Pseudopolygnathus & & & & & & & & 5 & & & & & & & & & & & & \\
\hline Spathognathodus sannemanni & & & & & & & & 1 & & 3 & & & & & & . & & & 3 & 9 \\
\hline S. aff. S. strigosus & & & & 2 & & 2 & 3 & & & & & & & & & & & & & 7 \\
\hline S. sp. & & & & & & 2 & & & & & & & & & & & & & & \\
\hline Underlying Formation & & $\begin{array}{l}\mathrm{SCO} \\
\text { indor }\end{array}$ & $\begin{array}{l}\text { W S. } \\
\text { m Me }\end{array}$ & $\begin{array}{l}\mathrm{HAL} \\
\text { embel }\end{array}$ & & & & & & & & & & & & & & & $\begin{array}{l}\text { JLL } \\
\text { owe } \\
\text { emb }\end{array}$ & $\begin{array}{l}\mathrm{Y} \\
\mathrm{r} \\
\mathrm{er}^{1}\end{array}$ \\
\hline
\end{tabular}

1Lower Member of Heckel (1973). 
Member of the Moscow Formation of Sutton (1951), and the Williams Brook Coquinite Member of the Ithaca facies of Caster (1933), all represent relatively high-energy environents in which conodonts were sorted and broken along with the other constituents of the rock. The Geneseo Shale and the Genundewa Limestone Members of the Genesee, with abundant styliolinids, probably were deposited in low-energy environments, and in these rocks the conodonts were not sorted. Concretions in lowenergy environments were diagenetic, and they enclosed conodonts and other fossils in the rock. Black shale units generally preserved a higher proportion of the thin bar units than did other rocks, and most of the conodont apparatuses (conodonts approximately in the living arrangement) discovered are in black shale. No apparatuses have been found in the Genesee Formation. Winnowed samples from high-energy environments do not provide satisfactory ratios of elements to determine multielement taxa. This is one of the reasons that multielement nomenclature is not used in this report.

It is often difficult to recognize reworked conodonts because they may show no sign of abrasion or discoloration. Even though the conodonts have not been moved very far, the variously shaped elements may be sorted. Some conodonts, especially Polygnathus linguiformis and Icriodus latericrescens in the Leicester Marcasite Member of Sutton (1951) and the North Evans Limestone of Rickard (1964), are abraded and discolored; they must have been reworked. Other specimens of the same species in the same beds are neither abraded nor discolored; they may or may not have been transported. The abundance of fish plates, phosphatic nodules, and small-scale crossbedding suggests that the North Evans Limestone is a lag concentrate.

Two block samples of the whole thickness of the North Evans Limestone of Rickard (1964) at Eighteenmile Creek (section 1, USGS 8123-SD) were collected to check the possibility that the bed represents a condensed section rather than a winnowed lag deposit. The blocks were sawed across the bedding and then along the bedding, as near as possible to an argillaceous parting. One block was divided into three vertical units and the other into four units. All the conodonts in the treated and picked samples were counted. No significant differences were found between conodont faunules from the bottom and top samples. The bed must have been a composite lag deposit completely mixed during occasional storms.
When Hass started this project, little was known of the conodont fauna of the Tully Limestone and Windom Member of the Moscow Shale. He, therefore, collected from these formations to determine what conodonts could be reworked from them into the Genesee Formation. These collections are included in this paper. Heckel (1973) demonstrated that the contact between the Moscow Shale and the Tully Limestone is a diastem west of Tully Valley and that a widespread erosion surface separates the "Lower and Upper Members" of the Tully Limestone. In the terminology proposed by Heckel (1973, p. 12-13 and fig. 4) for west-central New York, the Tully Limestone is divided into a "Lower Member" approximately equal to the Tinkers Falls and overlying Apulia Members of Cooper and Williams (1935), and an "Upper Member" nearly equivalent to the West Brook Member of Cooper and Williams.

West of Seneca Lake, the Geneseo Shale Member of the Genesee Formation rests on progressively older units of the Tully Limestone until the "Lower Member" of Heckel disappears at Gage Gully (Cd-12) on Canandaigua Lake. West of Canandaigua Lake the Geneseo Shale Member rests on progressively older units of the Moscow Shale of the Hamilton Group (G. A. Cooper, 1930). The transgressive nature of this erosional contact suggests that conodonts from the Tully Limestone and Windom Member of the Moscow Shale might be reworked in the Geneseo Shale Member. This is especially true of the pyritic, calcareous bed called the Leicester Marcasite Member of Moscow Formation of Sutton (1951) in places and the North Evans Limestone of Rickard (1964) at Eighteenmile Creek (Ed-1) and nearby sections.

Table 3 shows the abundance of conodonts in the samples from the Moscow Shale and Tully Limestone. In the "Lower Member" of the Tully Limestone, the forms of Polygnathus linguiformis are the most abundant conodonts. Members of the $P$. varcus group are moderately abundant, and Icriodus eslaensis, I. nodosus, and I. latericrescens latericresens are common. The most massive of these elements are $P$. linguiformis and $I$. latericrescens latericrescens; these are found in the basal beds of the Geneseo Shale Member, most frequently as abraded and discolored fragments. Fortunately, small fragments of these species can be identified. The other abundant and common elements are fragile, and their fragments cannot be identified. These forms include abraded fragments of $I$. eslaensis, I. nodosus, and members of the $P$. varcus group with the blade broken off. The fact that the abundant recog- 
nizable fragments from both the Tully Limestone and the Moscow Shale are the same species means that both are to be expected and both occur in the basal Geneseo Shale Member regardless of the underlying formation.

Davis (1966) pointed out that conodonts are most abundant in the Tully Limestone in the lag and reworked beds near the base of the "Lower Member" and just above the disconformity at the base of the Upper Member.

\section{FACIES DISTRIBUTION}

The idea that many conodont species are restricted to particular facies and that some forms were restricted in their depth range is gaining acceptance. Davis (1966) found that in the Tully Limestone, Icriodus is most abundant in the argillaceous facies and Polygnathus is most abundant in the more calcareous facies. This distribution could be explained if Icriodus was pelagic in surface waters, whereas Polygnathus occupied a deeper water pelagic zone. An alternate explanation is that Icriodus liked muddy water. Samples from the Windom Member of the Moscow Shale came only from calcareous beds and therefore do not contribute to comparison of facies. The distribution of Icriodus in the Genesee Formation does not seem to match the pattern in the Tully Limestone. Icriodus is abundant in the Genundewa Limestone Member, but rare in the shale of the Genesee Formation.

\section{BIOSTRATIGRAPHY}

The general biosratigraphy of the Devonian rocks of New York has been summarized by Rickard (1964) and by Oliver and others (1969). The ammonoid zonation is based largely on the work of House $(1962,1965,1966,1967)$ and Kirchgasser (1974). The conodont zonation was discussed by Klapper and others (1971). For the discussion of age of certain stratigraphic units, the ammonoid and conodont zonations need consideration here.

\section{AMMONOID ZONATION}

In table 5, the European zonation is compared with the New York zonation on the basis of the work of M. R. House. Some of the samples for conodonts were taken from the same beds that House collected for ammonoids, so the two zonations are closely correlated at certain points. Kirchgasser (1974) proposed a more detailed zonation based on the sequence of species of Probeloceras in the Genesee, Sonyea, and lower West Falls Formation.

\begin{tabular}{|c|c|c|c|}
\hline \multirow[t]{2}{*}{ TABLE } & 5.-Early & $\begin{array}{l}\text { Late Devon } \\
\text { Europe and } \\
\text { [Modified from }\end{array}$ & $\begin{array}{l}\text { nian ammonoid zonation } \\
\text { New York } \\
\text { House, 1967] }\end{array}$ \\
\hline & \multicolumn{2}{|c|}{ European zones } & New York zones \\
\hline \multirow{3}{*}{ 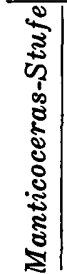 } & \multicolumn{2}{|c|}{ Crickites holzapfeli } & Manticoceras cataphractum \\
\hline & \multicolumn{2}{|c|}{ Manticoceras cordatum } & $\begin{array}{l}\text { Manticoceras rhynchostoma } \\
\text { Probeloceras lutheri } \\
\text { Manticoceras styliophilum }\end{array}$ \\
\hline & \multicolumn{2}{|c|}{ Pharciceras lunulicosta } & $\begin{array}{l}\text { Ponticeras perlatum } \\
\text { Pharciceras amplexum }\end{array}$ \\
\hline
\end{tabular}

Pharciceras amplexum is found in the "Upper Member" of the Tully Limestone at several localities. The appearance of this genus is commonly taken as the base of the Frasnian in Europe. Ponticeras perlatum first appears in the Geneseo Shale Member of the Genesee Formation and also occurs in the lower part of the Penn Yan Shale Member of the Genesee (including the Lodi Limestone of Clarke, in Lincoln, 1895) and in the Sherburne Flagstone Member of the Genesee. In the upper part of the Penn Yan Shale Member in the Genesee Valley, forms tentatively referred to Koenentites and Probeloceras are found above the highest beds with Ponticeras; Manticoceras is believed to enter still higher, near the top of the Penn Yan Shale Member (M. R. House and W. T. Kirchgasser, written commun., 1974).

Manticoceras styliophilum is the common manticoceratid in the Genundewa Limestone Member. This member also carries Probeloceras genundewa. Kirchgasser (1974) reported a new species of Probeloceras in the West River Shale Member of the Genesee and the entry of Probeloceras lutheri s.s. above the Genesee Formation in the lower part of the Cashaqua Shale Member of the Sonyea Formation.

\section{CONODONT ZONATION}

The conodont zones near the Middle-Upper Devonian boundary were first proposed in the Rhenish Slate Mountains of Germany and, subsequently, were applied worldwide. The European zonation was established and summarized by Ziegler (1962, 1965b, 1971). It is based on ranges of conodont element species in relatively thin, condensed calcareous sections and has been widely used with little critical evaluation. In summarizing the Devonian conodont zonation for North America, Klapper and others (1971) could not match the European range zones and instead used assemblage zones. The two zonation systems are compared in table 6. 
TABLE 6.-Comparison of European and North American conodont zonation

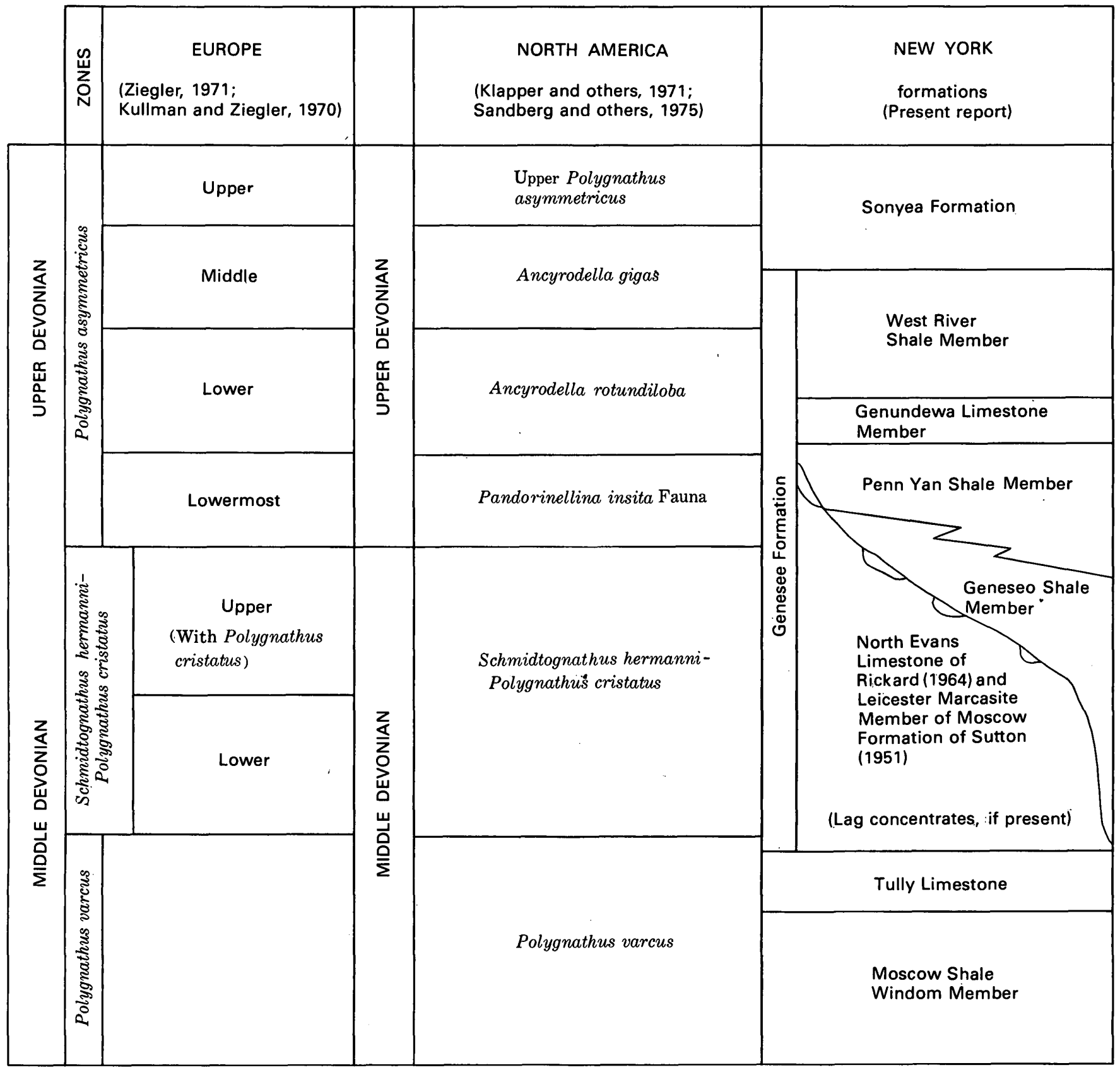


The differences between the two zone schemes are partly in the names selected, but these dissimilarities also reflect real or apparent differences in ranges in Europe and North America and possibly differences in facies. The principal difficulties are near the Middle and Upper Devonian boundary, especially in reef and nonreef facies. The thick clastic section in western New York provides an opportunity to check the ranges of some of the critical species involved in the different zone schemes.

There are difficulties in using the New York sections to check conodont ranges. The collecting of conodonts is more difficult from clastic sections than from calcareous sections, and much of the New York section has not yielded conodonts. Some collections contain only broken specimens, few of which are identifiable. The true range of a fragile form-species is difficult to establish. The European zones are based on pelagic facies, and the effect of facies has not been considered in extending the standard zonation. Probably the clastic facies of the New York section has affected the distribution of some of the critical species used for the standard zonation.

The Middle-Upper Devonian boundary is not indicated on table 6 because the series boundary is not established in the European standard sections. This problem has been discussed recently in detail by House (1973) and by Mouravieff and Bouckaert (1973). Figure 1 shows the stratigraphy and conodont zonation in the Belgian stratotype section. Note that the $P$. varcus Zone continues into the lower Frasnian in this interpretation. The International Geological Congress Subcommission will have to establish this boundary on a worldwide basis. In the meantime, arguments over the position of the Middle-Upper Devonian boundary in New York are nonproductive.

\section{POLYGNATHUS VARCUS ZONE}

As defined by Ziegler (1971), the Polygnathus varcus Zone in Europe is late Givetian in age; it coincides with the upper part of the range of Maenioceras terebratum and species of Agoniatites. Ziegler drew the lower boundary at the first abundance of $P$. varcus, $P$. beckmanni, and Spathognathodus brevis; he drew the upper boundary at the first appearance of Schmidtognathus hermanni. Ziegler did not change his definition of the $P$. varcus Zone, but the upper limit is confused by his statement (1971, chart 2) that $P$. latifossatus Wirth is juvenile $S$. hermanni, because $P$. latifossatus occurs in the uppermost part of the $P$. varcus Zone

\begin{tabular}{|c|c|c|c|c|}
\hline & LITHOSTF & ATIGRAPHY & CONODO & ZONATION \\
\hline & FRASNIAN & STRATOTYPE & $\begin{array}{l}\text { BELGIUM } \\
\text { Reef facies }\end{array}$ & $\begin{array}{c}\text { GERMANY } \\
\text { Pelagic facies }\end{array}$ \\
\hline & $\begin{array}{l}\text { FAM } \\
\text { A. de }\end{array}$ & $\begin{array}{l}\text { NNIAN } \\
\text { enzeilles }\end{array}$ & MiddI & riangularis \\
\hline & & & Lower & iangularis \\
\hline & 䍃竞离 & $\begin{array}{c}\text { upper } \\
\text { F3 b b }\end{array}$ & $\begin{array}{l}\text { Upper gigas } \\
\text { sensu lato }\end{array}$ & $\begin{array}{l}\text { Uppermost gigas } \\
\text { Upper gigas }\end{array}$ \\
\hline$z$ & 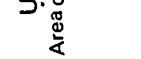 & $\begin{array}{l}\text { Low } \\
\text { F3 b }\end{array}$ & A.triangularis & Lower gigas \\
\hline 8 & ש & i $1 / / 8 \mathrm{Bi}$ & & A. triangularis \\
\hline$z$ & 山岂总 & 9 Bioher & Upper & immetricus \\
\hline es & 을 & Bioner & Middle & (m. (A. gigas) \\
\hline$<$ & 离 & $\frac{c}{\frac{b}{a}}$ & Lower & mmetricus \\
\hline$\propto$ & & c & & Lowermost asym. \\
\hline 4 & 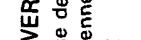 & $T_{1}^{1}$ & asymmetricus) & Upper $h$-cristat \\
\hline & 9 尊 & & & Lower $h$-cristat \\
\hline & $\begin{array}{l}\text { GI } \\
\text { de Givet. To }\end{array}$ & TIAN & & varcus \\
\hline
\end{tabular}

Figure 1.-Stratigraphy and conodont zonation of the Belgian Frasnian stratotype section. Modified from Mouravieff and Bouckaert (1973).

(Ziegler, 1971, p. 259). Ziegler (oral commun., 1974) said that by "juvenile" on his chart 2 he meant "ancestor."

In Europe, Icriodus latericrescens latericrescens has a restricted range within the $P$. varcus Zone, but in New York, it ranges through the whole $P$. varcus Zone and into the Ancyrodella rotundiloba Zone, from the Centerfield Limestone Member of the Ludlowville Formation to the Genundewa Limestone Member of the Genesee Formation. Furthermore, the taxonomic revision of the $P$. varcus species complex by Klapper, Philip, and Jackson (1970) requires that published ranges of $P$. varcus be reexamined. Large collections of these delicate species are rare, and many specimens of the species complex cannot be identified without perfect preservation. In western New York, $P$. varcus s.s. ranges from the Tully Limestone to the Genundewa Limestone Member of the Genesee Formation and thus continues into the Ancyrodella rotundiloba Zone. Clearly, the definition of the zone as used in Europe is not applicable in western New York.

In North America, Klapper and others (1971) recognized the $P$. varcus Zone by the association of $P$. varcus, Icriodus latericrescens latericrescens, and Polygnathus linguiformis linguiformis. This defini- 
tion was used to limit the zone in New York from the Centerfield Limestone Member of the Ludlowville Formation to the top of the Tully Limestone. Elsewhere, it was recognized in the Traverse Group in Michigan, the Beechwood Limestone Member of the Sellersburg Limestone and North Vernon Limestone of Borden (1876) in Indiana, the Lingle Limestone in Illinois, the lower Cedar Valley Limestone in Missouri, and all but the uppermost beds of the Cedar Valley Limestone of Iowa.

\section{SCHMIDTOGNATHUS HERMANNI-POLYGNATHUS CRISTATUS ZONE}

The original definition of this zone by. Ziegler (1965b, p. 656) included the range of Schmidtognathus hermanni and Polygnathus cristatus, before the appearance of Polygnathus asymmetricus ovalis. Ziegler divided it into a lower part containing $S$. hermanni and an upper part containing Polygnathus cristatus, S. pietzneri, S. wittekindti, Polygnathus pennatus, $P$. ordinatus, and $P$. n. sp. Ziegler, $1965 \mathrm{~b}$. Klapper and others $(1971$, p. 299) recognized the $S$. hermanni-P. cristatus Zone, interpreted as "possibly the lower part below $P$. cristatus" in the uppermost Solon and lower Rapid Members of the Cedar Valley Limestone in Iowa. The species they reported from this stratigraphic level are those Ziegler (1965b) reported from the upper part of the zone containing $P$. cristatus, except that $P$. cristatus is not present. The $S$. hermanni-P. cristatus Zone was reported to be present in the Great Basin, in the Cedar Valley Limestone of Missouri, in southern Illinois, and in the basal New Albany Shale in Indiana. Klapper and others (1971) reported that the associated megafossils indicated that these beds should be referred to the Middle Devonian. $S$. hermanni has not yet been reported from the United States, and the boundary between the $P$. varcus and $S$. hermanni-P. cristatus Zones is not clear.

\section{POLYGNATHUS ASYMMETRICUS ZONE}

In 1971, Ziegler recognized the following formal subdivisions of the $P$. asymmetricus Zone: Lowermost, Lower, Middle, and Upper. The Lowermost was defined as the occurrence of $P$. asymmetricus before Ancyrodella rotundiloba appears. The Lower was based on the joint occurrence of $P$. asymmetricus and Ancyrodella rotundiloba, and the Middle was based on the appearance of Palmatolepis punctata. The Upper was defined (Ziegler, 1962) as the zone of occurrence of $P$. asymmetricus and Palmatolepis punctata without Ancyrodella rotundiloba.
The known occurrences in New York do not fit this zonal scheme precisely, as shown in the following discussion.

For North America, Klapper and others (1971) proposed a special zonation in that they introduced the Spathognathodus insitus Fauna (now Pandorinellina insita Fauna because of taxonomic revision), which is approximately equivalent to the Lowermost $P$. asymmetricus Zone, is dominated by $P$. insita, and is below the first appearance of $A n$ cyrodella rotundiloba. $P$. insita is not confined to the "Fauna," and it ocurs with Palmatolepis punctata in the lower part of the Snyder Creek Shale in Missouri and in Ancyrognathus triangularis Zone in Iowa. $P$. insita occurs in the Williams Brook Coquinite Member of the Ithaca facies of Caster (1933), and in the Marathon Sandstone Member of Ithaca facies of Caster (1933) of the Genesee Formation, but the "Fauna" is probably present lower in the Genesee Formation.

Above the $P$. insita Fauna, Klapper and others (1971, fig. 3) used the Ancyrodella rotundiloba Zone, which they considered as approximately equal to the Lower asymmetricus Zone of Ziegler. Above the $A$. rotundiloba Zone, Klapper and others (1971) used the $A$. gigas Zone, approximately equal to the Middle asymmetricus Zone of Ziegler. The latter zone is based on the first appearance of $A$. gigas, which agrees with the European zonation. Above the Ancyrodella gigas Zone, Klapper and others used the Upper Polygnathus asymmetricus Zone of Ziegler's European zonation.

\section{PROBLEMS IN USING THE EUROPEAN RANGE ZONES IN WESTERN NEW YORK}

The boundary between the $P$. varcus and Schmidtognathus hermanni-Polygnathus cristatus Zones in the European conodont zonation is drawn at the first appearance of $S$. hermanni. This species has not been found in New York; consequently, the boundary in New York cannot be recognized. The ranges of other species in the $S$. hermanni-P. cristatus Zone in Europe do not seem to be the same as those in New York. This fact complicates the recognition of the limits of the $P$. varcus, $S$. hermanni$P$. cristatus, and the Polygnathus asymmetricus Zones. Other problems include those caused by revisions in taxonomy and nomenclature, such as those involving $P$. varcus and $P$. cristatus, and the fact that some species used in zonation are facies limited.

As pointed out previously, the Polygnathus varcus species complex has been redefined by Klapper, Philip, and Jackson (1970), but the ranges of the 
individual species have not been established. The records of the species occurrence are in doubt until the specimens involved or topotype material is restudied in light of the taxonomic revision and refined sampling.

Polygnathus dubius and $P$. decorosus are other species than cannot be used for zonation without restudy. The species group that includes Polygnathus beckmanni, $P$. caelatus, and $P$. variabilis is also in need of revision. In this group there is the strong possibility that the immature, mature, and gerontic specimens are quite different.

The species commonly called Polygnathus cristatus is, in my opinion, not $P$. cristatus of Hinde, and should be referred to $P$. ectypus Huddle, as suggested by Kirchgasser (1970). This interpretation, along with the local occurrence of Schimdtognathus hermanni, suggests that the zone, or zones, between the $P$. varcus Zone and the Ancyrodella rotundiloba Zone needs a new name as well as a new definition.

How much of the difference between the European and North American zonation schemes is due to facies is unknown. Some species of Icriodus seem to have been confined to surface layers or perhaps to shallow waters and are common in high-energy deposits. This may explain the long range of Icriodus latericrescens latericrescens in the United States and the short range in Europe. On the other hand, some species of the form genus "Spathognathodus" also may be shallow-water forms, but "S." planus and "S." brevis, common in the European deeper water facies $P$. varcus Zone, are rare in New York. Davis (1966) showed that the Icriodus-Polygnathus ratio in the Tully Limestone varies directly with the insoluble residue. Some species of Icriodus seemingly preferred turbid water or at least tolerated it.

\section{SEQUENCE OF FIRST APPEARANCES IN THE} NEW YORK GENESEE FORMATION

The following species first appear in the base of the onlapping Genesee Formation in sequence, oldest to youngest, westward from Cayuga Lake to Eighteenmile Creek (see table 1; pl. 32): (1) Polygnathus ectypus and $P$. ordinatus; (2) $P$. dubius; (3) Palmatolepis? disparalvea; (4) Polygnathus peracutus; (5) P. pennatus; (6) P. dengleri; (7) P. asymmetricus, Ancyrodella rotundiloba, and $P$. cristatus. This sequence is confirmed, in general, by the appearance of these species in the same order upward in the sections, but most of the sequence of species occurs in the Geneseo Shale Member (black shale) from which there are very few samples. The sequence at the base is partly confirmed at Menteth Gully (Cd-7) (see de Witt and Colton, 1978 , pls. 2 and 3 ) and is suggested in other sections. I am not certain about the position in the sequence of Palmatolepis? disparalvea and Polygnathus asymmetricus because these species are rare. Examination of table 1 shows that many new forms, including Polygnathus ectypus, $P$. dubius, $P$. dengleri, and $P$. pennatus, appear together near the base of the Penn Yan Shale Member in the Lodi Limestone of Clarke (in Lincoln, 1895) or "False Genundewa Limestone." These calcareous, argillaceous, silty limestones and gray shales represent a considerable change in facies from the underlying black shale of the Geneseo Shale Member. Westward, this change in facies takes place progressively nearer the base of the formation, and the Geneseo disappears west of Cayuga Creek (Dp-3) (pl. 2, de Witt and Colton, 1978). Perhaps the appearance of these forms is in part related to the change from the black shale to gray shale facies. My collections are sufficiently numerous to show that Ancyrodella rotundiloba rotundiloba and $A$. rotundiloba alata occur below the Genundewa Limestone Member at Menteth Gully (Cd-7), and House (1967, p. 1065) reported Manticoceras 13 feet below the Genundewa at Hemlock Outlet (Hy-2). W. T. Kirchgasser (written commun., 1974) pointed out that Ancyrodella rotundiloba occurs 16 feet above the base of the Penn Yan Shale Member at Menteth Gully (Cd-7), well below the probable first appearance of Manticoceras. The collections from Taunton Gully (Cl-2) indicate that $A$. rotundiloba first appears with the ammonoid that House and Kirchgasser referred to Koenenites and after the first appearance of Ponticeras (Ponticeras is Late Devonian in the ammonoid chronology). These beds are certainly Late Devonian in age. The sequence at Menteth Gully $(\mathrm{Cd}-7)$ clearly shows that $P$. pennatus becomes abundant later than $P$. dubius and $P$. peracutus.

Clearly, at least three faunas are present in the Genesee Formation below the West River Shale Member: (1) a pre-P. ectypus fauna; (2) the $P$. ectypus, Palmatolepis? disparalvea, Polygnathus dubius, $P$. peracutus fauna; and (3) the Ancyrodella rotundiloba fauna.

The staggered appearance of the conodont species in the base of the Genesee Formation is thought to be due to marine transgression northwestward onto the southeastern flank of the Algonquin arch. This overlap was pointed out by Hass in 1959, and he recognized a pre-Genundewa conodont fauna characterized by Polygnathus pennatus (now P. dubius) 
equivalent to the pre- $P$. ectypus fauna listed above, and a Genundewa fauna characterized by Ancyrodella rotundiloba.

\section{APPLICATION OF CONODONT ZONATION TO NEW YORK FORMATIONS}

AGE OF THE WINDOM MEMBER OF THE MOSCOW SHALE AND THE TULLY LIMESTONE

There is no reason to question the assignment of the Windom Member of the Moscow Shale and the Tully Limestone to the Polygnathus varcus Zone, but the principal evidence is stratigraphic position, because all or nearly all of the conodont species range upward into the overlying zones. The lack of other species of Polygnathus, especially broad platform species, also indicates assignment to the $P$. varcus Zone. Table 3 shows, from 26 samples, the abundance and range of conodont species in the Windom Member of the Moscow and in the Tully Limestone. Polygnathus linguiformis linguiformis is the only abundant species in the two formations. Members of the Polygnathus varcus group are rare, and species of Icriodus are locally abundant.

The fauna of the "Lower Member" of Heckel (1973) of the Tully Limestone is characterized by an abundance of $P$. linguiformis form delta, $P$. alveoliposticus and Icriodus eslaensis. These taxa and others range upward into the Genesee Formation. Noteworthy is the occurrence of Spathognathodus planus only in the "Upper Member" of the Tully Limestone of Heckel (1973), presumably in the upper part of the Polygnathus varcus Zone, whereas in Europe, this species is abundant in the lower part. Wittekindt (1965) reported Polygnathus bryanti (= $P$. tuberculatus) in the upper part of the varcus Zone in Germany. In New York, this species has been found in the Windom Member of the Moscow Shale and in the Genesee Formation as high as the Genundewa Limestone Member, but not in the intervening Tully Limestone.

Davis (1966, p. 1510B) reported a mixed "Upper and Lower Members" (Heckel, 1973) Tully fauna in the westernmost outcrops. The mixing of faunas is not confirmed by samples from the westernmost exposure at Gage Gully ( $\mathrm{Cd}-12)$; these samples have a "Lower Member" of the Tully conodont fauna and also the brachiopod Hypothyridina venustula. These data confirm Heckel's (1973, p. 26) statement that the only Tully Limestone bed present at Gage Gully is the Carpenter Falls bed of the "Lower Member" of the Tully Limestone.
AGE OF THE GENESEO SHALE MEMBER AND ASSOCIATED BEDS OF THE GENESEE FORMATION

The Genesee Formation rests conformably on and appears to interfinger with the Tully Limestone near Cayuga Lake and eastward. Westward from Cayuga Lake, however, the contact is disconformable, and the Geneseo rests on progressively older beds of the Tully Limestone and older Moscow Shale, overlapping and transgressing the southeastern flank of the Algonquin arch. Local lenses of pyritic and calcareous sandstone, called the Leicester Marcasite Member of the Moscow Formation of Sutton (1951) west of Gage Gully (Cd-12) and called the North Evans Limestone of Rickard (1964) at Eighteenmile Creek, are present at the base of the Genesee Formation and are as much as 0.5 of a foot thick. These lenticular beds are interpreted here as lag concentrates deposited in the transgressing Genesee sea. The sands were sorted, crossbedded, and too limited in quantity to form a continuous blanket of sandstone. Probably they were deposited as calcareous sandstone and became pyritized after they were buried by the black mud of the overlying Geneseo Shale Member. The North Evans Limestone probably escaped pyritization because it was overlain by calcareous gray mud, rather than by black mud. The succession of conodont species appearing in these basal beds indicates this transgression. As shown by plate 2, de Witt and Colton (1978), the Geneseo Shale Member pinches out near Cayuga Creek (Dp-3), and to the west, the Penn Yan Shale Member overlies the Leicester Marcasite Member of the Moscow Formation of Sutton (1951) or the North Evans Limestone of Rickard (1964).

The oldest conodont collections from the base of the Geneseo Shale Member are those from Taughannock Creek in Taughannock Falls State Park (Gen-5) (table 1 and pl. 3 of de Witt and Colton, 1978). There the collection contains Icriodus eslaensis, I. nodosus nodosus, and Polygnathus dubius frons? The $P$. dubius frons? might be referred to $P$. dubius dubius, but the position of the basal cavity, the blade, and pseudorostrum look more like $P . d u$ bius frons. The specimens, though numerous, are broken and dirty; consequently, the identification is questionable. This fauna appears to be older than that found at Kashong Creek west of Bellona $(\mathrm{Ph}-7)$, where Polygnathus ectypus and $P$. ordinatus are present in the basal bed, here called Leicester Marcasite Member of Sutton (1951). The occurrence of conodonts in the Leicester Marcasite Member is shown in figure 2 and table 4. At Bellona, Icriodus is common; this abundance probably indi- 
cates shallow water. Polygnathus dubius dubius first appears in the basal beds about 20 miles west of Bellona at Menteth Gully (Cd-7). Palmatolepis? disparalvea first appears still farther west at the section 0.3 mile north of Abbey Gulf ( $\mathrm{Hy}-6)$ a tributary of Honeoye Creek; at Cayuga Creek (Dp-3), Palmatolepis? disparalvea, Polygnathus pennatus, and $P$. peracutus are present. Thus, in terms of the conodont zonation, the age of the basal beds of the Geneseo Shale Member ranges from the upper part of the Polygnathus varcus Zone at Taughannock Falls to at least the "Schmidtognathus hermanniPolygnathus cristatus" Zone or perhaps the Pandorinella insita Fauna.

From Cazenovia Creek (Dp-1) west to the mouth of Pike Creek (Sc-1), where the Genesee Formation goes below the level of Lake Erie, the discontinuous lenses of the Leicester Marcasite Member of the Moscow Formation and the North Evans Limestone are at the base of the Penn Yan Shale Member and range in age from the $P$. insita Fauna to the Ancyrodella rotundiloba Fauna.

House $(1967$, p. 1065) reported a species of Tornoceras from the Leicester Marcasite Member of the Moscow Formation of Sutton (1951) at Gorham, N.Y. (near Bellona $\mathrm{Ph}-7$ ), and placed the bed in the Pharciceras lunulicosta Zone (table 1) or Frasnian. He also recorded ponticeratids in the Geneseo Shale Member. They are also present in the overlying Penn Yan Shale Member and in the equivalent Sherburne Flagstone Member. House placed these units in the Frasnian.

\section{AGE OF THE PENN YAN SHALE MEMBER OF THE} GENESEE FORMATION

In the area between Cayuga Lake and Seneca Lake, the lower part of the Penn Yan Shale Member is conspicuously calcareous, and the shale and siltstone are fossiliferous. A bed about 5 feet above the base of the Penn Yan Shale Member at Mill Creek was named Lodi Limestone by Clarke (footnote in Lincoln, 1895, p. 100-101). It has also been mistakenly correlated with the Genundewa Limestone Member (see de Witt and Colton, 1978) and has been called informally the "False Genundewa Limestone" by some authors. The Lodi Limestone of Clarke (in Lincoln, 1895) contains a conodont fauna including Polygnathus dubius dubius, $P$. dengleri, $P$. ectypus, and $P$. pennatus; it is clearly older than the Ancyrodella rotundiloba Zone and about equivalent to the Lowermost, or Lower Polygnathus asymmetricus Zone of Europe, although $P$. asym- metricus has not been found in Clarke's Lodi Limestone.

The change in facies from the black shale of the Geneseo Shale Member to the calcareous gray shale and siltstone of the Penn Yan Shale Member probably affected the distribution of conodonts. Conodonts are more abundant in the Penn Yan Shale Member and are more easily recovered.

House (1967, p. 1065) reported abundant ponticeratids in the Lodi Limestone of Clarke (in Lincoln, 1895) and placed the unit in the Ponticeras perlatum Zone which correlates with part of the Pharciceras lunulicosta Zone of the early Frasnian Age. J. G. Johnson (written commun., Dec. 16, 1968) reported the brachiopod Leiorhynchus quadracostatus and suggested that this brachiopod was not younger than the Schmidtognathus hermanni-Polygnathus cristatus Zone. This age assignment does not agree with the conodont fauna of Clarke's Lodi Limestone.

Westward from Cayuga Lake, the lower part of the Penn Yan Shale Member contains the same conodonts as Clarke's Lodi Limestone, and there is no evidence that east of Eighteenmile Creek the member is any younger than the Lodi. At Eighteenmile Creek a thin unit, referred to the Penn Yan Shale Member, contains Ancryodella rotundiloba and is placed in the Ancyrodella rotundiloba Zone (or Lower P. asymmetricus Zone). The upper part of the Penn Yan also belongs in the Ancyrodella rotundiloba Zone. This species first appears 30 feet below the Genundewa Limestone Member at Menteth Gully (Cd-7).

Clarke's Lodi Limestone has been recognized by L. V. Rickard (oral commun., 1974) and by Kirchgasser (1974) in the subsurface in the lower part of the Penn Yan Shale Member as far west as the meridian of White Creek. It was found at localities Gen-4, Gen-2, Ov-10, Ov-12, Wg-3, At-1, and $\mathrm{Dp}-3$.

\section{AGE OF THE WILLIAMS BROOK COQUINITE MEMBER} OF ITHACA FACIES OF CASTER (1933)

The conodont fauna of the Williams Brook Coquinite Member of the Ithaca facies at Williams Brook (I-2) is dominated by Icriodus and includes a few specimens of Polygnathus and "Spathognathodus." The physical characters of the crossbedded sandy, silty coquinite, and the abundance of Icriodus suggest that the rock was deposited in shallow water with relatively high energy. It represents a different facies from the Genundewa Limestone Member, and somewhat different facies from the Crosby Sandstone Member of the Standish Forma- 
tion of Torrey and others (1932). The absence of Ancyrodella rotundiloba suggests that the Williams Brook is as old as the Pandorinellina insita Fauna and much older than the Genundewa Limestone Member and Crosby Sandstone Member. However, the faunal difference may be due to facies, rather than age.

\section{AGE OF THE GENUNDEWA LIMESTONE MEMBER OF THE GENESEE FORMATION}

The conodont fauna of the Genundewa Member is characterized by conodonts that have thick, heavy platforms, like Ancyrodella rotundiloba, Polygnathus cristatus, and $P$. collieri. Some of the bar types, including Bryantodus retusus, $B$. collingatus, and species of Prioniodina and Lonchodina, are also thick and heavy. In addition to these forms, lighter, thinner forms probably belong to two or three multielement species. The Genundewa is clearly within the Ancyrodella rotundiloba Zone, but the zone extends above and below the Genundewa Limestone Member.

House $(1967$, p. 1065) placed the upper part of the Penn Yan Shale Member and the Genundewa Limestone Member in the Manticoceras styliophilum Zone and suggested that the overlying West River Shale Member might belong in another subzone. The ammonoid fauna of the West River Shale Member is poorly known, according to W. T. Kirchgasser (written commun., 1974), and at present is distinguished by a new species of Probeloceras similar to $P$. genundewa of the Genundewa Limestone Member.

\section{AGE OF THE CROSBY SANDSTONE MEMBER OF THE STANDISH FORMATION AS USED BY TORREY AND OTHERS (1932)}

De Witt and Colton (1978) traced the Genundewa Limestone Member into the Crosby Sandstone Member, and W. H. Hass recognized that the faunas of the two units were the same. As shown on table 1, the faunas of both units are referred to the Ancyrodella rotundiloba Zone, but this Zone includes rocks above and below the two units. The conodont evidence is compatible with the physical stratigraphy but cannot precisely confirm it.

\section{AGE OF THE WEST RIVER SHALE MEMBER OF THE GENESEE FORMATION}

The lower part of the West River Shale Member contains abundant Ancyrodella rotundiloba and is placed in the $A$. rotundiloba Zone. Upward in the member, $A$. rotundiloba is replaced by $A$. rugosa. The latter species includes many individuals that have regular ornamentation like $A$. gigas and that seem to be transitional between $A$. rotundiloba and $A$. gigas, but all are assigned to $A$. rugosa because of the lack of keels and to the $A$. rotundiloba Zone. At Wilder Run at Bristol Center (Cd-5), a single specimen, referred to Palmatolepis punctata, occurs about 14 feet below the top of the West River Shale Member. Probably the upper part of the member is in the Ancyrodella gigas Zone.

\section{SYSTEMATIC PALEONTOLOGY OF CONODONTS}

\section{MULTIELEMENT VERSUS ELEMENT TAXONOMY}

Traditionally, each conodont element has been named and described as if it were the only element that belonged to a biologic species. Gradually conodont students recognized that the individual conodont elements belonging to an apparatus could include several conodont form-taxa. Evidence accumulated that platforms, bars, and blades all occurred in the same apparatus of an animal. Thus, some of the older single-element, or form, taxonomy is incorrect biologically. This conclusion was strengthened by the 1971 "Symposium on Conodont Taxonomy" (Lindström and Ziegler, 1972). (For the history of conodont taxonomy, see Huddle, 1972.) The participants in the symposium agreed that every effort should be made to establish an apparatus (multielement) taxonomy. It was recognized that many individual elements could not be assigned to an apparatus, and that the recognition of apparatus genera and species based on discrete conodont elements would be difficult and subject to alternate interpretations. Form taxonomy will continue for elements not assignable to apparatuses and for elements whose association with apparatuses is questionable.

The criteria for the recognition of the element content of multielement apparatuses range in probability from unquestionable well-preserved assemblages lying in approximate life position to apparatuses based on the common association and range of disjunct elements. Conodonts are normally prepared for study by breaking up or dissolving the rock, and only separate elements are available for study. Thus, except for the relatively rare assemblages that represent assured apparatuses, all apparatus taxa are interpretive. Various criteria are used for selecting the elements assigned to a particular apparatus taxon. Some elements are fused into clusters, and these are thought to be part of an apparatus, but the discrete elements offer a more difficult problem. Walliser (1964) used large collec- 
tions to recognize apparatuses of isolated Silurian conodont elements on the basis of common association in samples and in geologic and geographic range. Ordovician conodont workers including Webers (1966), Schopf (1966), and Bergström and Sweet (1966) proposed similar multielement apparatuses from large collections of separate elements in acid residues of Middle and Upper Ordovician rocks in the United States. To group elements into apparatuses, they used numerical ratio, common stratigraphic range of elements, similarity of denticulation, basal cavities, white matter distribution, and other details of structure.

Lindström (1968), Jeppsson (1971), and Klapper and Philip (1971) have stressed the importance of models to reconstruct apparatuses from separate elements. These authors argue that only a few arrangements of elements into apparatuses are possible. Jeppsson (1971) discussed two types in the Silurian, and Klapper and Philip discussed four types in the Devonian. Other types of apparatuses are present in the Cambrian and Ordovician, but Lindström (1968) believed that there are only seven or eight basic types. Sweet and Bergström (1972) recognized three major skeletal plans in Ordovician faunas: simple cones, ramiform elements, and ramiform and platform apparatuses.

Klapper and Philip $(1971,1972)$ based their reconstructions of conodont apparatuses on the following logic: (1) thin limestones containing a faunule composed of abundant specimens of a few element species would contain few apparatus species; (2) the model of preserved apparatuses from the Mississippian and Pennsylvanian and the wellaccepted apparatuses of Walliser (1962) from the Silurian, can be used in the Devonian; (3) recurring sets of elements indicate apparatuses; and (4) common morphologic characters suggest elements of an apparatus. Klapper and Philip also concluded that many ramiform elements are vicarious and that the same, or very similar, elements occurred in different apparatuses.

Many authors have pointed out that in most faunas there are far too few ramiform elements to supply the needed numerical ratio between the ramiform and platform elements required by these apparatus models. This fact has generally been explained by the sorting and fragmentation of ramiform elements, rendering them unrecognizable. Many faunal papers have omitted all the ramiform elements because they were regarded as less useful for biostratigraphic studies than the platform ele- ments. Ziegler (1971), on the other hand, argued that enough faunas have been described to indicate that certain elements such as Polygnathus and Palmatolepis may have formed apparatuses composed of a single element. Ziegler's conclusion is supported by the occurrence of conodont elements in the Genundewa Limestone Member.

As previously discussed, the Genundewa Limestone Member was probably deposited in quiet water. The abundant randomly oriented specimens of Styliolina fissurella indicate a lack of currents. The ramiform conodonts, however, are not especially abundant, and a study of table 1 shows that the samples having the largest number of specimens from the Genundewa do not have enough ramiform elements to fill out the model apparatuses for all the platform elements (assuming one pair of each type in the model). In many samples, fragments of ramiform elements cannot be assigned to a form genus. Even including all the fragments, ramiform elements are still far too few to satisfy the apparatus model for all the platform elements present.

To illustrate this conclusion, let us consider the four apparatus species in the Genundewa Limestone Member proposed by Klapper and Philip (1972, p. $99-100 ; 1971$, p. 443-444). These are Polygnathus dubius, $P$. linguiformis, Mesotaxis asymmetrica, and Ancyrodella rotundiloba rotundiloba. Assuming that one pair of each element is needed to satisfy the Klapper-Philip model: For Polygnathus dubius all the elements needed for the KlapperPhilip model apparatus are present but in inadequate numbers. $P$. linguiformis also does not approach the minimum numerical ratio needed for the model. $M$. asymmetrica more nearly fits the model in that the platform element is rare and so are the nothognathellan elements, but I did not find the A-1 and A-2 elements or the palmatodellan element. Moreover, the platform and nothognathellan elements have a different distribution. For $A$. rotundiloba rotundiloba, the numbers of the platform element and O-2 element (Bryantodus retusus) are about adequate, but the surface ornamentation seems to be different, and the range and distribution are different. Perhaps the $B$. retusus element is a "shared" element with a platform of different range. The neoprioniodan and hindeodellan elements needed for the $A$. rotundiloba rotundiloba apparatus model are also in short supply. These collections are not large enough, however, to disprove the suggested apparatus taxa. 


\section{WHY ELEMENT TAXONOMY IS USED IN THIS REPORT}

This report was started before the general recognition of apparatus taxonomy and has been revised to use a modified element taxonomy. In spite of the fact that relative large collections are reported here, they do not lend themselves to "statistical apparatuses." Many of the samples from the Genesee Formation are from beds that have been, or may have been, sorted, for example, the North Evans Limestone of Rickard (1964) and Leicester Marcasite Member of Sutton 1951. On the other hand, the Genundewa Limestone Member is probably unsorted and offers the possibility of establishing apparatus taxa. Klapper and Philip (1971, 1972) used samples from the Genundewa Member at Eighteernmile Creek at N.Y. Highway 5 (Ed-1) to help establish the Polygnathus dubius apparatus (1971) and from Bethany Center (Ba-3) to establish the Ancyrodella rotundiloba apparatus (1972). As shown in table 1, the counts of the elements assigned to these apparatuses do not conform to the minimum number of one pair of each element in the model used by Klapper and Philip.

In the period between the recognition of the necessity for a multielement taxonomy and the establishment of generally accepted apparatus genera and species, both element and apparatus nomenclature will have to be mixed. Probably some of the element taxonomy will prove to be biologically sound; that is, some apparatuses contained only one or two elements. In the meantime, there is enough uncertainty to permit alternate interpretations of the apparatuses assembled from disjunct elements. The fact that some elements seem to have evolved very slowly and are almost or are quite indistinguishable in different apparatus genera adds to the uncertainty of apparatus recognition. Klapper and Philip (1971, 1972) expressed this idea by saying that certain elements are common to other species and genera. This conclusion partly invalidates one of the assumptions that is often made when studying a collection of fossils from a single locality and horizon. In such collections, we assume that probably only one or two species of a genus are present in the collection. This assumption is based on the idea that closely related species are isolated in some way and that it is generally geographic or time isolation. If some elements are indistinguishable in two or more apparatus genera, then a study of the variation of these elements becomes difficult or impossible. The evolution of the bar-type elements and their variation has been little studied, largely because of the biostratigraphic emphasis of most conodont workers. If several species of conodont animal have the same ecologic requirements and very similar elements, it becomes very difficult to sort out the unknown apparatuses, even from large collections. At the present stage of development of conodont taxonomy, new names for bar elements serve no useful purpose and are here assigned to previously described species and synonomized to some extent. Intergrading bar elements might not belong to the same evolutionary lineage, but instead, might be similar because of convergent evolution.

Three or four species probably belong to the apparatus genera: Ozarkodina in the usage of Walliser or Hindeodella of Jeppsson, Delotaxis of Walliser, and Ligonodina of Jeppsson. Too few of these elements were found in the Genesee Formation to permit significant conclusions about the element content and model of these apparatuses: The number of these elements suggests that many ramiform elements belong to species of Ligonodina of Jeppsson and Ozarkodina of Walliser and that many of the platform elements were not associated with ramiform elements. Thus, several fundamental problems are associated with the application of apparatus taxonomy to Late Devonian conodonts, and for the present report, the use of apparatus taxonomy is not warranted.

I have grouped the element taxa under the following headings: platforms and blades; ozarkodinan, neoprioniodontan, hindeodellan, ligonodinan, and lonchodinan elements. This grouping assists in the analysis of the occurrence data in reference to apparatus taxonomy. Symbols for these elements were proposed by Klapper and Philip (1971) and by Jeppsson (1971), but inasmuch as they were not needed for this report, the more general designations are used.

\section{LOCALITY NUMBERS AND TYPE DEPOSITORY}

The collections, including the figured specimens, are at the U.S. National Museum of Natural History. Specimen numbers are indicated by the abbreviation USNM. Locality numbers are those of the U.S. Geological Survey, Silurian and Devonian cata$\log$, indicated by the abbreviation USGS followed by a number and-SD. UMMP numbers refer to specimens from the R. R. Hibbard Collection at the University of Michigan Museum of Paleontology. These specimens are given University of Michigan Museum of Paleontology (UMMP) numbers and are stored there. Robert V. Kesling, Director, Uni- 
versity of Michigan, Museum of Paleontology, kindly loaned the specimens from the Hibbard Collection.

\section{DESCRIPTION OF GENERA AND SPECIES}

PLATFORM AND BLADE ELEMENTS

\section{PLATFORM ELEMENTS}

ANCYRODELLA Ulrich and Bassler 1926

Ancyrodella Ulrich and Bassler, 1926, p. 48; Huddle 1968, p. 6; Ziegler 1962; Khalymbadzha and Chernysheva, 1970; Klapper and Philip, 1972, p. 99; Coen, 1973.

Type species.-Ancyrodella nodosa Ulrich and Bassler 1926, p. 48.

Remarks.-The evolution of the platform element of this genus has been discussed by Ziegler (1962) and Coen (1973), and descriptions and synonomies are given in the references above.

Klapper and Philip (1972) assembled from discrete elements an apparatus genus Ancyrodella. They postulated an apparatus consisting of a platform and bryantodontan, neoprioniodontan, hindeodellan, angulodontan, and hibbardellan elements. These ramiform elements are all present with $A n$ cyrodella nodosa in the original Ulrich and Bassler (1926) collections from the Rhinestreet Shale Member of the West Falls Formation, but I did not count the number of each element in Ulrich and Bassler's original collections, nor did I determine the numerical ratio. In black shale there should be no problem of sorting. My impression is that the numerical ratios do not fit the model.

\section{Ancyrodella rotundiloba (Bryant)}

Polygnathus rotundilobus Bryant, 1921, p. 26-27, pl. 12, figs. 1-6.

Lectotype.-Designated by Ziegler, 1958, p. 44 ; the specimen figured by Bryant 1921, pl. 12, fig. 1, USNM 135043. Refigured here on pl. 1, figs. 1, 2.

Paralectotypes.-USNM 135055, 135063. Bryant's material includes 15 specimens that are probably paratypes, but none of those specimens is recognizable as one of those figured by Bryant, 1921, pl. 12, figs. 2-6, or text fig. 7 .

Diagnosis.-A species of Ancyrodella with rounded anterior lobes and lacking developed secondary keels.

Remarks.-The subspecies is distinguished by considerable variation in the size of the basal pit, the amount of development of the secondary keels, and the suppression of denticles between the blade and the carina. There is a gradation into $A$. rugosa, A. gigas, and A. nodosa.
Ancyrodella rotundiloba rotundiloba (Bryant)

Pl. 1, figs. 1-8, 11-17; pl. 3, figs. 20, 21

Polygnathus tuberculatus Hinde, 1879, p. 366, pl. 17, fig. 10 (not pl. 17, fig. 9, the lectotype of $P$. tuberculatus); Branson and Mehl, 1933, pl. 11, fig. 9.

Polygnathus rotundilobus Bryant, 1921, p. 26-27, pl. 12, figs. $1-6$.

Ancyrodella rotundiloba (Bryant) Hass, 1956, pl. 4, fig. 21; Müller and Clark, 1967, p. 908, pl. 116, figs. 1-5, text fig. 5 , a, b, e; fig. 6 part. (not pl. 115 , fig. 8 , text fig. 5 d, 5 r, and probably not $\mathrm{h}-\mathrm{q},=A$. rotundiloba alata).

Ancyrodella rotundiloba rotundiloba (Bryant) Glenister and Klapper, 1966 , p. 799 , pl. 85, figs. 9-13; Khalymbadzha and Chernysheva, 1970, p. 91-92, pl. 1, figs. 9-12x; Szulczewski, 1971, p. 15, pl. figs. 3, 4; pl. 2, fig. 6 .

Ancyrodella rotundiloba subsp. "A" Uyeno, 1967, p. 5, pl. 1, figs. 1, 3, 6 .

Ancyrodella rotundiloba rotundiloba (Bryant) Multielement species; Klapper and Philip, 1972, p. 99, pl. 2, fig. 1-5. (Ramiform elements questioned here.)

Diagnosis.-The nominate subspecies is characterized by a heart-shaped plate, irregular coarse nodes, a lack of secondary keels, a large basal pit, and a nondenticulated gap between the free blade and carina.

Description.-Plate thick, heart shaped, with round anterior lobes that in some specimens form an anterior notch. Carina-blade, straight or slightly bent and divides the plate into almost equal platform halves. Nodes in the carina distinct or fused into a ridge. Nodes on the oral surface coarse, distinct or fused, and usually arranged irregularly. There are smooth areas in the anterior troughs and parallel to the carina. The free blade has three to six denticles, the highest of which is in the middle. Most individuals have a nondenticulated gap between the free blade and the carina due to the suppression of denticles in the fixed blade. White matter is irregularly developed in the blade and carina, and the youngest layers are clear in wellpreserved material.

The lower side of the conodont has a large diamond-shaped basal pit with furrows extending into the keel and blade. Laterally, the pit extends into incipient keels or keellike folds on some large specimens. Many large specimens, presumably gerontic, have thickened areas on the anterior lobes and outer platform and irregular folds. The crimp is a narrow smooth area, flat or slightly inclined to the plane of the plate. Right- and left-hand forms occur in about equal numbers.

Remarlss.-Müller and Clark (1967, p. 901) showed that in Ancyrodella rotundiloba, the pit size and growth size are not correlated. After the pit forms during the initial deposition of apatite, the pit does not increase in size during subsequent 
growth. Growth takes place in this species above and beyond the basal pit.

Müller and Clark (1967, p. 906-907) interpreted the nondenticulated gap between the blade and carina as due to breakage of denticles. They assumed stress at this point at an early stage of development, causing the denticles to break. The complete carina-blade was interpreted as regeneration of the broken denticles at a later growth stage. Their evidence for this interpretation was the presence of "broken denticles" in clear well-preserved specimens from the Squaw Bay Limestone from the south side of Partridge Point, Alpena County, Mich. The "broken denticles" were said to be covered with clear material in regenerated denticles.

I have examined the specimens illustrated by Müller and Clark (1967) and additional specimens from the Squaw Bay Limestone collected by G. A. Cooper at the same locality and can see no evidence that the denticles were broken and regenerated. Nor have I found evidence in the New York collections for broken and regenerated denticles. White matter is poorly developed in Ancyrodella and, as in other conodonts, seems to consist of minute cavities formed by resorption of material. I think that what Müller and Clark regarded as broken denticles is partial development of white matter, which marks the axis of suppressed denticles in many genera of conodonts. The clear matter above the suppressed denticles is the latest material deposited in which white matter has not formed. When a gap is present, the upper edge is smooth and rounded, and one or two small denticles may be present, but there is no indication of denticle breakage.

I regard the gap in denticles as genetically controlled and think it is one of the characters that distinguish the subspecies of $A$. rotundiloba. I base this conclusion on the fact that the presence of a gap is positively correlated with the absence of secondary keels and the presence of a large basal pit in $A$. rotundiloba rotundiloba, whereas the presence of a continuous blade-carina is positively correlated with secondary keels and a small basal pit in A. rotundiloba alata.

$A$. rotundiloba rotundiloba probably gave rise to $A$. rugosa. It is distinguished from $A$. rugosa by the lack of secondary carina and keels, by rounded outline, and by the irregular arrangement of nodes.

The species $A$. rotundiloba rotundiloba was evolving during the Genesee. The early specimens in the Penn Yan Shale Member and North Evans Limestone of Rickard (1964) are rounded, have irregular nodes, and lack secondary carinae. In the Genun- dewa Limestone and West River Shale Members, the median member of the species has pointed lobes and regular nodes, and it may have secondary carinae. I was not able to separate this evolutionary series into subspecies.

Occurrence.-In New York, this subspecies occurs in the Leicester Marcasite Member of Sutton (1951), the North Evans Limestone of Rickard (1964), and the Penn Yan Shale, Genundewa Limestone, Ithaca, and West River Shale Members of the Genesee Formation and Crosby Sandstone Member as used by Torrey and others (1932) in western New York.

Other localities.-Lower New Albany Shale of Indiana; Upper Devonian, Marys Mountain, Nev.; Waterways Formation, Alberta, Canada; Gogo and Virgin Hills Formations, Canning Basin, Australia; Adorf-Stufe, Roteisenstein, Tagebau, Martenburg, Germany; Riffazies, Aachen, Germany; Cardaño Formation, Cardaño-Triollo area, Spain; Holy Cross Mountains, Poland.

Geologic range.-In North America, in the $A n$ cyrodella rotundiloba and $A$. gigas Zones. In Europe, Ziegler (1971) reported the range as Lower, Middle, and early Upper Polygnathus asymmetricus Zone. In Belgium (Bouchaert and Streel, 1974), it appears in Zone 19 at the base of the Assise de Franses.

Ancyrodella rotundiloba alata Glenister and Klapper

Pl. 1, figs. 9, 10, 23-27, pl. 2, figs. 1-28

Ancyrodella rotundiloba (Bryant) Hass, 1956, pl. 4, fig. 21. Bischoff and Ziegler, 1957, p. 42, pl. 16, figs. 5-12, 1417; Ziegler, 1958, p. 44-45, pl. 11, fig. 12 (not pl. 11, fig. $11=A$. rotundiloba rotundiloba); Müller and Clark, 1967, p. 908-909, pl. 115, figs. 8 a-c, text fig. 2, a?, b, e, $\mathrm{f}$, text fig. 5, d, text fig. $6 \mathrm{f}-\mathrm{r}$ (not pl. 116, figs. $1 \mathrm{a}-\mathrm{c}$, 2 a-c, 3, 4, 5 a-c, text fig. 2, c, d, text fig. 5 a-c, e, text fig. $6 \mathrm{a}-\mathrm{d}, \mathrm{w}(=A$. rotundiloba rotundiloba) ; text fig. 6 $\mathrm{s}-\mathrm{v}$ not determined).

Ancyrodella rotundiloba alata Glenister and Klapper, 1966, p. $799-800$, pl. 85 , figs. $1-4$; Pollock, 1968, p. 424, pl. 61, figs. 2-3.

Holotype.-The specimen figured by Glenister and Klapper, 1966 , p. 800 , pl. 85 , figs. $7,8$.

Diagnosis.-This subspecies has an asymmetrical plate outline with the outer platform lobed anteriorly, a continuously denticulated carina-blade and partially developed secondary keels. The keel on the inner platform extends anteriorly from the basal pit and may reach the crimp, but not the platform margin. The keel on the outer platform extends laterally from the basal pit, but usually does not reach the crimp. The nodes on the oral surface are smaller and more regularly arranged than in $A$. rotundiloba rotundiloba. 
Description.-Plate thick, outer platform lobate and slightly larger than the inner platform. Blade and carina usually continuously denticulate so there is no gap between the blade and carina. Denticles increase in size posteriorly. Oral surface has small nodes, mostly discrete but some fused. Nodes may be arranged randomly, but in most specimens they are arranged in rows parallel or perpendicular to the carina and may suggest secondary carinae.

The basal pit is smaller than that of the nominate subspecies. Grooves extend along the keel in front of and behind the pit. Secondary keels extend from the pit laterally on the outer platform and anteriorly on the inner platform, reaching the crimp on some individuals (pl. 2, fig. 16).

Remarles.-All the distinguishing characters of the two subspecies of $A$. rotundiloba are variable, and some specimens are difficult to assign. A. rotundiloba alata is distinguished from $A$. lobata by the incomplete secondary keels. In $A$. lobata, the secondary keel on the inner platform reaches the crimp, and there is a matching anteriorly directed keel on the outer platform. A laterally extending keel may also be present on the outer platform. $A$. lobata also has well-developed secondary carinae above the secondary keels and may have an additional carina on the outer platform above the laterally directed keel.

The elements assigned to the multielement species A. rotundiloba alata by Klapper and Philip (1972) differ from one another in their denticle structure. The platform and the bryantodontan elements have very little white matter and clear laminated material in the tips of the denticles. The ramiform elements they assigned have considerable white matter and denticles that appear to be inserted.

Occurrence.-In New York at localities Ed-1 and SC-1, this subspecies occurs in the Leicester Marcasite Member of Sutton (1951), the North Evans Limestone of Rickard (1964), the Penn Yan Shale, Genundewa Limestone, and West River Shale Members of the Genesee Formation. At localities to the east, it ranges from the Penn Yan Shale Member to the upper part of the West River Shale Member of the Genesee Formation. It has not been found in the Geneseo Shale Member.

Outside New York, the species is reported from the Chattanooga Shale in Tennessee, Squaw Bay Limestone in Michigan, Maligne Formation in Alberta, Gogo Formation in Australia, Lower and Middle asymmetricus-Zone in Germany. Coen (1973) reported it from the Assise de Franses in Belgium.
Geologic range.-In the United States, from $A n$ cyrodella rotundiloba to $A$. gigas Zone. In Germany, from Lower Polygnathus asymmetricus-Zone to Upper $P$. asymmetricus-Zone.

\section{Ancyrodella rugosa Branson and Mehl \\ Pl. 1, figs. 18-22; pl. 3, figs. 1-19}

Ancyrodella rugosa Branson and Mehl, 1934a, p. 239, pl. 19, figs. 15, 16; Beckmann, 1949, p. 155, pl. 1, fig. 1 a, b, pl. 4, fig. 2; Bischoff and Ziegler, 1957, p. 42, pl. 16, fig. 13; Krebs, 1959, pl. 1, fig. 14; Pollock, 1968, p. 428, pl. 61, fig. 1.

Ancyrodella cf. rugosa Branson and Mehl. Spasov, 1964, p. 271-272, pl. 2, fig. 6 .

Holotype.-Univ. of Missouri, C224-1, Grassy Creek Shale, Dixie, Mo. Conodonts from this locality are from the Holts Summit Formation or Massie Creek Sandstone of Mehl (1960), Mehl and Ziegler (1962).

Diagnosis.-An arrowhead-shaped species of $A n$ cyrodella with partially developed secondary carina and keels, and with regularly arranged nodes next to the carina.

Description.-Plate thick with bluntly pointed anterior lobes, discrete or fused nodes which are more or less alined to form secondary carina and rows of nodes parallel to the carina or plate margin. Blade-carina continuous and denticulated throughout. Basal pit small, keel sharp, and secondary keels generally indistinct. A thickened ridgelike keel extends slightly forward from the pit but does not reach the crimp on the outer platform.

Remarks.-A. rugosa is distinguished from $A$. rotundiloba rotundiloba by the presence of more regularly arranged nodes and partially developed secondary carina and keels. It differs from $A$. rotundiloba alata in the lack of a lateral lobe on the outer platform, the lack of a laterally directed secondary keel, and the presence of an anteriorly directed keel on the outer platform. A. nodosa, $A$. lobata, $A$. buckeyensis, and $A$. gigas differ in the complete development of secondary keels.

$A$. rugosa probably developed from $A$. rotundiloba and apparently evolved into $A$. gigas by lengthening, arranging the nodes more regularly, and fully developing the secondary keels and carina.

Occurrence.-In New York, A. rugosa occurs in the Ithaca and West River Shale Members of the Genesee Formation at localities $\mathrm{I}-3, \mathrm{Wg}-13, \mathrm{Wg}-1$, $\mathrm{Py}-7, \mathrm{Cd}-5, \mathrm{Cl}-4, \mathrm{Hy}-2$, and $\mathrm{Dp}-1$ and in the Genundewa Limestone Member at Clover Bank (Ed-2). Elsewhere, it is found in the Holts Summit Formation or Massie Creek Sandstone of Mehl (1960) of Dixie, Mo.; Maligne, Majeau Lake, and 
Beaver Hill Lake Formations, Alberta, Canada; Iberger Kalk, Obere Stringocephalen-Stufe, Polygnathus asymmetricus-Zone Germany; Kraiste, Bulgaria.

Geologic range.-Lower to Upper Polygnathus asymmetricus Zone in the European standard zonation. In the Ancyrodella rotundiloba rotundiloba and $A$. gigas Zones in North America.

\section{ICRIODONTIDAE \\ (Icriodidae Müller and Míller, 1957) ICRIODUS Branson and Mehl}

Icriodus Branson and Mehl, 1934a, p. 225; 1938, p. 159-160. Müller and Müller, 1957, p. 1105; Philip, 1965, p. 103; Anderson, 1966, p. 404-405; Klapper, 1966, p. 29-30; Clark and Ethington, 1966, p. 679; Bultynck, 1970, p. 100-102.

Type species.-Icriodus expansus Branson and Mehl, 1938.

Diagnosis.-Icriodus is distinguished from most conodont genera by its wide-open basal cavity which extends the full length of the plate and expands beyond the margins of the plate in some species. Normally, the oral surface of the plate has three rows of nodes (denticles), but some species have a reduced middle row.

Remarks.-The principal diagnostic characters of species, according to Bultynck (1970, p. 101), are: (1) Outline and contour of the basal cavity, (2) posterior-lateral projections (perhaps a generic character), (3) outline of the oral surface, (4) shape and fusion of nodes and relative position of median and lateral rows, (5) shape of blade and inclination of cusp in lateral view. The outline of the oral surface, the shape of the nodes, and the amount of fusion change during ontogeny. Young specimens tend to have round discrete nodes that become fused in later growth, and the oral outline becomes broader during growth. The rims of the basal cavity are broken in most specimens, and these specimens are difficult to assign to species.

Icriodus differs from Pelekysgnathus in having three rows of nodes on the oral surface, whereas most Pelekysgnathus have only a single row, but some intergrading forms have extra rows.

Geologic range.-The genus is restricted to the Devonian and it has a worldwide distribution. Icriodus latialatus Walliser from the Silurian Ludlovian is now referred to the genus Pedavis by Klapper and Philip (1971).

\section{Icriodus eslaensis Adrichem Boogaert \\ Pl. 4, figs. 1-29}

Icriodus eslaensis Adrichem Boogaert, 1967, p. 180-181, pl. 1, figs. 9-12.
Icriodus eslaensis assemblage Adrichem Boogaert. Bultynck, 1972, p. 81, fig. 14.

Icriodus cymbiformis? Branson and Mehl. Stauffer, 1938, p. 430, pl. 52, figs. 11, 13.

Icriodus cymbiformis Branson and Mehl. Stauffer, 1940, p. 425 , pl. 601 figs. 37, 51, 56-58, 68; Wirth, 1967, p. 215, pl. 20, figs. $18 \mathrm{a}, \mathrm{b} ; 19 \mathrm{a}, \mathrm{b}$.

?Icriodus cymbiformis Branson and Mehl. Lys and Serre [in, Lys, Serre and Deroo, 1957], 800-801, pl. 9, fig. 3; Panseri and Barsotti, 1959, p. 157-158, pl. 1, fig. 5.

Icriodus expansus Branson and Mehl. Stauffer, 1940, p. 425, pl. 60 , figs. $59,64,70,71$; not figs. $40,47,48,60-63=I$. expansus.

Diagnosis.-A small slender species of Icriodus with the median row of denticles extending three or four denticles behind the lateral rows. Last denticle broader and slightly longer than the other denticles. Median row of denticles does not reach the anterior tip of the unit.

Remarks.-The small species Icriodus cymbiformis Branson and Mehl and I. brevis Stauffer are similar to I. eslaensis. I. cymbiformis has been regarded as juveniles of other species by authors, and $I$. brevis is placed as a juvenile $I$. cymbiformis by Anderson (1966). I. cymbiformis probably lacks the large end denticle of $I$. eslaensis.

Geologic range.-In New York, this species ranges from the "Lower Member" of the Tully Limestone to the Geneseo Shale Member of the Genesee Formation. The type of the species comes from the basal La Portilla Formation in the Rio Esla area, Spain, in the Polygnathus varcus Zone.

$$
\begin{gathered}
\text { Icriodus latericrescens latericrescens Branson and Mehl } \\
\text { Pl. 5, figs. 1-6 }
\end{gathered}
$$

Icriodus latericrescens Branson and Mehl, 1938, p. 164-165, pl. 26, figs. 30-37.

Icriodus latericrescens latericrescens Branson and Mehl. Klapper and Ziegler, 1967, p. 74-75, pl. 10, figs. 4-9, pl. 11 , figs. 1-5; Seddon, 1970 , p. $53-54$, pl. 4, figs. 4-7. (See Klapper and Ziegler, 1967, for synonymy.)

Lectotype.-Specimen figured by Branson and Mehl, 1938, pl. 26, fig. 34, and Klapper and Ziegler, 1967, pl. 11, fig. 4a, b. Univ. Missouri Cat. No. C-249-1 Mineola Limestone of Branson (1920) (probably a member of the Cedar City Formation of Fraunfelter, 1965) about 2 miles north of Big Springs, Montgomery County, Mo.

Diagnosis.-Outer lateral process joins main platform anterior to the posterior tip. Median carina is an incomplete fused ridge or elongate compressed nodes in a trough. Lateral rows have discrete round nodes.

Remarks.-The Icriodus latericrescens group has been split into several species and subspecies. These species and subspecies are difficult to distinguish, 
and all may not be distinct. The nominative form seems to be the end member of the group. It is distinguished most easily by the reduction of the median row of nodes and the depression of the central trough in the main platform. The aboral view is also distinctive.

Geologic range.-I. latericrescens s.s. is confined to the $P$. varcus Zone in Germany. In New York, it ranges from the base of the Skaneateles Shale of the Hamilton Group to the Genundewa Limestone Member of the Genesee Formation (Klapper and others, 1971, fig. 2).

Icriodus nodosus (Huddle)

Gondolella? nodosa Huddle, 1934, p. 94, pl. 8, figs. 24, 25.

Icriodus nodosus (Huddle). Branson and Mehl, 1938, p. 163, pl. 26, figs. 14-17, 22; Bultynck, 1970, p. 106-107, pl. 3, figs. $1-10$, pl. 4 , figs. $1-6$, pl. 30 , figs. $7-8$ (see for additional synonomy).

Holotype.-Indiana Univ. Paleontology Colln. 1940. Lost. Four specimens (paratypes) from the type series USNM 208015, 208016 from loc. 33 of Huddle $(1934$, p. 31$)$ near Hayden, Ind. Probably from unit 8, Selmier Member of New Albany Shale of Lineback, 1970, p. 58-59.

Remarks.-Branson and Mehl, 1938, distinguished I. nodosus from $I$. expansus on the basis of the abrupt offset in the semicircular aboral outline of the expanded part of the basal cavity, and the subparallel sides of the oral outline. Since 1938, many authors have recognized $I$. nodosus on the basis of the hook or horn in the aboral outline. Bultynck (1970) recognized four subspecies of $I$. nodosus but did not describe $I$. nodosus nodosus. In addition to the subspecies of $I$. nodosus, several other species of Icriodus have similar hooks in the aboral outline; illustration and description of additional specimens of $I$. nodosus s.s. are needed.

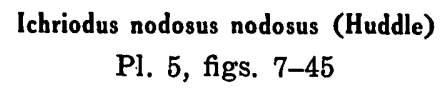

Gondolella? nodosa Huddle, 1934, p. 94, pl. 8, figs. 24, 25.

Icriodus nodosus (Huddle). Branson and Mehl, 1938, p. 160, pl. 26, figs. 14-17, 22; Mehl and Quigley, in Branson, 1944, pl. 26, fig. 6; Stewart and Sweet, 1956, p. 259, pl. 33 , figs. 8, 10; Wirth, 1967 , pl. 20, figs. 24a, b; Schumacher, in Clark, 1971, p. 93-95, pl. 9, figs. 19-29. See Schumacher (in Clark, 1971) for additional synonomy. He placed $I$. expansus Branson and Mehl as a junior synonym of $I$. nodosus (not pl. 9, figs. $1-18=I$. nodosus curvirostratus? Bultynck; lacks median node at anterior pair of lateral nodes.)

Material.-Four unfigured paratypes from loc. 33, Huddle, 1934. More than 400 specimens from the basal sandstone of the New Albany Shale at the Speed quarry of the Louisville Cement Co., Clark
County, Ind. (collected by C. A. Pollock and C. B. Rexroad). Five specimens from the basal sandstone of the New Albany at the Meshberger quarry near Columbus, Ind. (collected by C. A. Pollock). More than 1,000 specimens from the Tully Limestone and the Genesee Formation.

Diagnosis.-This subspecies is characterized by the slight curvature of the axis, the fused high nodes in the carina, and the roughly trapezoidal aboral outline of the basal cavity. The posterior edge of the cavity is nearly straight, and the prominent lateral hook and resultant trough are diagnostic.

Description.-Orally, the entire unit is straightsided in young specimens and biconvex in mature specimens. The median row of nodes extends to the anterior paix of lateral nodes in most mature specimens. The nodes are round and discrete in young specimens and tend to become flattened and fused in mature and gerontic individuals. Young specimens have straight median carina, but older specimens have a curved anterior tip, and mature specimens have a curved axis. The posterior extension of the median carina has two or three denticles and the largest denticle or cusp, at the rear is variable in size and inclination of the posterior margin, as seen in lateral view.

Remarks.-The holotype of Gondolella? nodosa, Indiana Univ. Paleont. Colln. 1940, is not in the collections at Indiana Univ. and is presumed lost. Branson and Mehl borrowed the type and refigured it in their 1938 paper on the genus Icriodus. R. L. Ethington searched the collections at Missouri but failed to find the type of G.? nodosa. I removed the holotype from hard black shale collected at Chelsa, Ind., from the basal 2 feet of the New Albany Shale (Huddle (1934) loc. 27). The rim of the basal cavity was probably broken, but Branson and Mehl apparently established that the holotype and an additional specimen had a hook or spur on the basal cavity, because they considered the spur to be diagnostic of the species. This concept has been followed by later authors.

My original description of Gondolella? nodosa (Huddle, 1934) was based on the holotype and one other specimen from the base of the New Albany Shale at my loc. 27, Chelsa, Ind. (both lost), and four specimens from my loc. 33 about 15 feet above the base (Selmier Member of Lineback, 1968). The illustrated specimens in my 1934 paper were placed in the Indiana University Collections, and the other specimens were placed later in the U.S. National Museum. These specimens are paratypes according 
to the glossary of the International Code of Zoological Nomenclature.

The specimens from loc. 27 are from the "Schmidtognathus hermanni-Polygnathus cristatus" Zone. Thus, the paratypes of G.? nodosa are not from the same stratigraphic horizon. Gilbert Klapper and P. Bultynck attempted to find additional specimens of G.? nodosa at Chelsa in 1972 but failed (Klapper, written commun., 1974). Abundant specimens are available from the thin limestone at the base of the New Albany Shale at the Louisville Cement Co. quarry, lot 132, Clark's Grant, Clark County, Ind., and at Meshberger Stone Co. quarry, Bartholomew County, Ind. These are thought to come from the same horizon as the Chelsa locality (27) and do represent the same conodont zone. I am indebted to C. A. Pollock and Carl B. Rexroad for these collections. I have studied about 400 specimens from these localities.

Examination of the specimens from the basal New Albany Shale convinces me that Branson and Mehl were correct in their identification of $I$. nodosus from the Genundewa Limestone Member with G.? nodosa from the New Albany Shale. I also have no doubt that the paratypes from the Selmier Member of the New Albany Shale of Lineback (1968) are also the same species, even though they come from different stratigraphic horizons. The species is characterized by the spur, the slight curvature of the median row of nodes, and the tendency of the nodes in the median row to be fused into a semiridge higher than the outside rows. The thin-walled basal cavity of the species is easily broken, especially the spur, but the spur's former presence is indicated by a trough in the cavity wall leading inward in most specimens.

Specimens from the basal New Albany Shale vary in the characters used to distinguish species in the genus Icriodus. Fusion and flattening of the nodes increase with element size as does the curvature of the axis. The outline of the expanded part of the basal cavity also varies, some individuals being more round and others more nearly square than the typical trapezoidal outline. Specimens with a curved axis and a thin sharp ridge connecting the nodes in the median carina approach $I$. symmetricus Branson and Mehl. A similar degree of variability is shown by the specimens from the Tully Limestone and the Genesee Formation in New York.

After reviewing an early draft of this description, Gilbert Klapper (written commun., 1975) sent me a copy of his description of Icriodus symmetricus Branson and Mehl and photographs of the holotype.
The description and photographs have been published subsequently (Klapper, in Ziegler, 1975). As noted by Klapper, the type locality is Sees Creek, Mo., (Branson and Mehl, 1934, p. 226), but the type slide (C 243-1) is labeled Dixie, Mo. The type locality, therefore, is somewhat in doubt, and topotype material to determine the range of variation is ambiguous. However, the photographs of the lectotype suggest to me that $I$. symmetricus is the senior synonym of $I$. nodosus. The description prepared by Klapper does not mention the presence of a spur, and until the presence of a spur in I. symmetricus is established, I will continue to use $I$. nodosus.

Stewart and Sweet (1956, p. 269) and Müller and Clark $(1967$, p. 914$)$ have suggested that $I$. nodosus and $I$. expansus Branson and Mehl intergrade, but they did not synonomize the species. Schumacher (in Clark, 1971) made $I$. nodosus the senior synonym of I. expansus. Bultynck (1972) recognized a transition series between certain Middle Devonian form species of Icriodus and proposed that these be placed in multielement apparatus species. $I$. nodosus, $I$. alternatus B. and M., and I. symmetricus, as well as I. expansus may all belong to the same multielement apparatus. They occur at about the same stratigraphic position and seem to intergrade. If future studies prove this speculation to be correct, I. symmetricus is the oldest name having well-illustrated types. Bultynck $(1970$, p. 113$)$ distinguished 1 . symmetricus from other species on the basis of a narrow oral outline, rounded expansion of the basal cavity one-third or less than the length of the unit, and a median carina higher than the outer rim of nodes. I think that Branson and Mehl's figures (1934a, pl. 13, fig. 1) of the syntypes show a hook on the basal cavity and that their plate 13 , figure 3 , which shows the rounded basal cavity is of a broken specimen.

Bultynck (1970) named other subspecies of $I$. nodosus on the basis of minor differences in the rate of expansion, general shape of the basal cavity, and the shape of the lateral spur. These subspecies have stratigraphic significance according to Bultynck. I. nodosus nodosus is quite similar to I. symmetricus introlevatus Bultynck, but the latter lacks a true spur. However, Bultynck's (1970) figures 1 and 2 on plate 5 seem to show a distinct spur.

Geologic range.-I. nodosus nodosus occurs in the Tully Limestone and the Genesee Formation as high as the Genundewa Limestone Member in New York. It also occurs in the Squaw Bay Limestone, in Michigan, and the Lake Church Formation of Pohl (1929) and Milwaukee Formation in Wisconsin. 
PALMATOLEPIS Ulrich and Bassler 1926

Palmatolepis? disparalvea Orr and Klapper

Pl. 6, figs. 1-7

Palmatolepis? disparalvea Orr and Klapper, 1968, p. 10711072, pl. 140, figs. 1-11; Pölsler, 1969, p. 410-411, pl. 4, figs. 11-21; Schönlaub, 1969, p. 312-313, pl. 2, figs. 3, 13.

Remarks.-The types of this species come from the crinoidal limestone at the base of the New Albany Shale in the Meshberger Stone Co. quarry, Bartholomew County, Ind. This limestone is a lag deposit, or at least is current sorted, so it will be difficult to determine the associated elements at the type locality. This is true of the New York localities also, and most of the New York specimens are broken. Possibly no other elements were present in this apparatus.

Occurrence.-In New York, this species occurs at the following localities: Cl-4, Ba-3, At-1, Dp-1, Ed-2, Ed-1 in the Leicester Marcasite Member of the Moscow Formation of Sutton (1951), the North Evans Limestone of Rickard (1964), and the Penn Yan Shale, and Genundewa Limestone Members of the Genesee Formation.

\section{POLYGNATHUS Hinde 1879}

Polygnathus alatus Huddle

Pl. 6, figs. 24-28; pl. 7, figs. 1-8

Polygnathus alatus Huddle, 1934, p. 100, pl. 8, figs. 19-20.

Diagnosis.-Characterized by the smooth upper surface, deep troughs, and high lateral margins. Posterior tip tends to be rounded in large specimens. Basal pit reduced to a slit in most specimens.

Remarles.-Differs from $P$. glaber Ulrich and Bassler, $P$. decorosus, and $P$. xylus in the high plate margins, asymmetrical plate, and rounded posterior tip.

This is not an abnormal or gerontic $P$. dubius because young specimens show the smooth upper surfaces.

Occurrence.-In New York, it is found at the following localities: Dy-10, I-3, Ov-12, Py-15, Cd-12, $\mathrm{Nap}-4, \mathrm{Cd}-7, \mathrm{Cl}-2, \mathrm{Cl}-4, \mathrm{Cl}-5, \mathrm{Ba}-3, \mathrm{Ba}-2$, At-1, $\mathrm{Dp}-3, \mathrm{Dp}-1, \mathrm{Ed}-1, \mathrm{Ed}-2, \mathrm{SC}-1$ in the Tully Limestone, the Leicester Marcasite Member of Sutton (1951), the North Evans Limestone of Rickard (1964), and the Geneseo Shale, Penn Yan Shale, and Genundewa Limestone Members of the Genesee Formation; the Marathon Sandstone and Williams Brook Coquinite Members of the Ithaca facies of Caster (1933); and the Crosby Sandstone Member as used by Torrey and others (1932) and the Ithaca Member of the Genesee Formation.

\author{
Polygnathus alveoliposticus Orr and Klapper \\ Pl. 6, figs. 8-14; pl. 7, figs. 9, 10
}

Polygnathus alveoliposticus Orr and Klapper, 1968, p. 10731074, pl. 139, figs. 10-18.

Remarls. - This species was reported as Polygnathus cristatus Hinde by Davis (1966) and Mayr (1968). It is similar to species of Polylophodonta, but it lacks the characteristic adcarinal trough of that genus.

Occurrence.-Tully Limestone at localities : Gen-5, $\mathrm{Ph}-6, \mathrm{Cd}-12$; and Leicester Marcasite Member of the Moscow Formation of Sutton (1951) at Dp-1 (reworked?). Reported from the Antrim Shale and the New Albany Shale by Orr and Klapper (1968).

\section{Polygnathus aff. P. angustidiscus Youngquist Pl. 17, figs. 1-9}

Polygnathus angustidiscus Youngquist, 1945, p. 365, pl. 54, fig. 2.

Ctenopolygnathus angustidisca (Youngquist). Müller and Müller, 1957, p. 1084-1085, pl. 136, figs. 1a, b.

Polygnathus angustidisca Youngquist. Ziegler, 1962, p. 8586; Anderson, 1966, p. 410.

?Polygnathus angustidisca Youngquist. Mound, 1968, p. 503, pl. 68 , figs. $19,20$.

Diagnosis.-A long, narrow polygnathid, with an imcomplete plate, high rims, and deep adcarinal troughs. Aborally, the crimp is high and steep, keel sharp, and pit teardrop shaped and thin walled. Nodes on the high rims of the plate inconspicuous.

Remarks.-Anderson (1966) placed Polygnathus unicornis Müller and Müller in synonomy with $P$. angustidicsus. This assignment seems doubtful to me. The specimen figured by Mound (1968) seems to be a young specimen and may not belong in this species, because it has strong nodes like $P$. angustipennatus Bischoff and Ziegler. The recognition of this species is hampered by fact that Müller and Müller (1957) and Anderson (1966) did not figure typical specimens of the species, and Youngquist's (1945) original illustration is a poor drawing of a broken specimen.

Occurrence.-West River Shale Member of the Genesee Formation, Chidsey Point Gully (Py-7).

Polygnathus asymmetricus asymmetricus Bischoff and Ziegler

Pl. 7, figs. $11,12,19-22$; pl. 8, figs. 1-3, 5-7, 15, 16

Polygnathus dubia Hinde. Beckmann, 1949, p. 154, pl. 1, fig. 3 , pl. 2, figs. 10,11 , pl. 4, fig. 4 .

Polygnathus dubia asymmetrica Bischoff and Ziegler, 1957, p. $88-89$, pl. 16 , figs. $18,20-22$, pl. 21, fig. 3; Ziegler, 1958 , p. $57-58$, pl. 1 , figs. $4-6,8-10$; Krebs, 1959 , pl. 1 , fig. 3; Clark and Ethington, 1967, p. 61, pl. 7, fig. 18; Bartenstein and Bischoff, 1962, p. 52, pl. 5, figs. 4-5.

Polygnathus dubia dubia Hinde. Clark and Ethington, 1967, p. $60-61$, pl. 7 , figs. 14,15 . 
Polygnathus asymmetricus asymmetricus Bischoff and Ziegler. Ziegler and Klapper 1964, in Ziegler, Klapper, and Lindström, 1964, p. 423; Ziegler, 1965b, [1966], pl. 5, figs. 9-10; Glenister and Klapper, 1966, p. 828, pl. 88, figs. 6-7; Mound, 1968 , p. 502, pl. 68, figs. 8-9; Kirchgasser, 1970, p. 345-346, pl. 63, fig. 9.

Polygnathus cristata Hinde. Bischoff and Ziegler, 1957, pl. 15, figs. 8-9, 11-13, 16; Clark and Ethington, 1967, p. 59-60, pl. 7, figs. 16-17.

Remarks.-P. asymmetricus asymmetricus is distinguished by its asymmetrical outline with the inner plate margin flattened and outer margin rounded, and by its thin plate, small pit, and fine growth lines. The plate is arched, and in young specimens the margins are level with the base of the carina, rather than raised as in $P$. dengleri. Mature specimens of this subspecies tend to have upturned margins and much higher rims. The size of the nodes on the upper surface ranges from fine to coarse, but not as coarse or sharp as in $P$. cristatus.

Gerontic specimens have some fused nodes, high margins, and a thick plate. Transitional forms to Palmatolepis transitans have a small basal cavity, a lateral lobe, and central node. $P$. asymmetricus asymmetricus differs from $P$. asymmetricus ovalis in the nearly straight inside margin.

Occurrence.-In New York, this species occurs in the North Evans Limestone of Rickard (1964) and the Genundewa Limestone, and West River Shale Members of the Genesee Formation at localities $\mathrm{Wg}-1, \mathrm{Py}-7, \mathrm{Cd}-5, \mathrm{Dp}-3, \mathrm{Dp}-1$, and Ed-1.

Polygnathus asymmetricus ovalis Ziegler and Klapper

Pl. 7, figs. 23-26; pl. 8, figs. 10, 13; pl. 14, figs. 1-5; pl. 16, figs. 23-25

Polygnathus dubia dubia Hinde. Bischoff and Ziegler, 1957, p. 88 , pl. 18-19, pl. 21, figs. 1, 2; Ziegler, 1958, pl. 1, figs. 1, 2a, b, 3, 7a, b; Bartenstein and Bischoff, 1962, p. 52, pl. 5, fig. 3; Müller and Clark, 1967, p. 916, pl. 115 , figs. $5 a-c, 6$.

Polygnathus asymmetricus ovalis Ziegler and Klapper, 1964 (in Ziegler, Klapper, and Lindström, 1964), p. 422, 423; Ziegler, 1965b, p. 676, pl. 5, fig. 6; Ziegler, 1965a, p. 538, pl. 1, figs. 3 , 4; Ethington, 1965 , p. 581 , pl. 68 , fig. 1?; Glenister and Klapper, 1966 , p. 828 , pl. 87 , figs. 8, 9; Mound, 1968, p. 504, pl. 69, figs. 4-5?; Pölsler, 1969, p. 420 , pl. 4, figs. 17,18 .

Holotype.-Specimen figured by Ziegler 1958, pl. 1, figs. 1, 2a, b.

Remarks.-P. asymmetricus ovalis differs from $P$. asymmetricus asymmetricus in the shape of the plate. The plate is oval with both margins round, rather than flattened on the inside. Many specimens are difficult to assign because there is a complete range in the shape of th platform from symmetrically oval to strongly asymmetrical.
P. a. ovalis has a smaller, more round pit, flatter plate margins, and the posterior tip of the plate is more round than $P$. dengleri. $P$. dengleri has raised plate margins and an elongate, teardrop-shaped pit.

$P$. a. ovalis has finer unfused nodes, a shorter blade, and a more central basal cavity than does $P$. ectypus ( $P$. cristatus sensu Bischoff and Ziegler). Also, the anterior end of the plate of $P . a$. ovalis is more pointed.

Occurrence.-Only a few specimens are assigned to this subspecies from the following units in the Genesee Formation: North Evans Limestone of Rickard (1964) (Ed-1, Ed-2); Geneseo Shale (Gen-2), Penn Yan Shale (Dp-3), and Genundewa Limestone ( $\mathrm{Ba}-3)$ Members; and questionably from the Crosby Sandstone Member of the Standish Formation as used by Torrey and others (1932) in the Ithaca Member (Py-15).

Polygnathus asymmetricus unilabius n. subsp.

Pl. 7, figs. 13-15; pl. 8, figs. 4, 8, 9, 11, 12, 14

Polygnathus asymmetricus ovalis Ziegler and Klapper. Mound, 1968, pl. 69, figs. 4, 5.

$P$. asymmetricus asymmetricus Seddon, 1970, pl. 10, fig. 2a-b.

Holotype.-188808 USNM, USGS 6754-SD. Py-7 illustrated on pl. 8, figs. 8-9. Paratypes all from West River Shale Member, Genesee Formation, at locality 6754-SD, 19-19.5 feet below the top of the formation.

Material.-More than 200 specimens from 5 localities.

Origin of name.-Greek uni, meaning one, and labius, meaning lip.

Diagnosis.-This subspecies is distinguished by the asymmetrical basal cavity extending laterally as a broad lobe or lip on the larger side of the platform.

Description.-A subspecies of Polygnathus asymmetricus with a large asymmetrical pit. Plate ovate, slightly asymmetrical, slightly arched, and moderately thin. Axis nearly straight with a high blade nearly confined to the plate. Ornamentation variable with strong nodes, smooth areas, and fused nodes on different specimens.

Keel sharp edged with a slitlike basal cavity near the middle of the plate at the point of arching and a large asymmetrical lip on the larger half of the plate. Growth lines relatively fine.

Remarks.-This subspecies seems to be intermediate between $P$. dengleri and $P$. a. asymmetricus. It is similar to $P$. dengleri in the thick-lipped basal cavity and the lack of ornamentation in the troughs next to the carina on many specimens. In shape, some specimens approach the outline of $P . a$. asym- 
metricus, but most are more pointed like $P$. dengleri. Some specimens are ornamented like $P$. a. asymmetricus, and the nodes are present in the troughs next to the carina. The denticles in the carina are more completely fused in $P$. asymmetricus unilabius than in the related species. The denticles near the position of the principal node in Palmatolepis (above the basal cavity) are larger and higher than those nearer the ends of the carina.

Occurrence.-This subspecies is found in the West River Shale Member of the Genesee Formation in New York at localities: $\mathrm{Py}-7, \mathrm{CD}-5, \mathrm{Hy}-2, \mathrm{Dp}-1$. It also occurs in the section at Martenberg near Adorf, West Germany, in the Roteisenstein, $0.1 \mathrm{~m}$ below the Obere Pharciceras layer in the Lower asymmetricusZone, and in the lower and middle Duvernay and lower Beaverhill Lake of southern Alberta in the Upper Polygnathus asymmetricus Zone and the $A n$ cyrognathus triangularis Zone (Mound, 1968).

Polygnathus aff. P. brevilaminus Branson and Mehl

$$
\text { Pl. 17, figs. 35-37 }
$$

Polygnathus brevilamina Branson and Mehl, 1934a, p. 246, pl. 21, figs. 3-6.

Remarlss.-The specimen figured here from the Genundewa Limestone Member of the Genesee Formation is similar to the specimens figured by Branson and Mehl. Their specimens seem to be young individuals, and the specimen figured here may be a young specimen of $P$. collieri, $P$. cristatus, or a freak specimen of some other coarse-ribbed species of Polygnathus.

It differs from $P$. aff. $P$. angustidiscus in having coarse ribs.

Occurrence.-North Evans Limestone of Rickard (1964), Amsdell Creek; R. R. Hibbard Colln., Univ. Michigan Paleo. Museum.

Polygnathus? caelatus Bryant

Pl. 11, figs. 15-18; pl. 12, figs. 7-18, 22-24; pl. 13, figs. $1-6,12,13$

Polygnathus caelatus Bryant, 1921, p. 27, pl. 13, figs. 1-6, 8, 12, 13 (not figs. $7,9,10,11=$ Polygnathus collieri n. sp., the specimens figured as $1,4,10$, and 11 are lost); Huddle, 1934, p. 101-102, pl. 8, figs. 29-32; Bischoff and Ziegler, 1957, p. 86, pl. 18, figs. 18-20.

Polygnathus beckmanni Bischoff and Ziegler, 1957, p. 86, pl. 15, fig. 25; Wittekindt, 1965 [1966], p. 632, pl. 1, fig. 19. Polygnathus? variabilis Bischoff and Ziegler, 1957, pl. 18, figs. 8, 9, 13, (young individuals) ; pl. 18, fig. 15 .

Lectotype.-USNM 1305046, the specimen figured by Bryant, 1921, pl. 13, fig. 2; here designated, and figured on pl. 13, figs. $6,12,13$.

Diagnosis.-The high fused carina, with high posterior denticles, the irregular elongate fused nodes, and a deep, circular basal pit are characteristic of this platform element. The keel is high and sharp, and the posterior tip is deflected downward from the essentially straight bryantodontanlike platform, or a twisted nothognathodanlike platform.

Remarks.-This element seems to be a true platform, but may be an ozarkodinan element derived from bryantodontan elements, similar to the nothognathellan and polygnathellan elements. It differs from Polygnathus collieri in the larger basal pit and narrower platform, and it appears less platelike. Young specimens are like $P$.? variabilis Bischoff and Ziegler. Older specimens have broader plates extending the full length. The lectotype of $P$. caelatus has the deflected tip of the plate that characterizes $P$. beckmanni.

Occurrence.-This species has been reported from the $P$. varcus-Zone, $S$. hermanni-cristatus-Zone and the Polygnathus asymmetricus-Zone. C. A. Sandberg (written commun., 1974) reported $P$. caelatus from the Eifelian of Belgium. In New York, it occurs in the Tully Limestone, the North Evans Limestone of Rickard (1964), the Leicester Marcasite Member of the Moscow Formation of Sutton (1951), and the Geneseo Shale, Penn Yan Shale, and Genundewa Limestone Members of the Genesee Formation at the following localities: Gen-4, $\mathrm{Wg}-3, \mathrm{Py}-7, \mathrm{Ph}-7, \mathrm{Cd}-$ 12, Cl-4, Cl-2, Ba-2, At-1, Dp-3, Dp-1, Ed-2, Ed-1, SC-1.$$
\text { Polygnathus collieri n. sp. }
$$

Pl. 9, figs. 20-25; pl. 10, fig. 22; pl. 11, figs, 1-4; pl. 12, figs. $1-3$; pl. 13, fig. 11

Polygnathus caelatus Bryant, 1921, pl. 13, figs. 7, 9, 10, 11 (not figs. 1-6, 8, 11, $12=$ Polygnathus caelatus) ; Seddon, 1970 , p. 57, pl. 15 , figs. $5,6$.

Named for.-Frederick J. Collier who prepared most of the samples collected by W. H. Hass.

Holotype.-USNM 188707 ; 4577-SD.

Material.-About 100 specimens from 9 localities.

Description.-Lanceolate plate with thick rugose, raised rims, deep adcarinal troughs, and high fused carina. Some of the posterior rugae fused to the carina. There is a large free blade with largest denticle at or adjacent to the anterior tip in most specimens. Posterior tip of platform strongly downcurved; keel thin and high at the posterior tip, split anteriorly and extending under the free blade. Basal cavity, at or near the point of arching of the plate, with a small slightly, or distinctly asymmetrical, thick-lipped pit.

Remarks.-This species is quite similar to $P$. robusticostatus, an Eifielian species, in the basal cavity and platform ornamentation, but differs in the free 
blade. The highest denticle in the free blade is at the anterior end in $P$. collieri and near the center in $P$. robusticostatus. $P$. collieri has usually been placed in $P$. caelatus, a variable species. Typical $P$. caelatus has little or no free blade in mature specimens, the platform is asymmetrical, broad, and the ridges irregular. Perhaps $P$. collieri is a subspecies or an extreme variation of $P$. caelatus. I think it wise to separate them at this time. As we learn more about multielement species, it may be placed in synonomy, but now it seems to differ in distribution as well as in the characters previously mentioned.

Occurrence.-P. collieri occurs in New York in the Leicester Marcasite Member of the Moscow Formation of Sutton (1951), the North Evans Limestone of Rickard (1964), and the Penn Yan Shale, Genundewa Limestone, and West River Shale Members of the Genesee Formation at localities: Gen-2, Py-7, Ba-3, At-1, Dp-3, Dp-1, Ed-2, Ed-1, SC-1.

Polygnathus cristatus Hinde

Pl. 9, figs. 11-19; pl. 10, figs. 1-18 (figs. 1, 2, 6, and 9-10 questionably referred to the species)

Polygnathus cristatus Hinde, 1879, p. 366, pl. 17, fig. 11; Branson and Mehl, 1933, p. 147, pl. 11, fig. 10; Ziegler, 1965 b [1966], p. 670-671, pl. 5, figs. 1-4, and 5?, pl. 4, figs. 17-21 (not figs. 22, 23).

Polygnathus caelatus Bryant, 1921, pl. 13, fig. 9 (not pl. 13, fig. 2, the lectotype of $P$. caelatus).

?Polygnathus cristatus Hinde. Wirth, 1967, p. 244, pl. 21, fig. 18.

Holotype. - The specimen figured by Hinde (1879) pl. 17, fig. 11, and Branson and Mehl, 1933, pl. 11, fig. 10.

I examined the holotype in 1967,1968 , and 1974 and am still not certain of the identification. The specimen is embedded in limestone, and the posterior tip of the plate is gone. I concluded, as Kirchgasser (1970) did, that Hinde's type is not the same species as many of the specimens assigned to $P$. cristatus by Bischoff and Ziegler (1957). The characters on the aboral surface of the holotype are unknown and will remain unknown until the holotype is prepared. The plate is relatively thin and is flat in cross section, and the posterior part is arched downward. The carina is composed of nodes, but does not reach to posterior part of the plate. The nodes are arranged in two rows parallel to the carina, and some of them are joined by low ridges. Two nodes at the left of the free blade are joined to form a rostral ridge. The free blade has the highest denticle in the middle.

It can be argued that the holotype of $P$. cristatus is a senior synonym of Ancyrodella rotundiloba Bryant, conspecific with $P$. tuberculatus Hinde, or a separate species. I think it is a separate species having the following characteristics:

Description.- Short elements, with one side of the platform wider than the other. Carina straight with a row of rounded nodes on each side parallel to the carina. Other large round nodes tend to parallel the carina but fuse laterally in large specimens. One or more rostral ridges present. Basal pit large, thick lipped like the basal pit in Ancyrodella. Aboral growth lines coarse and crimp inclined. Large specimens more irregular than small ones.

Remarks. $-P$. cristatus Hinde shares characteristics with Ancyrodella rotundiloba, Polygnathus tuberculatus, and $P$. ectypus, and is somewhat similar to $P$. asymmetricus. The general shape and basal pit of $P$. cristatus suggest that the species should be referred to the genus Ancyrodella. This is not done here because the change would cause needless confusion during the period of time needed to establish multielement nomenclature. The growth series in $P$. cristatus indicates that it is distinct from the similar and related species. In the smallest specimens, the asymmetrical shape of the platform, the incipient rostral ridge, and the regular rows of nodes distinguish this species from $A$. rotundiloba, $P$. ectypus, and $P$. asymmetricus. Some larger specimens, like the one figured on pl. 10, figs. 1, 2, are distinguished from $A$. rotundiloba by the rostral ridges. Other large specimens with irregular or deflected posterior carinae, like those figured on pl. 10, figs. 10,11 , are intermediate between $P$. cristatus and P. tuberulatus.

Bischoff and Ziegler (1956) and Ziegler (1965b) included within the species $P$. cristatus platforms, if they had coarse nodes, with thin oval plate, fine delicate growth lines, and very small basal pits. They allowed a wide variation in the shape of the plate and size of the basal pit as well as in plate thickness. Because of the small basal pit, I prefer to place in $P$. ectypus the specimens with coarse nodes that they place in $P$. cristatus.

In addition to the type of $P$. cristatus, I also examined the specimens identified by Hinde and the specimens identified by Bryant from the North Evans Limestone of Rickard (1964) at the British Museum. My collections add only a few specimens from the type locality. The best specimens in my collections are from the Crosby Sandstone Member of the Standish Formation as used by Torrey and others (1932) and the Genundewa Limestone Member.

Occurrence.-This species occurs in the Leicester Marcasite Member of Sutton (1951), North Evans Limestone of Rickard (1964), Geneseo Shale Mem- 
ber, Genundewa Limestone Member, and Crosby Sandstone Member as used by Torrey and others (1932) in the Genesee Formation in New York at the following localities: I-2, I-3, Ov-12, Py-14, $\mathrm{Py}-15, \mathrm{Cd}-12, \mathrm{Cl}-2, \mathrm{Dp}-1, \mathrm{Dp}-3, \mathrm{Ed}-1$, and $\mathrm{SC}-1$.

In Germany, this species is reported by Ziegler (1965b) from the section at Koppen and near Giebringhausen, and at Rhenert near Bonzel in the Polygnathus hermanni-P. cristatus and Lower $P$. asymmetricus zones.

Polygnathus decorosus Stauffer

Pl. 17, figs. 13-15

For synonomy see Klapper, Philip, and Jackson, 1970, p. 652.

Lectotype.-The specimen illustrated by Stauffer, 1938, pl. 53, fig. 6, Univ. Minnesota B 4960 selected by Huddle, 1970.

Diagnosis.-Units with a narrow, symmetrical platform with nodes, upraised rims, and a free blade as long as the plate. Basal pit at or next to the anterior end of the plate. Geniculation points are opposite, and the anterior trough margins are concave upward.

Occurrence.-In New York, this species occurs in the West River Shale Member (Py-7) of the Genesee Formation and in the Tully Limestone at Gage Gully $(\mathrm{Cd}-12)$. Questionably in the Penn Yan Shale (Ba-5, Gen-5) and Ithaca Members (I-3) of the Genesee.

\section{Polygnathus dengleri Bischoff and Ziegler}

$$
\text { Pl. 6, figs. 15-23 }
$$

Polygnathus dengleri Bischoff and Ziegler, 1957, p. 87-88, pl. 15 , figs. 14, 15, 17-24; pl. 16, figs. 1-4; Krebs, 1959, pl. 1, figs. 1, 4, 5; Bartenstein and Bischoff, 1962, pl. 4, figs. 37-41; Ziegler, 1965b, [1966] p. 671-674, pl. 6, figs. 1-6; Clark and Ethington, 1967, p. 60, pl. 7, figs, 3, 8; Müller and Clark, 1967, p. 916, pl. 115, figs. 3a, b, 7a-c; Pölsler, 1969 , p. 421, pl. 4, figs. 13, 14; Kirchgasser, 1970, p. $348-349$, pl. 63 , fig. 2 , pl. 64 , fig. 4, pl. 66, fig. 2 .

Remarks. - The narrow symmetrical pointed plate with upturned rims and a lack of nodes near the carina are characteristic of this platform element. Also distinctive is the large elongate, pointed basal cavity shaped like the platform. The keel is high and the plate thicker than young specimens of $P$. asymmetricus.

There seems to be a gradation between several types of platforms in the Lower Polygnathus asymmetricus-Zone, as pointed out by Ziegler (1965b). Intermediate specimens are difficult to assign to species.

Occurrence.-In New York, this species occurs in the North Evans Limestone of Rickard (1964) and the Penn Yan Shale, Genundewa Limestone, and
West River Shale Members of the Genesee Formation at localities: $\mathrm{Ov}-10, \mathrm{Ph}-5, \mathrm{Ph}-1, \mathrm{Nap}-4, \mathrm{Nap}-5, \mathrm{Cd}-$ 7, Cd-5, Cl-5, Cl-4, Cl-3, Cl-2, Ba-3, At-1, Dp-3, Dp-1, Ed-2, Ed-1, SC-1.

\section{Polygnathus dubius dubius Hinde Pl. 18, figs. 13-18}

Remarks.-For description and synonomy see Huddle, 1970.

Occurrence.-In New York, the species occurs in all members of the Genesee Formation at the following localities: Dy-10, I-3, I-2, Gen-5, Gen-4, Gen-2, Ov-10, Ov-12, Wg-1, Wg-3, Wg-13, Py-15, Py-14, $\mathrm{Ph}-5, \mathrm{Ph}-1, \mathrm{Cd}-12$, Nap-4, Nap-5, Cd-5, Cd-7, $\mathrm{Hy}-6, \mathrm{Hy}-2$, Cl-5, Cl-4, Cl-3, Cl-2, Ba-5, Ba-3, Ba2, At-1, Dp-3, Dp-1, Ed-1, Ed-2, SC-1.

$$
\text { Polygnathus dubius frons n. subsp. }
$$$$
\text { Pl. 15, figs. 22-27 }
$$

Name.-From Latin frons meaning leaf. Noun in apposition.

Holotype.-USNM 188767 ; USGS 7620-SD.

Material.-About 900 specimens from 15 localities.

Diagnosis.-Small asymmetrical polygnathid with the outer platform wider than the inner platform, deep adcarinal troughs, usually swollen at the anterior margins, and a tendency to develop rostral ridges. Basal pit anterior to the midpoint of the plate.

Remarlss.-Differs from $P$. dubius dubius in the tendency to form rostral ridges with swollen anterior margins and in the anterior pinch of the plate. The subspecies intergrade, and many specimens are difficult to place. In collections of 25 or more specimens, they can be separated on the basis of the dominant characters of the group of specimens. If most of the specimens have rostral ridges, anteriorly pinched plate, or swollen anterior margins of the plate, I refer all the specimens to $P$. dubius frons. The average specimen changes with time from $P$. $d u$ bius frons in the Leicester Marcasite Member of the Moscow Formation of Sutton (1951) and the Geneseo Shale Member of the Genesee Formation to $P$. dubius dubius high in the Penn Yan Shale and Genundewa Limestone Members of the Genesee Formation.

This subspecies differs from $P$. pseudofoliatus and species in the $P$. varcus group by the better development of the plate, nodose plate ornamentation, and the position of the basal pit.

Occurrence.-P. dubius frons occurs in the Leicester Marcasite Member of the Moscow Formation of 
Sutton (1951) and the Geneseo Shale Member of the Genesee Formation at localities: Dp-1, Dp-3, At-1, $\mathrm{Cd}-12, \mathrm{Ph}-7$, and questionably at Gen-5. Two specimens from $\mathrm{Ba}-5$, and four specimens at $\mathrm{Cl}-2$ from the Penn Yan Shale Member of the Genesee are questionably assigned to the subspecies.

Polygnathus ectypus Huddle

Pl. 7, figs. 16-18; pl. 9, figs. 1-3, 6-10

Polygnathus ectypa Huddle, 1934, p. 103, pl. 8, fig. 38.

Polygnathus cristata sensu Bischoff and Ziegler, 1957, p. 8687 , pl. 15, figs. $1-7,10$; pl. 17, figs. $12-13$; Orr and Klapper, 1968, pl. 139, figs. 1-4, 8, 9; Kirchgasser, 1970, p. $346-347$, pl. 63 , figs. $3,7,10$; Orr, 1971 , p. 48 , pl. 6 , figs. $1,2$.

?Polygnathus cristata sensu Bischoff and Ziegler. Flajs, 1966, pl. 25, fig. 4.

Holotype.-Indiana University Colln. 1799, Lower New Albany Shale, Speed, Clark County, Ind.

Diagnosis.-Platform element with a thin flat plate, oval shape, coarse nodes, and a small round pit in the thin sharp keel at the point of plate arching.

Remarks.-It differs from $P$. cristatus in the thin plate and very small basal pit in a thin keel. In Polygnathus cristatus, the pit is large, asymmetrical with thick lips and a trough extending under the blade with sharp thick ridges on both sides; the growth lines are coarser.

$P$. ectypus has coarser nodes and a longer free blade than does $P$. asymmetricus ovalis. In New York, the coarsely noded $P$. ectypus appears earlier than $P$. asymmetricus ovalis, and perhaps there is a gradual reduction in the size of nodes as one taxon grades into the other.

Occurrence.-In New York, this species occurs in the Leicester Marcasite Member of Sutton (1951) and the Penn Yan Shale and Genundewa Limestone Members of the Genesee Formation at Gen-2, Ov-10, Ov-12, Wg-3, Ph-1, Cl-3, At-1, Dp-3, Dp-1, Ed-2, Ed-1. It also occurs in the Traverse Group, Antrim Shale in Michigan, and New Albany Shale in Indiana, the Alto Formation in Illinois, the Marble Cliff Beds in England, and the Obere Stringocephalen Stufe in Germany.

\section{Polygnathus linguiformis Hinde \\ Polygnathus linguiformis linguiformis Hinde form gamma of Bultynck \\ Pl. 15, figs. 9-21}

Polygnathus linguiformis linguiformis Hinde form gamma of Bultynck, 1970, p. 126-127, pl. 11, figs. 1-6, pl. 12, figs. 1-6; Klapper, 1971 , p. 64 , pl. 2, figs. $18,19,22-40$, pl. 3 , figs. 13-15.

Holotype.-British Museum A 4316, Hinde, 1879, pl. 17, fig. 15. A gerontic specimen.
Remarks. $-P$. linguiformis s.s. is a well-known form and has been described many times. Bultynck (1970) has recognized three forms: the typical form, which he designates gamma, and two others designated alpha and beta. Klapper, 1971, has proposed a new subspecies, $P$. linguiformis cooperi, and has recognized the two subspecies proposed by Wittekindt, $P$. linguiformis mucronatus, and $P$. linguiformis transversus.

Occurrence.-In New York, this morphotype occurs in the Union Springs Shale Member of the Marcellus Shale (Hamilton Group), Tully Limestone, and the Genesee Formation as high as the Genundewa Limestone Member. It occurs at the following localities: Gen-5, $\mathrm{Ph}-6, \mathrm{Ph}-7, \mathrm{Cd}-7, \mathrm{Cd}-12$, $\mathrm{Hy}-6, \mathrm{Cl}-5$, Cl-4, Cl-3, Cl-2, Ba-3, Ba-2, At-1, Dp-3, Dp-1, Ed-2, Ed-1, SC-1.

\section{Polygnathus linguiformis linguiformis Hinde, form delta, n. form} Pl. 15, figs. 1-8

Polygnathus linguiformis linguiformis Hinde form gamma of Bultynck, 1970 , pl. 11, figs. 4, 6, pl. 12, figs. 4, 6, 7 [not pl. 9, figs. 8-11 $=P$. linguiformis cooperi Klapper; nor pl. 10 , figs. $1,2,5$; pl. 11 , figs. $1,2,3,5$; pl. 12 , figs. $1,2,3,5,9=P$. linguiformis linguiformis form gamma]. Polygnathus linguiformis Hinde. Rhodes and Dineley, 1957, pl. 38, fig. 3 [not pl. 37, figs. 17-19] ; Bischoff and Ziegler, 1957 , pl. 1 , figs. 4 and 13 , pl. 16 , figs. 32,33 , pl. 17 , figs. $5-8$.

Diagnosis.-This form is distinguished by sharp coarse ribs that indent the margin of the upraised outer flange and by a narrow finely ribbed posterior tip or tongue. The basal cavity is large, and the keel is split by a strong groove anteriorly.

Remarks.-There are specimens intermediate between forms gamma and delta, but form delta could be raised to the rank of subspecies. Young specimens are like forms alpha and beta and these three forms may represent a lineage. The form delta is distinguished by the increased size of the adults and the long narrow tongue with more numerous cross ribs. The changes from alpha to delta include increasing asymmetry, involving increase in size and raising the outer flange. This results in the carina being closer to the interior margin of the plate.

A few specimens from the Tully have transverse anterior ridges like $P$. linguiformis transversus and nearly symmetrical forms like $P$. linguiformis $m u$ cronatus. Some specimens do not have a strongly raised flange, and a few have nodes instead of ribs on the outer anterior platform. There seems to be considerable variation in these forms. Precise age assignment on the basis of these forms will be difficult and perhaps questionable. 
Many of the specimens from the North Evans Limestone of Rickard (1964) and from the Genundewa Limestone Member of the Genesee Formation retain the basal plate. They cannot have been transported far nor abraded strongly and still have retained the base, even though they were probably sorted by currents.

Occurrence.-This form occurs in the Couvinian in Belgium. In New York, it is found in the Windom Member of the Moscow Shale, the Tully Limestone, and the Genesee Formation as high as the Genundewa Limestone Member at localities: Gen-5, Ph-7, Cd-12, Dp-3, Dp-1, Ed-2, Ed-1, SC-1.

"Polygnathus norrisi" Uyeno

$$
\text { Pl. 19, figs. 4, } 5
$$

Polygnathus norrisi Uyeno, 1967, p. 10-11, pl. 2, figs. 4, 5; Norris and Uyeno, 1972, p. 215, pl. 3, fig. 15; Uyeno, 1974, p. 39-40, pl. 5, figs. 3, 6 .

Remarks.-Uyeno (1974, p. 39-40) reported a few specimens from three formations in Canada and mentioned similar specimens reported by Helms (1959) and Shaffer (1963). In addition to the specimen from the Hibbard collection figured on pl. 19, figs. 4, 5, I have found three specimens like $P$. norrisi. None of these specimens came from the same collection (two from the same locality).

I think that these are pathologic specimens of Polygnathus dubius dubius and Bryantodus retusus and that $P$. norrisi is not a valid species.

Occurrence.-In New York, one specimen each from the following localities: $P$. dubius dubius: in the Genesee Formation, Genundewa Limestone Member at Taunton Gully (Cl-2), USGS 4586-SD; Genundewa Limestone Member at Elevenmile Creek, (At-1) USGS 4586-SD; Penn Yan Shale Member at Elevenmile Creek, USGS 8972-SD. Bryantodus retusus: Lodi Limestone of Clarke (in Lincoln, $1895)$ at Mill Creek (Ov-10), USGS 6768-SD; Eighteenmile Creek, (Ed-1) North Evans Limestone of Rickard (1964), USGS 8123-SD; Leicester Marcasite Member of Moscow Formation of Sutton (1951), at Eighteenmile Creek, USGS 4536-SD.

\section{Polygnathus ordinatus Bryant}

Pl. 13, figs. 14-18; pl. 14, figs. 6-19; pl. 16, figs. 3-20

For synonomy and description see Huddle (1970).

Remarlis.-Some broad forms intermediate between $P$. ordinatus and $P$. peracutus are here included with $P$. ordinatus because of the shape of the plate and the basal cavity. Ziegler (1965b) [1966] figured several similar specimens (pl. 4, figs. 5, 6, 9, 10, 11, 14-16 and $P$. rugosa pl. 5, fig. 14) that I would place in $P$. ordinatus. As Ziegler (1965b)
[1966] emphasized, conodont evolution was very rapid during the late Middle and early Late Devonian and many intermediate forms exist.

The specimen figured on pl. 16, figs. 17, 18, has a large callus formed from the basal plate.

Occurrence.-Genesee Formation at localities: $\mathrm{Ov}-10, \mathrm{Wg}-3, \mathrm{Ph}-7, \mathrm{Cd}-7, \mathrm{Cl}-4, \mathrm{Cl}-3, \mathrm{Cl}-2, \mathrm{At}-1$, $\mathrm{Dp}-3, \mathrm{Dp}-1, \mathrm{Ed}-2, \mathrm{Ed}-1, \mathrm{SC}-1$.

\section{Polygnathus pennatus Hinde Pl. 12, figs. 4-6}

Remarks.-For description and synonomy see Huddle (1970).

Occurrence.-In New York, the species occurs in all the members of the Genesee Formation at the following localities: Dy-10, I-3, I-2, Gen-2, Ov-10, Ov-12, Wg-13, Py-15, Py-14, Py-7, Ph-1, Cd-12, $\mathrm{Nap}-5, \mathrm{Nap}-4, \mathrm{Cd}-5, \mathrm{Cl}-5, \mathrm{Cl}-4, \mathrm{Cl}-3, \mathrm{Cl}-2, \mathrm{Ba}-3$, $\mathrm{Ba}-2, \mathrm{At}-1, \mathrm{Dp}-3, \mathrm{Dp}-1, \mathrm{Ed}-2, \mathrm{Ed}-1, \mathrm{SC}-1$.

Polygnathus peracutus Bryant

Pl. 11, figs. 5-7; pl. 13, figs. 7, 8; pl. 16, figs. 1, 2

Polygnathus peracutus Bryant, 1921, p. 25, pl. 10, fig. 12.

P. peracuta Bryant. Huddle, 1934, p. 97, pl. 8, fig. 8; Bischoff and Ziegler, 1957, p. 95, pl. 16, fig. 29; Orr, 1964, p. 20, pl. 4, figs. 3, 4; Seddon, 1970, p. 61, pl. 14, figs. 6-8.

Schmidtognathus peracuta (Bryant). Ziegler, 1965b [1966], p. 668 , pl. 1, figs. 1-10.

non Polygnathus peracuta? Branson and Mehl, 1933, p. 150, pl. 11, fig. 4 .

Holotype.-USNM 135036, the specimen figured by Bryant, 1921, pl. 10, fig. 12, from the "Conodont Bed" (North Evans Limestone of Rickard, 1964) at Eighteenmile Creek, N. Y.

Diagnosis.-Elements with a thin elongate triangular plate arched just anterior to basal cavity and ornamented with distinct round nodes on the oral surface in two to four rows parallel with the carina. Plate flat or twisted. Basal cavity thick lipped with a deep trough extending under the blade. Some specimens have a distinctly asymmetrical rim of the basal cavity, and the outside rim of the basal trough may be higher than the inside rim. The attachment area of the base tends to be concave.

Remarls. - The material from the Houy Formation in Texas, reported by Seddon (1970, p. 61), and the material from New York suggest that the asymmetrical rim of the pit is a variable character and is shared by other species referred to Polygnathus. The assignment of peracutus to Schmidtognathus is thus questionable, and I have placed it in Polygnathus.

Typical $P$. peracutus is distinguished from $P$. ordinatus by the thin, flat, triangular plate with dis- 
tinct nodes. $P$. ordinatus has a more elliptical, narrow thick plate with fused nodes in typical specimens. However, many specimens are difficult to assign to species, and the two species intergrade.

Occurrence.-Leicester Marcasite Member of Moscow Formation of Sutton (1951), the North Evans Limestone of Rickard (1964), and the Penn Yan Shale, Genundewa Limestone, and West River Shale Members of the Genesee Formation at localities: Gen-5, Ph-7, Cd-12, Cd-7, Cl-2, Ba-2, At-1, Dp-3, Dp-1, Ed-1.

Polygnathus rhenanus marijae n. subsp.

Pl. 17, figs. 10-12, 16-27; pl. 18, figs. 1-12

Name.-Named for Marija Balanc who prepared many of the conodont samples.

Holotype.-UMMP 60867. North Evans Limestone of Rickard (1964) in Genesee Formation, Amsdell Creek, N.Y. R. R. Hibbard collection.

Material.-About 300 specimens from 7 localities.

Diagnosis.-A subspecies of $P$. rhenanus Klapper, Philip, and Jackson, 1970, with a small, asymmetrical plate with geniculation points opposite deep unequal adcarinal troughs, nodose upturned platform margins, and a prominent basal cavity at the junction of the plate and free blade. Free blade about two-thirds the length of the conodont. Aboral view shows a distinct constriction behind the inflated adcarinal troughs.

Remarks.-This subspecies differs from the nominate subspecies in the nodose posterior platform margins and larger size of the platform. It is more asymmetric, and the basal cavity is more anterior than in $P$. xylus.

Occurrence.-In New York, this subspecies occurs in the Windom Member of the Moscow Shale, the Tully Limestone, the Leicester Marcasite Member of Moscow Formation of Sutton (1951), the North Evans Limestone of Rickard (1964), and the Geneseo Shale and Genundewa Limestone Members of the Genesee Formation at localities: $\mathrm{Ph}-7, \mathrm{Cl}-5$, Cd-12, Ba-2, Dp-1, Ed-1, Ed-2, SC-1.

Polygnathus aff. P. trigonicus Bischoff and Ziegler Pl. 17, figs. 38-40

Polygnathus trigonicus Bischoff and Ziegler, 1957, p. 97-98, pl. 5, figs. 1-6.

Remarks.-Three specimens similar to $P$. trigonicus were found in the collections, one each from three localities and three stratigraphic positions. The specimens are characterized by large round nodes, sharp-pointed posterior tip of the plate, and a large basal cavity.
Occurrence.-In New York in the Moscow Shale (Ba-2), the Tully Limestone $(\mathrm{Cd}-12)$, and the Marathon Sandstone Member of the Ithaca facies of Caster (1933), and in the Ithaca Member of the Genesee Formation.

Polygnathus tuberculatus Hinde

Pl. 11, figs. 8-14; pl. 12, figs. 19-21; pl. 13, figs. 9, 10

Polygnathus tuberculatus Hinde, 1879, p. 366, pl. 17, fig. 9 (not fig. 10); Grabau, 1899, p. 156, fig. 40; Bryant, 1921, p. 25, pl. 12, figs. 7-9; Glenister and Klapper, 1966, p. 799; Branson and Mehl, 1933, p. 148, pl. 11, fig. 2 (not 9). Polygnathus bryanti Huddle, 1934, p. 97, figs. 9, 10; Wittekindt, 1965, p. 632-633, pl. 1, figs. 22-25.

Lectotype.-Bryant, 1921, p. 25-26, British Museum Natural History A-4241, figured by Hinde 1879, pl. 17, fig. 9, and Branson and Mehl, 1933, pl. 11, fig. 2. Type from the North Evans Limestone of Rickard (1964), Eighteenmile Creek, New York.

Diagnosis.-This platform species is characterized by the short, broad, platform and the abrupt deflection of the posterior part of the carina and the large thick-lipped basal cavity.

Remarks.-I have examined Hinde's, Bryant's, and my own types, and I am sure that they are the same species. The large thick conodont basal plate is retained on many specimens.

This species could be referred to Schmidtognathus because of the large asymmetrical basal cavity, coarse ornamentation, and thick plate, but it lacks the elongate plate of the other species referred to that genus. The shape of the basal cavity and pit is similar to that of Ancyrodella also, and may be ancestral to the Genesee species.

Occurrence.-In New York, this species occurs in the Windom Member of the Moscow Shale, the Leicester Marcasite Member of the Moscow Formation of Sutton (1951), and the North Evans Limestone of Rickard (1964) at localities: $\mathrm{Ba}-2, \mathrm{Dp}-3$, Ed-2, Ed-1, SC-1.

\section{Polygnathus "V"}

Pl. 17 , figs. $28-31$

Remarks.-Nine broken specimens from Gage Gully (Cd-12) Voorhys Gully (near $\mathrm{Ph}-1$ ), and Bellona $(\mathrm{Ph}-7)$ appear to belong in the Polygnathus varcus group, but their plates are better developed and the plate ornamentation is stronger than in other species in the group. The length of the free blade is unknown.

$$
\text { "Pseudopolygnathus" }
$$

Remarks.-Some specimens of $P$. dubius or a similar form have a distinct callus on the underside of the element. Others have greatly thickened lips 
of the basal cavity which extends on both sides of the trough along the keel under the whole platform. This suggests a structure characteristic of the genus Pseudopolygnatus in the Late Devonian and Early Mississippian. The thickened rims seem to be the result of a change in structure of the basal plate and perhaps a change in composition whereby the basal plate looks like the main element and is firmly joined. Perhaps this is the origin of the thickened keel and lips of the basal cavity in Pseudopolygnathus.

Occurrence.-Specimens of "Pseudopolygnathus" from the Leicester Marcasite Member of the Moscow Formation of Sutton (1951) at Cazenovia Creek (Dp-1).

\section{BLADE ELEMENTS}

Blade elements are rare in the Genesee Formation, as shown in the tables. Only a few broken specimens have been found, and they are questionably identified. The other elements associated in apparatus genera and species of Pandorinellina and Ozarkodina by Klapper and Philip (1971, 1972) have not been recognized.

\section{PANDORINELLINA Hass 1957}

Pandorinellina Hass in Müller and Müller, 1957, p. 1083.

$$
\text { Pandorinellina insita (Stauffer) }
$$$$
\text { Pl. 19, figs. } 10-15
$$

Pandorina insita Stauffer, 1940, p. 429, pl. 59, figs. 23, 25.

Pandorina gratiosa Stauffer, 1940, p. 428, pl. 59, figs. 18$20,24$.

Spathognathodus gratiosus (Stauffer). Youngquist, 1947, p. 111, pl. 26, fig. 1.

Ctenognathus (Pandorinellina) insita (Stauffer). Müller and Müller, 1957, p. 1083, pl. 142, figs. 2, 3.

Ozarkodina insitus (Stauffer). Klapper and Philip, 1971, fig. 1. Multielement species.

Pandorinellina insita (Stauffer). Klapper and Philip, 1972, p. 99.

Lectotype.-Platform element; specimen figured by Stauffer, 1940, pl. 59, fig. 25, designated by Müller and Müller, 1957.

Material.-Three broken specimens.

Remarks.-Only one of the specimens is complete enough to tentatively identify with $P$. insita; the other two specimens are like the best preserved specimen in the character of the basal cavity. The basal cavity is similar to that in specimens here called Spathognathodus sannemanni, but lacks the basal expansion and nodes on the expansion.

Occurrence.-Marathon Sandstone Member of the Ithaca facies of Caster 1933, Ithaca Member of the Genesee Formation, Williams Brook (I-2).
SPATHOGNATHODUS Branson and Mehl 1941b

Spathognathodus sannemanni Bischoff and Ziegler Pl. 19, figs. 6-9

Spathognathodus sannemanni Bischoff and Ziegler, 1957, p. 117-118, pl. 19, figs. 15, 19-23, 25.

Spathognathodus sannemanni sannemanni Bischoff and Ziegler. Ziegler, 1958, p. 72, pl. 9, fig. 15; Krebs, 1959 pl. 1, fig. 10; Bartenstein and Bischoff, 1962, p. 52, pl. 5, figs. 6,7 ; Pollock, 1968, p. 440, pl. 63 , figs. 10,11 ; Schulze, 1968, p. 226-227, pl. 20, figs. 25.

Remarks.-The figured specimens are from the R. R. Hibbard collection at the University of Michigan Paleontology Museum. They came from the North Evans Limestone of Rickard (1964), Genesee Formation at Amsdell Creek, N.Y. Other collections contain only broken specimens assigned to the species on the basis of the shape of the basal cavity and the nodes on the basal expansion.

Occurrence.-Leicester Marcasite Member of the Moscow Formation of Sutton (1951) at localities $\mathrm{Ph}-7$, and $\mathrm{Dp}-3$; Geneseo Shale Member of the Genesee at $\mathrm{Ph}-7$; and Penn Yan Shale Member of the Genesee at Dp-1.

$$
\begin{gathered}
\text { Spathognathodus semialternans Wirth } \\
\text { Pl. 19, figs. 16-21 }
\end{gathered}
$$

Spathognathodus semialternans Wirth, 1967, p. 235, pl. 23, figs. $6-10$, figs. $14 a, b$.

Polygnathus varcus Stauffer. Wittekindt, 1965 [1966], pl. 3, figs. 8, 9 (not pl. 3, figs. 5-7,=P. varcus? not fig. $10=P$. timorensis fide Klapper, Philip, and Jackson 1970).

Material.-12 specimens.

\section{Spathognathodus aff. S. strigosus (Branson and Mehl)} Pl. 19, figs. 22-25

Spathodus strigosus Branson and Mehl, 1934a, p. 187, pl. 17, fig. 17, [see S. gradatus (Younquist) 1945. Mound, 1968 , p. 514, for synonomy].

Remarks. - The fragments found suggest identification with $S$. strigosus on the basis of the shape of the anterior bar and the character of the basal cavity and basal expansion. No specimen is complete enough to be sure of the identification. I know of no reason why the older name $S$. strigosus should not be used instead of $S$. gradatus.

Occurrence.-Leicester Marcasite Member of the Moscow Formation of Sutton (1951) (Dp-1), North Evans Limestone of Rickard (1964) (Ed--1, Ed-2) ; Geneseo Shale (Ph-7), and Genundewa Limestone (Cl-3, At-1, Ed-2, Ed-1) Members of the Genesee Formation and the Crosby Sandstone Member of the Standish Formation as used by Torrey and others (1932) (Py-15) in the Ithaca Member of the Genesee Formation.

Remarks.-The specimens from Tully Limestone at Tinker Falls (Tu-2) are associated with Phar- 
ciceras in the Polygnathus varcus Zone. Wirth described the species from collections of the highest Givetian in Spain near the border with France. That the types are somewhat older than the specimens from New York is suggested by the occurrence of Polygnathus dubius, $P$. cristatus, and $P$. dengleri in the overlying samples (Lowermost $P$. asymmetricus Zone). The specimens from New York questionably referred to as $S$. semialternans seem to have a smaller basal expansion and one that does not extend to the posterior tip. The specimen from the Crosby Sandstone Member of the Standish Formation as used by Torrey and others (1932) lacks the alternation of denticles but generally it is similar. All specimens assigned to this species are similar to $P$. varcus in the lateral view; possibly, they are immature specimens or ones that failed to develop a platform. The pattern of denticulation and the downwarp of the posterior tip is also similar to $P$. varcus.

\section{OZARKODINAN ELEMENTS BRYANTODUS Bassler 1925}

Bryantodus Bassler, 1925, p. 219; Ulrich and Bassler, 1926, p. 21 ; Hass, 1962, p. W55-56; Huddle, 1968, p. 9.

Subbryantodus Branson and Mehl, 1934b, p. 285.

Type species.-Bryantodus typicus Bassler, 1925, by original designation.

Diagnosis.-Robust ramiform conodonts with a thickened bar, small round basal cavity, prominent lateral or aboral attachment area. Ledges may be present on both sides of the bar, and the denticles may be fused and flattened or discrete and rounded.

Remarks.-There are no clear guidelines to the limits of variation of species of Bryantodus or indeed any bar conodonts. Partly, this fact is due to lack of study because these conodionts generally are insignificant in biostratigraphic studies. It is also due to the known variation, abundance of available names, and lack of large collections with unbroken specimens. In the New York collections reported here, there are a fair number of unbroken specimens of Bryantodus. The best collections are from the North Evans Limestone of Rickard (1964) and the Genundewa Limestone Member of the Genesee Formation. The most abundant of these species are $B$. colligatus and $B$. retusus from the Genesee Formation; they are replaced by $B$. typicus and $B$. nitidus in the Sonyea Formation and younger formations.

Young specimens of Bryantodus are easily confused with species of Ozarkodina. Growth series for both $B$. retusus and $B$. colligatus show the change from a thin arched bar to the thickened bars of adult forms. Aberrant forms of both species show a tendency to form a plate at one end of the bar. The growth series suggests that Bryantodus was derived from Ozarkodina and gave rise to Polygnathellus and possibly to other platform genera. Probably, some species of Bryantodus are the platform elements of a multielement species.

\section{Bryantodus? aversus (Stauffer) \\ Pl. 29, figs. 1-4; pl. 30, figs. 18, 19}

Prioniodina aversa Stauffer, 1938, p. 439, pl. 52, fig. 3; Bischoff and Ziegler, 1957, p. 106, pl. 20, fig. 24.

$P$. cf. P. aversa Bischoff and Ziegler, 1957, pl. 20, fig. 23

Bryantodus grandis Bischoff and Ziegler, 1957, p. 48-49, pl. 20 , figs. 21, 22, 25, 26.

Diagnosis.--Element characterized by a twisted heavy bar, rounded denticles, and round basal cavity in the broad basal area. There is a tendency to develop a platform. Denticles nearly vertical as is typical of aversiform elements. No prominent cusp.

Description.-Thick twisted bar, dark colored, nearly opaque with a broad base and lateral expansion forming an incipient plate. "Plate" may be ornamented by granules or pustules. Basal cavity round and deep with grooves extending into the base of bars. Basal area has strong growth lines and may be inverted slightly. Cusp not prominent or indistinguishable. Denticles rounded, more or less fused on the posterior bar, and separated on the anterior bar. White matter diffuse mainly near the tips of the denticles and cusp.

Remarks.-I have assigned B.? aversus to Bryantodus questionably. This bar unit does not fit into any of the form genera and is similar to species of Prioniodina, Nothognathella, Polygnathellus, and Bryantodus. In assigning the species to Bryantodus, I stress the similarity to $B$. colligatus. The assignment of this species to a form species is not a significant problem because it belongs to a multielement apparatus yet to be established.

Occurrence.-Tully Limestone and Genesee Formation at localities: Gen-5, Py-7, Nap-4, Nap-5, Cd-12, Cl-3, Cl-2, At-1, Dp-3, Dp-1, Ed-2, Ed-1. Upper Olentangy Shale of Ohio and the upper Givetian of Germany.

Bryantodus aff. B. biculminatus Bischoff and Ziegler

Bryantodus biculminatus Bischoff and Ziegler, 1957, p. 47, pl. 13 , figs. $7,8,9$.

B. cf. B. biculminatus Bischoff and Ziegler. Philip, 1966, p. 153, pl. 2, figs. 13,17 ; Wolska, 1967, p. 375-376, pl. 2, fig. 11.

Diagnosis.-Element strongly bowed, with short anterior bar. Denticles may alternate in size, oval in cross-section, and with diffuse white matter con- 
fined to the upper part of the bar and denticles. They are not apparently inserted as in $B$. retusus. Broken specimens not figured.

Occurrence.-In the Tully Limestone and Genesee Formation at localities: $\mathrm{Py}-7, \mathrm{Ph}-7, \mathrm{Cd}-12, \mathrm{Nap}-4$, Cl-2, At-1, Dp-1.

\section{Bryantodus colligatus (Bryant) \\ Pl. 22, figs. 11-24; pl. 26, fig. 3}

Prioniodus colligatus Bryant, 1921, p. 17, pl. 3, figs. 1, 2, 4, pl. 5, fig. 6, pl. 7, fig. 2, 6 (not pl. 6, fig. 8).

Polygnathellus colligatus (Bryant). Ulrich and Bassler, 1926, p. 53; Holmes, 1928, p. 16.

Bryantodus colligatus (Bryant). Bischoff and Ziegler, 1957, p. 47, pl. 19, fig. 39; Müller and Clark, 1967, p. 910, pl. 117 , figs. 2,9 .

B. cf. B. colligatus Bischoff and Ziegler, 1957, p. 48, pl. 19, fig. 42; Philip, 1966, p. 153, pl. 2, fig. 20.

Prioniodus cristatus Bryant, 1921, p. 20, pl. 3, fig. 9, pl. 6, fig. 7.

Prioniodus obstusus Bryant, 1921, p. 20, pl. 3, fig. 6, pl. 6, fig. 1.

Prioniodus spatulatus Bryant, 1921, p. 18, pl. 8, fig. 9.

Bryantodus multidens Ulrich and Bassler, 1926, p. 22, pl. 6, fig. 15 (not fig. 16); Huddle, 1934, p. 67, pl. 2, figs. 1-3; Youngquist, Hibbard, and Reimann, 1948, p. 51, pl. 15, fig. 15; Bischoff, 1956, p. 122, pl. 10, fig. 1, 2; Bischoff and Ziegler, 1957, p. 50; Ethington and Furnish, 1962, p. 1265 ; Ethington, 1965 , p. 571; Müller and Clark, 1967, p. $910-911$, pl. 117 , fig. 11 .

Polygnathollus curvatus Ulrich and Bassler, 1926, p. 54, pl. 1 , fig. 4.

Bryantodus germanus Ulrich and Bassler. Clark and Ethington, 1967, p. 31, pl. 2, fig. 11.

?Bryantodus attentuatus Branson and Mehl, 1934a, p. 219, pl. 16, fig. 4.

Bryantodus coalescenoides Huddle, 1934, p. 72, pl. 3, fig. 8; Olivieri, 1965, p. 9, pl. 3, fig. 7.

Bryantodus robustus Youngquist, Hibbard, and Reimann, 1948 , p. 51, pl. 15, fig. 1.

Bryantodus solidus Stewart and Sweet, 1956, p. 265, pl. 34, fig. 8.

?Bryantodus grahami Stauffer. Clark and Ethington, 1967, p. 32 , pl. 3, fig. 8 , juvenile?

Bryantodus sp. A Youngquist, 1947, p. 98, pl. 24, fig. 6 .

Bryantodus sp. B Youngquist, 1947, p. 99, pl. 24, fig. 12.

Bryantodus sp. C Youngquist, 1947, p. 99, pl. 24, fig. 23.

Bryantodus? sp. Youngquist, 1947, p. 99, pl. 25, fig. 24.

Bryantodus sp. A Hass, 1956, pl. 4, fig. 23.

Bryantodus sp. a Bischoff and Ziegler, 1957, p. 54, pl. 19, fig. 44.

Bryantodus sp. b Bischoff and Ziegler, 1957, p. 54, pl. 19, fig. 38.

Bryantodus sp. Panseri and Barsotti, 1959, p. 155, pl. 2, fig. 5.

Lectotype.-The specimen figured by Bryant, 1921, pl. 5, fig. 10, USNM 142768. Here designated and refigured (pl. 26, fig. 3). This is the only remaining type specimen; the others are lost.

Diagnosis.-A species of Bryantodus with very finely pitted prominent ledges on both sides of the bar, and numerous, flattened, closely appressed denticles and cusp. The bar may be nearly straight or arched and bowed, the cusp may be indistinct or prominent, and a triangular expansion at the base of the cusp may be present. White matter diffuse, rarely extending into the bar.

Remarks.-As suggested by the synonomy list, this species is a variable one, and abnormal specimens have been described as new species. Young specimens have thin bars and are similar to species of Ozarkodina. Not all can be distinguished from the young of other species of Bryantodus. In large collections, it is difficult to separate $B$. colligatus from $B$. retusus because the range of variation in the two species overlaps. The matte surface of the ledges and the strong outer ledge generally distinguishes $B$. colligatius as well as does the close spacing and flattening of the denticles. The triangular expansion below the cusp is more common in $B$. retusus than in $B$. colligatus, but it is present in both. Some specimens have a downfold of the flange near the cusp. The average specimen of $B$. colligatus is nearly straight, but strongly arched and bowed specimens are present in many collections. Commonly the anterior bar is bowed inward.

Possibly, the intergrading species of $B$. colligatus and $B$. retusus were part of the apparatus of the same conodont-bearing animal. I think it unlikely because of the difference in surface ornamentation and distribution of white matter. I prefer the hypothesis that these species occupied the same position in the apparatuses of different species.

The species described by Bryant (1921), here placed in synonomy, all came from the North Evans Limestone of Rickard (1964) and are an indication of the variation of the species. The North Evans Limestone is a lag deposit, and several species of Bryantodus could be present, but the same range of variation is found in the collections from the Genundewa Limestone Member of the Genesee Formation, and this tends to confirm the assignment to a single species.

Bryantodus multidens Ulrich and Bassler was previously accepted by me as a separate species (Huddle, 1968), but a restudy of the Genundewa Limestone Member collections failed to demonstrate any distinguishing characters. Müller and Clark (1967) distinguished the two species on the basis of a strongly arched bar in $B$. multidens, but this distinction is not valid for the types and other specimens of this species in the Rhinestreet Shale Member of the West Falls Formation. I regard the arching in this species as a variable character. 
Occurrence.-In New York, B. colligatus occurs in the North Evans Limestone of Rickard (1964) and in the Genundewa Limestone Member of the Genesee Formation and the Rhinestreet Shale Member of the West Falls Formation. In Ohio, it is found in the Delaware Limestone; in Missouri, in the Grassy Creek Shale (probably Holts Summit Formation or Massie Creek Sandstone of Mehl, 1960); in Tennessee, in the Chattanooga Shale; in Indiana, in the lower New Albany Shale; in Michigan, in the Squaw Bay Limestone; in Utah and Nevada, in the $P$. asymmetricus-Zone, Pilot Shale; in Arizona, in the Martin Formation. In Europe, it occurs in the Rhenish Schiefergebirge, Germany, (where it ranges from the $P$. asymmetricus-Zone to the Palmatolepis triangularis-Zone) and also in Sardinia. In Australia, B. colligatus is found in New South Wales in the Moore Creek Limestone, and in Africa, in the Spanish Sahara.

\section{Bryantodus? commutatus Branson and Mehl}

Bryantodus? commutatus Branson and Mehl, 1934a, p. 223, 224, pl. 16, fig. 15.

Remarks.-Six specimens similar to the form described by Branson and Mehl were found in the West River Shale and Genundewa Limestone Members of the Genesee Formation at Pike Creek (SC-1) and in the Genundewa Limestone Member at Clover Bank quarry (Ed-2) and Beards Creek (Cl-3). It is also similar to the $\mathrm{B}_{2}$ element in Parapolygnathus angusticostatus (Wittekindt) figured by Klapper and Philip (1971, p. 445, fig. 13). These specimens have the same compressed bar and denticles and twisted basal cavity. Other elements of this proposed apparatus are present, except for the platform element.

\section{Bryantodus nitidus Ulrich and Bassler Pl. 20, figs. 5, 6, 8-11}

Bryantodus nitidus Ulrich and Bassler, 1926, p. 24, pl. 4, figs. 11, 12 [See Huddle, 1968, p. 10, for synonomy.]

Remarks.-B. nitidus may represent a growth stage of $B$. retusus, but seems to represent a distinct type of ozarkodinan element, derived perhaps from $B$. retusus. The bar is thinner, the subcusp projection or node is less pronounced, and the denticles are more numerous than in $B$. retusus.

Occurrence.-In New York, in the Genundewa Limestone and West River Shale Members of the Genesee Formation and continues upward into the West Falls Formation, localities $\mathrm{Ba}-3$ and $\mathrm{Py}-7$.
Bryantodus retusus (Bryant)

Pl. 20, figs. 21, 22 ; pl. 21, figs. 3-22; pl. 22, figs. 1-8; pl. 26, figs. 1,2

Prioniodus retusus Bryant, 1921, p. 17, pl. 4, figs. 8, 9, pl. 5, figs. 9,11 , pl. 8, fig. 3 .

Bryantodus retusus (Bryant). Ulrich and Bassler, 1926, p. 21; Holmes, 1928, pl. 7; non Bischoff and Ziegler, 1957, p. 53, pl. 21, fig. 35 (probably Prioniodina sp.).

Prioniodus radiatus Bryant, 1921, p. 16, pl. 4, figs. 10-12, pl. 5, figs. 1-5, 8, pl. 6, fig. 5, pl. 8, figs. $1,2,4,6,8$, pl. 14, fig. 1 (non Prioniodus radiatus Hinde, 1879).

Bryantodus ef. $B$. radiatus (Hinde). Bischoff and Ziegler, 1957 , p. 52, pl. 19, figs. 3a, 3b, 4a, 4b.

Bryantodus radiatus (Hinde). Müller and Clark, 1967, p. 911, pl. 117, fig. 3 .

Bryantodus macrodentus (Bryant). Ulrich and Bassler, 1926, p. 21; Holmes, 1928, p. 7; Bischoff and Ziegler, 1957, p. 49, pl. 21, fig. 17; Mound, 1968, p. 479, pl. 65, figs. 45, 47. Prioniodus muricatus Bryant, 1921, p. 18, pl. 5, fig. 7: Bryantodus muricatus (Bryant). Holmes, 1928, p. 7.

Prioniodus pravus Bryant, 1921, p. 18, pl. 8, fig. 5.

?Prioniodus parvulus Bryant, 1921, p. 20, pl. 9, 8 figs. fragments.

Bryantodus pravus (Bryant). Ulrich and Bassler, 1926, p. 21; Holmes, 1928, p. 7; Freyer, 1961, p. 39; Bischoff and Ziegler, 1957, p. 51, pl. 21, fig. 19, pl. 13, fig. 5, pl. 14, figs. $1,2$.

Bryantodus parvulus (Bryant). Ulrich and Bassler, 1926, p. 21 ; Holmes, 1928, p. 7.

?Bryantodus acutus Branson, 1933, p. 325, pl. 28, fig. 28 .

Bryantodus concavus Huddle. Stauffer, 1938, p. 420, pl. 48, fig. 14.

Bryantodus amalitus Stauffer, 1938, p. 419, pl. 48, figs. 18, 19; Miller and Youngquist, 1947, p. 506, pl. 73, fig. 5.

Bryantodus argutus Stauffer, 1938, p. 419, pl. 48, figs. 16, 20 ; Youngquist, 1945, p. 357, pl. 54, fig. 10; Freyer, 1961, p. 38.

Bryantodus andersonensis Stauffer, 1938, p. 419, pl. 49, fig. 17.

Bryantodus ausablensis Stauffer, 1938, p. 419, pl. 51, fig. 19.

Bryantodus bellatulus Stauffer, 1938, p. 419-420, pl. 48, fig. 23.

Bryantodus bryanti Stauffer, 1938, p. 420, pl. 49, fig. 18.

Bryantodus dignatus Stauffer, 1938, p. 420 , pl. 48, fig. 29 ; Bischoff, 1956, p. 122, pl. 10, figs. 3, 4, 6; Spasov and Stevanovic, 1962, p. 57, pl. 2, fig. 5; Ethington and Furnish, 1962, p. 1265, pl. 173, fig. 18; Mound, 1968, p. 478, pl. 65 , fig. 41 ; Schulze, 1968 , p. $185-186$.

Bryantodus eriensis Stauffer, 1938, p. 421, pl. 48, fig. 11.

Bryantodus grahami Stauffer, 1938, p. 421, pl. 48, figs. 22 , 24, pl. 49 , fig. 8 .

Bryantodus nobilis Stauffer, 1938, p. 422, pl. 49, fig. 14.

Bryantodus olentangiensis Stauffer, 1938, p. 422, pl. 48, figs. $27,28$.

Bryantodus prosseri Stauffer, 1938, p. 422, pl. 49, figs. 1, 4 .

Bryantodus sciotoensis Stauffer, 1938, p. 422, pl. 48, fig. 1; Mound, 1968, p. 479.

Bryantodus stratfordensis Stauffer, 1938, p. 423, pl. 48, fig. 17; pl. 49, fig. 6; Youngquist and Miller, 1948, p. 444, pl. 68, fig. 3; Bischoff and Ziegler, 1957, p. 53, pl. 13, fig. $3 \mathrm{a}, 3 \mathrm{~b}, \mathrm{pl}$. 14, fig. 4 .

Bryantodus cf. B. stratfordensis Stauffer. Bultynck, 1970, p. 93 , pl. 21, fig. 4 . 
Bryantodus wesleyianensis Stauffer, 1938, p. 423, pl. 48, fig. 32.

Bryantodus winchelli Stauffer, 1938, p. 423 , pl. 48, fig. 33; Spasov and Stevanovic, 1962, p. 57, pl. 2, fig. 2.

Bryantodus amanaensis Youngquist, 1945, p. 357, pl. 54, fig. 12.

Bryantodus chesteri Youngquist, 1945, p. 357-358, pl. 55, figs. 12,13 ; Mound, 1968, p. 478, pl. 65, figs. 34, 35 .

Bryantodus inequalis Branson and Mehl. Youngquist, 1945, p. 358, pl. 55, fig. 15.

Bryantodus machaerodus Youngquist, 1947, p. 98, pl. 26, fig. 5.

Bryantodus brachyodontus Miller and Youngquist, 1947, p. 506, pl. 73 , fig. 17.

Bryantodus flabellatus Miller and Youngquist, 1947, p. 506, pl. 73, fig. 23; Youngquist and Miller, 1948, p. 443, pl. 67, fig. 21.

Bryantodus latimarginatus Miller and Youngquist, 1947, p. 506, pl. 72, fig. 13 .

Bryantodus petilus Miller and Youngquist, 1947, p. 507, pl. 72 , figs. $6,7$.

Bryantodus? sp. Miller and Youngquist, 1947, p. 507, pl. 73, figs. 8,19 .

Bryantodus aequalis Youngquist and Miller, 1948, p. 442, pl. 68 , fig. 5 .

Bryantodus bicomis Youngquist and Miller, 1948, p. 442, pl. 67 , figs. 6,7 .

Bryantodus bicristatus Youngquist and Miller, 1948, p. 443, pl. 67, fig. 16; Mound, 1968, p. 477, pl. 65, fig. 38 .

Bryantodus eximus Youngquist and Miller, 1948, p. 443, pl. 67, fig. 15.

Bryantodus masculus Youngquist and Miller, 1948, p. 443, pl. 68, fig. 4; Clark and Ethington, 1967, p. 32, pl. 3, fig. 10.

Bryantodus nitens Youngquist and Miller, 1948, p. 444, pl. 68 , fig. 1.

Bryantodus flexus? Branson and Mehl. Thomas, 1949, pl. 4, fig. 29.

Bryantodus giganteus Branson. Thomas, 1949, pl. 4, fig. 19.

Bryantodus milleri Thomas, 1949, p. 435, pl. 2, fig. 13.

Bryantodus planus? Branson and Mehl. Thomas, 1949, pl. 3 fig. 21, pl. 4, fig. 36 .

Bryantodus sp.? Thomas, 1949, p. 426, pl. 2, fig. 14.

Bryantodus sp. Thomas, 1949, pl. 2, fig. 15.

Bryantodus cf. B. pravus (Bryant). Bischoff and Ziegler, 1957, p. 52, pl. 14, fig. 5, 6; Philip, 1966, p. 153, figs. 15, 18, 19, ?21; Bultynck, 1970, p. 92, pl. 21, fig. 1-3.

Bryantodus alternatus Bischoff and Ziegler, 1957, p. 45, pl. 19 , figs. 40,46

Bryantodus curvatus (Ulrich and Bassler). Müller and Clark, 1967, p. 910, fig. 8.

Lectotype.-Prioniodus retusus Bryant, 1921, Buffalo Soc. Nat. Sci., v. 13, no. 2, pl. 4, fig. 8, USNM 135021. Here designated and refigured (pl. 26, fig. 1).

Diagnosis.-Arched and bowed conodont element with a central cusp, thick bar, and thickened triangular knob or basal expansion below the cusp. Oral edge of bar expanded into small platform on the inside of mature specimens, and on outside in some specimens.
Remarks.-This species is highly variable and grades into Bryantodus colligatus, $B$. typicus, and $B$. nitidus. It is also similar to $B$. scitulus Branson and Mehl. (B. flexus, $B$. mundus, and $B$. planus are regarded as synonoms of $B$. scitulus by Druce 1969, p. 47.) $B$. typicus has a shorter bar and fewer denticles and is generally more massive than $B$. retusus. Bryantodus colligatus (Bryant) has longer bars, more denticles, more prominent inner and outer ledges on the oral edges of bars, and less conspicuous cusp than $B$. retusus or $B$. typicus. $B$. nitidus is smaller, shorter, and thinner than the other species of Bryantodus and may be the young of other species. B. scitulus Branson and Mehl has a rounder bar (not so strongly platformlike) than $B$. retusus, and the denticles on the posterior bar tend to be shorter than those on the anterior bar.

The presence of the basal expansion beneath the cusp is a variable character in several species of Bryantodus. It is absent in many specimens. During development, commonly there are upper and lower ridges on the expansion on some specimens (see pl. 21 , figs. $3,5,7$ ) ; others have a more prominent triangular expansion (pl. 21, figs. 16, 17), which tends to be most fully developed in gerontic specimens.

Early in the development of $B$. retusus (ozarkodinid stage), the oral edge of the bar thickens and expands. This growth is more prominent on the inside, but may be present on the outside as well. The ledges, or incipient platforms, may be smooth or may have nodes of various sizes mainly on the inside. As the platforms widen, the attachment area moves from the sides of the bar to the aboral surface, leaving the ends of the bar last, and the aboral edge of the bar changes from sharp to broad and flat with a small circular pit.

The holotype of $B$. radiatus Hinde is a young specimen that is quite thin, strongly arched, and similar to $B$. planus Huddle (not Branson and Mehl). When I examined the specimen, I concluded that it was not what Bryant called Prioniodus radiatus. This conclusion is also suggested by the figure of the holotype published by Branson and Mehl (1933, pl. 11, fig. 23). This specimen is from the Upper Devonian black shale at Kettle Point, Ontario, Canada. It is younger than the specimens from the North Evans Limestone of Rickard (1964). The other species described by Bryant from the North Evans Limestone, $P$. muricatus, $P$. pravus, and $P$. pravulus, seem to be either gerontic individuals or within the range of variation that $I$ would allow for the species. The name $B$. retusus was selected as the senior synonym because the remain- 
ing cotypes most nearly fit the concept of $B$. radiatus of authors and the typical specimen of the species.

The species of Stauffer, Youngquist, and Miller and Youngquist here assigned to $B$. retusus are mainly early Late Devonian forms, and many occur in the same collection. This is an excellent example of the failure of these authors, and others, including myself, in the 1920's and 1930's to recognize the range of variation of ramiform species.

Occurrence. $-B$. retusus occurs abundantly in the North Evans Limestone of Rickard (1964) and the Genundewa Limestone Member of the Genesee Formation in New York. It also is found in the Squaw Bay Limestone of Michigan; Sweetland Creek Shale, Maple Mill Shale, as used by Anderson (1966), Prospect Hill Sandstone Member of the Hannibal Shale of Moore (1928), and English River Siltstone as used by Anderson (1966) in Iowa; and the Olentangy Shale of Ohio. Mound (1968) figured it from the subsurface of Alberta, Canada, in the Duvernay Formation and Wabamun Group. In Europe, it occurs in the Eifelian and Givetian in the Rhenish Schiefergebirge and in the Frasnian formations in the Rhenish Schiefergebirge, Vogtlandes, Germany, and in western Serbia. Ethington and Furnish (1962) reported it from the Spanish Saraha. Philip (1966) has reported the species from the Middle Devonian Moores Creek Formation in New South Wales, Australia. Probably the species ranges from Eifelian to Famennian. Later forms probably belong to $B$. scitulus.

\section{Bryantodus tortus (Branson and Mehl) \\ Pl. 29, figs. 18, 19; pl. 31, figs. 1-10}

Prioniodella? torta Branson and Mehl, 1934a, p. 216, pl. 16, fig. 1.

Diagnosis.-This flattened bar element is distinguished by the oval compressed denticles which are fused on the posterior bar and separated on the anterior bar, and by the peculiar twist of the bar. The tilt and twist of the aboral surface are also distinctive along with the very small, flat basal cavity.

Description.-Bar thin, twisted like Oulodus, and translucent with nearly vertical central cusp and denticles. Denticles compressed, oval in cross-section, fused together on the posterior bar, and separated on the anterior bar. White matter begins near the top of the bar and extends to tips of cusp and denticles. Transition from clear bar to white matter gradual, not sharp or distinct. Inverted basal cavity on both bars with central aboral groove in base. Basal pit small or absent. Aboral surface near pit below cusp is twisted and tilted toward the inside with the edge of the bar higher on the outside of the groove than on the inside. The aboral surface of this element is quite distinctive. Lateral ridge on the inside of some specimens at the level of the base of the white matter in the denticles.

Occurrence.-Grassy Creek Shale (probably Saverton Shale), Sees Creek, Mo.; Genesee Formation in New York at localities: Py-15, Py-14, Py-7, $\mathrm{Ph}-5, \mathrm{Ph}-1, \mathrm{Nap}-5, \mathrm{Nap}-4, \mathrm{Cd}-7, \mathrm{Cd}-5, \mathrm{Hy}-2$, $\mathrm{Cl}-5, \mathrm{Cl}-4, \mathrm{Cl}-3, \mathrm{Cl}-2, \mathrm{Ba}-2, \mathrm{At}-1, \mathrm{Dp}-3, \mathrm{Dp}-1$, Ed-2, Ed-1, SC-1.

\section{Bryantodus sp. \\ Pl. 20, figs. 1-4}

Remarles.-This small species of Bryantodus has a very strong inner ledge with nodes. It occurs in the Penn Yan Shale Member of the Genesee Formation and the "False Genundewa" or Lodi Limestone of Clarke (in Lincoln, 1895) at Mill Creek (Ov-10).

\section{NOTHOGNATHELLA Branson and Mehl 1934a \\ Nothognathella ziegleri (Clark and Ethington) \\ Pl. 18, figs. 19-31}

Palmatolepis? ziegleri Clark and Ethington, 1967, p. 56-57, pl. 7, figs. 1, 2, pl. 8, figs. 1, 2, 4, 5, 7, 10, 11, 12, 15 .

Nothognathella? ziegleri (Clark and Ethington). Pollock, 1968, p. 433-434, pl. 62, figs. 9-18, 23.

Nothognathella klapperi Uyeno, 1967, p. 5-7, pl. 1; figs. 7 , 8, pl. 2, fig. 1; Szulczewski, 1971, p. 24, pl. 8, figs. 2, 5, 8.

Polygnathus asymmetricus Bischoff and Ziegler. $\mathrm{O}_{1}$ element of multielement species, Klapper and Philip, 1971, p. 449 , fig. 3.

Mesotaxis asymmetrica asymmetrica (Bischoff and Ziegler). $\mathrm{O}_{1}$ element of multielement species, Klapper and Philip 1972, p. 100, pl. 1, fig. 24.

Remarks.-This element is characterized by strong curvature of the carina, unequal development of the plate, and the tendency to have a cusp above the basal cavity and high denticles near the anterior end. The ornamentation of the plates varies from coarse to fine and some specimens are smooth over much of the plate. It seems to be quite variable in amount of curvature and in the strength and inclination of the denticles. The outer platform is higher than the inner, but the variation in the relative sizes of the plates seems to be primarily a matter of growth stage.

The proposed association of $P$. asymmetricus and $N$. klapperi seems to be consistent with the finds of other. workers, but still needs more documentation than that given by Klapper and Philip $(1971,1972)$. The element has been referred to the form genera Nothognathella and Polygnathellus by authors. In New York, it does not occur at most of the localities 
containing $P$. asymmetricus, but it has almost the same range.

Occurrence.-In the North Evans Limestone of Rickard (1964) and the Genundewa Limestone and West River Shale Members of the Genesee Formation at localities Ed-1, Ed-2, Dp-1, Ba-2, Hy-6, $\mathrm{Py}-7, \mathrm{Wg}-1$.

\section{OZARKODINA Branson and Mehl 1933}

Ozarkodina lata Bischoff and Ziegler

Pl. 20, figs. 25-28; pl. 22, figs. 9, 10 ; pl. 26, fig. 5-10 Ozarkodina lata Bischoff and Ziegler, 1957, p. $76-77$, pl. 20 , figs. 9, 16.

Remarks.-This element differs from other ozarkodinan elements in the long flat bar, small basal cavity, and sharp aboral edge of the bar.

Occurrence.-Tully Limestone at Tinker Falls (Tu-2), Gage Gully (Cd-12), and Voorhys Gully (near $\mathrm{Ph}-1$ ).

\section{Ozarkodina macra Branson and Mehl}

Pl. 20, figs. 7, 12-20

Ozarkodina macra Branson and Mehl, 1934a, p. 192, pl. 17, fig. 5 [see Mound (1968, p. 497) for additional synonomy.]

Holotype.-Univ. Missouri C-364-1 from the Grassy Creek Shale (Saverton Shale of Mehl, 1960) at Sees Creek, Mo.

Diagnosis.-This element is characterized by the thin blade curved inward at the posterior tip, small, oval basal pit, slightly flared basal cavity, and deeply inserted denticles, some of which are suppressed.

Remarls.-This type of element has been assigned several specific names including: $O$. immersa (Hinde), O. elegans (Stauffer), 1938, O. congesta Stauffer, 1940, and B. cognatus Huddle, 1934. Many of the ozarkodinan elements have immature stages that look. like this form and, indeed, may not be distinguishable. The young forms of Bryantodus retusus differ in the high posterior bar and lack of incurving and can be distinguished in most collections. Klapper and Philip (1972, pl. 1, figs. 12-19) have placed a similar element in a multielement species referred to Polygnathus.

Occurrence.-Ozarkodinan elements of the macraform type occur in the Moscow Shale, Tully Limestone, and Genesee Formation at the following localities: SC-1, Ed-1, Ed-2, Dp-1, Dp-3, At-1, Ba-2, $\mathrm{Ba}-3, \mathrm{Cl}-2, \mathrm{Cl}-5, \mathrm{Hy}-2, \mathrm{Cd}-7, \mathrm{Cd}-12, \mathrm{Py}-7, \mathrm{Py}-14$, Ov-10.

\author{
NEOPRIONIODONTAN ELEMENTS \\ NEOPRIONIODUS Rhodes and MPiller 1956 \\ Neoprioniodus alatus (Hinde) \\ Pl. 23, figs. 1-9
}

Prioniodus? alatus Hinde, 1879, p. 361 , pl. 16, fig. 5 .

Neoprioniodus alatus (Hinde). Huddle, 1968, p. 25, pl. 6, figs. 1-2 [see for synonomy and description].

Remarles.-This species was described from the North Evans Limestone (of Rickard, 1964) of the Genesee Formation at North Evans, N.Y. It is not possible to associate the element with other members of the multielement apparatus at the type locality because the North Evans Limestone is a lag deposit. The distribution of white matter in the element is similar to several lonchodinan elements such as Prioniodina dialata and also to the ozarkodinan element Bryantodus tortus; these forms may belong to the same apparatus.

Occurrence.-In New York, this species occurs at localities: Tu-2, Dy-10, I-3, I-2, Gen-5, Ov-10, $\mathrm{Wg}-13, \mathrm{Py}-15, \mathrm{Py}-14, \mathrm{Py}-7, \mathrm{Ph}-7, \mathrm{Ph}-1, \mathrm{Cd}-12$, $\mathrm{Nap}-5$, Nap-4, Cd-7, Cd-5, Cl-4, Cl-3, Ba-3, Ba-2, At-1, Dp-3, Dp-1, Ed-2, Ed-1, SC-1. It ranges from the Tully Limestone to the West Falls Formation.

Neoprioniodus armatus (Hinde) Pl. 23, figs. 10-17

Prioniodus armatus Hinde, 1879, p. 360-361, pl. 15, figs. $20,21$.

Neoprioniodus armatus (Hinde). Huddle, 1968, p. 25-26, p. 6, fig. 11 ; p. 7, figs. 1 , 4; Orr, 1971, p. 43-44, pl. 3, fig. 8 [see for synonomy].

Remarles.-Differs from $N$. alatus in the narrower bar and wide spacing of denticles. White matter diffuse, grading into clear bar matter.

Occurrence.-In New York in the Genesee, Sonyea, and West Falls Formations at localities: I-3, Py-15, Py-14, Py-7, Ph-1, Nap-4, Cd-7, $\mathrm{Hy}-2, \mathrm{Cl}-4$, Cl-3, Cl-2, Ba-3, At-1, Dp-3, Dp-1, Ed-2, Ed-1, SC-1.

\section{ENANTIOGNATHUS Mosher and Clark 1965}

Type species.-Apatognathus inversus Sannemann 1955.

Geologic range.-Devonian to Triassic.

$$
\begin{aligned}
& \text { Enantiognathus lipperti (Bischoff) } 1956 \\
& \text { Pl. 26, figs. 15-20; pl. 27, figs. 3, } 4
\end{aligned}
$$

Apatognathus lipperti Bischoff, 1956, p. 121-122, pl. 9, figs. 27, 31; Bischoff and Ziegler, 1956, p. 145, pl. 14, figs. 1, 2; Lys and Serre, in Lys, Serre, and Deroo, 1957, p. 1040, pl. 1, fig. 4; Scott and Collinson, 1961, p. 122, pl. 2, fig. 10; Ethington and Furnish, 1962, p. 1264, pl. 173, fig. 16; Helms, 1959, p. 663, pl. 1, fig. 16. 
Gnamptognathus lipperti (Bischoff). Lindström, 1964, p. 153-155, 177; Glenister and Klapper, 1966, p. 803-804, pl. 96, fig. 13; Wolska, 1967, p. 377, pl. 1, fig. 7; Clark and Ethington, 1967, p. 34, pl. 2, fig. 2.

Enantiognathus lipperti (Bischoff). Mound, 1968, p. 481, pl. 65 , figs. $30,46,51-54$.

Remarks.-This species may have one to three large denticles at the sharp bend, but the one at the bend is called the cusp. Some specimens from the Genesee Formation in New York, like those from Australia figured by Glenister and Klapper (1966), have a third bar extending from the inside of the posterior bar. Gnamptognathus walliseri has the third bar on the anterior bar. These forms probably served a similar function in the conodont apparatus.

Occurrence.-In New York, E. lipperti occurs in the Genesee Formation at localities: $\mathrm{Py}-7, \mathrm{Ph}-7$, $\mathrm{Ph}-1$, Nap-4, Cd-7, Cl-4, Cl-5, Cl-3, Cl-2, Dp-3, Dp-1, Ed-1, SC-1.

\section{Enantiognathus? guntharii (Ziegler)}

Pl. 26, figs. 11-14; pl. 27, figs. 1, 2

Falcodus guntharii Ziegler, 1958, p. 52-53, pl. 12, figs. 4-7; Bartenstein and Bischoff, 1962, p. 54, pl. 5, fig. 18.

Remarks.-This element is difficult to place in a form genus. It is not flat enough to be referred to Falcodus, and the twist of the anticusp does not agree with the form genus Ligonodina, nor with Enantiognathus. The strong bowing and the anticusp suggest that the element belongs in this group of neoprioniodontan elements, but perhaps it is a hindeodellan element.

Occurrence.-About 20 specimens from Genesee Formation in New York at localities: $\mathrm{Py}-7, \mathrm{Ph}-7$, Nap-4, At-1, Dp-3, Dp-1. Ziegler (1958) reported this species from the Cephalopodenkalke in Germany.

Synprioniodina
synonomy).

The synprioniodinan element of the conodont apparatus replaces the neoprioniodontan element in some apparatuses. Two general types of synprioniodinan element occur in the Genesee rocks of New York, and these are referred to the form species $S$. alternata and $S$. prona. Both species vary greatly, and they seem to intergrade. Some specimens might be referred to $S$. regularis Branson and others to $S$. deflecta Ulrich and Bassler. It would be possible to split this element into a number of units on the basis of the angle of the cusp, insertion of denticles, alternations of denticles, curvature of the bar, and so forth, but there would be only a few specimens of each unit. Until we know more about the composition of the conodont apparatuses present in the Genesee, further subdivision of the neoprioniodontan elements is not needed. Undoubtedly several conodont apparatuses are represented in the Genesee Formation, and each probably had a neoprioniodontan element. I have recognized only four, but probably more are present. Intensive study of these apparently nondiagnostic elements is not worthwhile at present.

Synprioniodina alternata Bassler 1925

Pl. 19, figs. 26-30; pl. 23, figs. 18,19

Syprioniodina alternata Bassler, 1925, Huddle, 1968 [see for synonomy].

Holotype.-USNM 11308 from the Gassaway Member of the Chattanooga Shale, New Market, Ala.

Remarks.-I have distinguished the element $S$. alternata from $S$. prona primarily on the thickness of the bar and the insertion of the denticles. S. alternata has a thin bar with a narrow base and a narrow basal groove. The denticles generally alternate in size, and the white matter extends deep into the bar. The angle of cusp and posterior bar ranges from about $120^{\circ}$ to $160^{\circ}$. The anticusp curves outward strongly, and the base is expanded on the inside. Small specimens, which I have considered immature S. alternata in spite of lacking a complete growth series, have a cusp angle of about $160^{\circ}$ and a very small expansion. These may represent an early form of $S$. regularis Branson and represent the neoprioniodontan element of another species.

Occurrence.-In New York in the Genesee Formation at localities: $\mathrm{Py}-15, \mathrm{Py}-14, \mathrm{Py}-7, \mathrm{Ph}-1, \mathrm{Nap}-4$, $\mathrm{Cd}-5$, $\mathrm{Hy}-2, \mathrm{Cl}-4, \mathrm{Cl}-5, \mathrm{Cl}-3, \mathrm{Cl}-2, \mathrm{Ba}-3, \mathrm{Ba}-2$, At-1, Dp-3, Dp-1, Ed-2, Ed-1, SC-1.

\section{Synprioniodina prona Huddle Pl. 19, figs. 31-36}

Synprioniodina prona Huddle, 1934 [see Orr, 1971, S. regularis for synonomy].

Remarks-Orr (1971) placed this species in synonomy with $S$. regularis, but as discussed previously I have chosen to retain both $S$. alternata, which I regard as the probable senior synonym of $S$. regularis, and $S$. prona. If all these forms were placed in a single-element species, the name should be $S$. alternata. I suspect, in spite of the wide variation all workers have reported, that as we recognize conodont apparatuses, we will find that several of these conservative neoprioniodontan elements did belong to separate apparatuses. It will be difficult, and maybe impossible, to distinguish the apparatus species on the basis of this element. 
I place in $S$. prona, neoprioniodontan elements with an arched bar that is thick, triangular in cross section with a shoulder on the inner upper side of the bar, a strong groove in the base of the bar, and a large expansion at the base of the cusp which forms the inside lip of the basal pit.

Several specimens have a small basal plate attached to the basal cavity and the attachment area along the side of the bar. The presence of the base was indicated by the attachment area, but this is one of the few reports of its preservation.

Occurrence.-S. prona ranges from Moscow Shale to West Falls Formation in western New York at localities: Gen-2, Ov-10, Ov-12, Py-7, Ph-1, Nap-5, $\mathrm{Nap}-4, \mathrm{Cd}-7, \mathrm{Cd}-5$, Cl-4, Cl-5, Cl-3, Cl-2, Ba-3, Ba-2, At-1, Dp-3, Dp-1, Ed-2, Ed-1, SC-1.

\section{HINDEODELLAN ELEMENTS} ANGULODUS Huddle 1934

Angulodus Huddle, 1934, p. 76; Hass, 1962, p. W55; Lindström, 1964, p. 151; Mound, 1968, p. 472; Bultynck, 1970 , p. 90.

Cervicornoides Stauffer, 1938, pl. 424.

Type-species.-Angulodus demissus Huddle, 1934.

Angulodus demissus Huddle 1934

Pl. 25, figs. 10, 11, 14, 16-20; pl. 26, fig. 4

Angulodus demissus Huddle, 1934, p. 77, pl. 10, fig. 15; Branson and Mehl, in Shimer and Shrock, 1944, p. 240, pl. 93, fig. 58; Bischoff and Ziegler, 1957, p. 43, pl. 8, fig. 9, pl. 20, fig. 1; Müller and Clark, 1967, p. 910, pl. 118, fig. 11 ; Bultynck, 1970 , p. 89 , pl. 20, fig. 1, 3 .

Holotype.-Indiana University Paleontological Colln. 2341, New Albany Shale, Indiana.

Diagnosis.-This species is characterized by its short posterior bar, rounded denticles and cusp, and rounded bar with a shoulder on the inside. Young specimens have a thinner bar, but they can be recognized by the apparent offset of the cusp on the inside of the unit. This apparent offset is due to the greater thickness of the cusp, about double the thickness of the denticles. The basal cavity is asymmetrically elongated similar to that in Plectospathodus (pl. 25, fig. 17).

Remarlss.-A. pergracilis and A. walrathi have compressed bars, and their anterior bars are longer than in A. demissus. A. walrathi has fine denticles, a small cusp, and the flattened bar is not bowed inward; in oral view, the bar is nearly straight. A. pergracilis has compressed cusp and denticles and a flat or hollow area on the inside of the cusp. The anterior bar is strongly bowed inward.

Occurrence.-Moscow Shale to West Falls Formation in New York at localities: Ov-12, Py-15, Ph-7, $\mathrm{Ph}-5, \mathrm{Ph}-1$, Nap-5, Nap-4, Cd-7, Cd-5, Cl-5, Cl-4,
Cl-3, Cl-2, Ba-3, Ba-2, At-1, Dp-3, Dp-1, Ed-2, Ed-1, SC-1.

\section{HINDEODELLA Bassler 1925}

Hindeodella Bassler, 1925, p. 219; Ulrich and Bassler, 1926, p. 38-39; Hass, 1962, p. W46; Lindström, 1964, p. 151; Huddle, 1968, p. 15; Jeppsson, 1969, p. 13.

Hindeodina Hass, 1959.

Type species._Hindeodella subtilis Bassler 1925.

Remarles.-From what is known about "assemblages" in the Mississippian and Pennsylvanian, it seems probable that the hindeodellan elements formed a fundamental part of the conodont apparatus and may be the most abundant elements. They also seem to have been conservative and, consequently, have not been very useful in conodont zonation. Little is known of their range of variation because few collections contain abundant whole specimens that might have come from a single biologic species. "Assemblages" have not been studied for range of variation of their elements. Probably other elongate bars such as Plectospathodus and Ligonodina served the same function in the conodont apparatus.

Geologic range.-Middle Ordovician to Triassic.

\section{Hindeodella alternata Ulrich and Bassler 1926}

Pl. 24, figs. 6, 7, 12, 13, 18, 19

Hindeodella alternata Ulrich and Bassler, 1926, p. 40, pl. 1, figs. 14-15; Cooper and Sloss, 1943, pl. 29, fig. 18; Müller and Clark, 1967, p. 913, pl. 118, figs. 2-3; Huddle, 1968, p. 15 , pl. 5 , figs. 1,3 .

Hindeodella cf. $H$. alternata Ulrich and Bassler. Durdanović, 1968, p. 98 , pl. 1 , fig. 7 .

Hindeodella germana Holmes. Durdanović, 1968, p. 98, pl. 1, fig. 8.

Lectotype.-Ulrich and Bassler, 1926, pl. 1, fig. 14, USNM $11300 \mathrm{VP}$, refigured by Huddle, 1968, pl. 5, fig. 1. Rhinestreet Shale Member, West Falls Formation, Shaleton (now Weyer), N.Y.

Diagnosis.-The heavy bar, alternating denticles increasing in size toward the posterior deflection, and the downward anterior deflection characterize this species. A small basal pit is present below the cusp in some specimens.

Remarks.-This species differs from Hindeodella angulus in the small size of the basal pit and the lack of an enlarged or swollen margin of the pit below the cusp. The anterior deflection is less like an anticusp than in $H$. angulus.

Geologic occurrence.-Genesee to West Falls Formations in New York at localities: Py-7, Nap-4, $\mathrm{Cd}-7, \mathrm{Cd}-5, \mathrm{Hy}-2, \mathrm{Cl}-4, \mathrm{Cl}-2, \mathrm{Ba}-2, \mathrm{Ed}-2, \mathrm{Ed}-1$, SC-1. It also occurs in the upper 3 feet of the Squaw Bay Limestone, Partridge Point, Alpena County; 
Mich., and in the Lower Devonian Emsian of Ljubljana River, Yugoslavia.

Hindeodella angulus Huddle

Pl. 24, fig. 1-5; 8-11, 14, 15; pl. 25, figs. $12,13,15$

Hindeodella angulus Huddle, 1934, p. 44, pl. 5, fig. 14. [Note: the numbers on figs. 14 and 16, pl. 5 , Huddle, 1934, are reversed].

Holotype.-Indiana University, Colln. 2315, lower New Albany Shale, Prather, Ind.

Diagnosis.-The anterior process is sharp edged with lateral attachment areas and is sharply deflected downward. The basal pit is larger than in other species of Hindeodella and has a distinct lateral lip. Near the cusp, the base of the bar is flat with a midline groove, but it is sharp edged basally toward the anterior and posterior ends. There is a strong posterior projection.

Remarks.-This species is intermediate between Hindeodella and Ligonodina. It is similar to Ligonodina in the presence of the strongly deflected anterior process and the distinct basal cavity, but there is no true anticusp and the anterior process is sharp edged aborally, rather than flat with a midline groove as in Ligonodina. The anticusp in Ligonodina is also twisted more strongly inwardly.

$H$. angulus is difficult to distinguish from $H$. alternata, and it may be a junior synonym. It differs in the larger basal pit and the larger more strongly deflected anterior process. The type is a large, probably gerontic, specimen, but smaller specimens also have the large strongly deflected anterior process and large basal pit. Typically, $H$. alternata has no basal pit or, if present, it is a very small one. See Ligonondina acuta for comparison with that species.

Occurrence.-In New York in the Genesee Formation, it occurs at localities: Py-15, Py-14, Py-7, Nap-4, Cd-7, Cl-5, Cl-4, Cl-3, Cl-2, Ba-5, Ba-3, At-1, Dp-3, Dp-1, Ed-2, Ed-1, SC-1.

\section{Hindeodella compressa Huddle Pl. 25, figs. 5, 6}

Hindeodella compressa Huddle, 1934, p. 41, pl. 5, fig. 4; Cooper and Sloss, 1943, pl. 28, figs. 25; Druce, 1969, p. 68 , pl. 9 , figs. 8, 9 .

Hindeodella sp. Huddle, 1934, p. 41, pl. 5, fig. 1.

Holotype.-Indiana University Paleonitological Colln. 1858, Upper New Albany Shale, New Albany, Ind.

Diagnosis.-A species of Hindeodella with a thin, flat, slightly bowed bar, fine denticles, a small cusp, and an incurved short anterior process.
Occurrence.-Upper part of New Albany Shale, Indiana, Mississippian shale in Alberta, and lower Carboniferous, Burt Range Formation, Bonaparte Gulf basin, northern Australia. In New York in the Genesee Formation at localities: $\mathrm{Cd}-7, \mathrm{Cl}-4, \mathrm{Cl}-\mathbf{5}$, Ed-1.

\section{Hindeodella elongata Huddle \\ Pl. 25, figs. 3, 4, 7-9}

Hindeodella elongata Huddle, 1934, p. 42, pl. 5, figs. 5, 6; Cooper, 1939, p. 389, pl. 46, fig. 26; Cooper and Sloss, 1943, pl. 28, figs. 18, 19, 21, 36; Scott and Collinson, 1961, p. 125 , pl. 2, fig. 15 .

Hindeodella ampla Cooper. Cooper and Sloss, 1943, p. 173, pl. 28, fig. 30.

Holotype.-Indiana University Colln. 1848, upper New Albany Shale, New Albany, Ind.

Diagnosis.-A species of Hindeodella with thin bar, a very long anterior process, a small cusp, and very fine denticles.

Remarks.-This species is common in Upper Devonian black shale as isolated specimens. It differs from Angulodus walrathi in the long, nearly straight, anterior process and the lack of a posterior process. The denticles are smaller toward the posterior end.

Occurrence.-Upper part of New Albany Shale, Indiana; shale below Welden Limestone, Ada, Okla.; Mississippian shale, Montana, and Alberta, Canada. In New York, the Genesee Formation at localities: Py-7, Nap-4, Cd-7, Cl-5, Cl-4, Cl-2, Ba-3, Dp-3, Ed-2, Ed-1, SC-1.

\section{Hindeodella subtilis Bassler \\ P1. 25, figs. 1, 2}

Hindeodella subtilis Bassler, 1925, p. 219; Ulrich and Bassler, 1926, p. 39, pl. 8, figs. 17-19, text fig. 3, no. 4; Ethington, 1965, p. 572-573; Müller and Clark, 1967, p. 913-914, pl. 118; Huddle, 1968, fig. 1 ; pl. $16-19$, pl. 5, figs. 5, 7, 8 , 10-15; Rhodes, Austin, and Druce, 1969, p. 125-126, pl. 29, figs. $6 \mathrm{a}-7 \mathrm{~b}, 9-10 \mathrm{~b}$; Druce, 1969 , p. 69 , pl. 10, figs. 3, 4; Seddon, 1969, p. 25; see Huddle (1968) and Rhodes, Austin, and Druce (1969) for additional synonomy.

Lectotype.-USNM 10985 VP, Gassaway Member, Chattanooga Shale, Quicks Mill, Ala.

Diagnosis. $-H$. subtilis has a strongly incurved anterior process, a large flattened cusp, a small basal cavity, a long thin posterior bar with numerous alternating denticles that decrease in size posteriorly.

Remarks.-This species is quite variable, and many of the varieties have been named. Many of these are probably synonyms, as indicated, but some may be distant and belong in separate multielement apparatus species. At present, this taxon has little 
biostratigraphic significance, and the other elements of the conodont apparatus are not known.

Occurrence.-In New York, $H$. subtilis occurs in the Genesee Formation at localities: $\mathrm{Py}-7, \mathrm{Ph}-5$, $\mathrm{Ph}-1, \mathrm{Cd}-12, \mathrm{Cd}-7$, Nap-4, $\mathrm{Hy}-2, \mathrm{Cl}-5, \mathrm{Cl}-4, \mathrm{Cl}-3$, Cl-2, Dp-3, Dp-1, Ed-2, Ed-1, SC-1.

\section{DIPLODODELLA Bassler 1925}

Diplododella Bassler, 1925, p. 219; Ulrich and Bassler, 1926, p. 41; Hass, 1962, p. W50; Huddle, 1968, p. 11, 12; Olivieri, 1969, p. 11, 12.

Type-species._Diplododella bilateralis Bassler, 1925.

Remarks.-Ellsonella is not a synonym of $D i$ plododella, as indicated by Huddle (1968, p. 11). Ellsonella differs from Diplododella in its granular surface texture and is a synonym of Dinodus Cooper, 1939.

Diplododella confertissima (Ulrich and Bassler) 1926

Hibbardella? confertissima Ulrich and Bassler, 1926, p. 38, pl. 3, fig. 5 .

Diplododella confertissima (Ulrich and Bassler). Huddle, 1968, p. 12, pl. 7, fig. 5 .

Remarks.-Most collections lack abundant specimens of delicate forms, such as this species. Possibly $D$. aurita (Sannemann) 1955, pl. 5, fig. 11, is a junior synonym.

Occurrence.-In New York, this species occurs in the Genesee Formation at localities: Wg-13, Py-14, Py-15, Py-7, Ph-7, Nap-4, Cd-7, Cl-5, $\mathrm{Cl}-4, \mathrm{Cl}-3, \mathrm{Cl}-2, \mathrm{Ba}-3, \mathrm{At}-1, \mathrm{Dp}-3, \mathrm{Dp}-1$.

HIBBARDELLA Bassler 1925

Hibbardella Bassler, 1925, p. 219; Ulrich and Bassler, 1926, p. 37; Branson and Mehl, 1941a, p. 175-176; Müller, 1956, p. 825; Hass, 1962, p. W50; Bergström, 1964, p. 24; Müller and Clark, 1967, p. 912-913; Mound, 1968, p. 482-483; Huddle, 1968, p. 12-13; Rhodes, Austin, and Druce, 1969 , p. $110-111$.

Type species.-Prioniodus angulatus Hinde 1879. "Genesee Shale" (probably Rhinestreet Shale, West Falls Formation), North Evans, N.Y.

Remarks.-Several generic names have been proposed for conodont elements that have a symmetrical anterior arch and a posterior bar. Huddle (1968) recognized three genera, and Rhodes, Austin, and Druce (1969) proposed three subgenera of $\mathrm{Hib}$ bardella on the basis of the shape of the cusp and the character of the basal cavity. Probably this element type occurred in a similar position in the conodont apparatus of different species and perhaps genera. The associations of the hibbardellan elements are unknown, and a revision of these form genera requires larger collections than I have from New York. Probably, the thin flattened forms with tiny basal cavities, here assigned to Diplododella, were associated with thin flattened forms of hindeodellan elements. Typical hibbardellan elements probably were associated with thick heavy-barred hindeodellan and lonchodinan elements.

Hibbardella angulata (Hinde)

Prioniodus angulatus Hinde, 1879, p. 360, pl. 15, fig. 17.

Hibbardella angulata (Hinde). Ulrich and Bassler, 1926, p. 37 , pl. 3, figs. 2-3; Huddle, 1968 , p. 14 , pl. 8 , figs. 2 , 7 , pl. 9, fig. 3 (see for additional synonomy).

Holotype.-British Museum of Natural History A-4180.

Diagnosis.-This species is characterized by a rounded slender cusp which is grooved posteriorly, small basal cavity, and discrete denticles.

Remarks.-I think that the type specimen BMNH A-4180 has a rounded cusp with a groove in the back. My notes on the type species made in October 1967, indicate the groove, but not the shape of the cusp. The subgenus (Hibbardella) was described by Rhodes, Austin, and Druce (1969, p. 110-111) as having a cusp with a sharp lateral edge, and oval cross-section. I doubt if the type specimen fits this description. In any case, the specimens from the Genesee Formation of New York that are here referred to $H$. angulata do not have a sharp-edged cusp.

Occurrence.-In New York in the Genesee Formation at localities: I-3, $\mathrm{Py}-15, \mathrm{Py}-14, \mathrm{Py}-7, \mathrm{Ph}-7$, $\mathrm{Ph}-1$, Nap-4, Cd-7, Cd-5, Cl-5, Cl-4, Cl-3, Cl-2, At-1, Dp-3, Dp-1, Ed-2, Ed-1.

Hibbardella subequalis Ulrich and Bassler

Hibbardella subequalis Ulrich and Bassler, 1926, p. 38, pl. 3, figs. 6, 7; Huddle, 1968, p. 15-16, pl. 6, figs. 6, 8, pl. 8, figs. $3,8,9$, pl. 9 , fig. 2 .

Lectotype.-USNM 11296 VP, Rhinestreet Shale Member West Falls Formation, Weyer, N.Y.

Remarks.-The species differs from $H$. angulata in the flat cusp, without a posterior groove and the triangular bar.

Occurrence.-In New York in the Genesee Formation at localities: $\mathrm{Py}-7, \mathrm{Ph}-7, \mathrm{Cd}-12, \mathrm{Cd}-7$, Nap-4, Cl-4, Cl-2, Dp-3, Dp-1, Ed-2, Ed-1.

Hibbardella sp.

Remarks.-Broken specimens probably referable to Hibbardella are found in many collections. They are not well enough preserved nor abundant enough to determine the species.

\section{TRICHONODELLA Branson and Mehl 1948 \\ Trichonodella blanda (Stauffer) \\ Pl. 29, figs. 13-17; pl. 30, fig. 9}

Trichognathus blanda Stauffer, 1940, p. 434, pl. 59, figs. 61,70 
Trichonodella blanda (Stauffer). Bischoff and Ziegler, 1957, p. 120 , pl. 12 , figs. $7 \mathrm{a}, \mathrm{b}$; pl. 20, figs. 4, 20; Ethington and Furnish, 1962, p. 1287.

Trichonodella cf. blanda (Stauffer). Bischoff and Ziegler, 1957, p. 120, pl. 20, figs. 8a, b.

non Trichonodella blanda (Stauffer). Mound, 1968, p. 516, pl. 70, fig. 9, pl. 71, fig. 8 .

Prioniodus recedens Bryant, 1921, pl. 2, fig. 2 (USNM 135010).

Diagnosis.-Strongly arched, slightly bowed, nearly symmetrical element, with discrete cusp and denticles. White matter diffuse and continuing into the upper half of the bar in large specimens. Base of bar flat, grooves extending from the large basal cavity. Bar extremities flattened with lateral attachment scars. Posterior bar represented by an enlargement of the base of the cusp.

Remarks.-The dark color of the bar, the distribution of the white matter in the bar, and the heavy bar with a flat base suggest that this element may be part of a conodont apparatus including the forms species, Prioniodina dialata, Bryantodus? aversus, $B$. tortus, Lonchodina subsymmetrica, and perhaps Ligonodina panderi.

Occurrence.-In New York, the element occurs in the Genesee Formation at localities: Dy-10, I-3, $\mathrm{Py}-15, \mathrm{Py}-14, \mathrm{Py}-7, \mathrm{Nap}-4, \mathrm{Cd}-7, \mathrm{Cl}-5, \mathrm{Cl}-4, \mathrm{Cl}-3$, Cl-2, Ba-3, At-1, Dp-3, Dp-1, Ed-2, SC-1.

\section{LIGONODINAN ELEMENTS LIGONODINA Bassler 1925}

Ligonodina Bassler, 1925, p. 218; Ulrich and Bassler, 1926, p. 12-13; Hass, 1962, p. W50; Lindström, 1964, p. 150; Huddle, 1968, p. 18.

Hamulosodina Cooper, 1931, p. 239.

Idioprioniodus Gunnell, 1933, p. 265.

Neocordylodus Cooper, 1939, p. 396.

Type species.-Ligonodina pectinata Bassler, 1925.

\section{Ligonodina acuta Branson and Mehl 1934a} Pl. 27, figs. 16-21

Ligonodina acuta Branson and Mehl, 1934a, p. 200, pl. 15, figs. 32, 27; Clark and Ethington, 1967, p. 40-41, pl. 3, fig. 5 .

Ligonodina ef. L. acuta Youngquist, 1947, p. 103, pl. 24, figs. $13,19$.

Holotype.-University of Missouri Cat. No. 367-4, Grassy Creek Shale (probably Saverton Shale) Sees Creek, Monroe County, Mo.

Diagnosis.-A hindeodellanlike species of Ligonodina with the anticusp not offset and with distal ends of the posterior bar and anticusp thin and sharpedged aborally. Basal cavity large and extending a short distance into the posterior bar and anticusp, but inverted distally. Denticles alternate in size.
Remarlss.-This species is similar to Hindeodella angulata Huddle and may indeed be an extreme variation of that species. If so, the older name acuta should be used for the species. L. acuta has a larger basal cavity, and the bar is flattened aborally near the cusp. L. spicatus has a more gently curving anticusp that is not as strongly deflected downward as L. acuta. Intermediate specimens occur between the three species; possibly, they all belong in the same apparatus, but until more is known about multielement species, I prefer to leave them separate.

Occurrence.-In New York in the Genesee Formation at localities: Dp-3, Dp-1, Ed-2, Ed-1.

\section{Ligonodina magnidens Ulrich and Bassler 1926}

Ligonodina magnidens Ulrich and Bassler, 1926, p. 12, pl. 2, figs. 5, 6; Huddle, 1968, p. 18-19, pl. 9, fig. 8, pl. 10, figs. 9, 12, 14-16, pl. 11, figs. 1-4.

Lectotype.-USNM $11248 \mathrm{VP}$.

Remarks.-See Huddle (1968) for description and illustrations. This species is rare in the Genesee Formation and was found only in the West River Shale Member at Linden (Ba-2).

$$
\begin{gathered}
\text { Ligonodina panderi (Hinde) } 1879 \\
\text { Pl. 27, figs. } 7-15
\end{gathered}
$$

Prioniodus panderi Hinde, 1879, p. 361, pl. 16, fig. 4.

Ligonodina panderi Ulrich and Bassler, 1926, p. 13, pl. 2, figs. 1, 2; Huddle, 1968, p. 19, pl. 9, fig. 11, pl. 10, figs. $1-8,11$ [see for additional references].

Type.-Probably lost. Not in the catalog at British Museum of Natural History.

Remarlss. - The white matter in the denticles is more pronounced in mature specimens than in the immature specimens. Cusp and denticles do not appear to be inserted in the bar. The boundary between white matter and clear matter is indistinct and cloudy. It is at or near the junction of the cusp or denticle and the bar.

Occurrence.-In New York in the Tully Limestone and Genesee Formation at localities: Tu-2, Dy-10, I-3, I-2, Gen-5, Gen-4, Ov-12, Wg-13, Py-15, $\mathrm{Py}-14, \mathrm{Py}-7, \mathrm{Ph}-7, \mathrm{Ph}-5, \mathrm{Ph}-1, \mathrm{Nap}-5$, Nap-4, $\mathrm{Cd}-12, \mathrm{Cd}-7, \mathrm{Cd}-5, \mathrm{Hy}-2, \mathrm{Cl}-5, \mathrm{Cl}-4, \mathrm{Cl}-3, \mathrm{Cl}-2$, Ba-3, Ba-2, At-1, Dp-3, Dp-1, Ed-2, Ed-1, SC-1.

$$
\begin{gathered}
\text { Ligonodina spicata (Hinde) } \\
\text { Pl. 28, figs. 1-11 }
\end{gathered}
$$

Prioniodus spicatus Hinde, 1879, p. 361, pl. 16, figs. 1-3 [not Bryant, 1921, p. 19, pl. 6, fig. 4].

Ligonodina spicata (Hinde). Branson and Mehl, 1933, p. 138 , pl. 11, figs. $25,27$.

Ligonodina flexuosa Branson and Mehl, 1934a, p. 199, pl. 15, fig. 26 ; Cooper, 1939 , p. 390-391, pl. 45, fig. 46; Thomas, 1949, pl. 3, fig. 14; Mound, 1968, p. 490, pl. 66, figs. 21, 29 [see for additional synonomy]. 
Lectotype.-Here designated. British Museum of Natural History Cat. No. A 4176, the specimen figured by Hinde (1879, pl. 16, fig. 3) from "Genesee Shale," (probably Rhinestreet Shale, West Falls Formation) North Evans, N.Y.

Diagnosis.-A species of Ligonodina with a long thin posterior bar, base nearly straight horizontally but may wave laterally. Denticles not apparently inserted, white-matter boundary indistinct or cloudy near the base of the denticle or cusp. Five or six denticles on the anticusp. Large thin-walled basal cavity and trough along the base of the posterior bar. Angle of anticusp to bar variable. Cusp flattened and twisted.

Remarks.-Distinguished from other species by the size alternation of denticles and the large thinwalled basal cavity, which is relatively smaller in the largest specimens. The trough along the base of the posterior bar is partially filled in large specimens.

Occurrence.-In New York in the Genesee Formation at localities: Py-7, Nap-4, Cl-5, Cl-4, Cl-2, At-1 ?, Ed-1, SC-1.

\section{LONCHODINAN ELEMENTS LONCHODINA Bassler 1925 \\ Lonchodina clavata (Hinde) \\ Pl. 30, figs. 12-17}

Prioniodus clavatus Hinde, 1879, p. 360, pl. 15, fig. 16.

Lonchodina arcuata Ulrich and Bassler, 1926, p. 32, pl. 5, fig. 15; Huddle, 1968, p. 21-22, pl. 11, figs. 5-13.

Holotype.-BNHM A-4186 from the "Conodont Bed" at North Evans, N.Y. (Examined Oct. 2, 1967).

Diagnosis.-This element is characterized by a bowed, arched, and twisted bar so that the denticles point inward on one side of the cusp and outward on the other. The inside of the bar, as indicated by the curvature of the cusp, is the convex side of the element; the outside is concave. Bar material dark amber colored; white matter is diffuse. The base of the bar is flat, nearly to the extremities of the bars and a large basal cavity and grooves extend under the bars. In some specimens, the bar is offset near the cusp by the twist.

Occurrence.-In the Genesee Formation of New York at localities: Gen-2, $\mathrm{Py}-7, \mathrm{Ph}-5, \mathrm{Nap}-4, \mathrm{Cd}-7$, Cl-5, Cl-4, Cl-3, Cl-2, Ba-3, Ba-2, At-1, Dp-3, Dp-1, Ed-2, Ed-1.

Lonchodina perlonga Ulrich and Bassler

Lonchodina perlonga Ulrich and Bassler, 1926, p. 22, pl. 5, figs. 6,7 ; Huddle, 1968, p. 22-23, pl. 12, figs. 1-3.
Remarks.-This element was described by Huddle (1968). The bar is heavy, and the white matter is confined to denticles at the top of the bar. The contact between clear dark material and white matter is diffuse, and the denticles do not seem to be inserted. The base of the bar is flat near the cusp and tapers toward the ends with lateral attachment areas.

Occurrence.-In the Genesee Formation in New York at localities: Py-15, Py-7, Cd-12, Nap-4, Cl-5, Cl-2, Dp-3, Ed-1, SC-1.

\section{Lonchodina richteri Bischoff and Ziegler Pl. 31, figs. 11-13}

Lonchodina richteri Bischoff and Ziegler, 1957, p. 70-71, pl. 10, figs. 4a, b, 5a, b, 15a, b.

Lonchodina ramulata :Bischoff and Ziegler, 1957, p. 69-70, pl. 10, figs. 1a, b, $2,3$.

Remarks.-Lonchodinan element more or less arched and bowed; it has a prominent shallow basal cavity and a strong inward projection. The bowing is reversed from normal with the inside convex and the outside concave (assuming the cusp is inclined inward). Commonly, there is a large denticle near the end of the short posterior bar. Cusp and denticles oval in cross section in young specimens, and the white matter contrasts sharply with the clear bar material. Germ denticles and small denticles are present between the larger denticles on some specimens. Bars thin with attachment scars toward the extremities, and the tips may recurve.

Occurrence.-In the Genesee Formation of New York at localities: $\mathrm{Py}-7, \mathrm{Ph}-5, \mathrm{Nap}-4, \mathrm{Cd}-7, \mathrm{Cd}-5$, Cl-4, At-1, Ed-1, SC-1.

\section{Lonchodina subsymmetrica Ulrich and Bassler \\ Pl. 29, figs. 10-12; pl. 31, figs. 22-24}

Lonchodina subsymmetrica Ulrich and Bassler, 1926, p. 34, pl. 1, fig. 24, pl. 5, fig. 8, pl. 6, figs. 6-7; Huddle, 1968, p. 23 , pl. 12, figs. $3-14$.

Remarks.-See Huddle (1968) for description. The key characters are the strong bowing of the bar and the boss at the base of the cusp. The large basal cavity extends under the bars and the flat base. Some specimens are similar to Bryantodus retusus and others to Bryantodus biculminatus, but the element is distinguished by the strong boss and sharp bowing at the cusp.

Occurrence.-In the Genesee Formation in New York at localities: Tu-2, Py-15, Py-7, Nap-4, Cd-7, $\mathrm{Hy}-2, \mathrm{Cl}-4, \mathrm{Cl}-3, \mathrm{Cl}-2, \mathrm{At}-1, \mathrm{Dp}-3, \mathrm{Dp}-1, \mathrm{Ed}-2$, Ed-1, SC-1.

\section{Lonchodina typicalis Ulrich and Bassler}

Lonchodina typicalis Ulrich and Bassler, 1926, p. 31, pl. 5, fig. 1; Huddle, 1968, p. 23-24, pl. 12, figs. 14-22. 
Remarks.-See Huddle (1968) for description. Basal cavity shallow and twisted. White matter confined to the denticles, or in large specimens to the upper part of the bar.

Occurrence.-In the Genesee Formation in New York at localities: $\mathrm{Py}-7, \mathrm{Ph}-7, \mathrm{Nap}-4, \mathrm{Cd}-7, \mathrm{Cl}-4$, Cl-3, Cl-2, At-1, Dp-1, Ed-2, Ed-1, SC-1.

\section{PRIONIODINA Bassler 1925 \\ Prioniodina compressa Branson and Mehl \\ Pl. 29, figs. 5-7; pl. 31, figs. 14-21}

Prioniodina compressa Branson and Mehl, 1934a, p. 213-214, pl. 14, fig. 18; Mound, 1968, p. 512, pl. 70, fig. 11 .

Diagnosis.-The distinctive features of this element are the thin compressed bars and denticles and the twisted basal cavity with a small basal pit, and the subcentral cusp.

Description.-A more or less arched and bowed element with subequal bars and a large central cusp. The bars are thin and translucent, expanded above the basal cavity, and some specimens have ridges along the centerline of the bars. Cusp and denticles compressed, sharp edged, fused or separate, with diffuse mottled white matter extending to the base of the cusp and the top of the bars. Basal cavity shallow and twisted and has grooves extending under the bars.

$P$. compressa is similar to Bryantodus tortus in the compressed denticles, twisted basal cavity, and distribution of white matter. They may belong in the same multielement species.

Occurrence.-In the Genesee Formation in New York, this element occurs at the following localities: $\mathrm{Py}-7, \mathrm{Ph}-5, \mathrm{Ph}-1, \mathrm{Nap}-4, \mathrm{Cd}-5, \mathrm{Cl}-5, \mathrm{Cl}-4, \mathrm{Cl}-3$, $\mathrm{Dp}-3, \mathrm{Ed}-2, \mathrm{Ed}-1$.

\section{Prioniodina dialata (Bryant)}

Pl. 29, figs. 8,9 ; pl. 30, figs. $1-8$

Prioniodus dialatus Bryant, 1921, p. 20, pl. 7, figs. 3, 4, fig. 11 ?.

Prioniodus recedens Bryant, 1921, pl. 2, fig. 4, USNM 135005 [not the other specimens of $P$. recedens].

Bryantodus bezoensis Stauffer, 1938, p. 420, pl. 51, fig. 14.

Lonchodina cooperi Müller and Clark, 1967, p. 914, pl. 18, figs. 4, 12, 14 .

Lectotype.-USNM 142770, the specimen figured by Bryant (1921, pl. 7, fig. 4), North Evans Limestone of Rickard (1964), Eighteenmile Creek, N.Y.

Remarks. - This element is characterized by the very thick bar with widely spaced round denticles, and a flat base marked by strong growth lines and a twisted basal cavity. Anterior bar longer than the downward- and inward-curving posterior bar. Bar material dark colored, and the diffuse white matter extends from the denticle downward to the line of maximum thickness of the bar in mature specimens. The small, immature forms have clear bar material, oval or flattened denticles, and a moderately deep and twisted basal cavity.

Two forms make up most of the specimens placed in this element species. One form is nearly straight or slightly bowed and very little arched (nearly flat base), and the other form is strongly arched and bowed. The extremes are very different, but they seem to intergrade and are regarded as a transition series. Nearly all the specimens have a flat base and a twisted basal cavity. A few specimens assigned to this element species have thin bars with attachment areas near the bar tips and some of the denticles lack white matter.

The element probably belongs to a multielement species that includes Trichonodella blanda, B. aversus, B. tortus, Lonchodina subsymmetrica, and perhaps other form species of lonchodinan elements.

Occurrence.-This is a common species in the Genesee Formation of New York at localities: I-3, Ov-12, Wg-13, Py-14, Py-7, Ph-1, Nap-4, Cd-12, $\mathrm{Cd}-7, \mathrm{Hy}-2, \mathrm{Cl}-5, \mathrm{Cl}-4, \mathrm{Cl}-3, \mathrm{Cl}-2, \mathrm{Ba}-3, \mathrm{At}-1$, Dp-3, Dp-1, Ed-2, Ed-1, SC-1.

$$
\begin{aligned}
& \text { Prioniodina macrodenta (Bryant) } \\
& \text { Pl. 19, figs. 1, 2; pl. 28, figs. 12-17 }
\end{aligned}
$$

Prioniodus macrodentus Bryant, 1921, p. 18, pl. 8, fig. 10; not Bryantodus macrodentus (Bryant) of later authors.

Holotype.-Presumed lost. Not in USNM collections.

Remarks.-This element is characterized by coarse pustulae on lateral expansion of bars. The element is slightly arched with confluent denticles on anterior bar and discrete widely spaced denticles on posterior bar. Base of bar broad and slightly rounded with a large, round, thick-lipped basal cavity below large cusp.

This is probably the same element as Polygnathus deformis Anderson 1966. It is probably the ozarkodinan or perhaps the platform element in a multielement species including lonchodinan elements.

Occurrence.-This element occurs in the Tully Limestone, the Leicester Marcasite Member of Sutton (1951), the North Evans Limestone of Rickard (1964), and the Genundewa Limestone Member of the Genesee Formation in New York at localities: Tu-2, Cd-12, Dp-1, Ed-2, Ed-1, Amsdell Creek (R. R. Hibbard Colln., Univ. Michigan, Anderson (1966, p. 411-412) reported Polygnathus deformis from the Lime Creek Shale of Iowa. 
Prioniodina transitans (Ulrich and Bassler)

Prioniodina transitans (Ulrich and Bassler) 1926, p. 26, pl. 4, figs. 10, 11; Huddle, 1968, p. 44, pl. 1, figs. 9-12.

Remarks.-This element species of unknown affinities was previously described by me (Huddle, 1968) and the description is not repeated here.

Occurrence.-This element occurs in the Genundewa Limestone Member of the Genesee Formation at localities: Ba-3 and Ed-1; in the Middlesex Shale Member of the Sonyea Formation at the type section; and in the Rhinestreet Shale Member of the West Falls Formation at the shale pit at Weyer, N.Y.

\section{CENTROGNATHODUS Branson and Mehl 1944 \\ Centrognathodus sinuosus (Branson and Mehl)}

Centrognathus sinuosa Branson and Mehl, 1934a, p. 197, pl. 15, fig. 24.

Centrognathodus sinuosus (Branson and Mehl), 1944, p. 240, pl. 93, fig. 48.

Holotype.-C373-3, University of Missouri, Grassy Creek Shale (probably Saverton Shale fide Mehl, 1960) Sees Creek, Mo.

Remarks. - A single specimen from the Penn Yan Shale Member of the Genesee Formation, Elevenmile Creek (At-1) is referred to this element species. It agrees reasonably well with the figured specimen. C. sinuosus is probably a freak prioniodontan element with an extra bar.

\section{LOCALITY LIST}

Section Tu-2-Tinkers Falls

[South of Apulin, about 3.4 miles east of State Highway 91 near line between Cortland and Onondaga Counties. SE1/4 of Tully 15-minute quadrangle, $\mathrm{SE}$ rectangle of Tully $7 \frac{1}{2}$-minute quadrangle. Tully limestone]

USGS 9068-SD. Zone $0.3 \mathrm{ft}$ thick, 9.6-9.9 ft above base of West Brook Member of Tully Formation (or 4-4.3 ft above division " $\mathrm{H}$ ") of Cooper and Williams (1935, p. 791 ), and about 1.7-2.0 ft below top of exposed Tully Limestone. Collector, W. H. Hass; sample 6 of 10/24/53.

USGS 9070-SD. 3.8-4.5 ft below top of Tully Limestone and about $10 \mathrm{ft}$ above lip of the falls. The collection came from division " $\mathrm{H}$ " of Cooper and Williams (1935) and above the Bellona coral bed of Heckel (1973). Pharciceras from this bed and Tornoceras from beds above. Collectors, J. W. Huddle, M. R. House, and W. T. Kirchgasser; sample 4 of $9 / 6 / 66$.

USGS 6803-SD. 4.2-4.6 ft above West Brook Member of Tully Formation of Cooper and Williams (1935) of Tully Limestone (division "G"), and above Bellona coral bed of Heckel (1973). Collector, W. H. Hass; sample 5 of $10 / 24 / 53$.

USGS 6802-SD. Basal $0.4 \mathrm{ft}$ of West Brook Member of Tully Formation (division "G") of Cooper and Williams (1935, p. 791) and below Bellona coral bed of Heckel (1973). Collector, W. H. Hass; sample 4 of $10 / 24 / 53$.

USGS 9069-SD. Tully Limestone. Basal $1 \mathrm{ft}$ of division "B" in Tinkers Falls Member of Cooper and Williams (1935, p. 792) and Cuyler Bed of the "Lower Member" of
Heckel (1973). Collectors, J. W. Huddle, M. R. House, and W. T. Kirchgasser; sample 3 of $9 / 6 / 66$.

Section Dy-10-Fall Creek-Ithaca

[Cornell University campus, Ithaca East 71/2-minute quadrangle]

USGS 6798-SD. Ithaca Member, Genesee Formation, float block of calcareous fossiliferous siltstone, Beebe Limestone of Caster (1933, p. 202), $50 \mathrm{ft}$ downstream from Thurston Ave. bridge on south bank. Siltstone block is about $1.4 \mathrm{ft}$ thick and weighs several tons. The rock is medium gray, crossbedded, and contains numerous brachiopods, pelmatozoan stems, and a few corals. Collector, W. H. Hass; sample 1 of $9 / 16 / 58$.

USGS 6799-SD. Calcareous siltstone $1.3 \mathrm{ft}$ thick containing bryozoans, brachiopods, and pelmatozoan stems in the north bank. Fall Creek, about $300 \mathrm{ft}$ upstream from Caldwell Road bridge in Forest Home, Ithaca Member, Genesee Formation. Collector, W. H. Hass; sample 2 of $9 / 16 / 58$

USGS 8331-SD. Beebe Limestone of Caster (1933) (in Ithaca Member of Genesee Formation), float block in Fall Creek below Thurston Ave. bridge. The Beebe Limestone is in place at top of canyon wall near bridge. Blocks are $10.5 \times 5.5 \times 1 \mathrm{ft}$ and $7 \times 5 \times 1.5 \mathrm{ft}$. Collector, W. H. Hass; sample 6 of $5 / 7 / 59$.

\section{SECTION I-10-Renwick Brook}

[East side of Cayuga Lake between Renwick and Willow Points, Ithaca West $71 / 2$-minute quadrangle]

USGS 6790-SD. Siltstone with Warrenella laevis and other megafossils. Sherburne Flagstone Member of Genesee Formation, 46-46.5 ft below top of member. Collectors, W. H. Hass and G. W. Colton; sample 3 of 9/20/58.

\section{Section I-3-Coy Glen}

[Southwest of Ithaca on State Highway 34A, Ithaca West $7 \frac{1}{2}$-minute

USGS 6793-SD. Medium-dark-gray limestone lens containing pelmatozoan stems, gastropods, brachiopods, and other fossils, 0-0.1 ft thick about $165 \mathrm{ft}$ (hand level) above lower black shale in Renwick Shale Member of Genesee Formation. The Renwick has abundant linguloid brachiopods, and it forms the first exposure above N.Y. State Highway 34A. The exposure of limestone is along a nearly flat reach of the creekbed between two falls. The upper falls is about $20 \mathrm{ft}$ high (not vertical) about 2,900 ft (airline) northwest of N.Y. State Highway 34A bridge over Coy Glen Creek. Collector, W. H. Hass; sample 1 of $9 / 13 / 58$.

USGS 6791-SD. Top $1 \mathrm{ft}$ of Ithaca Member of Genesee Formation, $650 \mathrm{ft}$ downstream from point where Elm Street Extension crosses Coy Glen about 2 miles west of State Street bridge in. Ithaca. Calcareous coquinite lens $1 \times$ $1.5 \times 5 \mathrm{ft}$ in a siltstone sequence in the creekbed. Probably a channel fill. Collector, W. H. Hass; sample 4 of $9 / 20 / 58$.

Note.-These lenses in the Ithaca are local, and there is little stratigraphic continuity. Therefore, the local names of Beebe Limestone and Williams Brook Coquinite Member of Ithaca facies of Caster (1933) have only limited significance. (Hass field notes $9 / 20 / 58$.) 


\section{SECTION I-2-Williams Brook}

[West side of Cayuga Lake Inlet delta near N.Y. State Highway 96, Ithaca

USGS 6792-SD. 0-8 ft above base of Williams Brook Coquinite Member of Ithaca facies of Caster (1933). The outcrop is the type section of the unit. It is about $200 \mathrm{ft}$ east of N.Y. State Highway 94, opposite a house. A road leads to house on south side of Williams Brook. Collector, W. H. Hass; sample 2 of $9 / 20 / 58$.

USGS 7626-SD. Same locality as USGS $6792-S D ; 11.5-11.7$ ft above base of Williams Brook Coquinite Member of Ithaca facies of Caster (1933) (top 0.2 foot of unit). Collector W. H. Hass; sample 1 of $5 / 7 / 59)$.

USGS 7625-SD. Williams Brook Coquinite Member of Ithaca facies of Caster (1933), 8-8.3 ft above base. Collector, W. H. Hass; sample 2 of $5 / 7 / 59$.

USGS 7624-SD. 1.5-2 ft above base of Williams Brook Coquinite Member of Ithaca facies of Caster (1933). Collector, W. H. Hass; sample 3 of $5 / 7 / 59$.

USGS 7623-SD. Marathon Sandstone Member of Ithaca facies of Caster (1933), 3.3-3.7 ft above base. Unit overlies Williams Brook Coquinite Member of Ithaca facies of Caster (1933). Collector, W. H. Hass; sample 4 of $5 / 7 / 59$.

\section{Section Gen-5-Taughannock Creek}

[West side of Cayuga Lake, Ludlowville $71 / 2$-minute quadrangle, Tompkins

USGS 6781-SD. Calcareous siltstone float from rockslide in lower Sherburne Flagstone Member of Genesee Formation in right bank of Taughannock Creek about 1,000 ft upstream from N.Y. State Highway 89. Collector, W. H. Hass; sample 5 of $9 / 11 / 58$.

USGS 6789-SD. Limestone bed 5.6-5.7 $\mathrm{ft}$ above base of Geneseo Shale Member of Genesee Formation, Taughannock Creek. Collector, W. H. Hass; sample 7 of 9/11/58.

USGS 6771-SD. Geneseo Shale Member of Genesee Formation 4-4.7 ft above the base. Just above first falls above N.Y. State Highway 89 and about $500 \mathrm{ft}$ upstream from road. Collector, W. H. Hass; sample 1 of $5 / 25 / 57$.

USGS 6784-SD. Geneseo Shale Member of Genesee Formation, $1.35-2.3 \mathrm{ft}$ above base. Above falls over Tully Limestone. Collector, W. H. Hass; sample 1 of $9 / 28 / 57$.

USGS 6772-SD. Limestone lentil in Geneseo Shale Member of Genesee Formation, $0.45-1.1 \mathrm{ft}$ above base of unit. Above falls over Tully Limestone. Collector, W. H. Hass; sample 2 of $5 / 25 / 57$.

USGS 6782-SD. Tully Limestone, upper $0.6 \mathrm{ft}$ of a $3.7-\mathrm{ft}$ thick massive bed that forms surface of creekbed for several hundred feet downstream from the Geneseo-Tully contact. This collection includes rock from 1.4 to $2.0 \mathrm{ft}$ below top of Tully Limestone. Collector, W. H. Hass; sample 6 of $9 / 11 / 58$.

USGS 6786-SD. Tully Limestone, $2.45-3.15 \mathrm{ft}$ below top of formation. Collector, W. H. Hass; sample 3 of $9 / 28 / 57$.

USGS 6787-SD. Tully Limestone, $3.9-4.2 \mathrm{ft}$ below top of formation. 0.3-ft-thick bed, adjacent beds less massive. Collector, W. H. Hass; sample 4 of $9 / 28 / 57$.

USGS 6788-SD. Tully Limestone, 8.8-9.4 ft below top. Collector, W. H. Hass; sample 5 of $9 / 28 / 57$.

USGS 6778-SD. Tully Limestone, $0.0-0.5 \mathrm{ft}$ above base. Grayish-brown dense limestone. Undulating base. No sandstone or pyrite at contact with Windom Member of Moscow Shale. Collector, W. H. Hass; sample 1 of 9/11/58.

\section{Section Gen-4-0.65 mi NW. of Taughannock Point}

10.7 miles west-northwest of Taughannock Creek on N.Y. State Highway 89 at falls below the road, Ludlowville $71 / 2$-minute quadrangle, Tomkin County]

USGS 3951-SD. Lodi Limestone of Clarke (in Lincoln, 1895), Penn Yan Shale Member of Genesee Formation, 18-19 $\mathrm{ft}$ above base. This is the "False Genundewa Limestone." Collection from brink of falls. Collectors, W. H. Hass, G. W. Colton, and M. Levish; sample 1 of $8 / 24 / 56$.

USGS 6777-SD. Same locality and horizon. Collector, W. H. Hass; sample 4 of $9 / 16 / 58$.

\section{SECTION Ov-16-Quarry 1.2 mi NW. of Ovid}

[A quarry 1.2 miles north-northwest of the center of the village of Ovid and 0.6 mile west of N.Y. State Highway 96. Upper part of Geneseo

GS 565: Lodi Limestone of Clark (in Lincoln, 1895). Collector, L. V. Rickard.

GS 300: Lodi Limestone of Clark (in Lincoln, 1895). Collector, L. V. Rickard.

\section{SECTION Gen-2-Hubbard Quarry-Lively Run}

[Shale pit (Hubbard quarry) on east side of N.Y. State Highway 89 just north of Lively Run and Interlaken Beach Road; indicated with quarry
symbol on Sheldrake $71 / 2$-minute quadrangle, Seneca County. About 18 miles north of Ithaca]

USGS 6774-SD. Float from lower $6 \mathrm{ft}$ of Penn Yan Shale Member of Genesee Formation. This is the Lodi Limestone of Clarke (in Lincoln, 1895). Collector, W. H. Hass; sample 5 of $5 / 25 / 57$.

GS 299: Lodi Limestone of Clarke (in Lincoln, 1895), same quarry. Collector, J. W. Wells; loaned by L. V. Rickard, New York Geological Survey.

GS 586: Lodi Limestone of Clarke (in Lincoln, 1895), same quarry. Collector, J. W. Wells; loaned by L. V. Rickard, New York Geological Survey.

USGS 7627-SD. Concretions from upper part of Geneseo Shale Member of Genesee Formation. Collectors, John W. Huddle and Wallace de Witt, Jr.; sample 2 of 5/13/62.

\section{SeCtion Ov-10-Mill Creek-Lodi}

[On east side of Seneca Lake, south of Lodi Station, about 1.2 miles west of Lodi, Lodi $71 / 2$-minute quadrangle, Seneca County]

USGS 6768-SD. "False Genundewa Limestone" or Lodi Limestone of Clarke (in Lincoln, 1895) in Penn Yan Shale Member of Genesee Formation, about $12 \mathrm{ft}$ above base of Silver Thread Falls, 1.5-2.2 ft above top of Geneseo Shale Member of Genesee Formation. Collector, W. H. Hass; sample 1 of $9 / 5 / 58$.

\section{Section Ov-12-Tommy Creek}

[In Tommy Creek about 2.8 miles southwest of Ovid on east side of Seneca Lake, Ovid $71 / 2$-minute quadrangle, Seneca County]

USGS 6766-SD. Crosby Sandstone Member as used by Torrey and others (1932) in Ithaca Member of Genesee Formation about $97 \mathrm{ft}$ above top of Geneseo Shale Member of the Genesee in Tommy Creek. Collector, George W. Colton, August 1957.

Section Ov-13-0.3 mi N. of Tommy Creek

USGS 6767-SD. Lodi Limestone of Clarke (in Lincoln, 1895) or "False Genundewa Limestone," Penn Yan Shale Mem- 
ber of the Genesee Formation about $3 \mathrm{ft}$ above top of Geneseo Shale Member of Genesee in creek 0.3 mile north of Tommy Creek. Collectors, Georg W. Colton and W. de Witt, Jr., 10/10/58. Two examples of Polygnathus ectypus.

\section{SECTION Wg-13-Watkins Glen}

[Along Glen Creek in Watkins Glen, Beaver Dams $71 / 2-$ minute quadrangle, Chemung County]

USGS 7616-SD. $0.2 \mathrm{ft}$ carbonaceous pyrite with fossils at the contact between Milo Tongue of Grossman (1944) of West River Shale Member of Genesee Formation and Starkey Tongue of Ithaca Member of Genesee. About 73 $\mathrm{ft}$ below Grossman's Middlesex Shale Member of Sonyea Formation. The Middlesex Member exposed near top of path at upper entrance to Watkins Glen State Park. The pyrite at top of the Starkey black shale bed exposed in creek at base of stairs. Collectors, W. H. Hass, J. F. Pepper, W. de Witt, Jr., and M. Levish; sample 2 of 9/18/56.

USGS $7660-$ SD. Same locality and horizon. Pyritized styliolinas. Collector, W. H. Hass; sample 1 of $9 / 6 / 58$.

USGS 9062-SD. Fossiliferous bed 0.1-0.2 ft thick about 150 $\mathrm{ft}$ below top of Ithaca Member of Genesee. The collection was made about $200 \mathrm{ft}$ downstream from a footbridge and about $75 \mathrm{ft}$ downstream from a tunnel. Brachiopods and styliolinas present. Collector, W. H. Hass; sample 2 of $9 / 6 / 58$.

\section{SECTION Wg-1-Big Stream-Glenora Falls}

[West side Seneca Lake, Reading Center 11/2-minute quadrangle, Yates

USGS 6765-SD. Parrish Limestone Lentil of Clarke and Luther (1905), a fossiliferous silty crinoidal limestone (not the same as the type Parrish Limestone Bed in the Cashaqua Shale Member of the Sonyea Formation). Coral and phosphatic nodule zone. About $5 \mathrm{ft}$ above bed of creek in a stretch of the creek that flows north a short distance above Glenora Falls. Base of bed uneven. $500 \mathrm{ft}$ south of BM (bench mark) 689 and 2,250 ft eastnortheast of BM 834. Collectors, W. de Witt, Jr., M. J. Bergin, and W. H. Hass; sample 3 of $8 / 23 / 58$.

USGS $6770-S D$. Lenticular pyritic bed containing pteropods and coalified plants; 8-8.2 ft above base of West River Shale Member of Genesee Formation. In Big Stream, 2,000 feet west-northwest of BM 834 and $2,750 \mathrm{ft} \mathrm{SW}$ of Highway 14 road junction, 841-ft altitude. Collector, G. W. Colton, $6 / 10 / 54$.

\section{Section WG-3-South side of Fir Tree Point}

[West side of Seneen Lake in gully just south of Fir Tree Point; exposure starts in Greneseo Shale Member of the Genesee Formation and continucs upward to Crosby Sandstone Member as used by Torrey and
others (1932), Rending Center 71/2-minute quadrangle, Yates County 1

USGS 6763-SD. Limestone lentil $0.3-0.8 \mathrm{ft}$ thick, $0.7-0.8 \mathrm{ft}$ below more massive limestone $5.6 \mathrm{ft}$ thick at mouth of gully. Collector, W. H. Hass; sample 1 of 5/24/57.

USGS 3983-SD. Float from Renwick Shale Member of the Genesee Formation about $70 \mathrm{ft}$ above limestone at mouth of gully on north side of hill near top above second falls. Shale chips from black shale about $13 \mathrm{ft}$ thick.

USGS 6761-SD. Lodi Limestone of Clarke (in Lincoln, 1895) or " False Genundewa Limestone," Penn Yan Shale Member of Genesee Formation, 0-0.5 ft above Geneseo Shale
Member of Genesee. Collector, W. H. Hass; sample 3 of $9 / 6 / 58$.

USGS 6762-SD. Lodi Limestone of Clarke (in Lincoln, 1859) or "False Genundewa Limestone," Penn Yan Shale Member of Genesee. Massive limestone 5.5-6 ft above contact with Geneseo Shale Member of Genesee. Collector, W. H. Hass; sample 4 of $9 / 6 / 58$.

\section{Section Py-15-Sunset Point Gully}

[Gully at Sunset Point on east side of Keuka Lake, Keuka Lake 71/2minute quadrangle, Yates County]

USGS 6756-SD. $0-0.3 \mathrm{ft}$ above base of Crosby Sandstone Member as used by Torrey and others (1932) in the Ithaca Member of the Genesee Formation. A fossiliferous calcareous sandstone containing Manticoceras (field identification by W. H. Hass). The Crosby is at base of Ithaca Member and is about $60 \mathrm{ft}$ above lowest exposure in Sunset Gully. Collector, W. H. Hass; sample 6 of $8 / 22 / 58$

USGS 6757-SD. Zone of concretions in upper part of West River Shale Member of Genesee Formation, about $4 \mathrm{ft}$ below contact between Genesee and Sonyea Formations (West River and Middlesex Shale Members). Collector, W. H. Hass; sample 7 of $8 / 22 / 58$.

\section{SECTION Py-14-Willow Grove Gully}

[Gully at Willow Grove on east side of Keuka Lake, Keuka Lake 71/2minute quadrangle, Yates County]

USGS 6758-SD. Calcareous layer over and around concretions, $0.05 \mathrm{ft}$ thick and containing styliolinas, $25 \mathrm{ft}$ above base of Ithaca Member of Genesee Formation in north fork of Willow Point Gully (higher falls in the south fork). Collectors, W. H. Hass and G. W. Colton; sample 1 of $5 / 22 / 57$.

USGS 6759-SD. Calcareous nodular siltstone containing styliolinas and other fossils $0-0.2 \mathrm{ft}$ above base of Crosby Sandstone Member of Standish Formation as used by Torrey and others (1932) at base of Ithaca Member of Genesee, below bank in the gully. Collectors, W. H. Hass and G. W. Colton; sample 2 of $5 / 22 / 57$.

\section{Section Py-7-Chidsey Point Gully}

[Gully leading from Chidsey Point on west side of West Branch of Keuka Lake, 1.7 miles south of Branchport, Pulteney $71 / 2$-minute quadrangle, Steuben County]

USGS 6754-SD. West River Shale Member of Genesee Formation. Zone of small calcareous concretions 22-22.5 ft below contact between Genesee and Sonyea Formations. The middle one of three siltstones and the only one containing calcareous concretions, 0.5-2 ft in diameter in face of streambank. Collectors, W. H. Hass and W. de Witt, Jr.; sample 2 of $9 / 27 / 57$.

USGS 6752-SD. Concretions 28.5-29 ft below contact of Genesee and Sonyea Formations. Collector, W. H. Hass; sample 6 of $8 / 20 / 58$.

USGS 6750-SD. Calcareous concretion $42-43 \mathrm{ft}$ below Genesee-Sonyea contact. Collector, W. H. Hass; sample 3 of $8 / 20 / 58$.

USGS 6749-SD. Concretionary bed 62-63 ft below GeneseeSonyea contact; brownish-gray, silty with sandy fossiliferous layers. About $13 \mathrm{ft}$ above Bluff Point Siltstone Bed of West River Shale Member of Genesee Formation. Concretions $0.9-3 \mathrm{ft}$ in cross section in streambank. Numerous small cephalopods present, Mantico- 
ceras? (field identification by Hass). Collector, W. H. Hass; sample 1 of $8 / 20 / 58$.

USGS 6753-SD. Concretions zone 73-74 ft below GeneseeSonyea contact and $2 \mathrm{ft}$ above Bluff Point Siltstone Bed of West River Shale Member of Genesee Formation. Concretions $0.5-1.5 \mathrm{ft}$ in diameter. Collectors, W. H. Hass and W. de Witt, Jr.; sample 1 of $9 / 27 / 57$.

USGS $6747-S D$. Zone of discoidal concretions $2 \times 2 \times 0.5$ $\mathrm{ft} ; 2.2-2.7 \mathrm{ft}$ below Bluff Point Siltstone Bed of West River Shale Member of Genesee Formation or 72.2-77.7 ft below Genesee-Sonyea contact. Collector, W. H. Hass; sample 2 of $9 / 8 / 58$.

USGS 8556-SD. Calcareous siltstone with limy nodules $0.1 \times$ $0.2 \times 0.05 \mathrm{ft}, 15-15.6 \mathrm{ft}$ below Bluff Point Siltstone Bed of West River Shale Member of Genesee Formation and approximately $85-85.6 \mathrm{ft}$ below Genesee-Sonyea contact. Pelecypods, goniatites, and straight cephalopods.

USGS 8957-SD. Zone of small calcareous nodules; maximum, $1 \times 0.3 \times 0.2 \mathrm{ft} ; 24.5-25.5 \mathrm{ft}$ below Bluff Point Siltstone Bed of West River Shale Member of Genesee Formation and approximately $100 \mathrm{ft}$ below Genesee-Sonyea contact. Collector, W. H. Hass; sample 2 of $5 / 6 / 59$.

\section{SeCtion Ph-7-Kashong Creek-Bellona} [In Kashong Creek above and below bridge in Bellona, section starting at
base of falls and old mill dam downstream from Pre-Emption Road, about $61 / 2$ miles south of Geneva. Stanley $71 / 2-$ minute quadrangle, Yates County]

USGS 6742-SD. Dark-gray calcareous nodule, $0.15 \times 1 \mathrm{ft}$; 1.75-1.9 ft above base of Geneseo Shale Member of Genesee Formation. About 2,000 fi upstream from bridge. Collectors, W. H. Hass and W. de Witt, Jr.; sample 1 of $8 / 22 / 58$ (single specimen, maybe contamination.)

USGS 6741-SD. Leicester Marcasite of Sutton 1951, 0-0.1 ft thick. Small pods or patches tightly cemented to top of Tully Limestone. A calcitic, pyritic sandstone containing crinoid stems and brachiopods. In bed of Kashong Creek about $1,500 \mathrm{ft}$ upstream from bridge. Thin stringers of calcitic sandstone occur in basal $2 \mathrm{ft}$ of Geneseo Shale Member of Genesee Formation. Collector, W. H. Hass; sample 3 of $9 / 8 / 58$.

USGS 7617-SD. Same locality and bed as 6741-SD. Bellona coral bed of Heckel 1973 is $0.8 \mathrm{ft}$ below top of Tully Limestone here. Collector, W. H. Hass; sample 3 of $9 / 8 / 58$.

USGS 6744-SD. Top $0.2 \mathrm{ft}$ of Tully Limestone (or 6.8-7 ft above base) in Kashong Creek. Collector, W. H. Hass; sample 3 of $9 / 23 / 57$.

USGS 6743-SD. 4-4.6 ft above base of Tully Limestone in Kashong Creek. Collector, W. H. Hass; sample 2 of $9 / 23 / 57$.

USGS 6740-SD. $3.1-4 \mathrm{ft}$ above base of Tully Limestone. Collector, W. H. Hass; sample 4 of $8 / 21 / 58$.

USGS 6739-SD. 0-0.3 ft above base of Tully Limestone. Collector, W. H. Hass; sample 3 of $8 / 21 / 58$.

Sectron Ph-3-Tributary of Flint Creek $0.3 \mathrm{mi}$ S. of Gorham [Flint Creek, 2,000 ft south of crossroads in Gorham, Rushville 71/2-

USGS 8958-SD. Sandy pyrite lens on top of Bellona coral bed of Heckel (1973) (Tully Limestone). Corals eroded. Blocks thrown up from creekbed during quarrying for road metal (not shown on sections in de Witt and Colton, 1977). Collector, W. H. Hass; sample 1 of $5 / 11 / 59$.

\section{SeCtion Ph-5-0.8 mi N. of Shuman Cemetery}

[Flint Creek tributary, 4,000 ft north of Shuman Cemetery on East Swamp Road and about 2 miles south of Gorham. Genundewa Limestone Mem71/2-minute quadrangle, Ontario County]

USGS 6736-SD. Genundewa Limestone Member of the Genesee. $0.3 \mathrm{ft}$ thick. Easternmost exposure of the member. Collectors, W. H. Hass and W. de Witt, Jr.; sample 3 of $9 / 26 / 57$.

\section{SeCtion Ph-6-0.3 mi W. of Babbitt Corner}

[Tully Limestone exposed in Fish Creek on both sides of road. 0.35 mile west of Babbitt Corner and 1.15 miles east of Reed Corners on Depew County]

USGS 6734-SD. Tully Limestone south of road; $3.2 \mathrm{ft}$ thick. Whole bed sampled. Collectors, W. H. Hass and W. de Witt, Jr.; sample 4 of $9 / 26 / 57$.

\section{Section Ph-1-Washburn Cemetery}

[Outcrops in streambed (Voorhys Gully) 1,000 ft east of Washburn Cemetery on Conklin Road, about 2 miles north of Rushville, wesc USGS 6737-SD. Genundewa Limestone Member of Genesee Formation, 0- to $0.4-\mathrm{ft}$ thickness exposed in creekbed about $650 \mathrm{ft}$ south of Conklin Road. Collector, W. H. Hass; sample 9 of $5 / 23 / 57$.

\section{Section Near Ph-1-Voorhys Gully}

[Tully Limestone outcrop at culvert about 20 west of road; about 3 miles north of Rushville and about 0.4 mile north of Washburn Cemetery. West-central rectangle, Rushville, $71 / 2$-minute quadrangle, Ontario County ] USGS 6730-SD. 2.3-2.5 ft above base of Tully Limestone. Collector, W. H. Hass; sample 1 of $9 / 24 / 57$.

USGS 6720-SD. Tully Limestone, 0-0.4 ft above undulating base. Collector, W. H. Hass; sample 1 of 8/21/58.

USGS 6721-SD. Windom Member of Moscow Shale; gray, calcareous fossiliferous siltstone $12-12.5 \mathrm{ft}$ below Tully Limestone. Collector, W. H. Hass; sample 2 of 8/21/58.

\section{Sectron Cd-12-Gage Gully}

[Gully on east side of Canandaigua Lake entering the lake at Gooding Point; about 2,000 ft along stream from State Highway 364 and $500 \mathrm{ft}$ west of road]

USGS 8960-SD. Concretions $4 \times 2 \times 0.5 \mathrm{ft}$, about $0.5-1 \mathrm{ft}$ below top of Geneseo Shale Member of Genesee Formation. Collector, W. H. Hass; sample 3 of $5 / 11 / 59$.

USGS 6732-SD. Leicester Marcasite Member of Moscow Formation of Sutton (1951), 0-0.5 ft thick, overlying Tully Limestone, 200-250 ft downstream from fork in Gage Gully. Collector, W. H. Hass; sample 1 of 9/19/57.

USGS 6733-SD. Tully Limestone, 0-0.6 ft above base (entire thickness). This westernmost exposure of the Tully Limestone is below the Leicester Marcasite Member of Moscow Formation of Sutton (1951) here. About $350 \mathrm{ft}$ downstream from fork in Gage Gully. Collectors, W. H. Hass and W. de Witt, Jr.; sample 1 of 9/26/57.

USGS 8959-SD. Windom Member of Moscow Shale; zone of calcareous nodules $9-9.3 \mathrm{ft}$ below top of member. Collector, W. H. Hass; sample 2 of $5 / 11 / 59$.

USGS 6722-SD. Calcareous bed in Windom Member of Moscow Shale about $60 \mathrm{ft}$ bəlow top of member. Collector, W. H. Hass; sample 1 of $9 / 20 / 57$. 


\section{SECTION Nap-5-Corry Gully}

[0.4 mile south of Pine Corners and 2.8 miles north of Middlesex on State Highway 245, in northeast rectangle of Middlesex $7 \frac{1}{2}$-minute quadrangle, Yates County]

USGS 6724-SD. Silty dolomitic limestone 0.2-0.5 ft below top of Genundewa Limestone Member of Genesee Formation. Collector, W. H. Hass; sample 2 of $9 / 25 / 57$.

USGS 6725-SD. Limestone bed $0.31 \mathrm{ft}$ thick at base of Genundewa Limestone Member of Genesee Formation. Collector, W. H. Hass; sample 3 of $9 / 25 / 57$.

USGS 6726-SD. Limy bed $0.3 \mathrm{ft}$ thick in Penn Yan Shale Member of Genesee Formation 1.9-2.2 ft below top of member. Collector, W. H. Hass; sample 4 of $9 / 25 / 57$.

\section{Sectron Nap-4-Genundewa Point}

[East side Canandaigua Lake east-southeast of Seneca Point about 0.9 mile north of Willow Grove Point on west flank of Genundewa Hil (labeled Bare Hill on map) in north

USGS 3982-SD. Black shale about $27 \mathrm{ft}$ above Genundewa Limestone Member-West River Shale Member contact in Genesee Formation. Collector, W. H. Hass; sample 8 of $5 / 21 / 57$.

USGS 3952-SD. Genundewa Limestone Member of Genesee Formation; $0.6-0.8 \mathrm{ft}$ below top. Contains abundant styliolinas. Collector, W. H. Hass; sample 1 of $9 / 12 / 56$.

USGS 3958-SD. Genundewa Limestone Member of Genesee Formation; 1.3-1.7 ft below top. The lower of two beds composed mainly of limestone containing abundant styliolinas. Collector, W. H. Hass; sample 2 of $9 / 12 / 56$.

USGS 6718-SD. 1.7-2.2 ft below top of Penn Yan Shale Member of Genesee Formation. Collector, W. H. Hass; sample 2 of $9 / 18 / 57$.

USGS 6715-SD. 6.9-7.3 ft below top of Penn Yan Shale Member of Genesee Formation. Collector, W. H. Hass; sample 2 of $9 / 18 / 57$.

USGS 6731-SD. Calcareous nodules with styliolinas and other megafossils. 8.7-9.3 ft below top of Penn Yan Shale Member of Genesee Formation. Collector, W. H. Hass; sample 1 of $10 / 1 / 57$.

USGS 6716-SD. Calcareous nodules 10.9-11.1 ft below top of Penn Yan Shale Member of Genesee Formation. Collector, W. H. Hass; sample 3 of $9 / 18 / 57$.

USGS 6719-SD. Large calcareous concretions, $3.5 \times 1.3$ $\times 1.5 \mathrm{ft} ; 14.5-15.5$ and $23.5-24.5 \mathrm{ft}$ below top of Penn Yan Shale Member of Genesee Formation. Collector, W. H. Hass; sample 1 of $8 / 27 / 58$.

\section{SECTION Cd-7-Menteth Gully}

[West side of Canandaigua Lake in central rectangle, Canandaigua Lake $71 / 2-$ minute quadrangle, Ontario County]

USGS 3950-SD. Uppermost $0.2 \mathrm{ft}$ of Genundewa Limestone Member of Genesee Formation. Collectors, W. H. Hass, G. W. Colton, and M. Levish; sample 7 of $8 / 21 / 56$

USGS 3949-SD. 0.2-ft-thick limestone bed $9 \mathrm{ft}$ below top of Genundewa Limestone Member of Genesee Formation, $72 \mathrm{ft}$ above base of Penn Yan Shale Member of Genesee Formation. Collectors, W. H. Hass, G. W. Colton, and M. Levish; sample 6 of $8 / 21 / 56$.

USGS 3959-SD. Calcareous bed in Penn Yan Shale Member of Genesee Formation 65.8-66 ft above base of member and about $17 \mathrm{ft}$ below top of Genundewa Limestone Member of Genesee Formation. Collectors, W. H. Hass, G. W Colton, and M. Levish; sample 5 of $8 / 21 / 56$.
USGS 6708-SD. Large concretions, $2 \times 3 \times 3 \mathrm{ft}$, in Penn Yan Shale Member of Genesee Formation, 21.5-22 ft below top of Genundewa Limestone Member of Genesee and $60 \mathrm{ft}$ above base of Penn Yan Shale Member. Collector, W. H. Hass; sample 2 of $8 / 26 / 58$.

USGS 3964-SD. Calcareous siltstone 0.23-0.25 ft thick, 36 ft below top of Genundewa Limestone Member of Genesee Formation and about $45 \mathrm{ft}$ above base of Penn Yan Shale Member of Genesee. Collectors, W. H. Hass, G. W. Colton, and M. Levish; sample 4 of $8 / 21 / 56$.

USGS 6709-SD. Same bed as USGS 3964-SD, about $45 \mathrm{ft}$ above base of Penn Yan Shale Member of Genesee Formation. Collector, W. H. Hass; sample 3 of $8 / 26 / 58$.

USGS 6713-SD. Calcareous siltstone about 35-35.5 ft above base of Geneseo Shale Member of Genesee Formation, about 1-1.5 ft above a zone of large concretions, USGS 6699-SD. Collector, W. H. Hass; sample 5 of $8 / 25 / 58$.

USGS 6699-S.D. Zone of large flat concretions, $1 \times 2 \times 2 \mathrm{ft}$, about 33-34 ft above base of Geneseo Shale Member of Genesee Formation. Collector, W. H. Hass; sample 3 of $8 / 25 / 58$.

USGS 6703-SD. Calcareous black shaly siltstone containing concretions about 26-26.5 ft above base of Geneseo Shale Member of Genesee Formation. Collector, W. H. Hass; sample 6 of $9 / 25 / 57$.

USGS 6702-SD. Siltstone 24-24.5 ft above base of Geneseo Shale Member of Genesee Formation. Collector, W. H. Hass; sample 7 of $9 / 25 / 57$.

USGS 3953-SD. Conodonts in black shale at zone of flat calcareous nodule concretions, $0.5 \times 1.5 \times 3 \mathrm{ft}$ about 14 $14.5 \mathrm{ft}$ above base of Geneseo Shale Member of Genesee Formation. Collectors, W. H. Hass, G. W. Colton, and M. Levish; sample 2 of $8 / 21 / 56$.

USGS 3955-S.D. Black shale 0.1-0.2 ft above base of Geneseo Shale Member of Genesee Formation. Collectors, W. H. Hass, G. W. Colton, and M. Levish; sample 1 of 8/21/56.

USGS 6704-SD. Black shale 0-1.3 ft above base of Geneseo Shale Member of Genesee Formation. Collector, W. H. Hass; sample 1 of $5 / 23 / 57$.

USGS 6705-SD. Leicester Marcasite Member of Moscow Formation of Sutton (1951) in lenses as much as 0.03 $\mathrm{ft}$ thick at contact of Windom Member of Moscow Shale and overlying Geneseo Shale Member of Genesee Formation. Collector, W. H. Hass; sample 3 of $9 / 20 / 57$.

Section Cd-5-Wilder Run at Bristol Center

[Center Gully (Wilder Run of earlier reports). East of Bristol Center and N.Y. State Highway 64, Bristol Center $7 \frac{1}{2}-$ minute quadrangle, Bristo Township, Ontario County]

USGS 6670-SD. Concretionary limestone bed 13.6-13.95 ft below top of West River Shale Member of Genesee Formation. Collector, W. H. Hass; sample 3 of $8 / 27 / 58$.

USGS 3976-SD. Black shale 19-19.3 ft below top of West River Shale Member of Genesee Formation. Collector, W. H. Hass; sample 1 of $9 / 13 / 56$.

USGS 4878-SD. Large septarian concretions, 22-22.7 $\mathrm{ft}$ below top of West River Shale Member of Genesee Formation. Collector, W. H. Hass; sample 2 of $8 / 27 / 58$.

USGS 3977-SD. Black shale 29.9-30.3 ft below top of West River Shale Member of Genesee Formation. Collector, W. H. Hass ; sample 2 of $9 / 13 / 56$.

USGS 4877-SD. Genundewa Limestone Member of Genesee Formation, 0.2-0.3 ft below top. Collector, W. H. Hass; sample 1 of $9 / 14 / 56$. 
USGS 6672-SD. Top $0.3 \mathrm{ft}$ of Genundewa Limestone Member of Genesee Formation. (This collection is from downstream end of Genundewa Limestone Member outcrop; USGS 4877-SD is from the upstream end.) The Genundewa dips with the stream gradient and rolls slightly.

USGS 4875-SD. Penn Yan Shale Member of Genesee Formation; calcareous bed 8-8.2 ft below top of Genundewa Limestone Member. Collector, W. H. Hass; sample 2 of $8 / 23 / 56$.

\section{Section Hy-6-0.3 mi N. of Abbey Gulf}

[Tributary to Honeoye Creek 0.3 miles north of Abbey Gulf and about 1.8 miles north of road junction of N.Y. State Highway $20 \mathrm{~A}$ and Allens rangle, Ontario County. Outcrop is 650-675 ft east of Allens Hill Road in creekbed and cliff face]

USGS 4876-SD. Leicester Marcasite Member of Moscow Formation of Sutton (1951). A calcareous pyritic bed as much as $0.1 \mathrm{ft}$ thick at contact between Windom Member of Moscow Shale and Geneseo Shale Member of Genesee Formation. Collector, W. H. Hass; sample 1 of 9/22/57. (For stratigraphic position of collection, see Abby Gulf Section ( $\mathrm{Hy}-5)$, figure 3 of de Witt and Colton (1979).)

\section{Section Hy-2-Hemlock Outlet}

[Big Tree Road, cuts on east side of Hemlock Outlet; about 0.9 airline mile northeast of Hemlock, near BM. 886 , west-central rectangle, Honeoye $71 / 2$-minute quadrangle, Livingston County. Middlesex Shale Member of let. Site of former town of Jacksonville]

USGS 6674-SD. Calcareous nodule zone about $9.5 \mathrm{ft}$ below contact between West River Shale Member of Genesee Formation and Middlesex Shale Member of Sonyea Formation. Collector, W. H. Hass; sample 3 of $8 / 25 / 56$.

USGS $6673-S D$. Basal $0.1 \mathrm{ft}$ of 0.5 -ft-thick black shale about $17 \mathrm{ft}$ below top of West River Shale Member of Genesee Formation. Collector, W. H. Hass; sample 2 of $8 / 25 / 56$.

\section{SECTION Cl-4-Fall Brook}

[Gorge of Fall Brook below the main falls, above and below N.Y. State Highway 63, south-central rectangle Geneseo $71 / 2-$ minute quadrangle,

USGS 8122-SD. Brownish-gray calcareous siltstone 7-7.15 ft above base of West River Shale Member of Genesee Formation. Contains abundant styliolinas. Collector, W. H. Hass; sample 2 of $9 / 21 / 57$.

USGS 6690-SD. Brownish-gray calcareous siltstone 2.9-3 ft above base of West River Shale Member of Genesee Formation. Collector, W. H. Hass; sample 1 of $9 / 21 / 57$.

USGS 6680-SD. Genundewa Limestone Member of Genesee Formation along path starting near brink of falls and leading to bottom of gorge, $0.5-0.9 \mathrm{ft}$ below top of member (basal $0.4 \mathrm{ft}$ of solid ledge). Collector, W. H. Hass; sample 6 of $9 / 2 / 58$.

USGS 3963-SD. Limestone $0.3-0.4 \mathrm{ft}$ thick in Penn Yan Shale Member of Genesee Formation, 1.9-2 ft below undulating contact with Genundewa Limestone Member along trail leading from brink of falls to bottom of gorge. Collector, W. H. Hass; sample 5 of 10/16/53.

USGS $6679-S D$. Same locality and bed as USGS 3963-SD. Collector, W. H. Hass; sample 5 of $9 / 2 / 58$.

USGS 6678-SD. Limestone bed, $0.2 \mathrm{ft}$ thick, the Penn Yan Shale Member of Genesee Formation along trail farthest from brink of falls and about $30 \mathrm{ft}$ below contact with Genundewa Limestone Member. Collector, W. H. Hass; sample 4 of $9 / 2 / 58$.

USGS 6692-SD. Limestone bed $0.3 \mathrm{ft}$ thick in Penn Yan Shale Member of Genesee Formation, 22.8-23.1 ft above contact of Geneseo Shale Member of Genesee Formation with Windom Member of Moscow Shale. Collector, W. H. Hass; sample 4 of $9 / 1 / 58$.

USGS 6693-SD. Limestone bed $0.2 \mathrm{ft}$ thick in Penn Yan Shale Member of Genesee Formation, 20.5-20.7 ft above base of Geneseo Shale Member of Genesee Formation. Collector, W. H. Hass; sample 3 of $9 / 1 / 58$.

USGS 6691-SD. Prominent limestone bed $0.5-0.8 \mathrm{ft}$ thick near base of Penn Yan Shale Member of Genesee Formation, 11.5-12 ft above base of Geneseo Shale Member of Genesee Formation. Collector, W. H. Hass; sample 2 of $9 / 1 / 58$.

USGS 6688-SD. Black shale from the basal $1 \mathrm{ft}$ of Geneseo Shale Member of Genesee Formation about $400 \mathrm{ft}$ downstream from main falls of Fall Brook. Collector, W. H. Hass; sample 3 of $10 / 16 / 53$.

USGS 6677-SD. Leicester Marcasite Member of Moscow Formation of Sutton (1951), 0-0.5 ft thick, from streambank about $200 \mathrm{ft}$ downstream from base of main falls. Collector, W. H. Hass; sample 3 of $9 / 2 / 58$.

USGS 6675-SD. Calcareous siltstone bed, $0.3 \mathrm{ft}$ thick, in bed of Falls Creek about $200 \mathrm{ft}$ downstream from base of falls and bend in the gorge and about $32 \mathrm{ft}$ below contact of Moscow Shale and Genesee Formation. Collector, W. H. Hass; sample 1 of $9 / 2 / 58$.

\section{SeCtion Cl-5-Dewey Hill on U.S. Highway $20 \mathrm{~A}$}

[N.Y. State Highway 20A roadcuts about 1 mile south of Geneseo; about ft west of junction with N.Y. Hikhway 63; east of Genesee River County?

USGS 8962-SD. Genundewa Limestone Member of Genesee Formation, 0.6-1 ft above base. Collector, J. W. Huddle; sample 2 of $9 / 3 / 66$.

USGS 6681-SD. Genundewa Limestone Member of Genesee Formation, 1.8-2 ft above base (top of member). Collector, W. H. Hass; sample 7 of $9 / 2 / 58$.

USGS 8961-SD. Nodular limestone, $0-0.3 \mathrm{ft}$ above base of Genundewa Limestone Member of Genesee Formation. Collector, J. W. Huddle; sample 1 of 9/3/66.

USGS 8663-SD. Brownish-gray lenticular concretionary limestone, 0.3 thick, in Penn Yan Shale Member of Genesee Formation, 1.7-2 ft below Genundewa Limestone Member. Collector J. W. Huddle; sample 3 of 9/3/66.

USGS 6682-SD. Penn Yan Shale Member of Genesee Formation. Medium-dark-brownish-gray limestone $0.2 \mathrm{ft}$ thick, 9.5-9.7 ft below Genundewa Limestone Member. Collector, W. H. Hass; sample 8 of $9 / 2 / 58$.

USGS 6683-SD. Penn Yan Shale Member of Genesee Formation. Limestone, $0.25 \mathrm{ft}$ thick, $13.7-13.95 \mathrm{ft}$ below Genundewa Limestone Member. Collector, W. H. Hass; sample 9 of $9 / 2 / 58$.

USGS 6684-SD. Penn Yan Shale Member of Genesee Formation. Nodular limestone with wavy bedding, $0.3 \mathrm{ft}$ thick, containing a few styliolinas; about $22 \mathrm{ft}$ below Genundewa Limestone Member. Collector, W. H. Hass; sample 10 of $9 / 2 / 58$.

USGS 6685-SD. Penn Yan Shale Member of Genesee Formation. Limestone with wavy bedding and styliolinas; $0.25 \mathrm{ft}$ thick about $25 \mathrm{ft}$ below Genundewa Limestone 
Member of Genesee Formation. Collector, W. H. Hass; sample 11 of $9 / 2 / 58$.

USGS 6686-SD. Penn Yan Shale Member of Genesee Formation. Limestone, 0.2-0.3 ft thick, medium-gray, aphanitic. About $27 \mathrm{ft}$ below Genundewa Limestone Member of Genesee Formation. Goniatites were collected from this bed by Michael House in 1966, and the bed was sampled for conodonts by J. W. Huddle; sample 4 of $9 / 3 / 66$. Collector, W. H. Hass; sample 12 of $9 / 2 / 58$.

USGS 6687-SD. Penn Yan Shale Member of Genesee Formation. Coalescing concretions, about $0.4 \mathrm{ft}$ thick, containing styliolinas, about $32 \mathrm{ft}$ below Genundewa Limestone Member of Genesee Formation. Collector, W. H. Hass; sample 13 of $9 / 2 / 58$.

\section{SeCtion Cl-3-Beards Creek}

[Type locality of Leicester Marcasite Member of Moscow Formation of of Ion (1951). Section measured along Beards Creek north and west minute quadrangle. Livingston County. The Leicester crops out in the creckbank about 2,700 ft west of N.Y. State Highway 36. The Genundewa Limestone Member of the Genesee Formation crops out near bridge over Benrds Creek on Dunkley Road northwest of Leicester, and the West River Shnle Member of the Genesee crops out upstream from this bridge !

USGS 8966-SD. Black shale about $10 \mathrm{ft}$ below top of West River Shale Member of Genesee Formation. Collector, W. H. Hass; sample 2 of $5 / 12 / 59$.

USGS 6695-SD. Uppermost of three calcareous siltstones about $0.1 \mathrm{ft}$ thick, $6 \mathrm{ft}$ above base of West River Shale Member of Genesee Formation. Collectors, W. H. Hass and G. W. Colton; sample 1 of 9/19/58.

USGS 6696-SD. Lowermost of the three calcareous siltstones in West River Shale Member of Genesee Formation, 1.6$1.7 \mathrm{ft}$ above Genundewa Limestone Member of Genesee Formation. Collectors, W. H. Hass and G. W. Colton; sample 2 of $9 / 19 / 58$.

USGS 8964-SD. Limestone bed, $0.2 \mathrm{ft}$ thick, immediately above a ropy bed, $1.5 \mathrm{ft}$ thick, from which Michael House collected Probeloceras. This bed is above the lip of the falls and probably is in the lower part of the West River Shale Member of the Genesee Formation, but might be included in the Genundewa Limestone Member of the Genesee. Collectors, J. W. Huddle, Michael House, and W. T. Kirchgasser; sample 6 of 9/2/66.

USGS 6694-SD. Leicester Marcasite Member of Moscow Formation of Sutton (1951), 0-0.5 ft thick, averaging about $0.2 \mathrm{ft}$ composed of calcareous sandstone, pyrite, and pyritized fossils; crossbedded in places. Collector, W. H. Hass; sample 1 of $9 / 16 / 57$.

\section{Section Cl-2-Taunton Gully}

[West of N.Y. State Highway 36, 1.6 miles north of Leicester, east-central rectangle of the Leicester $71 \%$-minute quadrangle, Livingston County. inter gully where a secondary road crosses Taunton Gully 5,000 ft

USGS 4586-SD. Genundewa Limestone Member of Genesee Formation, brownish-gray aphanitic argillaceous limestone containing styliolinas, $0.9 \mathrm{ft}$ thick, at lip of falls just below bridge. Collector, W. H. Hass; sample 7 of $5 / 19 / 57$.

USGS 4585-SD. Nodular limestone bed about $8 \mathrm{ft}$ below Genundewa Limestone Member of Genesee Formation and $1 \mathrm{ft}$ above USGS 4591-SD in Penn Yan Shale Member of Genesee Formation. Collector, W. H. Hass; sample 6 of $5 / 19 / 57$.
USGS 4591-SD. Brownish-gray limestone, 0.2-0.3 ft thick, $9 \mathrm{ft}$ below Genundewa Limestone Member of Genesee Formation in Penn Yan Shale Member of Genesee Formation. Collector, W. H. Hass; sample 4 of $9 / 16 / 57$.

USGS $4592-S D$. Limestone and concretion zone, $0.2-0.6 \mathrm{ft}$ thick, about $16 \mathrm{ft}$ below top of Genundewa Limestone Member of Genesee Formation in Penn Yan Shale Member of Genesee Formation. Collector, W. H. Hass; sample 5 of $9 / 16 / 57$.

USGS 4584-SD. Argillaceous limestone, $0.2 \mathrm{ft}$ thick, in Penn Yan Shale Member of Genesee Formation about $50 \mathrm{ft}$ above base of Geneseo Shale Member of Genesee Formation and about $18 \mathrm{ft}$ below Genundewa Limestone Member of Genesee. Collector, W. H. Hass; sample 5 of $5 / 19 / 57$.

USGS 4583-SD. Nodular limestone, about $1.15 \mathrm{ft}$ thick, between two black shales in Penn Yan Shale Member of Genesee Formation, about $31 \mathrm{ft}$ above base of Geneseo Shale Member of Genesee Formation. Collector, W. H. Hass; sample 4 of $5 / 19 / 57$.

USGS 4594-SD. Nodular calcareous bed about $1 \mathrm{ft}$ below USGS 4583-SD in Penn Yan Shale Member of Genesee Formation $23 \mathrm{ft}$ above base of Geneseo Shale Member of Genesee. Collector, W. H. Hass; sample 15 of 9/2/58.

USGS 4590-SD. Limestone bed, $0.9 \mathrm{ft}$ thick, in Penn Yan Shale Member of Genesee Formation, about $15 \mathrm{ft}$ above base of Geneseo Shale Member of Genesee Formation. Collector, W. H. Hass; sample 3 of $9 / 16 / 57$.

USGS $8968-S D$. Same bed as USGS 4590-SD. Collector, W. H. Hass; sample 6 of $5 / 12 / 59$.

USGS 4582-SD. Coquinite, containing styliolinas and brachiopods, about one-fourth inch thick, in Penn Yan Shale Member of Genesee Formation about $6 \mathrm{ft}$ above base of Geneseo Shale Member of Genesee Formation. 1 inch above USGS 4581-SD. Collector, W. H. Hass; sample 2 of $5 / 19 / 57$.

USGS 8967-SD. Limestone bed same as USGS 4582-SD. Collector, W. H. Hass; sample 5 of $5 / 12 / 59$.

USGS 4581-SD. Limestone and calcareous shale, 8.7-9.2 ft above base of Genesee Formation. Collector, W. H. Hass; sample 1 of $5 / 19 / 57$.

USGS 4589-SD. Leicester Marcasite Member of Moscow Formation of Sutton (1951), 0-0.35 ft thick. A calcareous sandy pyritic bed containing megafossils, between Windom Member of Moscow Shale and Geneseo Shale Member of Genesee Formation. Collector, W. H. Hass; sample 2 of $9 / 16 / 57$.

\section{Section Ba-5-0.75 mi N.W. of Pavilion}

Roadcut on N.Y. State Highway 63 northwest of Pavilion, about 0.3 mile Roadcut on N.Y. State Highway 63 northwest of Pavilion, about 0.3 mile
northwest of bridge over Oatka Creek. Southeast rectangle of Stafford $7 \%$-minute quadrangle]

USGS 4588-SD. Calcareous nodule zone $0.4 \mathrm{ft}$ thick, in Penn Yan Shale Member of Genesee Formation about $18 \mathrm{ft}$ above base of Geneseo Shale Member of Genesee Formation. Collector, W. H. Hass; sample 8 of $5 / 20 / 57$.

USGS 4587-SD. Limestone bed in Penn Yan Shale Member of Genesee Formation, 11.4-11 ft above base of Genesee Formation. Collector, W. H. Hass; sample 7 of 5/20/57. 


\section{Section Ba-3-Bethany Center}

[Roadcut on N.Y. State Highway 20 beneath bridge over the highway on Center Road in the southeast rectangle of Batavia South $71 / 2$-minute quadrangle 1

USGS 4595-SD. Top $0.1 \mathrm{ft}$ of Genundewa Limestone Member of Genesee Formation; abundant styliolinas. Collector, W. H. Hass; sample 1 of $5 / 20 / 57$.

USGS 8970-SD. Genundewa Limestone Member of Genesee Formation, 0.4-1 ft above base. Collectors, J. W. Huddle, Michael R. House, and W. T. Kirchgasser; sample 11 of 9/2/66.

USGS 4596-SD. Basal $0.4 \mathrm{ft}$ of Genundewa Limestone Member of Genesee Formation; abundant styliolinas. Collector, W. H. Hass; sample 2 of $5 / 20 / 57$.

USGS 4597-SD. Limestone bed, $0.3 \mathrm{ft}$ thick, in Penn Yan Shale Member of Genesee Formation, 6.1-6.4 ft below Genundewa Limestone Member of Genesee. Collector, W. H. Hass; sample $1 \mathrm{~A}$ of $9 / 3 / 58$.

\section{Section Ba-2-Linden (at the powerline)}

[Creekbank of Little Tonawanda Creek and the bed of a tributary 0.2 mile downstream from falls at Linden, beneath a power transmission

USGS 4873-SD. Penn Yan Shale Member of Genesee Formation, limestone from a nodular concretionary zone about $0.5 \mathrm{ft}$ thick, about $7 \mathrm{ft}$ below Genundewa Limestone Member of Genesee and about $2 \mathrm{ft}$ below a persistent limestone ledge that forms lip of the lower of two falls in the tributary. Collector, W. H. Hass; sample 8 of $9 / 17 / 57$.

USGS 4598-SD. Limestone in Penn Yan Shale Member of Genesee Formation, 9.3-9.7 ft above base of Geneseo Shale Member of Genesee. Collector, W. H. Hass; sample 9 of $9 / 3 / 58$.

USGS 4871-SD. Penn Yan Shale Member of Genesee Formation, brownish-black limestone, 6.2-6.5 ft above base of Geneseo Shale Member of Genesee Formation. Contains a few styliolinas. Collector, W. H. Hass; sample 6 of $9 / 17 / 57$.

USGS 4599-SD. Penn Yan Shale Member of Genesee Formation, grayish- to brownish-black limestone containing styliolinas and other megafossils, 2.1-2.3 ft above base of Geneseo Shale Member of Genesee Formation. Collector, W. H. Hass, sample 5 of $9 / 17 / 57$.

USGS 4879-SD. Concretionary limestone lens, medium dark gray $0.15 \mathrm{ft}$ thick, in Geneseo Shale Member of Genesee Formation immediately above Leicester Marcasite Member of Moscow Formation of Sutton (1951). Collector, W. H. Hass; sample 4 of $9 / 17 / 57$.

USGS 4869-SD. Leicester Marcasite Member of Moscow Formation of Sutton (1951), 0-0.2 ft thick, yellowish-brown, poorly sorted fossiliferous sandstone with calcite and pyrite. Uneven upper and lower surfaces. Collector, W. H. Hass; sample 3 of $9 / 17 / 57$.

USGS 4870-SD. Olive-black to medium-gray calcareous shale containing abundant fossils including atrypas and spirifers; 0-0.25 ft below the Leicester Marcasite Member of Moscow Formation of Sutton (1951) in top of Windom Member of Moscow Shale. Collector, W. H. Hass; sample 1 of $9 / 17 / 57$.

USGS 4579-SD. Fossiliferous limestone 1.1-1.6 ft below top of Windom Member of Moscow Shale. Collector, W. H. Hass; sample 2 of $9 / 17 / 57$.
SECTION Ba-2-Linden (at the falls)

[Falls of Little Tonawanda Creek north of Linden, southeast rectangle of Batavia South $7 \frac{1}{2}-$ minute quadrangle]

USGS 9063-SD. Dark-gray siltstone, $0.1 \mathrm{ft}$ thick, in West River Shale Member of Genesee Formation about 20.5 ft above Genundewa Limestone Member of the Genesee. Collection made in a small side stream $100 \mathrm{ft}$ above lip of falls. Collector, W. H. Hass; sample 4 of $9 / 3 / 58$.

USGS 4560-SD. Calcareous concretion in West River Shale Member of Genesee Formation, 11-11.5 ft above base. Collector, W. H. Hass; sample 5 of $9 / 3 / 58$.

USGS 8969-SD. Calcareous bed in West River Shale Member of Genesee Formation, 2.7-3 ft above Genundewa Member. Collector, W. H. Hass; sample 1 of 5/13/59.

USGS 4558-SD. Genundewa Limestone Member of Genesee Formation, 0-0.5 ft above base (upper $0.4 \mathrm{ft}$ not collected) at lip of falls. Collector, W. H. Hass; sample 1 of $9 / 3 / 58$.

USGS 4559-SD. Limestone, $0.2 \mathrm{ft}$ thick, in Penn Yan Shale Member of Genesee Formation, 6.4-6.6 ft below top of member. Collector, W. H. Hass; sample 2 of $9 / 3 / 58$.

\section{SeCtion At-1-Elevenmile Creek}

[Creek bed and banks about $1,000 \mathrm{ft}$ north of Erie Railroad tracks and $600 \mathrm{ft}$ west of Warner Road. Warner Road is 4.2 miles east of Alden (US Highway 20), southeast rectangle of Corfu $71 / 2$-minute quadrangle, Genesee County]

USGS 4572-SD. West River Shale Member of Genesee Formation; black shale, 4.5-5 ft below Middlesex Shale Member of Sonyea Formation. Outcrop just downstream from railroad. Collector, W. H. Hass; sample 4 of $5 / 20 / 57$.

USGS 8971-SD. Medium-gray calcareous shaly siltstone, 5$5.5 \mathrm{ft}$ above base of West River Shale Member of Genesee Formation. Collector, W. H. Hass; sample 2 of 5/13/59.

USGS 4561-SD. Calcareous concretions with styliolinas and brachiopods, 3-3.5 ft above Genundewa Limestone Member of Genesee Formation, in West River Shale Member of Genesee Formation. Collector, W. H. Hass; sample 10 of $9 / 3 / 58$

USGS $4574-S D$. Top $0.2 \mathrm{ft}$ of Genundewa Limestone Member of Genesee Formation, 0.8-1 ft above base of member. Abundant styliolinas. Collector, W. H. Hass; sample 6 of $5 / 20 / 57$.

USGS 4573-SD. Concretionary limestone, 3.8-4.2 ft below Genundewa Limestone Member of Genesee Formation, in Penn Yan Shale Member of Genesee Formation. Collector, W. H. Hass; sample 5 of $5 / 20 / 57$.

USGS 8972-S.D. Same bed as USGS 4573-SD. Collector, W. H. Hass; sample 3 of $5 / 13 / 59$.

USGS 4568-SD. Brownish-black calcareous concretions and limestone containing brachiopods and stylionlinas, 2.5$2.7 \mathrm{ft}$ above base of Geneseo Shale Member of Genesee Formation. Probably, the Lodi Limestone of Clark (in Lincoln, 1895). Collector, W. H. Hass; sample 7 of $9 / 15 / 57$.

USGS 4567-SD. Pyrite zone in Geneseo Shale Member of Genesee Formation, 0.1-0.22 ft above base of member. Collector; W. H. Hass; sample 6 of $9 / 15 / 57$.

USGS 4566-SD. Leicester Marcasite Member of Moscow Formation of Sutton (1951), calcareous sandstone with pyrite, 0-0.2 ft thick, quite local. Collected at northeast end of a small falls where about $1 \mathrm{ft}^{2}$ is exposed. Collector, W. H. Hass; sample 5 of $5 / 19 / 57$. 
USGS 4565-SD. Highest concretionary limestone bed, in Windom Member of Moscow Shale, 1.1-1.6 ft below Leicester Marcasite Member of Moscow Formation of Sutton (1951). Collector, W. H. Hass; sample 4 of 9/15/57.

\section{Section Dp-3-Cayuga Creek}

[Creek bed and bluffs along Cayuga Creek near bridge on Clinton Road (N.Y. 354) and junction with Eastwood Road, about 4 miles southeast of Alden, N.Y., in northeast rectangle of East Aurora $7 \frac{1}{2}$-minute quadrangle, Erie County]

USGS 4578-SD. Genundewa Limestone Member of Genesee Formation, top $0.2 \mathrm{ft}$ of brownish-gray limestone. Collector, W. H. Hass; sample 6 of $5 / 26 / 57$.

USGS 4577-SD. Basal $0-0.4 \mathrm{ft}$ of Genundewa Limestone Member of Genesee Formation. Collector, W. H. Hass; sample 5 of $5 / 26 / 57$.

USGS 4562-SD. Penn Yan Shale Member of Genesee Formation. Limestone and zone of concretions with abundant styliolinas, $0.4 \mathrm{ft}$ thick, 7-7.4 $\mathrm{ft}$ above base of Genesee Formation. Collector, W. H. Hass; sample 1 of 9/15/57.

USGS 4576-SD. Same as USGS 4562-SD. Collector, W. H. Hass; sample 4 of $5 / 26 / 57$.

USGS 4564-SD. Limestone coquina of chonetid brachiopods, $0.03 \mathrm{ft}$ thick, in Penn Yan Shale Member of Genesee Formation just above a bed of limestone, $0.25 \mathrm{ft}$ thick, about $2.6 \mathrm{ft}$ above base of Geneseo Shale Member of Genesee Formation. Probably, the Lodi Limestone of Clarke (in Lincoln, 1895). Collector, W. H. Hass; sample 3 of $9 / 15 / 57$.

USGS 4575-SD. Limestone in Penn Yan Shale Member of Genesee Formation, 2.2-2.4 ft above contact of Genesee Formation and Moscow Shale. Collector, W. H. Hass; sample 3 of $5 / 26 / 57$.

USGS 4563-SD. Black shale containing abundant styliolinas in Geneseo Shale Member of Genesee Formation, 0.63$0.7 \mathrm{ft}$ above base of member. Collector, W. H. Hass; sample 2 of $9 / 15 / 57$.

USGS 4569-SD. Leicester Marcasite Member of Moscow Formation of Sutton (1951), 0-0.17 ft thick, calcareous and sandy at base of Geneseo Shale Member of Genesee Formation. Collector, W. H. Hass; sample 1 of 9/14/57.

USGS 4570-SD. Concretionary calcareous siltstone, in Windom Member of Moscow Shale, 0.1-0.5 ft below Genesee Formation. Collector, W. H. Hass; sample 2 of $9 / 14 / 57$.

USGS 4571-SD. Fossiliferous, calcareous siltstone, $0.1 \mathrm{ft}$ thick, and $0.5 \mathrm{ft}$ below top of Windom Member of Moscow Shale. Collector, W. H. Hass; sample 3 of 9/14/57.

\section{SeCtion Dp-1-Cazenovia Creek}

[East bank of Cazenovia Creek at bend in creek, about 4,000 ft southwat of rond junction in Spring Brook at altitude of $800 \mathrm{ft}$, central rectangle, Orchard Park $7 \%$-minute quadrangle, Erie County]

USGS 4555-SD. Calcareous siltstone, about $0.1 \mathrm{ft}$ thick, containing abundant styliolinas, $0.5 \mathrm{ft}$ below contact between Middlesex Shale Member of Sonyea Formation and West River Shale Member of Genesee Formation below. Collector, W. H. Hass; sample 8 of $8 / 31 / 58$.

USGS 4554-SD. Genundewa Limestone Member of Genesee Formation, $0.2-0.5 \mathrm{ft}$ below top of member. Collector, W. H. Hass; sample 6 of $8 / 31 / 58$.

USGS 4553-SD. Genundewa Limestone Member of Genesee Formation, 0-0.3 ft above base of member. Collector, W. H. Hass; sample 5 of $8 / 31 / 58$.
USGS 4557-SD. Genundewa Limestone Member of Genesee Formation, 0-0.2 ft above base of member. Collector, W. H. Hass; sample 3 of $8 / 8 / 52$.

USGS 4552-SD. Limestone concretion in Penn Yan Shale Member of Genesee Formation, 1.8-2.2 ft below Genundewa Limestone Member of Genesee Formation. Collector, W. H. Hass; sample 4 of $8 / 31 / 58$.

USGS 7620-SD. Leicester Marcasite Member of Moscow Formation of Sutton (1951), sandy, calcareous pyrite, 0 $0.4 \mathrm{ft}$ thick. Collector, W. H. Hass; sample 2 of $8 / 31 / 58$. USGS 4556-SD. Same as USGS 7620-SD. Collector, W. H. Hass; sample 2 of $8 / 8 / 52$.

USGS 4551-S.D. Fossiliferous limestone in Windom Member of Moscow Shale; $1.6-1.5 \mathrm{ft}$ below Leicester Marcasite Member of Moscow Formation of Sutton (1951). Collector, W. H. Hass; sample 1 of $8 / 31 / 58$.

\section{SECTion near Ed-2-Amsdell Creek}

[East bank of Amsdell Creek, behind a utility shed on east side of Amsdell Road and about $400 \mathrm{ft}$ southeast of the Conrail (old Pennsylvania Roalroad) crossing. The outcrop is about one-half mile southeast of junction of Lake Shore Road (N.Y. State Highway 5) and
Amsdell Road in Wanakah, Eden $71 / 2$-minute quadrangle, Erie County] R. R. Hibbard Collection.-University of Michigan Paleontological Museum. In 1948, R. R. Hibbard collected large samples from the "conodont bed" on Amsdell Creek, which he exchanged with some conodont workers. F. H. T. Rhodes received one of these samples from Hibbard. According to Rhodes (oral commun., 1966), the sample was argillaceous and was prepared by using sodium hydroxide. Apparently, Hibbard found a pocket of weathered North Evans Limestone of Rickard (1964) that produced beautifully preserved conodonts. I did not find weathered material, and therefore I collected limestone in place.

USGS 9439-SD. North Evans Limestone of Rickard (1964), 0.3-0.6 ft thick, brownish-gray aphanitic limestone containing streaks and pockets of crinoidal limestone and local concentrations of fish plates and phosphatic nodules. Styliolinas are abundant in the aphanitic limestone. Contact with underlying Moscow Shale is sharp. Collector, J. W. Huddle; sample 1 of $6 / 22 / 68$.

\section{Section Ed-2-Quarry at Clover Bank}

[Abandoned quarry about $1,700 \mathrm{ft}$ south of Clover Bank in northeast

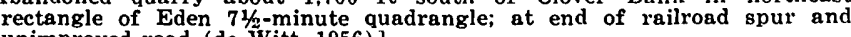
unimproved road (de Witt, 1956)]

USGS 7618-SD. North Evans Limestone of Rickard (1964), 0-0.2 ft above base. Collector, J. W. Huddle; sample 5 of $7 / 17 / 64$.

USGS 7619-SD. North Evans Limestone of Rickard (1964), 0.3-0.6 ft above base. Collector, J. W. Huddle; sample 6 of $7 / 17 / 64$

\section{SeCtion Ed-1-Eighteenmile Creek (Grabau F)}

[Creek bank at first sharp bend in creek west of (downstream) railroad bridges and 1,500 ft from railroad track in a direct northwest line. Section was described by Grabau (1898-99, sec. 3 (F), p. 22, pls. 2 and
6). North-central rectangle of Eden $7 \frac{1}{2}$-minute quadrangle (de Witt, 1956)]

USGS 4540-SD. Pyrite zone $0.05 \mathrm{ft}$ thick in West River Shale Member of Genesee Formation, $2 \mathrm{ft}$ below contact with Middlesex Shale Member of Sonyea Formation. Collector, W. H. Hass; sample 1 of $8 / 30 / 58$.

USGS 8973-SD. Brownish-gray calcareous siltstone containing styliolinas, in West River Shale Member of Genesee Formation, 0.2-0.3 ft above Genundewa Limestone Mem- 
ber of Genesee Formation. Collector, W. H. Hass; sample 5 of $5 / 14 / 59$.

USGS 4534-SD. Genundewa Limestone Member of Geneseo Formation, 0-0.25 ft below top of member. Collector, W. H. Hass; sample 6 of $9 / 13 / 57$.

USGS 4535-SD. Genundewa Limestone Member of Genesee Formation, $0.25-0.5 \mathrm{ft}$ below top of member. Collector, W. H. Hass; sample 7 of $9 / 13 / 57$.

USGS 4536-SD. Genundewa Limestone Member of Genesee Formation, basal $0.2 \mathrm{ft}$ of member. Collector, W. H. Hass; sample 8 of $9 / 13 / 57$.

USGS 4537-SD. Penn Yan Shale Member of Genesee Formation; grayish-black calcareous shale with undulating bedding, $0-0.7 \mathrm{ft}$ thick. Collector, W. H. Hass; sample 9 of $9 / 13 / 57$.

USGS 4538-SD. Leicester Marcasite Member of Moscow Formation of Sutton (1951), calcareous, pyritic sandstone, $0.05-0.2 \mathrm{ft}$ above base. Collector, W. H. Hass; sample 10 of $9 / 13 / 57$.

USGS 4539-SD. Leicester Marcasite Member of Moscow Formation of Sutton (1951), $0.05 \mathrm{ft}$ thick. Collector, W. H. Hass; sample 12 of $9 / 13 / 57$.

USGS 4541-SD. Main zone of concretions in Windom Member of Moscow Shale, $0.5-0.7 \mathrm{ft}$ below top of member. Collector, W. H. Hass; sample 3 of $8 / 30 / 58$.

\section{SeCTION Ed-1-Eighteenmile Creek (Grabau $H$ )}

["Conodont bed" of Hinde (1879), Grabau (1898-99), and Bryant (1921), the North Evans Limestone of Rickard (1964); a coarsely crystalline grayish-brown sandy limestone containing abundant fish plates and conodonts. Exposed in creekbed and northeast bank of Eighteenmile Creek just downstream from railroad bridge (Grabau, 1898-99, sec. 1 (H), p. 4, 13-16 pls, 4,5,$)$. Central rectangle of Eden $7 \frac{1}{2}$-minute quadrangle (de Witt, 1956) and 15-minute quadrangle. Bryant's (1921) ype material is from this outcrop.]

USGS 7622-SD "Conodont bed." Collector, W. H. Hass; sample 4 of $8 / 6 / 44$.

USGS 8123-SD. North Evans Limestone of Rickard (1964), "Conodont bed" of Hinde (1879), Grabau (1898-99), and Bryant (1921). Two blocks collected about $10 \mathrm{ft}$ apart and sawed into blocks and digested in acid separately. Block A was sawed into 3 blocks: A-1, the top $0.7 \mathrm{ft}$, weighing $205 \mathrm{~g}$; A-2, the middle $0.7 \mathrm{ft}, 250 \mathrm{~g}$; and A-3, the bottom $0.7 \mathrm{ft}, 336 \mathrm{~g}$. Block $\mathrm{B}$ was sawed into 4 blocks: B-1, the bottom $0.6 \mathrm{ft}, 165 \mathrm{~g}$; B-2, lower middle, $1.4 \mathrm{ft}$ thick, $331 \mathrm{~g}$; B-3, upper middle, $0.3 \mathrm{ft}$ thick, 69 g; B-4, top block, $0.5 \mathrm{ft}$ thick, $142 \mathrm{~g}$. Collector, John W. Huddle; sample 2 of $8 / 30 / 66$.

SeCtion Ed-1-Eighteenmile Creek (N.Y. State Highway 5)

[East bank of Eighteenmile Creek, $50 \mathrm{ft}$ south of east abutment of N.Y. State Highway 5 bridge over the creek. Northwest rectangle, Eden $71 / 2$-minute quadrangle, Erie County (de Witt, 1956)

USGS 4549-SD. West River Shale Member of Genesee Formation, calcareous siltstone 1.3-1.33 ft above Genundewa Limestone Member of Genesee. Collector, W. H. Hass; sample 14 of $5 / 26 / 57$.

USGS 4547-SD. Top $0.1 \mathrm{ft}$ of Genundewa Limestone Member of Genesee Formation, 0.85-0.95 ft above base. Collector, W. H. Hass; sample 12 of $5 / 26 / 57$.

USGS 4546-SD. Genundewa Limestone Member of Genesee Formation, 0.4-0.7 ft above base. Collector, W. H. Hass; sample 11 of $5 / 26 / 57$.

USGS 4545-SD. Genundewa Limestone Member of Genesee Formation, 0.1-0.4 ft above base. Collector, W. H. Hass; sample 10 of $5 / 26 / 57$.
USGS 4544-SD. Basal $0.1 \mathrm{ft}$ of Genundewa Limestone Member of Genesee Formation. Collector, W. H. Hass; sample 9 of $5 / 26 / 57$.

USGS 4548-SD. Penn Yan Shale Member of Genesee Formation, 0-0.1 ft thick. Collector, W. H. Hass; sample 13 of $5 / 26 / 57$.

USGS 4533-SD. Calcareous siltstone in Windom Member of Moscow Shale, 15-15.4 ft below Genesee Formation and 1-1.4 ft above Tichenor Limestone Member of Ludlowville Formation. Collector, W. H. Hass; sample 5 of $9 / 13 / 57$.

\section{SeCtion SC-1-Mouth of Pike Creek}

[West bank of Pike Creek at Lake Erie shore at eastern edge of Angola $71 / 2$-minute quadrangle (Silver Creek 15-minute quadrangle), Erie County. See also de Witt and Colton, 1953]

USGS 9067-SD. West River Shale Member of Genesee Formation, prominent siltstone band $0.2 \mathrm{ft}$ thick with conodonts on surfaces, 1.6-1.8 ft below Middlesex Shale Member of Sonyea Formation and 6.6-6.4 ft above Genundewa Limestone Member of Genesee Formation. Collector, W. H. Hass; sample 7 of $8 / 29 / 58$.

USGS 8974-SD. Calcareous bed, 3.2-3.3 $\mathrm{ft}$ above base of West River Shale Member of Genesee Formation along lakeshore about $300 \mathrm{ft}$ west of mouth of Pike Creek. Collector, W. H. Hass; sample 2 of 5/14/59.

USGS 8975-SD. Calcareous bed $0.25-0.27 \mathrm{ft}$ above base of West River Shale Member of Genesee Formation along lakeshore about $300 \mathrm{ft}$ west of mouth of Pike Creek. Collector, W. H. Hass; sample 4 of 5/14/59.

USGS 4525-SD. Genundewa Limestone Member of Genesee Formation, 0.7-0.9 ft above base of member. A persistent bed separated from lower part of Genundewa Limestone Member by $0.1 \mathrm{ft}$ of black shale. Collector, W. H. Hass; sample 4 of $5 / 27 / 57$.

USGS 4526-SD. Genundewa Limestone Member of Genesee Formation, $0-0.6 \mathrm{ft}$ above base of member. Limestone bed is $0.1-0.6 \mathrm{ft}$ thick. Collector, W. H. Hass; sample 3 of $5 / 27 / 57$.

USGS 4527-SD. Penn Yan Shale Member of Genesee Formation; calcareous, brownish-gray shale, $0.8 \mathrm{ft}$ thick. Numerous styliolinas. Collector, W. H. Hass; sample 2 of $5 / 27 / 57$.

USGS 4529-SD. Penn Yan Shale Member of Genesee Formation; brownish-gray calcareous shale, $0.8 \mathrm{ft}$ thick, west of mouth of Pike Creek. Collector, W. H .Hass; sample 1 of $8 / 29 / 58$.

USGS 7621-SD. Penn Yan Shale Member of Genesee Formation, at mouth of Pike Creek. Collection from $0.2-0.5 \mathrm{ft}$ above base of unit $0.7-0.9 \mathrm{ft}$ thick. Collector, W. H. Hass; sample 3 of $5 / 14 / 59$.

USGS 3984-SD. Leicester Marcasite Member of Moscow Formation of Sutton (1951). Calcareous sandy rock, 0 $0.1 \mathrm{ft}$ thick, with little pyrite at the base of the Genesee Formation. Collector, W. H. Hass; sample 1 of $5 / 27 / 57$.

USGS 4532-SD. Windom Member of Moscow Shale, 0.2-0.3 $\mathrm{ft}$ below top of member. Collector, W. H. Hass; sample 1 of $9 / 13 / 57$.

USGS 4531-SD. Nodular limestone bed in Windom Member of Moscow Shale, $0.4-0.9 \mathrm{ft}$ below top of member. Collector, W. H. Hass; sample 5 of $8 / 29 / 58$.

USGS 4530-SD. Calcareous shale bed in Windom Member of Moscow Shale with abundant ambocoelias just below coral bed of Grabau (1898-99, p. 29-30, 47-48), 8.7-8.9 
ft below top of member. Collector, W. H. Hass; sample 4 of $8 / 29 / 58$.

\section{REFERENCES CITED}

Adrichem Boogaert, H. A. van, 1967, Devonian and Lower Carboniferous conodonts of the Cantabrian Mountains (Spain) and their stratigraphic application: Leidse Geol. Meded., v. 39, p. 129-199.

Anderson, W. I., 1966, Upper Devonian conodonts and the Devonian-Mississippian boundary in north-central Iowa: Jour. Paleontology, v. 40, no. 2, p. 395-415.

Bartenstein, Helmut, and Bischoff, Gunter., 1962, ConodontenStratigraphie im Devon und Unterkarbon Deutschland, in Simon, W., and Bartenstein, H., Leitfossilen der Micropalaontologie: Berlin, Gebrüder Borntraeger, p. 43-66.

Bassler, R. S., 1925, Classification and stratigraphic use of conodonts [abs.]: Geol. Soc. America Bull., v. 36, no. 1, p. 218-220.

Beckmann, Heinz, 1949, Conodonten aus dem Iberger Kalk (Ober-Devon) des Bergischen Landes und ihr Feinbau: Senckenbergiana, v. 30, p. 153-168.

Bergström, S. M., 1964, Remarks on some Ordovician conodont faunas from Wales: Lund Univ. Acta, sec. 2, no. 3, p. 1-67.

Bergström, S. M., and Sweet, W. C., 1966, Conodonts from the Lexington Limestone (Middle Ordovician) of Kentucky and its lateral equivalents in Ohio and Indiana: Bulls. Am. Paleontology, v. 50, no. 229, p. 271-441.

Bischoff, Gunther, 1956, Oberdevonische Conodonten (to1 $\delta$ ) aus dem Rheinischen Schiefergebirge: Hesse Landesamt. Bodenforschung Notizbl., v. 84, p. 115-137.

Bischoff, Gunther, and Ziegler, Willi, 1956, Das Alter der "Urfer Schichten" in Marburger Hinterland nach Conodonten: Hesse Landesamt. Bodenforschung Notizbl., v. 84, p. 138-169.

- 1957, Die Conodontenchronologie des Mitteldevons und des tiefsten Oberdevons: Hesse Landesamt. Bodenforschung Abh., v. 22, $136 \mathrm{p}$.

Borden, W. W., 1876, Jennings and Ripley Counties: Indiana Geol. Survey 7th Ann. Rept., p. 146-202.

Bouckaert, J., and Streel, M., eds., 1974, Guidebook, International symposium on Belgian micropaleontological limits, Namur 1974: Belgian Adm. Mines-Geol. Survey.

Branson, E. B., 1920, A geologic section from 40 miles west of St. Louis to Jackson County, Missouri: Am. Jour. Sci., 4th ser., v. 49, p. 267-278.

1944, The geology of Missouri: Missouri Univ. Studies, v. 19 , no. $3,535 \mathrm{p}$.

Branson, E. B., and Mehl, M. G., 1933, A study of Hinde's types of conodonts preserved in the British Museum: Missouri Univ. Studies, v. 8, no. 2, p. 77-167.

- 1934a, Conodonts from the Grassy Creek shale of Missouri: Missouri Univ. Studies, v. 8, no. 3, p. 171259.

1934b, Conodonts from the Bushberg sandstone and equivalent formations of Missouri: Missouri Univ. Studies, v. 8 , no. 4 , p. $265-299$.

1938, The conodont genus Icriodus and its stratigraphic distribution: Jour. Paleontology, v. 12, no. 2, p. 156-166.
- 1940, Caney conodonts of Upper Mississippian age: Denison Univ. Sci. Lab. Jour., v. 35, art. 5, p. 167-181 [1941]

1941, New and little known Carboniferous conodont genera: Jour. Paleontology, v. 15, no. 2, p. 97-106.

- 1944, Conodonts, p. 235-246, Pl. 93, 94, IN, Shimer, H. W., and Shrock, R. R., Index fossils of North America: The M. I. T. Press, Cambridge, 837 p.

Branson, E. R., 1933, Conodonts from the Hannibal formation of Missouri: Missouri Univ. Studies, v. 8, no. 4, p. $301-343$.

Bryant, W. L., 1921, The Genesee conodonts: Buffalo Soc. Nat. Sci. Bull., v. 13, no. 2, 59 p.

Bultynck, P., 1970, Revision stratigraphique et paléontologique de la coupe type du Couvinien: Louvain Univ. Inst. Geol. Mém., v. 26, 152 p.

1972, Middle Devonian Icriodus assemblages (Conodonta) : Geologica et Palaeontologica, v. 6, p. 71-86.

Caster, K. E., 1933, Upper Devonian rocks at Ithaca, New York [abs.]: Geol. Soc. America Bull., v. 44, no. 1, p. 201-202.

Clark, D. L. (ed.), 1971, Conodonts and biostratigraphy of the Wisconsin Paleozoic: Wisconsin Geol. and Nat. History Survey Inf. Circ. 19, $151 \mathrm{p}$.

Clark, D. L., and Ethington, R. L., 1966, Conodonts and biostratigraphy of the Lower and Middle Devonian of $\mathrm{Ne}$ vada and Utah: Jour. Paleontology, v. 40, no. 3, p. 659689.

1967, Conodonts and zonation of the Upper Devonian in the Great Basin: Geol. Soc. America Mem. 103, $94 \mathrm{p}$.

Clarke, J. M., and Luther, D. D., 1905, Geology of the Watkins and Elmira quadrangles [N.Y.]: New York State Mus. Bull. 81, p. 3-29.

Coen, M., 1972, Facies, conodontes et stratigraphie du Frasnien de l'est de la Belgique pour servir a une revision de l'étage: Soc. Géol. Belgique Ann., v. 95 (1972), no. 2, p. 239-252, [1973].

Cooper, C. L., 1931, New conodonts from the Woodford formation of Oklahoma: Jour. Paleontology, v. 5, no. 3, p. 230-243.

- 1939, Conodonts from a Bushberg-Hannibal horizon in Oklahoma: Jour. Paleontology, v. 13, no. 4, p. 379-422.

Cooper, C. L., and Sloss, L. L., 1943, Conodont fauna and distribution of a Lower Mississippian black shale in Montana and Alberta: Jour. Paleontology, v. 17, no. 2, p. 168-176.

Cooper, G. A., 1930, Stratigraphy of the Hamilton group of New York: Am. Jour. Sci., 5th ser., v. 19, no. 110, p. 116134 ; no. 111, p. 214-236.

Cooper, G. A., and Williams, J. S., 1935, Tully formation of New York: Geol. Soc. America Bull., v. 46, no. 5, p. 781868.

Davis, W. E., Jr., 1966, Conodont fauna of the Tully Limestone, Middle Devonian, New York State: Boston, Mass., Boston Univ., unpub. Ph.D. thesis. (Ann Arbor, Mich., University Microfilms, Inc., no. 66-11, 339 p.)

de Witt, Wallace, Jr., 1956, Bedrock geology of the Eden quadrangle, New York: U.S. Geol. Survey Geol. Quad. Map GQ-96.

de Witt, Wallace, Jr., and Colton, G. W., 1953, Bedrock geology of the Silver Creek quadrangle, New York: U.S. Geol. Survey Quad. Map GQ-30. 
1959, Revised correlations of lower Upper Devonian rocks in western and central New York: Am. Assoc. Petroleum Geologists Bull., v. 43, no. 12, p. 2810-2828.

1979, Physical stratigraphy of the Genesee Formation (Devonian) in western and central New York: U.S. Geol. Survey Prof. Paper 1032-A, 22 p.

Druce, E. C., 1969, Devonian and Carboniferous conodonts from the Bonaparte Gulf Basin, Northern Australia: Australia Bur. Mineral Resources, Geology and Geophysics Bull. 98, 243 p.

Durdanović, Zarko, 1968, Konodonte Donjeg Devona I Donjeg Karbona Zapadno od Dvora na uni (Hrvatska-Jugoslavija) : Geoloski Vjesnik Inst., Zagreb, v. 21, p. 93-104.

Ethington, R. L., 1965, Late Devonian and Early Mississippian conodonts from Arizona and New Mexico: Jour. Paleontology, v. 39 , no. 4 , p. 566-589.

Ethington, R. L., and Furnish, W. M., 1962, Silurian and Devonian conodonts from Spanish Sahara: Jour. Paleontology, v. 36, no. 6, p. 1253-1290.

Flajs, G., 1966, Die Mitteldevon/Oberdevon-Grenze in Paläozoikum von Graz: Neues Jahrb. Geologie Paläontologie Abh. 124, p. 221-240.

Fraunfelter, G. H., 1965, The paleontology and stratigraphy of the Cedar City formation (Middle Devonian) of Missouri [abs.]: Dissert. Abs., v. 25, no. 7, p. 4079.

Freyer, Günter, 1961, Zur Taxionomie und Biostratigraphie der Conodonten aus dem Oberdevon des Vogtlandes unter besonderer Berucksichtigung des to V/VI: Freiberger Forschungshefte, C-95, p. 1-96.

Glenister, B. F., and Klapper, Gilbert, 1966, Upper Devonian conodonts from the Canning Basin, Western Australia: Jour. Paleontology, v. 40, p. 777-842.

Grabau, A. W., 1898-1899, Geology and paleontology of Eighteen Mile Creek and the lake shore sections of Erie County, New York: Buffalo Soc. Nat. Sci. Bull., v. 6, $403 \mathrm{p}$.

Grossman, W. L., 1944, Stratigraphy of the Genesee group of New York: Geol. Soc. America Bull., v. 55, no. 1, p. 41-76.

Gunnell, F. H., 1933, Conodonts and fish remains from the Cherokee, Kansas City, and Wabaunsee groups of Missouri and Kansas: Jour. Paleontology, v. 7, no. 3, p. 261-297.

Hass, W. H., 1956, Age and correlation of the Chattanooga shale and the Maury formation: U.S. Geol. Survey Prof. Paper 286, 47 p.; abs. in Geol. Soc. America Bull., v. 64, p. 1532.

1958, Upper Devonian conodonts of New York, Pennsylvania, and interior states: Jour. Paleontology, v. 32, no. 4 , p. 765-769.

1959, Conodont faunas from the Devonian of New York and Pennsylvania [abs.]: Geol. Soc. America Bull., v. 70 , no. 12 , pt. 2, p. 1615 .

1962, Conodonts, in Moore, R. C., ed., Treatise on invertebrate paleontology, $\mathrm{Pt}$. W, Miscellanea: New York and Lawrence, Kan., Geol. Soc. America and Univ. Kansas Press, p. W3-W69.

Heckel, P. H., 1973, Nature, origin, and significance of the Tully Limestone: Geol. Soc. America Spec. Paper 138, $244 \mathrm{p}$.

Helms, J., 1959, Conodonten aus dem Saalfelder-Oberdevon (Thuringen) : Geologie, Jahrg. 8, p. 634-677.
Hinde, G. J., 1879, On conodonts from the Chazy and Cincinnati group of the Cambro-Silurian and from the Hamilton and Genesee shale divisions of the Devonian in Canada and the United States: Geol. Soc. London Quart. Jour., v. 35, pt. 3, p. 351-369.

Holmes, G. B., 1928, A bibliography of the conodonts with descriptions of early Mississippian species: U.S. Natl. Mus. Proc., v. 72, art. 5, 38 p.

House, M. R., 1962, Observations on the ammonoid succession of the North American Devonian: Jour. Paleontology, v. 36, no. 2, p. 247-284.

- 1965, A study in the Tornoceratidae-the succession of Tornoceras and related genera in the North American Devonian: Royal Soc. London Philos. Trans., ser. B, v. 250, p. $79-130$.

- 1966, Goniatite zonation of the New York State Devonian, in Buehler, E. J., ed., New York State Geol. Assoc., Guidebook, 38th Ann. Mtg., Western New York, 1966: p. 53-57.

1967, Devonian ammonoid zonation and correlations between North America and Europe, in Internat. Symposium on the Devonian System, Calgary, Alberta, 1967, v. 2: Calgary, Alberta Soc. Petroleum Geologists, p. 1061-1068 [1968].

- 1973, Delimitation of the Frasnian: Acta Geol. Polonica, v. 23, no. 1, p. 1-14.

Huddle, J. W., 1934, Conodonts from the New Albany shale of Indiana: Bulls. Am. Paleontology, v. 21, no. 72, p. 1136.

- 1968, Redescription of Upper Devonian conodont genera and species proposed by Ulrich and Bassler in 1926: U.S. Geol. Survey Prof. Paper 578, 55 p.

- 1970, Revised descriptions of some late Devonian polygnathid conodonts: Jour. Paleontology, v. 44, no. 6, p. 1029-1040.

- 1972, Historical introduction to the problem of conodont taxonomy, in Symposium on conodont taxonomy, Marburg 1972: Geologica et Palaeontologica, Sonderband 1, p. 3-16.

Jeppsson, Lennart, 1969, Notes on some Upper Silurian multielement conodonts: Geol. Fören. Stockholm Förhandl., v. 91, p. 12-24.

1971, Element arrangement in conodont apparatuses of Hindeodella type and in similar forms: Lethaia, v. 4, no. 1, p. 101-123.

Khalymbadzha, V. G., and Chernysheva, N. G., 1970, [Conodonts of the genus Ancyrodella from Devonian deposits of the Volga-Kama region and their stratigraphic significance], in Biostratigraphiya and paleontologiya Paleozoyskikh otlozheniy vostoka Russkoy [western transUral] platformy i zapadnogo priural'ya: Kazan. Gos. Univ., v. 1, p. 81-103 (in Russian).

Kirchgasser, W. T., 1970, Conodonts from near the middle/ upper Devonian boundary in north Cornwall: Palaeontology, v. 13 , pt. 3 , p. 335-354.

1974, Stratigraphic sequence of the ammonoid Probeloceras Clarke in the Upper Devonian of the Appalachian Basin [abs.]: Geol. Soc. America Abs. with Programs, v. 6, no. 1, p. 44-45.

Klapper, Gilbert, 1966, Upper Devonian and Lower Missippian conodont zones in Montana, Wyoming, and South Dakota: Kansas Univ. Paleont. Contr. Paper 3, 43 p. 
1971, Sequence within the conodont genus Polygnathus in New York lower Middle Devonian: Geologica et Palaeontologica, v. 5, p. 59-79.

Klapper, Gilbert, and Philip, G. M., 1971, Devonian conodont apparatuses and their vicarious skeletal elements: Lethaia, v. 4 , no. 4 , p. $429-452$.

- 1972, Familial classification of reconstructed Devonian conodont apparatuses: Geologica et Palaeontologica, Sonderband 1, p. 97-114.

Klapper, Gilbert, Philip, G. M., and Jackson, J. H., 1970, Revision of the Polygnathus varcus group (Conodonta, middle Devonian): Neues Jahrb. Geologie u. Paläontologie Monatsh., no. 11, p. 650-667.

Klapper, Gilbert, Sandberg, C. A., Collinson, C. W., Huddle, J. W., Orr, R. W., Rickard, L. V., Schumacher, Dietmar, Seddon, George, and Uyeno, T. T., 1971, North American Devonian conodont biostratigraphy, in Sweet, W. C., and Bergström, S. M., eds., Symposium on conodont biostratigraphy: Geol. Soc. America Mem. 127, p. 285-316.

Klapper, Gilbert, and Ziegler, Willi, 1967, Evolutionary development of Icriodus latericrescens group (Conodonta) in the Devonian of Europe and North America: Paläontographica, v. 127, Abt. A., p. 68-83.

Krebs, Wolfgang, 1959, Zur Grenze Mittel-/Ober-Devon und zur Gliederung des obersten Mittel-Devons und der tieferen Adorf-Stufe nach Conodonten: Senckenbergiana Lethaea, v. 40, p. 367-387.

Kullmann, Jürgen, and Ziegler, Willi, 1970, Conodonten und Goniatiten von der Grenze Mittel/Oberdevon aus dem Profil am Martenberg (Ostrand des Rheinischen Schiefergebirges): Geologica et Palaeontologica, v. 4, p. 7385.

Lincoln, D. F., 1895, Report on the structural and economic geology of Seneca County [N.Y.] : New York State Geologist Ann. Rept. 14, p. 57-125 [1897]; New York State Mus. Ann. Rept. 48, v. 2, p. 57-125 [1897].

Lindström, Maurits, 1964, Conodonts: Amsterdam, Elsevier Pub. Co., p. 1-196.

1968, Toward a taxonomy of the conodont animal [abs.]: Geol. Soc. America, North-Central sec., 1968 Ann. Mtg., Iowa City, Iowa, Program, p. 46.

Lindström, Maurits, and Ziegler, Willi, 1972, eds., Symposium on conodont taxonomy: Geologica et Palaeontologica, Sonderband 1, $158 \mathrm{p}$.

Lineback, Jerry A., 1968, Subdivisions and depositional environments of New Albany Shale (Devonian-Mississippian) in Indiana: Am. Assoc. Petroleum Geologists Bull., v. 52 , no. 7 , p. 1291-1303.

1970, Stratigraphy of the New Albany Shale in Indiana: Indiana Geol. Survey Bull. 44, $73 \mathrm{p}$.

Lys, Maurice, Serre, Bernedette, and Deroo, G., 1957, Etudes micropaléontologiques dans le paléozoïque de la Montagne Noire: Inst. Français Petrole Rev., v. 12 , no. $7-8$, p. 783-809.

Mayr, U., 1968, Subdivisions and correlations of the Tully Formation (Upper Devonian) in New York State and Pennsylvania on the basis of statistical analysis of selected conodonts [abs.]: Bull. Canadian Petroleum Geology, v. 16, no. 3, p. 421 .

Mehl, M. G., 1960, The relationships of the base of the Mississippian System in Missouri: Denison Univ. Sci. Lab. Jour., v. 45, art. 5, p. 57-107.
Mehl, M. G., and Ziegler, Willi, 1962, A neotype for Palmatolepis gracilis Branson and Mehl 1934: Denison Univ. Sci. Lab. Jour., v. 45, art. 14, p. 197-207 [1963].

Miller, A. K., and Youngquist, W. L., 1947, Conodonts from the type section of the Sweetland Creek shale in Iowa: Jour. Paleontology, v. 21, no. 6, p. 501-517.

Moore, R. C., 1928, Early Mississippian formations in Missouri: Missouri Bur. Geology and Mines, v. 21, 2d ser., $283 \mathrm{p}$.

Mosher, L. C., and Clark, D. L., 1965, Middle Triassic conodonts from the Prida Formation of northwestern Nevada: Jour. Paleontology, v. 39, p. 551-565.

Mound, M. C., 1968, Upper Devonian conodonts from southern Alberta: Jour. Paleontology, v. 42, p. 444-524.

Mouravieff, A. N., and Bouckaert, Joseph, 1973, Mallieux's (1940), Manticoceras intumescens (Beyrich) in the Belgian Frasnian with respect to the conodont zonations: Geologica et Palaeontologica, v. 7, p. 93-95.

Müller, K. J., 1956, Triassic conodonts from Nevada: Jour. Paleontology, v. 30 , no. 4 , p. $818-830$.

Müller, K. J., and Clark, D. L., 1967, Early Late Devonian conodonts from the Squaw Bay Limestone in Michigan: Jour. Paleontology, v. 41, no. 4, p. 902-919.

Müller, K. J., and Müller, E. M., 1957, Early Upper Devonian (Independence) conodonts from Iowa, Pt. 1: Jour. Paleontology, v. 31, no. 6, p. 1069-1108.

Norris, A. W., and Uyeno, T. T., 1972, Stratigraphy and conodont faunas of Devonian outcrop belts, Manitoba: Geol. Assoc. Canada Spec. Paper 9, p. 209-223.

Oliver, W. A., Jr., de Witt, Wallace, Jr., Dennison, J. M., Hoskins, D. M., and Huddle, J. W., 1969, Correlation of Devonian rock units in the Appalachian Basin: U.S. Geol. Survey Oil and Gas Inv. Chart OC-64.

Olivieri, R., 1965, L'aspetto della fauna a conodonti nel Devoniano Superiore del Gerrei (Sardegna): Soc. Paleontologica Italiana Bull., v. 4, no. 1, 37 p.

1969, Conodonti e zonatura del Devoniano Superiore e riconoscimento di Carbonifero Inferiore nei calcari di corona mizziu (Gerrei-Sardegna): Soc. Paleontologia Italiana Bull., v. 8, no. 2, 90 p.

Orr, R. W., 1964, Conodonts from the Devonian Lingle and Alto Formations of southern Illinois: Illinois State Geol. Survey Circ. 361, 28 p.

1971, Conodonts from Middle Devonian strata of the Michigan Basin: Indiana Geol. Survey Bull. 45, $110 \mathrm{p}$.

Orr, R. W., and Klapper, Gilbert, 1968, Two new conodont species from the Middle-Upper Devonian boundary beds of Indiana and New York: Jour. Paleontology, v. 42, no. 4 , p. 1066-1075.

Panseri, C., and Barsotti, G., 1959, Conodontos y Ostracodos Devonianos de la region de Semara (Sahara Español): España Inst. Geol. y Minero Notas y Commun., no. 55, p. 145-176.

Philip, G. M., 1965, Lower Devonian conodonts from the Tyers area, Gippsland, Victoria: Royal Soc. Victoria Proc., v. 79, p. 95-115.

1966, Middle Devonian conodonts from the Moore Creek Limestone, northern New South Wales: Royal Soc. New South Wales Jour. and Proc., v. 100, p. 151-161, [1967].

Pohl, E. R., 1929, The Devonian of Wisconsin; Pt. I, Lamellibranchiata: Milwaukee Public Mus. Bull., v. 11, no. 1, p. 1-100. 
Pollock, C. A., 1968, Lower Upper Devonian conodonts from Alberta, Canada: Jour. Paleontology, v. 42, no. 2, p. 415-443.

Pölsler, Peter, 1969, Conodonten aus dem Devon der Karnischen Alpen (Findenigkofel, Ósterreich): [Austria] Geol. Bundesanst. Jahrb., v. 112, no. 2, p. 399-440.

Rhodes, F. H. T., Austin, R. L., and Druce, E. C., 1969, British Avonian (Carboniferous) conodont faunas, and their value in local and intercontinental correlation: British Mus. (Nat. History) Bull., Geology, Supp. 5, $313 \mathrm{p}$.

Rhodes, F. H. T., and Dineley, D. L., 1957, Devonian conodont faunas from southwest England: Jour. Paleontology, v. 31, p. $353-369$.

Rhodes, F. H. T., and Müller, K. J., 1956, The conodont genus Prioniodus and related forms: Jour. Paleontology, v. 30 , p. $695-699$.

Rickard, L. V., 1964, Correlation of the Devonian rocks in New York State: New York State Mus, and Sci. Service Geol. Survey Map and Chart ser., no. 4.

Sannemann, D., 1955, Oberdevonische Conodonten: Senckenbergiana Lethaea, v. 36, p. 123-156.

Schönlaub, Hans Peter, 1969, Das Paläozoikum zwischen Bischofalm und Hohem Trieb (Zentrale Karnische Alpen) : [Austria] Geol. Bundesanst. Jahrb., v. 112, no. 2, p. 265320.

Schopf, T. J. M., 1966, Conodonts of the Trenton Group (Ordovician) in New York, southern Ontario, and Quebec: New York State Mus. and Sci. Service Bull. 405, $105 \mathrm{p}$.

Schulze, Rudolf, 1968, Die conodonten aus dem Paläozoikum der mittlern Karawanken (Seeberggebiet) : Neues Jahrb. Geologie u. Paläontologie Abh., v. 130, no. 2, p. 133-245.

Scott, A. J., and Collinson, C. W., 1961, Conodont faunas from the Louisiana and McCraney formations of Illinois, Iowa, and Missouri, in Kansas Geol. Soc., Ann. Field Conf., 26th, Guidebook: p. 110-142.

Seddon, George, 1969, Conodont and fish remains from the Gneudna Formation, Carnarvon basin, Western Australia: Royal Soc. Western Australia Jour., v. 52, pt. 1, p. 21-30.

1970, Pre-Chappel conodonts of the Llano region, Texas: Texas Univ. Bur. Econ Geology Rept. Inv, 68, $130 \mathrm{p}$.

Shaffer, B., 1963, A unique ontogeny in some polygnathid conodonts: Compass, v. 41, no. 1, p. 14-19.

Shimer, H. W., and Shrock, R. R., 1944, Index fossils of North America: New York, John Wiley \& Sons, 837 p.

Spasov, Khr., 1964, Beitrag zur stratigraphie des Silurs und Devons im Kraiste: Bulgarian Geol. Soc. Rev., v. 25, pt. 3, p. 267-283.

Spasov, Khr., and Stevanovic, Peter, 1962, Oberdevonische Conodonten aus Druzetic in westlichen Serbien [in Russian]: Annales Géol. Peninsula Balkanique, v. 29, p. $53-65$.

Stauffer, C. R., 1938, Conodonts of the Olentangy shale: Jour. Paleontology, v. 12 , no. 5, p. 411-443.

1940, Conodonts from the Devonian and associated clays of Minnesota: Jour. Paleontology, v. 14, p. 417435.

Stewart, G. A., and Sweet, W. C., 1956, Conodonts from the Middle Devonian bone beds of central and west-central Ohio: Jour. Paleontology, v. 30, no. 2, p. 261-273.
Sutton, R. G., 1951, Stratigraphy and structure of the Batavia quadrangle [N.Y.]: Rochester Acad. Sci. Proc., v. 9, nos. 5-6, p. 348-408.

Sweet, W. C., and Bergström, S. M., 1972, Multielement taxonomy and Ordovician conodonts: Geologica et Palaeontologica, Sonderband 1, p. 29-42.

Szulczewski, Michal, 1971, Upper Devonian conodonts, stratigraphy and facial development in the Holy Cross Mountains: Acta Geol. Polonica, v. 21, no. 1, p. 1-129.

Thomas, L. A., 1949, Devonian-Mississippian formations of southeast Iowa: Geol. Soc. America Bull., v. 60, no. 4, p. 403-407.

Torrey, P. D., and others, 1932, The geology of New York and northern Pennsylvania: Am. Petroleum Inst., Div. Production, Paper 826-4A, 19 p.

Ulrich, E. O., and Bassler, R. S., 1926, A classification of the toothlike fossils, conodonts, with description of American Devonian and Mississippian species: U.S. Natl. Mus. Proc., v. 68, art. 12, p. 1-63. (Abs., 1925, Geol. Soc. America Bull., v. 36 , p. 218-220.)

Uyeno, T. T., 1967, Conodont zonation, Waterways Formation (Upper Devonian), northeastern and central Alberta: Canada Geol. Survey Paper 67-30, 21 p.

1974, Conodonts of the Waterways Formation (Upper Devonian) of northwestern and central Alberta: Canada Geol. Survey Bull. 232, 93 p.

Walliser, O. H., 1962, Conodontenchronologie des Silurs (=Gotlandiums) und des tieferen Devons mit besonderer Berücksichtigung der Formationsgrenze: Symposium Silur/Devon-Grenze, Bonn-Bruxelles 1960, p. 281-287.

1964, Conodonten des Silurs: Hesse Landesamt Bodenforschung Abh., v. 41, p. 1-106.

Webers, G. F., 1966, The Middle and Upper Ordovician conodont faunas of Minnesota: Minnesota Geol. Survey Spec. Pub. 4, 123 p.

Wirth, Michael, 1967, Zur gliederung des höheren Paläozoikums (Givet-Namur) im Gebiet des Quinto Real (Westpyrenäen mit Hilfe von Conodonten): Neues Jahrb., Geologie u. Paläontologie Abh., v. 127, no. 2, p. 179-244.

Wittekindt, Hanspeter, 1965, Zur Conodontenchronologie Des Mitteldevons: Fortschr. Geologie Rheinland u. Westfalen, v. 9, p. 621-646 [1966].

Wolska, Zdzislawa, 1967, Upper Devonian conodonts from the south-west region of the Holy Cross Mountains, Poland: Acta Palaeontologica Polonica, v. 12, no. 4, p. 363-456.

Youngquist, W. L., 1945, Upper Devonian conodonts from the Independence shale(?) of Iowa: Jour. Paleontology, v. 19, no. 4 , p. 355-367.

- 1947, A new Upper Devonian conodont fauna from Iowa: Jour. Paleontology, v. 21, no. 2, p. 95-112.

Youngquist, W. L., Hibbard, R. R., and Reimann, I. G., 1948, Additions to the Devonian conodont faunas of western New York: Jour. Paleontology, v. 22, no. 1, p. 48-59.

Youngquist, W. L., and Miller, A. K., 1948, Additional conodonts from the Sweetland Creek shale of Iowa: Jour. Paleontology, v. 22, no. 2, p. 440-450.

Ziegler, Willi, 1958, Conodontenfeinstratigraphische Untersuchungen an der Grenze Mitteldevon/Oberdevon und in der Adorfstufe: Hesse Landesamt Bodenforschung, Notizbl., v. 87 , p. 7-77. 
1962, Taxionomie und Phylogenie Oberdevonischer Conodonten und ihre stratigraphische Bedeutung: Hesse Landesamt Bodenforschung Abh., v. 38, 166 p.

1965a, Zum höchsten Mitteldevon an der Nordflanke des Ebbsattels: Fortschr. Geologie Rheinland u. Westfalen, v. 9, p. 519-538 [1966].

1965b, Eine Verfeinerung der Conodontengliederung an der Grenze Mittel/Oberdevon: Fortschr. Geologie Rheinland u. Westfalen, v. 9, p. 647-676 [1966].

1971, Conodont stratigraphy of the European Devo- nian, in Sweet, W. C., and Bergström, S. M., eds., Symposium on conodont biostratigraphy: Geol. Soc. America Mem. 127, p. 227-284.

ed., 1975, Catalogue of conodonts: Stuttgart, E. Schweizerbart'sche Verlagsbuchhandlung (Nägele u. Obermiller), v. 3, $403 \mathrm{p}$.

Ziegler, Willi, Klapper, Gilbert, and Lindström, Maurits, 1964, The validity of the name Polygnathus (Conodonta, Devonian and Lower Carboniferous): Jour. Paleontology, v. 38 , no. 2, p. $421-423$. 



\section{INDEX}

[Italic page, numbers indicate major references]

A

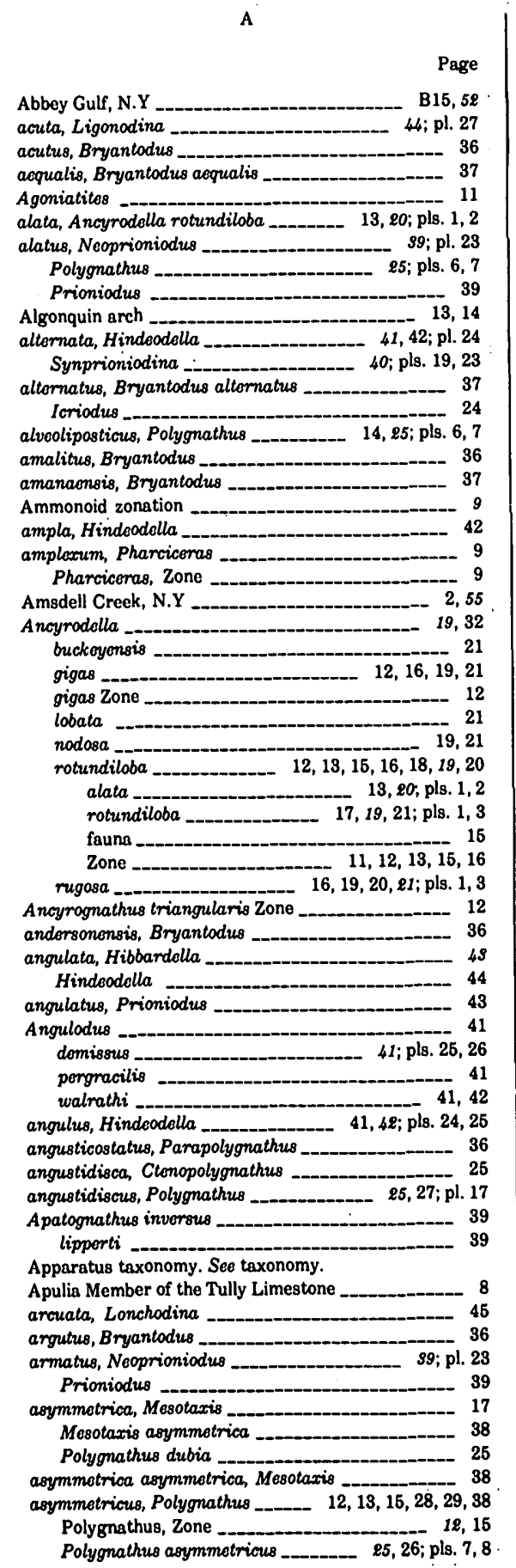

Page

asymmetricus asymmetricus,

Polygnathus _-_________ 265, 26;s. 7, 8

asymmetricus ovalis, Palmatolepis

Polygnathus ____ 12, 26, 30; pls. 7, 8, 14, 16 asymmetricus unilabius, Polygnathus _._ 1, 26; pls. 7, 8 attentuatus, Bryantodus ______ 35 aurita, Diplododella aurita, Diplododella aversa, Prioniodina _._._._. 34 aversus, Bryantodus _-_-_-_-_-_- $34,44,46 ;$ pls. 29, 30

Babbitt Corner, N:Y

Beards Creek, N.Y

beckmanni, Polygnathus

Beechwood Limestone Member of the

Sellersburg Limestone (Indiana) ______________ 12

bellatulus, Bryantodus _.__________________ 36

Bellona, N.Y _-_ 14, 15, 50

Bethany Center, N.Y _-___________ 18,

bezoensis, Bryantodus 46

Bibliography

bicornis, Bryantodus _- 37

bicristatus, Bryantodus _-_ 37

biculminatus, Bryantodus _____ 34,45

Big Stream, N.Y

bilateralis, Diplododella _.___-_ 43

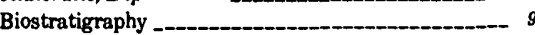

Blade elements _-

blanda, Trichognathus _- 43 Trichonodella ___ 4s, 46; pls. 29, 30 Trichonodella
brachyodontus, Bryantodus _.___- 4s, 46; pls. 29,30 brevilamina, Polygnathus _-______-_ 27 brevilaminus, Polygnathus ________ 27; pl. 17

brevis, Ieriodus _ 22 Spathognathodus _-_ 11, 13 Bristol Center, N.Y bryanti, Bryantodus _- 36 Polygnathus _.

Bryantodus 34 . acutus - 36 acutus - aequalis alternatus _-_-_-_-_-_-_-_-_-_-_-_-_-_ 37 amalitus _-_-_-_-_-_-_-_-_-_-_-_-_ 36 amanaconsis andersonensis -_- 36

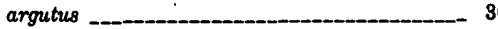
attentuatus _-.._- 35 ausablensis _________________ 36 aversus __________ $34,44,46$; pls. 29, 30 bellatulus ___ 36 bezoensis _- 46 bicornis _________ 37

bicristatus _- 37 biculminatus 34,45 brachyodontus _-________________ 37 bryanti _-_________ 36 chesteri _-_ 37 coalescenoides _...___ 35 cognatus - 39 colligatus ____ 16, 34, 95,37 ; pls. 22, 26

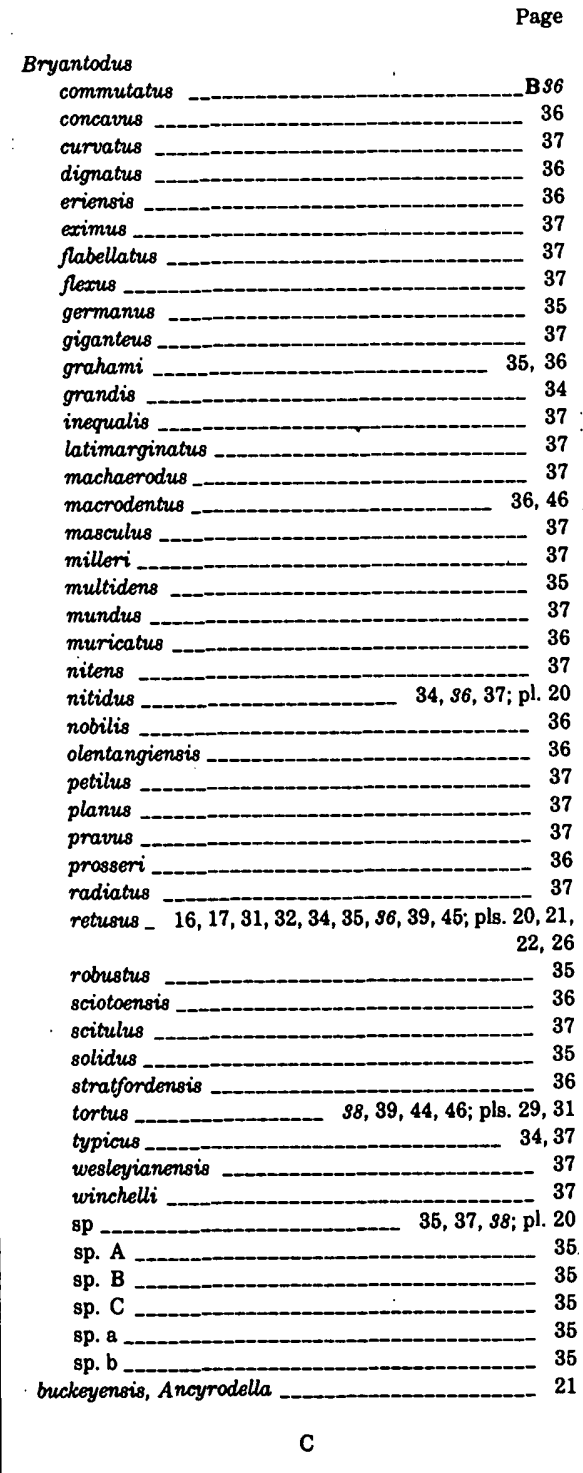

caelatus, Polygnathus _....... 13, 27, 28; pls. 11, 12, 13 Carpenter Falls bed of the Lower Member of the

Tully Limestone
Cashaqua Shale Member of the Sonyea Formation _-_ cataphractum, Manticoceras, Zone

Cayüa Creek, N. $\bar{Y}$.

$13,15,55$

Cayuga Lake, N.Y ___ 13, 14,

Cazenovia Creek, N.Y _____ 15,

Cedar Valley Limestone (Iowa) _._-_____-_-_ 12

Cedar Valley Limestone (Missouri) _.__________ 12

Cedar Valley Limestone, Rapid. Member of _...____ 12 Solon Member of 


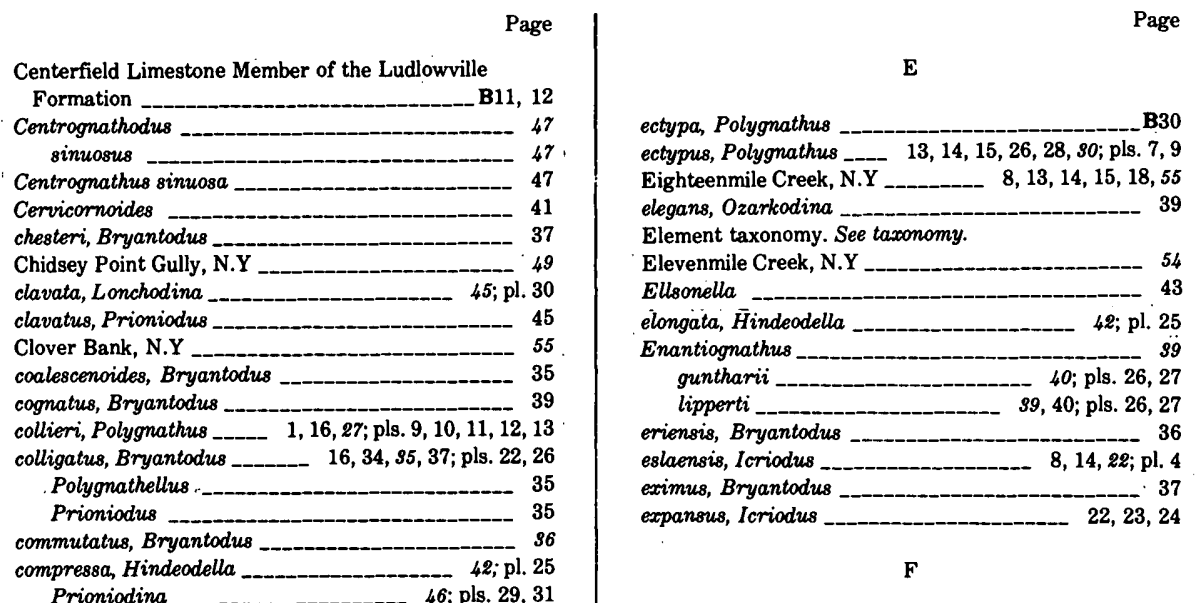

concavrus, Bryantodive

confertissima, Diplododello

Hibbardella

congesto Ozarkodina

Conodont a

"Conodont bed"

Conodont zonation

1,9

appearances in the Geness Formation

cooperi, Lonchodina

Polygmathus linguiformis

cordatum, Manticaceras, Zone

Corry Gully, N.Y

Coy Glen, N.Y

cristata, Polygnathus _-____ 26,30

cristatus, Polygnathus _..__. 12, 13, 16, 28, 34; pls. 9, 10

Polygnathus, Zone

Priomiodus

cristatus sensu, Polygnathus _-_-_-_-_-_- 26

Crickites holzapfeli Zone

Crosby Sandstone Member of the Standish

Formation 3, 15, 16

Ctenognathus (Pandorinellina) insita

Ctenopolygnathus angustidisca _.._-_-_-_-_-_-_ 25 curvatis, Bryantodus

Polynathellus

curvirastratus, Icriodus nodosus

cymbiformis, Icriodus

\section{D}

decorosus, Polygnathus

deformis, Polygnathus

Delotaxis

41; pls. 25, 26 $13,15,26,29,34 ;$ pl. 6 Dewey Hill, N.Y
dialata, Prioniodina 52 dialatus, Prioniodus

dignatus, Bryantodus

Dinodus

43

Diplododella

aurita

bilateralis

confertissima

disparalvea Palmatolepis $13,15,25, \mathrm{pl} 6$

dubia Polygmathus

Polygnathus dubia

dubia asymmetrica, Polygnathus
dubia, Polygnathus

dubius, Polygnathus ___ 2, 13, 17, 18, 25, 34

Polygnathus dubius _-_-_-_ 14, 15, 29, 31, 32; pl. 18

dubius dubius, Polygnathus _._- 14, 15, 29, 31, 32; pl. 18

froms, Polygnathus _-_ 1, 14, 29; pl. 15
Falcodus guntharii

Fall Brook, N.Y

$-40$

Fall Creek, N.Y

Fir Tree Point, N.Y

fissurella, Styliolina

flabellatus, Bryantodus

44

flesus, Bryantodus

Flint Creek, N.Y

frons, Polygnathus dubius _-_-_-_- 1, 14, 29; pl. 15

G

Gage Gully, N.Y $8,14,50$ Genera and species, description of - 19 Genesee Formation, Genesco Shale Member of _- 2, 8, 9,

13,14

Genundewa Limestone Member of $3,8,9,11,13,14$,

Marathon Sandstone Member of the Ithaca

$15,16,17,18$

facies of

$-12$

occurrence of Conodonts in $s$

Penn Yan Shale Member of _-__-_9, 13, 14, 15, 16

Sherburne Flagstone Member of _-_-_-_ 9, 15

West River Shale Member of

13,16

Geneseo Shale Member of the Genesee

Formation

genundewa Probeloceras

$2,8,9,13,14$

genundewa, Probeloceras 9,16

Genundewa Limestone Member of the Genesee

Formation _-____ 3,8,9,11,13,14,15,16,17, 18

Genundewa Point, N.Y germana, Hindeodella - 41

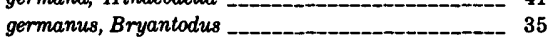

giganteus, Bryantodus -_-_-_-_-_-_ 37

gigas, Ancyrodella _...____________ 12, 16, 19, 21

Ancyrodella, Zone 12

glaber, Polygnathus -

Glenora Falls, N.Y _-_ 49

Gnamptognathus lipperti _-_______-__-_ 40

walliseri

Gondolella nodosa

Gorham, N.Y

grahami, Bryantodus _-___ 35,36

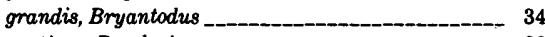

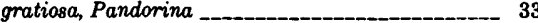

gratiosus, Spathogmathodus _ 33

guntharii, Enantiognathus _-_-_-_ 40; pls. 26, 27

Falcodus

H

Hamilton Group

Hamulosodina

Hemlock Outlet, N.Y sequerice of first appearances of conodonts in hermanni, Schmidtognathus _-_-_-__-_B11, 12, Schmidtognathus, Zone -

Hibbardella -_-_-__-_-_-_-_-_-_-_-_-_-_ 49

angulata

confertissima _-_-_- 43

subequalis _-

sp -

alternata

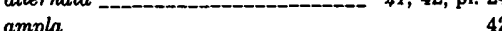

ampla
angulata

angulata _-__us _-_-_-_-_ 41, 42; pls. 24,25

compressa _______________ 42; $\mathrm{pl} 25$

elongata 42 ; pl. 25

germana _._____ 41

subtilis _._.____ 41,$42 ; \mathrm{pl} .25$

sp.

Hindeodellan elements

Hindeodina 41

holzapfeli, Crickites; Zone -

Honeoye Creek, N.Y

Hubbard Quarry, N.Y _- 48

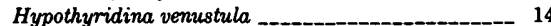

Icriodontidae 22

Icriodus alternatus _-
brevis

brevis

cymbiformis -

eslaensis _-_____ 8, 14,$22 ; \mathrm{pl}$.

latericrescens

latericrescens _____________ 8, $81,13,22 ; \mathrm{pl} .5$

latialatus
nodosus

curvirastratus _._._._____

nodosus 14,$28 ;$ pl. 5

symmetricus -

introlevatus _._. 24

Idioprioniodus _-_... 44

immersa, Ozarkodina _-_-_-_-_-_-_-_-_-_-_-_-_ 39

inequalis, Bryantodus

insita, Ctenognathus (Pandorinellina)

Pandorina _-..- 33

Pandorinellina _._

Pandorinellina, fauna ________ 15, 16

insitus, Ozarkodina

Spathognathodus _- 12

Introduction -

introlevatus, Icriodus symmetricus _.___________ 24

inversus, Apatognathus _-_____________-_ 39

Ithaca, N.Y -

Ithaca facies of the Genessee Formation, Marathon

Sandstone Member of

Williams Brook Coquinite Member of _-_-- $8,12,15$

\section{K}

Kashong Creek, N.Y

klapperi, Nothognathella

Koenenites

14,50

\section{L}

laevis, Warrenella

lata, Ozarkodina

latericrescens, Icriodus 8,22

Icriodus latericrescens _-_-_- $8,11,13,22 ;$ pl. 5 latericrescens latericrescens, Icriodus $8,11,13,22 ; \mathrm{pl} .5$ latialatus, Icriodus

latifossatus, Polygnathus

latimarginatus, Bryantodus

Leicester Marcasite Member of the Moscow

Formation 


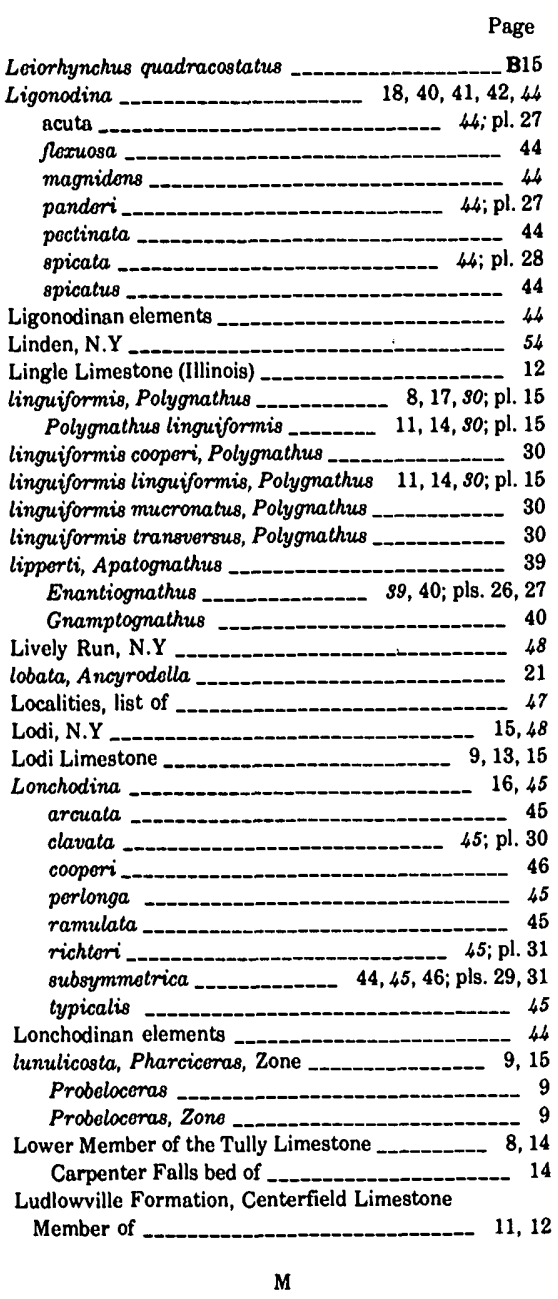

machaerodus, Bryantodus

macra, Ozarkodina $39 ; \mathrm{pl} .20$

37

macrodenta, Prioniodina _._______ 46 ; pls. 19, 28

macrodontus, Bryantodus _._-_-_-_._- 36, 46

Prioniodus

Maoniocoras torebratum

magnidono, Ligonodina

Manticocomas Lethe 13

cataphractum Zone -

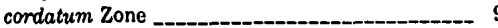

rhynchostoma Zone -.--_-_-_-_-_-_-_------ 9

styliophilum Zone _.____ 9, 16

Marathon Sandstone Member of the Ithaca facies of

the Genessee Formation -

marijas, Polygnathus rhonanus _-_-_--_ 1, $s 1$; pls. 17,18

masculus, Bryantodus _-

Menteth Gully, N.Y

Mesolaxis asymmetrica asymmotrica asymmetrica

Middle-Upper Devonian boundary _-_-_-_-_--.- 9

Mill Creek, N.Y

millori, Bryantodus 37

Moscow Formation, Leicester Marcasite

Member of _-.... $3,8,14,15,18$ Moscow Shale

Windon Member of mucronatus, Polygnathus linguiformis _._._______ 30

multidens, Bryantodus _._._-

mundus, Bryantodus

muricatus, Bryantodus

Prioniodus _-_-_-_-_-_-_-_ 36, 37

\section{$\mathbf{N}$}

natus, Polygnathus

B14

Neacondyladus 44

Neoprioniodontan elements

$\begin{array}{ll}\text { Neoprioniodontan elements _-_ } & s 9 \\ \text { Neoprioniodus } & \end{array}$ alatus armatus _ 9 ; pl. 23

New Albany Shale (Indiana)

nitens, Bryantodus nitens, Bryantodus
nitidus, Bryantodus ___________ $34,36,37 ; \mathrm{pl} .20$

nobilis, Bryantodus

nodosa, Ancyrodella

Gondolella 23,24

nodosus, Icriodus _._. $8,28,24$

Icriodus nodosus ____________ 14, 2s; pl. 5

nodosus curvirostratus, Icriodus _._._-_._-_-_ 23

nodosus nodosus, Icriodus _._____________ 14, 28; pl. 5

norrisi, Polygnathus $\quad 32 ;$ pl. 19

North Evans Limestone _._____ 2, 3, 8, 14, 15, 18

North Vernon Limestone (Indiana)

Nothognathella _._-_-_-_-_-_-_-_-_-_-_ 34, 38

klapperi

0

obstusus, Prioniodus 35 olentangiensis, Bryantodus 36 ordinatus, Polygnathus ______. 12, 13, s1; pls. 13, 14, 16 Oulodus

ovalis, Palmatolepis asymmetricus _ 26

Polygnathus asymmetricus ___ 12,26, 30;

$$
\text { pls. } 7,8,14,16
$$

Ovid, N.Y _-_ Ozarkodina _....... $18,34,39$

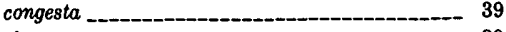
elegans _- 39 immersa -

insitus _lata

$39 ; \mathrm{pl} .20$

Ozarkodinan elements

\section{$\mathbf{P}$}

Palmatolepis $17,25,27$ asymmetricus ovalis disparalvea _-_-_-_-_-_-_-_.- 13, 15, 25; pl. 6 punctata _-_-_ 12,16 $-26$ ziegleri

panderi, Ligonodina _. Prioniodus 44 Prioniodus
Pandorina gratiosa insita.

Pandorinellina

12,$39 ; \mathrm{pl} .19$ Ctenognathus _. 33 fauna Parapolygnathus angusticostatus _-_-_-_-_-_-_-- 36

Partridge Point, Mich _._-_-_-_-_-_-_-_-_-_-_ 20

Pavilion

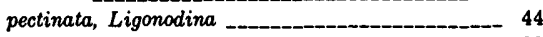

Pedavis

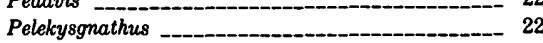

Penn Yan Shale Member of the Genesee

Formation 9, 13, 14, 15, 16 pennatus, Polygnathus _-_-_-_-_ 12, 13, 15, s1; pl. 12 peracuta, Polygnathus

Schmidtognathus

peracutus, Polygnathus _ 13, 15, s1; pls. 11, 13, pergracilis, Angulodus _-_____- 41

perlatum, Ponticeras _- 9

Ponticeras, Zone _-_

perlonga, Lonchodina

petilus, Bryantodus
Pharciceras _._- Page

amplexum -

unulicosta Zone

pietzneri, Schmidtognathus 12

pietznori, Schmidtognathus _-_
Pike Creek, N.Y

Pike Creek, N.Y -
planus, Bryantodus

Spathognathodus ____________ 13, 14

Platform elements -_-__-_-_-_ 19

Plectospathodus _._______________________-_ 41

Polygnathelius _-_-_ 34 colligatus

Polygnathus ________________ 9, 15, 17, 25, 39

alatus _ 25; pls. 6, 7

alveoliposticus _-_ 14, $25 ;$ pls. 6,7

angustidiscus _.____________ 25, 27; pl. 17

asymmetricus ______-__-_ 12, 13, 15, 28, 29, 38 asymmetricus __________ 25, 26; pls. 7, 8 ovalis ___ $12,26,30$; pls. $7,8,14,16$ unilabius _-_ 1, 26; pls. 7, 8 Zone _-_ 12,15 beckmanni_____-_ 11, 13, 27

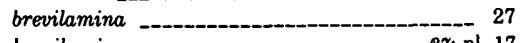

brevilaminus ________________._. 27; pl. 17 bryanti caelatus _._-_ 13, 27,28 ; pls. 11, 12, 13 collieri___- 1, 16, 27; pls. 9, 10,11,12,13 cristata ___ 26,30

cristatus __._. $12,13,16,28,34$; pls. 9,10 sensu sensu _- 26 decorosus _- 13, 25, 29; pl. 17 deformis dengleri dubia dubia _ asymmetrica dubia 25,26

dubius $2,13,17,18,25,34$ dubius___- 14, 15, 29, 31, 32; pl. 18

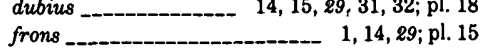
ectypa ectypus _-_._._. 13, 14, 15, 26, 28, 30 ; pls. 7, 9 glaber latifossatus _-_-_- 11 latifossatus _-_-_-_
linguiformis _-__-_ linguiformis _._._._._. $11,14, s 0 ; \mathrm{pl} .15$

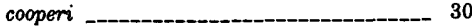
mucronatus _-_._-_._- 30

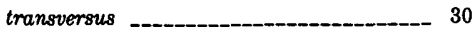

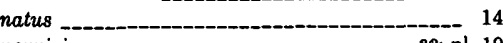
norrisi ordinatus _-_-_-_ror $\begin{array}{r}12,13, s, \text { pls. } 13,14,16 \\ \text { pennatus }\end{array}$ pennatus -_-_-_-_-_-_ 12, 13, 15, 31; pl. 12 peracuta

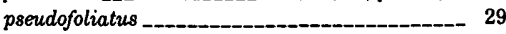

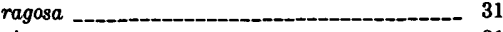
rhenanus _._.___ 31 marijae _-_-_-_ $1, s 1 ;$ pls. 17,18 robusticostatus _-___-__-__-_ 27 rotundilobus -
trigonicus tuberculatus _-_._- 14, 19, 28, s2; pls. 11, 12, 13 varcus $8,11,14,29,32,33,34$ Zone _-_ $\quad 8,11,14,29,32,33,34$

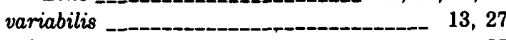

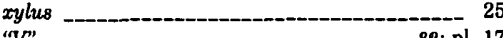
" $V$ " -

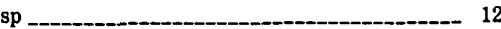
Polynathellus curvatus _._-

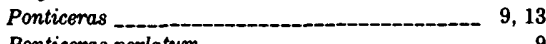

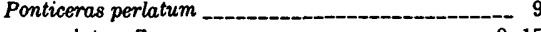
perlatum Zone _-_ 9,15 pravulus, Prioniodus __-___- 36,37 pravus, Bryantodus _-_-_-_-_ 37 Prioniodus

Prioniodella torta 


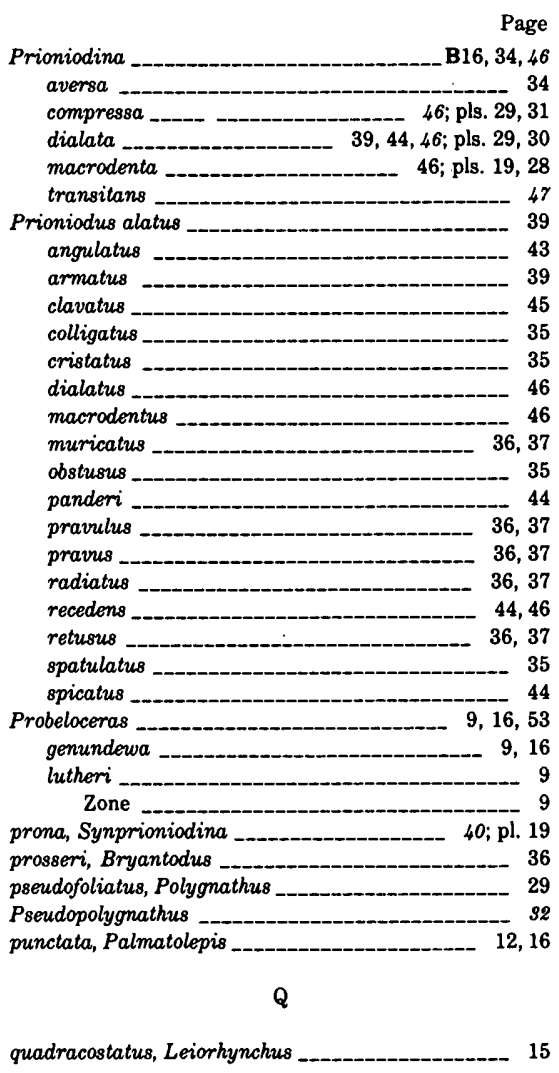

R

radiatus, Bryantodus Prioniodus ragosa, Polygnathus ramulata, Lonchodina 45 Rapid Member of the Cedar Valley Limestone ------ 12 recedens, Prioniodus 44, 46 regularis, Synprioniodina _-_-_-_-_-_-_-_-_--- 40 Renwick Brook, N.Y retusus, Bryantodus _._._._ 16, 17, 31, 32, 34, 35, s6, 39,

Prioniodus 45 ; pls. 20

36,37 rhenanus, Polygnathus _-__-__-____-__-_-_ 31 rhenanus marijae, Polygnathus _._._._. 1, 31 ; pls. 17, 18 Rhinestreet Shale Member of the West Falls

Formation

rhynchostoma, richteri, Lonchodina _._._._._._._._-_ 45; pl. 31 rabusticostatus, Polygnathus _-_____-_-_-_-_ 27 robustus, Bryantodus rotundiloba, Ancyrodella __ 12, 13, 15, 16, 18, 19, 20 Ancyrodella, fauna Zone Ancyrodella rotundiloba -_-_--- 17, 19, 21; pls. 1,3 rotundiloba alata, Ancyrodella _._-__-__ 13, 20; pls. 1,2 rotundiloba rotundiloba, Ancyrodella $17,19,21$; pls. 1, 3 rotundilobus, Polygmathus
rugosa, Ancyrodella

sannemanni, Spathognathodus 3s; pl. 19 Spathognathodus sannemanni

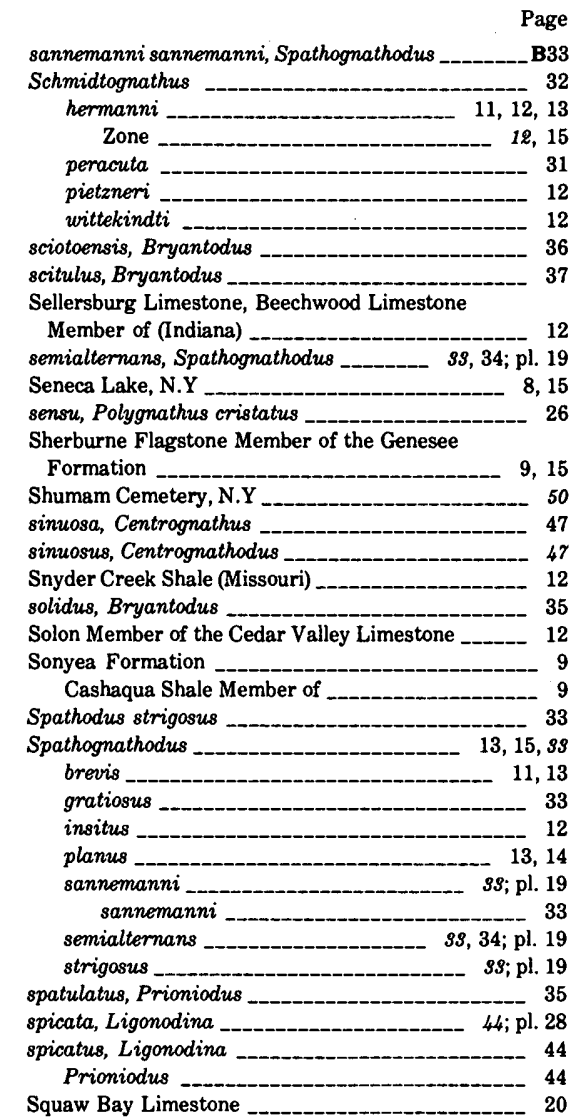

Standish Formation, Crosby Sandstone

Member of

$3,15,16$

stratfordensis, Bryantodus _..-- 36 strigosus, Spathodus

Spathognathodus $39 ; \mathrm{pl} .19$

Styliolina fissurella ______________-_ 17

styliophilum, Manticoceras, Zone

Subbryantodus

subequalis, Hibbardella

subsymmetrica, Lonchodina _.___- 44, 45, 46; pls. 29,31 subtilis, Hindeodella Sunset Point Gully, N.Y

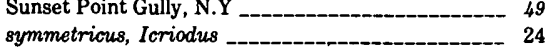
symmetricus introlevatus, Icriodus:_-_._-_-_-_- 24 Synprioniodina

alternata ___ 40 ; pls. 19,23
$40 ;$ pl. 19

prona 40; pl. 19 regularis Systematic paleontology $\mathrm{T}$

Taughannock Creek, N.Y Taughannock Falls State Park, N.Y _-__-_-_ 14, 15 Taughannock Point, N.Y -_-_-_-_-_-_-- 48 Taunton Gully, N.Y Taxonomy _-_ 16 terebratum, Maenioceras _._-_____-_-_-_ 11 Tinkers Falls, N.Y 11
$-\quad 47$
8 the Tully Limestone $\begin{array}{lr}\text { Tommy Creek, N.Y } & 48 \\ \text { Tornoceras } & 15,47\end{array}$

torta, Prioniodella
tortus, Bryantodus
transitans, Palmatolepis
Prioniodina $\begin{array}{r}\text { Page } \\ \text { transversus, Polygnathus linguiformis } \\ \text { Traverse Group (Michigan) } \\ \text { triangularis, Ancyrognathus, Zone } \\ \text { Trichognathus blanda } \\ \text { Trichonodella } \\ \text { blanda } \\ \text { trigonicus, Polygnathus } \\ \text { tuberculatus, Polygnathus } \\ \text { Tully Limestone } \\ \text { Apulia Member of } \\ \text { Carpenter Falls bed of the Lower Member of } \\ \text { Lower Member of } \\ \text { Tinkers Falls Member of }\end{array}$

unilabius, Polygnathus asymmetrious _-- 1, 26; pls. 7, 8 Upper Member of the Tully Limestone _-____ 8, 14

\section{V}

varcus, Polygnathus

Polygnathus, Zone $8,11,14,29,32,33,34$ ariabilis, Polygnathus venustula, Hypothyridina _-_-_-__- 14

Voorhys Gully, N.Y

\section{W}

walliseri, Gnamptognathus 40 walrathi, Angulodus 41,42

41,42

Warrenella laevis

Washburn Cemetery, N.Y

Watkins Glen, N.Y

wesleyianensis, Bryantodus _-_...-. 37

West Brook Member of the Tully Limestone -_-_ 8

West Falls Formation

Rhinestreet Shale Member of _-_-_-_...- 3

West River Shale Member of the Genessee

Formation

White Creek, N.Y

$Y$

Wilder Run, N.Y _-______-_ 16,51

Williams Brook, N.Y

Williams Brook Coquinite Member of the

Ithaca facies

Willow Grove Gully, N.Y

winchelli, Bryantodus

winchelli, Bryantodus
Windom Member of the Moscow Shale

wittekindti, Schmidtognathus _-_._.

$\mathbf{X}$

xylus, Polygnathus 25

ziegleri, Nothognathella 98; pl. 18 Palmatolepis
38 26 47
30 .

.




\section{PLATES 1-31}

Contact photographs of the plates in this report ane available at cost, from U.S. Geological Survey Library, Federal Center, Denver, Colorado 80225 . 


\section{PLATE 1}

[A]l specimens about $\times 30$. Figs. $1,3-5,8,11-13,15,17,25-27$ coated; others not coated]

Figures 1-8,11-17. Ancyrodella rotundiloba rotundiloba (Bryant) (p. B19).

1,2. Oral and aboral views of the lectotype, USNM 135043, North Evans Limestone of Rickard (1964), Eighteenmile Creek.

3. Oral view, USNM 188947, Penn Yan Shale Member of Genesee Formation, USGS 4576-SD, Cayuga Creek (Dp-3). This specimen retains the basal plate.

4, 5. Aboral and oral views, USNM 188910; USGS 6718-SD, Penn Yan Shale Member of Genesee Formation, Genundewa Point (Nap-4).

6-8. Side, oral, and aboral views, USNM 188932; USGS 4538-SD, Leicester Marcasite Member of Moscow Formation of Sutton (1951), Eighteenmile Creek (Ed-1).

11-13. Oral, lateral, and aboral views, USNM 188934; USGS 4538-SD, Leicester Marcasite Member of Moscow Formation of Sutton (1951), Eighteenmile Creek (Ed-1).

14,15. Oral and aboral views, USNM 188935; USGS 4538-SD, Leicester Marcasite Member of Moscow Formation of Sutton (1951), Eighteenmile Creek (Ed-1).

16,17. Oral and aboral views, USNM 188949; USGS 6759-SD, Crosby Sandstone Member of Standish Formation as used by Torrey and others (1932), Willow Grove (Py-14).

9, 10, 23-27. Ancyrodella rotundiloba alata Glenister and Klapper (p. B20).

9,10. Oral and aboral views, USNM 188937; USGS 8122-SD, West River Shale Member of Genesee Formation, Fall Brook (Cl-4).

23,24. Oral and aboral views, USNM 188924; USGS 3958-SD, Genundewa Limestone Member of Genesee Formation, Genundewa Point (Nap-4).

25. Oral view, USNM 188942; USGS 4577-SD, Genundewa Limestone Member of Genesee Formation, Cayuga Creek (Dp-3).

26, 27. Oral and aboral views, USNM 188943; USGS 4577-SD, Genundewa Limestone Member of Genesee Formation, Cayuga Creek (Dp-3).

18-22. Ancyrodella rugosa Branson and Mehl (p. B21).

18, 19. Oral and aboral views, USNM 188936; USGS 8122-SD, West River Shale Member of Genesee Formation, Fall Brook ( $\mathrm{Cl}-4)$. Note the nearly complete secondary keels.

20-22. Oral, aboral, and oblique views, USNM 188930; USGS 6754-SD, West River Shale Member of Genesee Formation, Chidsey Point (Py-7). 


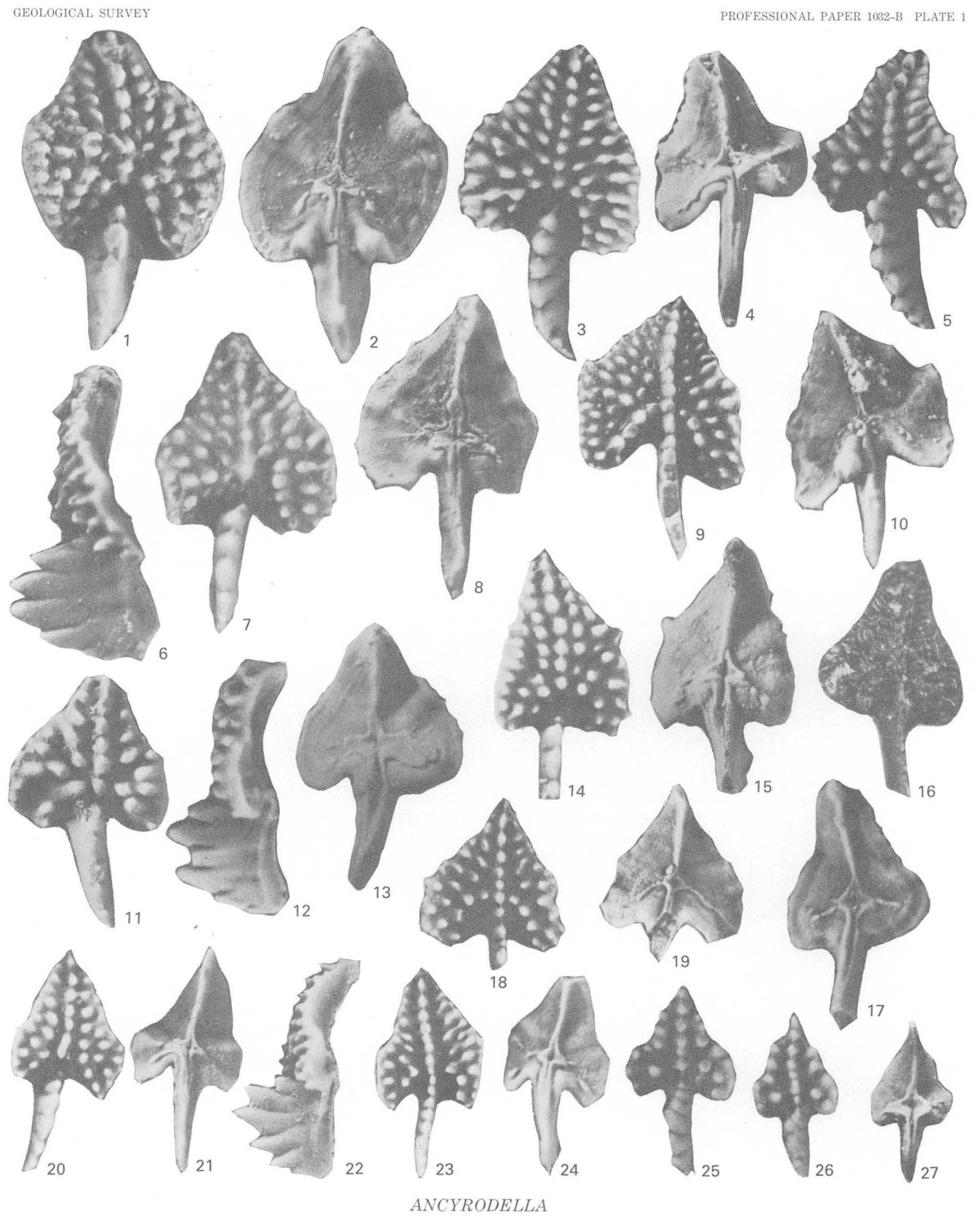




\section{PLATE 2}

[All specimens about $\times 30$. Figs. $1,2,5,8,12,13,15,18,20,24$ not coated; others coated]

FigURES 1-28. Ancyrodella rotundiloba alata Glenister and Klapper (p. B20).

1, 2. Oral and aboral views of a juvenile; USNM 188913; USGS 3958-SD, Genundewa Limestone Member of Genesee Formation, Genundewa Point (Nap-4).

3. Oral view, USNM 188916; USGS 6754-SD, West River Shale Member of Genesee Formation, Chidsey Point (Py-7).

4, 5. Oral and aboral views, USNM 188925; USGS 3958-SD, Genundewa Limestone Member of Genesee Formation, Genundewa Point (Nap-4).

6. Oral view, USNM 188923; USGS 3958-SD, Genundewa Limestone Member of Genesee Formation, Genundewa Point (Nap-4).

7,8. Oral and aboral views, USNM 188946; USGS 8122-SD, West River Shale Member of Genesee Formation, Fall Brook (Cl-4).

9, 10. Oral and aboral views, USNM 188928; USGS 6754-SD, West River Shale Member of Genesee Formation, Chidsey Point ( $\mathrm{Py}-7)$. Intermediate to $A$. curvata.

11. Oral view, USNM 188948; USGS 3958-SD, Genundewa Limestone Member of Genesee Formation, Genundewa Point (Nap-4).

12-14. Oral, aboral, and lateral views, USNM 188921; USGS 6754-SD, West River Shale Member of Genesee Formation, Chidsey Point (Py-7).

15,16. Oral and aboral views, USNM 188917; USGS 6754-SD, West River Shale Member of Genesee Formation, Chidsey Point (Py-7).

17, 18. Oral and aboral views, USNM 188950; USGS 3958-SD, Genundewa Limestone Member of Genesee Formation, Genundewa Point (Nap-4).

19. Oral view, USNM 188909; USGS 6754-SD, West River Shale Member of Genesee Formation, Chidsey Point (Py-7). Intermediate to A. curvata.

20,21. Oral and aboral views, USNM 188915; USGS 6754-SD, West River Shale Member of Genesee Formation, Chidsey Point (Py-7).

22. Oral view, USNM 188927; USGS 3958-SD, Genundewa Limestone Member of Genesee Formation, Genundewa Point (Nap-4).

23, 24. Oral and aboral views, USNM 188938; USGS 8122-SD, West River Shale Member of Genesee Formation, Fall Brook (Cl-4).

25,26. Oral and aboral views, USNM 188940; USGS 3958-SD, Genundewa Limestone Member of Genesee Formation, Genundewa Point (Nap-4).

27, 28. Oral and aboral views, USNM 188914; USGS 3958-SD, Genundewa Limestone Member of Genesee Formation, Genundewa Point (Nap-4). 
GEOLOGICAL SURVEY

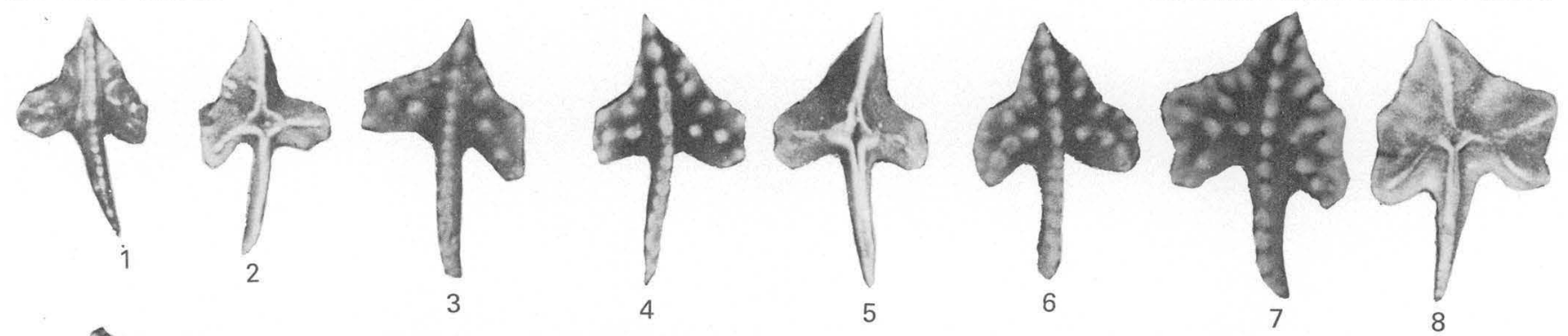

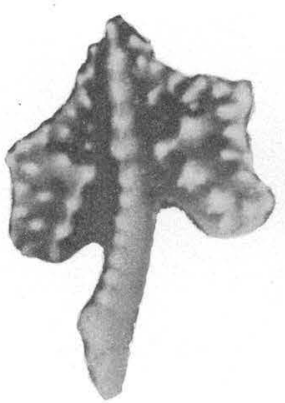

9
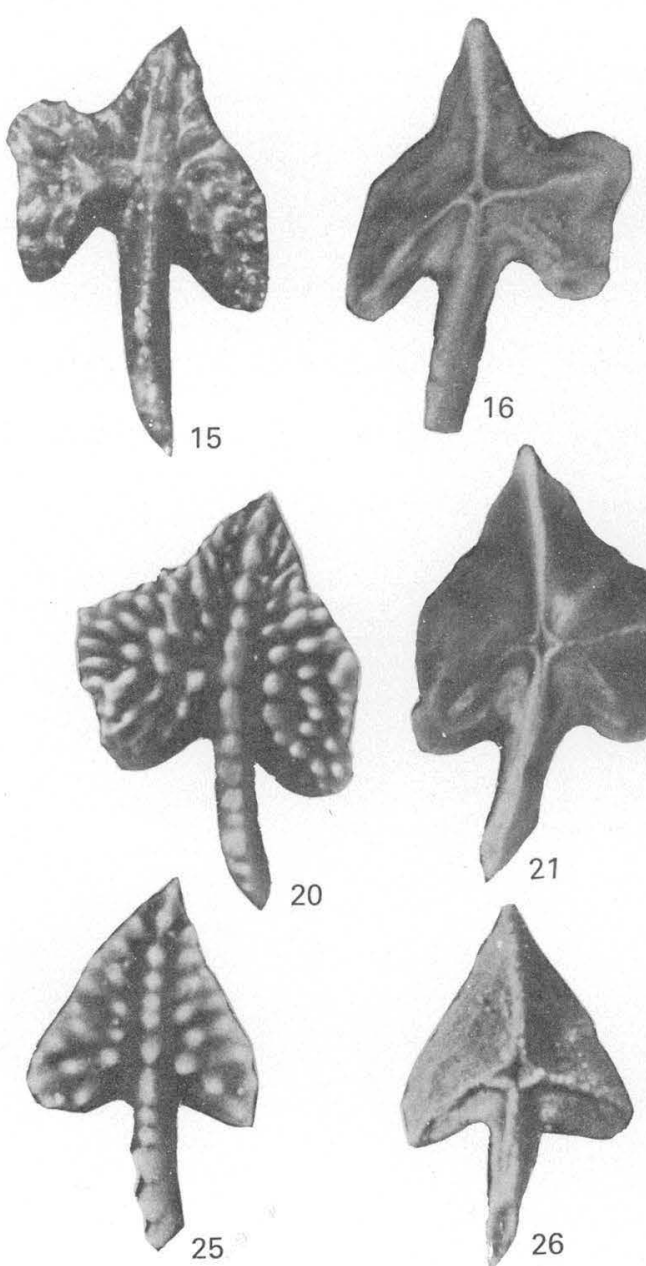

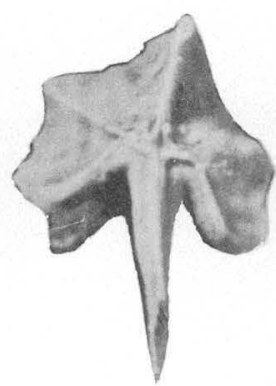

10
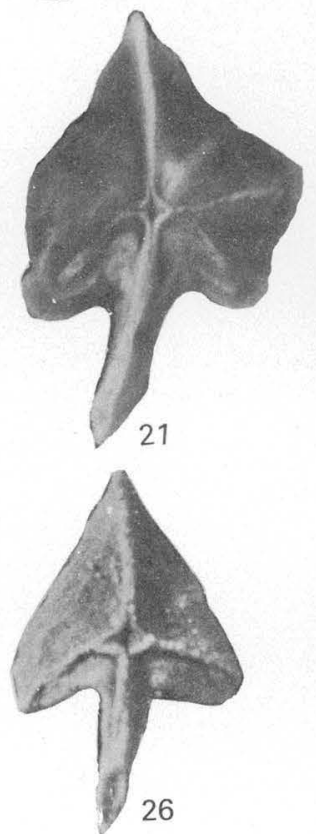
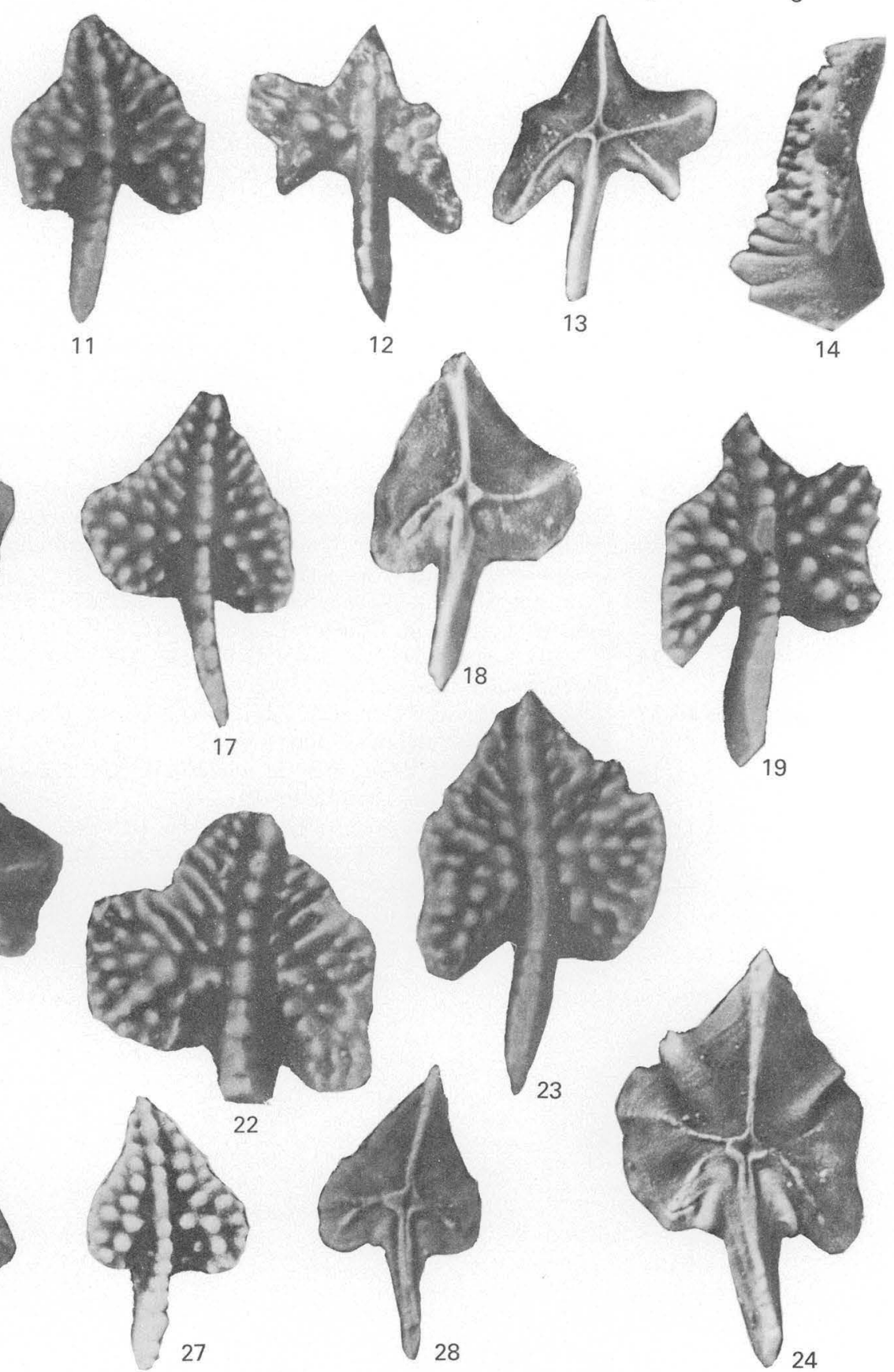

ANCYRODELLA 


\section{PLATE 3}

[All specimens about $\times 30$. Figs. 3, 9, 13 uncoated; others coated]

Figures 1-19. Ancyrodella rugosa Branson and Mehl (p. B21).

1-3. Oral, aboral, and lateral views, USNM 188929; USGS 6754-SD, West River Shale Member of Genesee Formation, Chidsey Point (Py-7). Transitional to A. gigas.

4. Oral view, USNM 188926; USGS 3958-SD, Genundewa Limestone Member of Genesee Formation, Genundewa Point (Nap-4). The specimen has strong, incomplete secondary keels.

5. Oral view, USNM 188922; USGS 3976-SD, West River Shale Member of Genesee Formation, Bristol Center (Cd-5).

6, 7. Oral and aboral views, USNM 188911; USGS 6791-SD, upper Ithaca Member of Genesee Formation, Coy Glen (I-3).

8,9. Oral and aboral, uncoated to show conodont basal plate, USNM 188912; USGS 6791-SD, upper Ithaca Member of Genesee Formation, Coy Glen (I-3).

10. Oral view, USNM 188933; USGS 3952-SD, Genundewa Limestone Member of Genesee Formation, Genundewa Point (Nap-4).

11-13. Oral, aboral, and lateral views, USNM 188931; USGS 6754-SD, West River Shale Member of Genesee Formation, Chidsey Point (Py-7).

14, 15. Oral and aboral views, USNM 188919; USGS 6754-SD, West River Shale Member of Genesee Formation, Chidsey Point (Py-7).

16,17. Oral and aboral views, USNM 188944; USGS 6718-SD, Penn Yan Shale Member of Genesee Formation, Genundewa Point (Py-7).

18, 19. Oral and aboral views, USNM 188951; USGS 6754-SD, West River Shale Member of Genesee Formation, Chidsey Point (Py-7).

20,21. Ancyrodella rotundiloba rotundiloba (Bryant) (p. B19).

Oral and aboral views, USNM 188941; USGS 4538-SD, Leicester Marcasite Member of Moscow Formation of Sutton (1951), Eighteenmile Creek (Ed-1). 


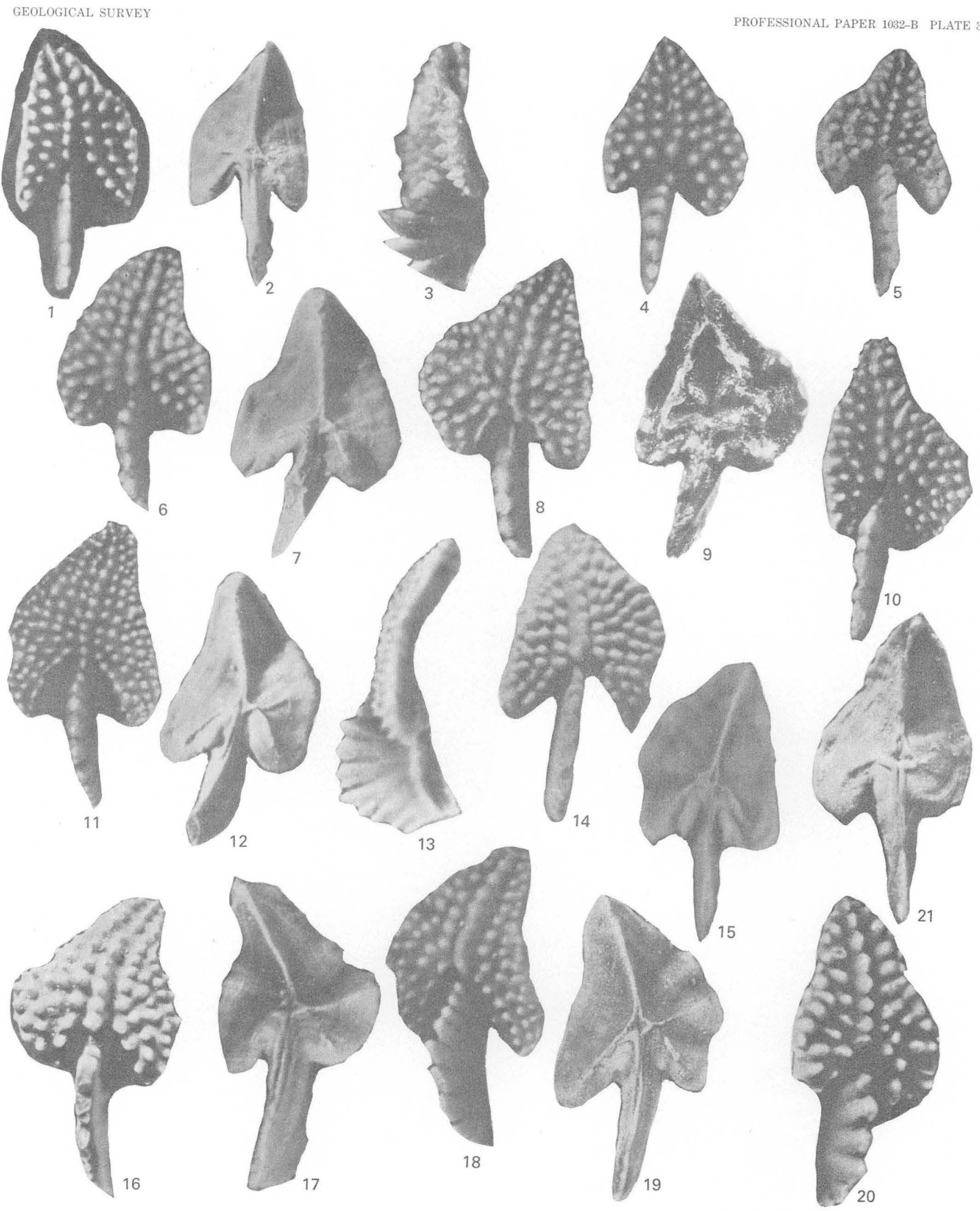

ANCYRODELLA 


\section{PLATE 4}

[All figures about $\times$ 30. Figs. 2-4, 28, 29 coated; others not coated. All specimens from the Tully Limestone at Gage Gully (Cd-12) except as noted]

Figures 1-29. Icriodus eslaensis Adrichem Boogaert (p. B22).

Oral, aboral, and lateral views.

1-3. USNM 188897; USGS 6733-SD.

4-6. USNM 188895; USGS 6733-SD.

7-9. USNM 188901; USGS 6732-SD, Leicester Marcasite Member of Moscow Formation of Sutton (1951), Gage Gully (Cd-12).

10-12. USNM 188889; USGS 6733-SD.

13-15. USNM 188896; USGS 6733-SD.

16-18. USNM 188888; USGS 6733-SD.

19-21. USNM 188892; USGS 6733-SD.

22-24. USNM 188887; USGS 6733-SD.

25-27. USNM 188886; USGS 6733-SD.

28, 29. USNM 188894; USGS 6733-SD. 
GEOLOGICAL SURVEY
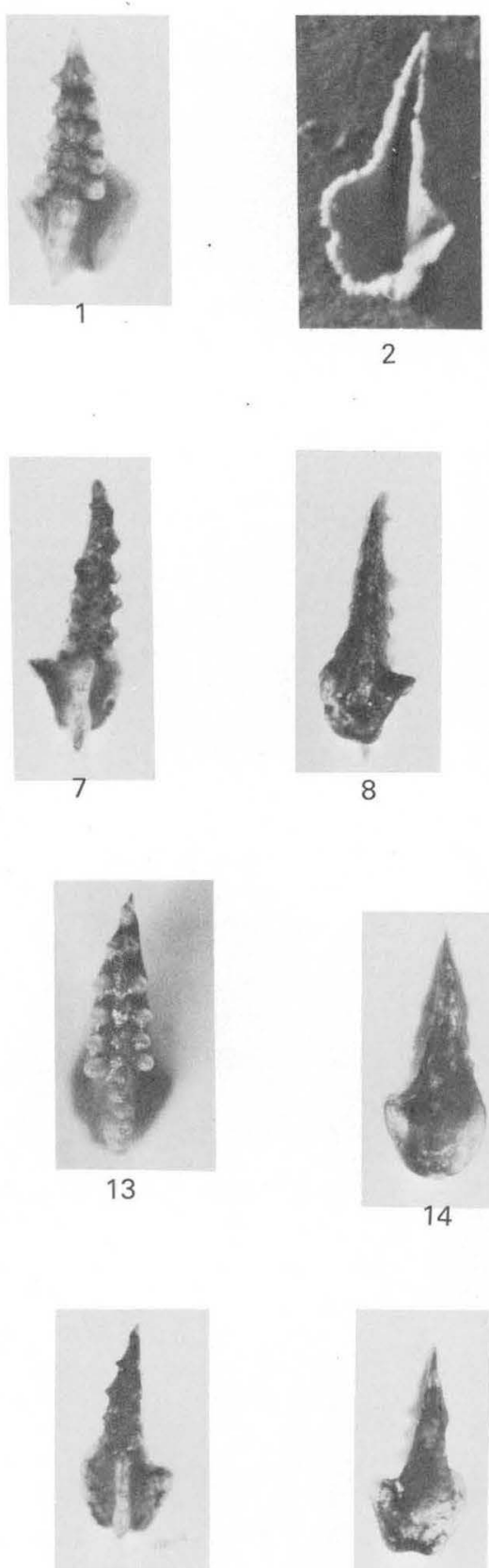

19
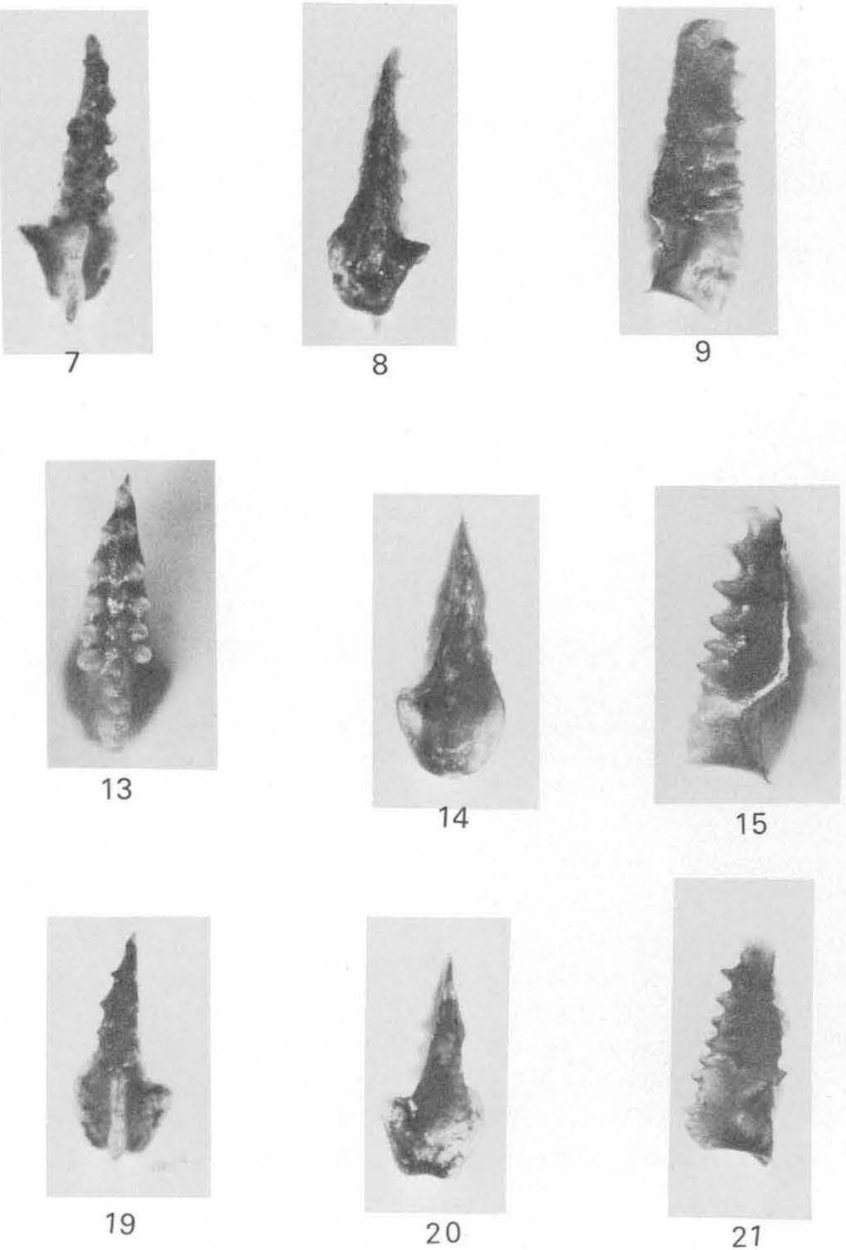
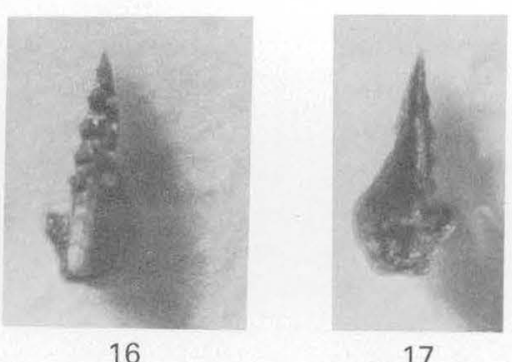

17
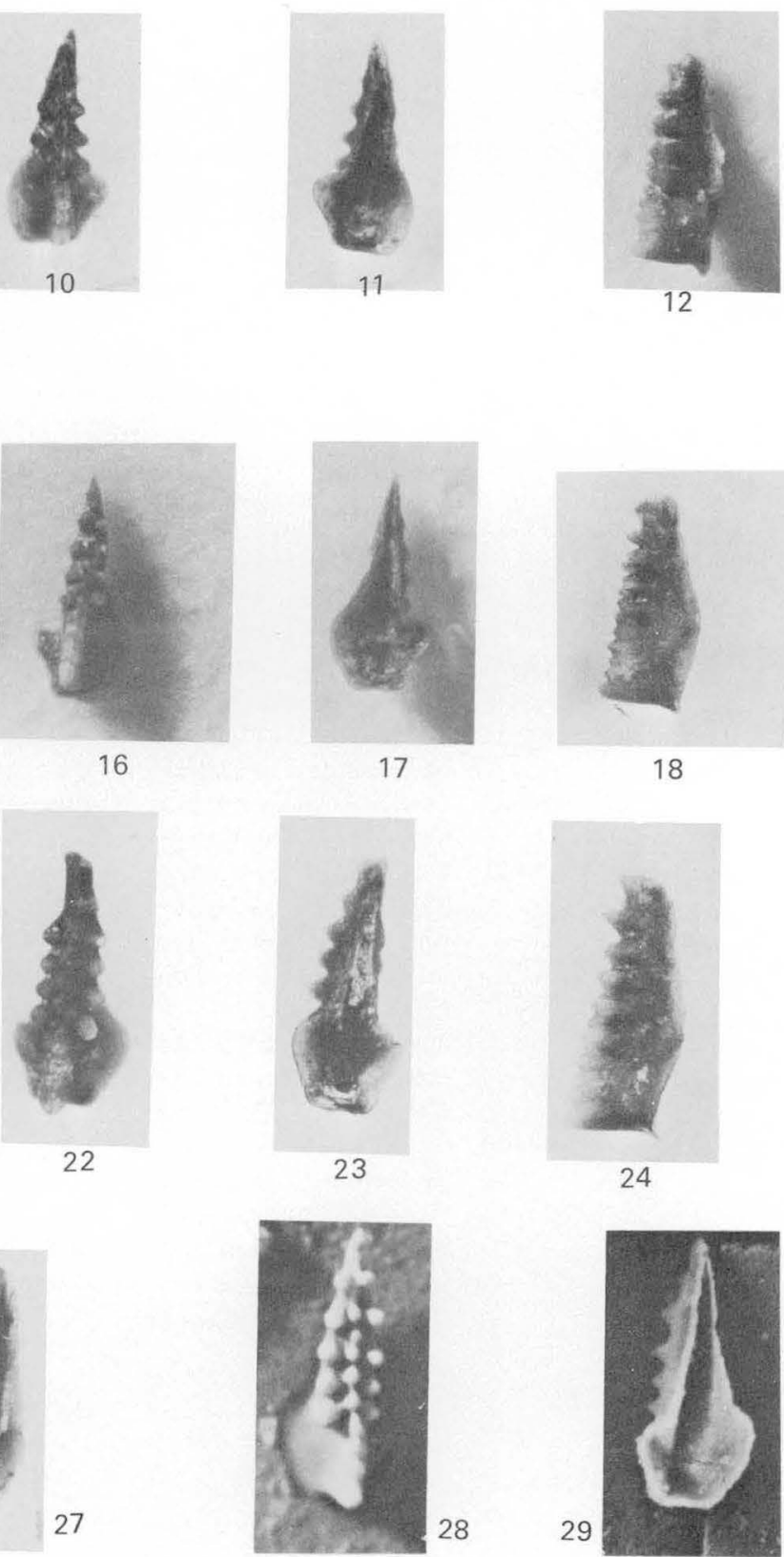

28
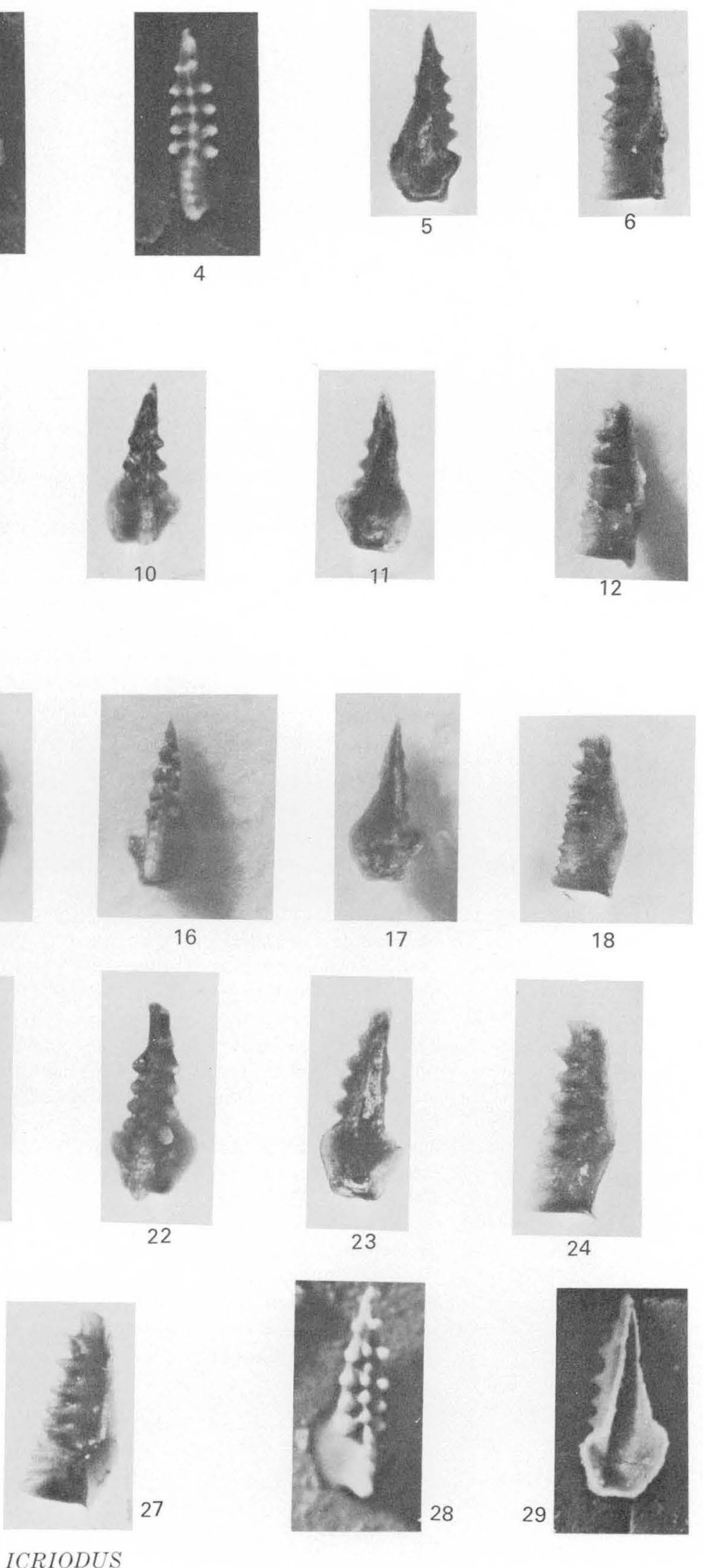

ICRIODUS
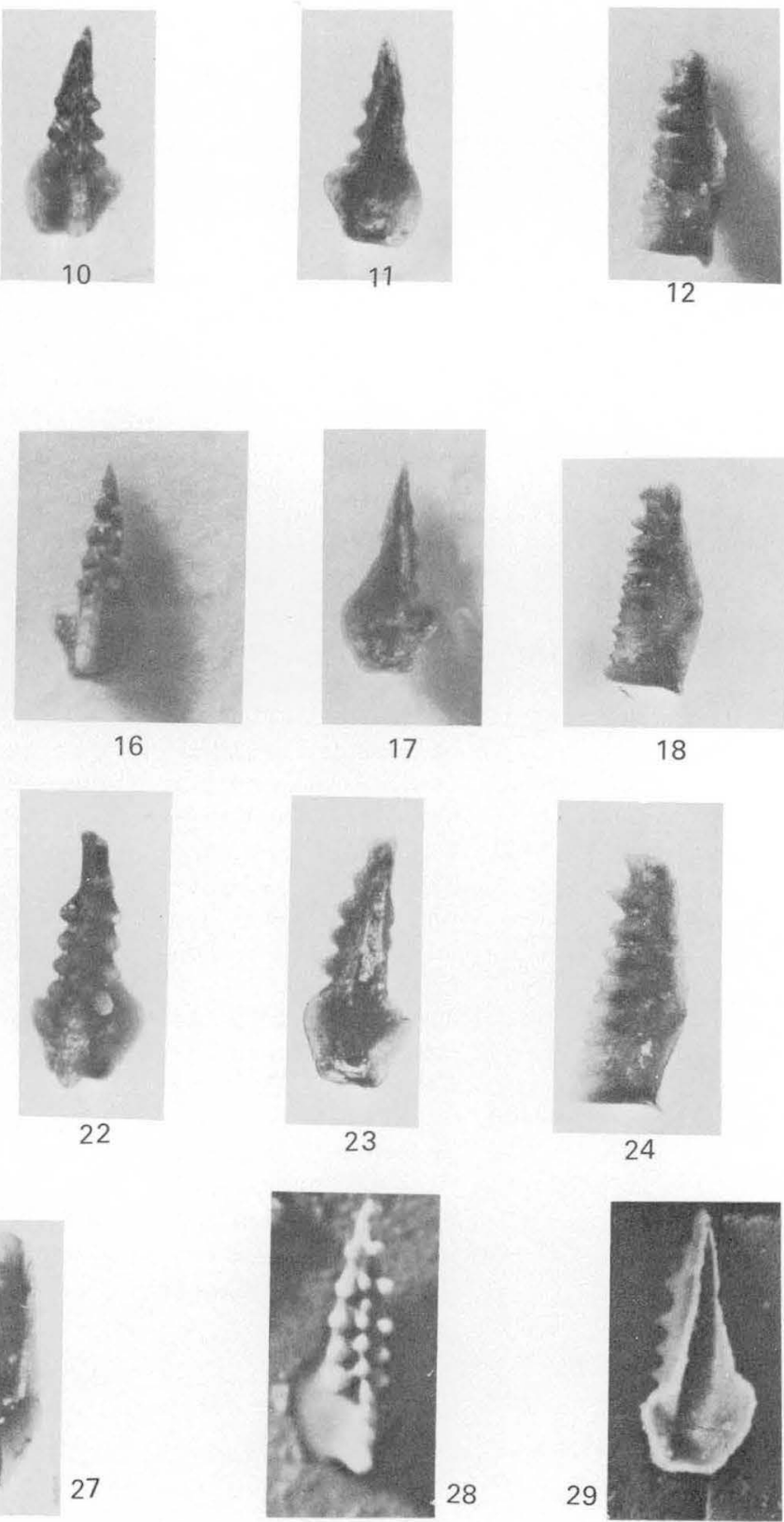


\section{PLATE 5}

[Figs. 1-27, 41, 42, $\times$ 30. Figs. 28, 29, 31-40, 43-45, $\times$ 45; Fig. 30, $\times 60$. Figs. 1-27, 30, 40-42, 45 uncoated; others coated]

FiguRes 1-6. Icriodus latericrescens latericrescens Branson and Mehl (p. B22).

Oral, aboral, and lateral views.

1-3. USNM 188904; USGS 7622-SD. North Evans Limestone of Rickard (1964). Note basal filling in aboral view.

4-6. USNM 188890; USGS 4553-SD, Genundewa Limestone Member of Genesee Formation, Cazenovia Creek (Dp-1). Basal filling present.

7-45. Icriodus nodosus nodosus (Huddle) (p. B23).

7-9. Oral, aboral, and lateral views, USNM 188898; USGS 6740-SD, Tully Limestone, Bellona (Ph7). Note lack of nodes in median row near posterior tip.

10-12. Oral, aboral, and lateral views, USNM 188902; USGS 4538-SD, North Evans Limestone of Rickard (1964), Eighteenmile Creek (Ed-1).

13-15. Oral, aboral, and lateral views, USNM 188884; USGS 4536-SD, Genundewa Limestone Member of Genesee Formation, Pike Creek (SC-1).

16-18. Oral, aboral, and lateral views, USNM 188883; USGS 4525-SD, Genundewa Limestone Member of Genesee Formation, Pike Creek (SC-1).

19-21. Oral, aboral, and lateral views, USNM 188882; USGS 8970-SD, Genundewa Limestone Member of Genesee Formation, Bethany Center (Ba-3).

22-24. Oral, aboral, and lateral views, USNM 188885; USGS 4525-SD, Genundewa Limestone Member of Genesee Formation, Pike Creek (SC-1).

25-27. Oral, aboral, and lateral views, USNM 188906; USGS 8970, Genundewa Limestone Member of Genesee Formation, Bethany Center (Ba-3).

28-31. Oral, coated and uncoated aboral, and lateral views. Paratype, Gondolella? nodosa Huddle, USNM 208015. New Albany Shale, 15 feet above base, loc. 33 of Huddle (1934). Aboral rim of basal expansion is broken, but enough remains to be sure that it had hook or spur. Trough beneath spur is present and is indicated on outline of the inner rim in fig. $30, \times 60$.

32-34. Gondolella? nodosa with a broken posterior tip. Paratype, USNM 208016. Oral, aboral, and lateral views from same collection as USNM 208015.

35-37. Oral, aboral, and lateral views, USNM 208017; USGS 9306-SD, New Albany Shale, Speed, Ind. Collector, C. B. Rexroad.

38-40. Oral, aboral and lateral views, USNM 208018; USGS 9036-SD, New Albany Shale, Speed, Ind. Collector, C. B. Rexroad.

41, 42. Oral and aboral views, USNM 188893; New Albany Shale, Speed, Ind. Same locality as USGS 9036-SD. Collector, C. A. Pollock.

43-45. Oral, aboral, and lateral views, USNM 208019; USGS 9036-SD, New Albany Shale, Speed, Ind. Collector, C. B. Rexroad. 

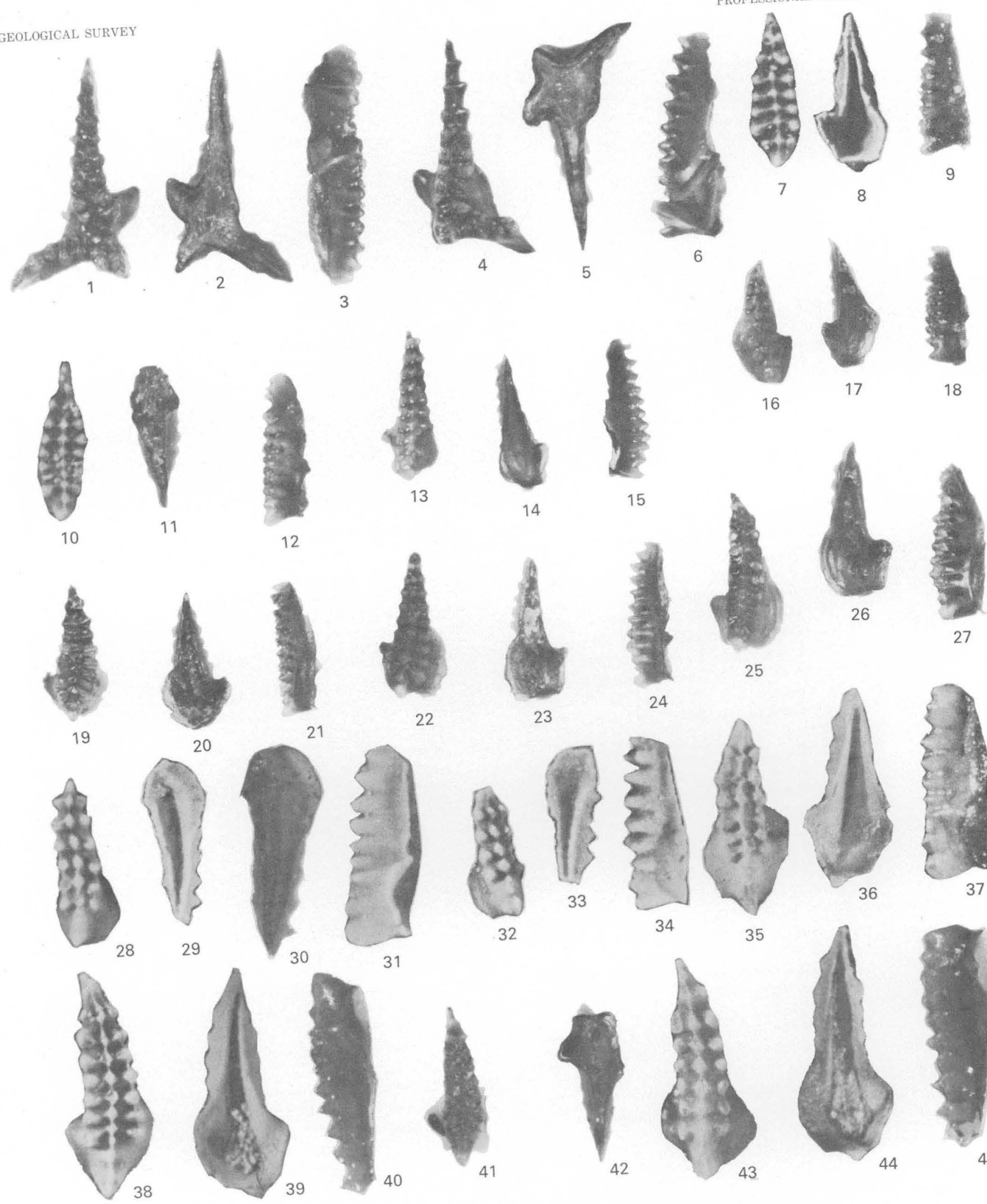

25
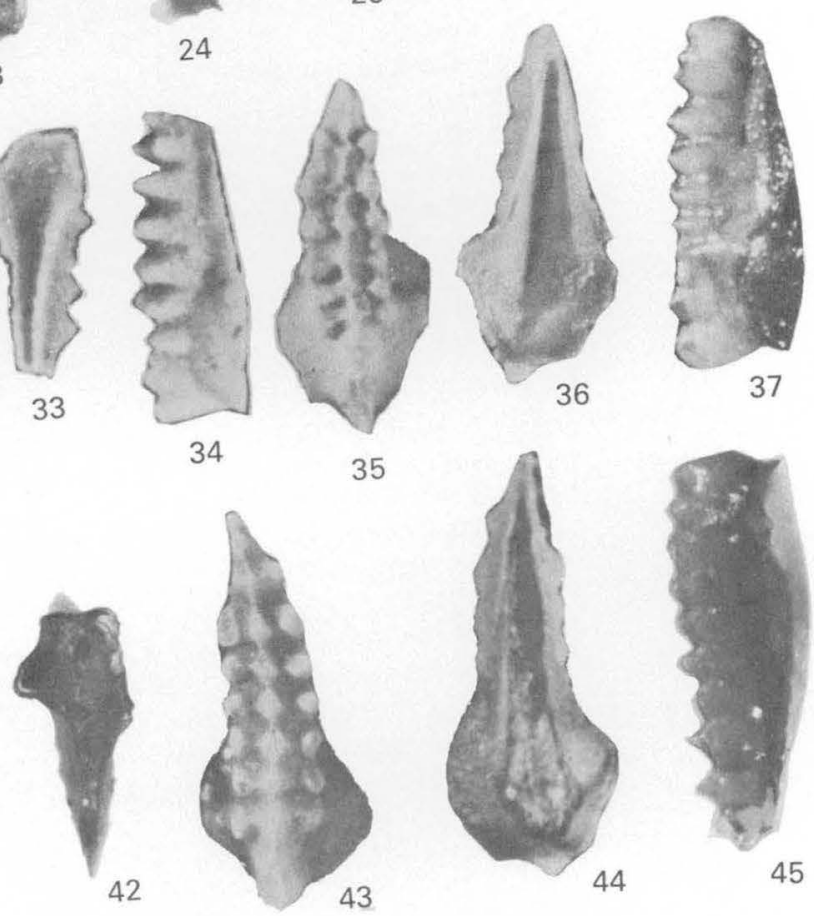

ICRIODUS 


\section{PLATE 6}

[Figs. 15, 24-28 $=\times 35$; others $\times 30$. All specimens coated except fig. 5]

Figures 1-7. Palmatolepis? disparalvea Orr and Klapper (p. B25).

1,2. Oral and aboral views, USNM 188670; USGS 7622-SD, North Evans Limestone of Rickard (1964), Eighteenmile Creek (Ed-1).

3. Oral view, USNM 188671; USGS 4567-SD, (free blade broken off) Geneseo Shale Member of Genesee Formation, Elevenmile Creek (At-1).

4,5. Oral and aboral views, USNM 188672; USGS 4567-SD, Geneseo Shale Member of Genesee Formation, Elevenmile Creek (At-1).

6, 7. Aboral and oral views, USNM 188673; USGS 4567-SD. Lower part of the free blade broken off. Geneseo Shale Member of Genesee Formation, Elevenmile Creek (At-1).

8-14. Polygnathus alveoliposticus Orr and Klapper (p. B25).

8,9. Aboral and oral views, USNM 188684; USGS 6733-SD, Tully Limestone, Gage Gully (Cd-12).

10,11. Aboral and oral views, USNM 188683; USGS 6733-SD, Tully Limestone, Gage Gully (Cd-12).

12. Oral view, USNM 188685; USGS 6733-SD, Tully Limestone, Gage Gully (Cd-12).

13, 14. Oblique view, showing thin plate, and oral view, USNM 188686; USGS 6733-SD, Tully Limestone, Gage Gully (Cd-12).

15-23. Polygnathus dengleri Bischoff and Ziegler (p. B30).

15. Aboral view, USNM 188702; USGS 6718-SD, Penn Yan Shale Member of Genesee Formation, Genundewa Point (Nap-4). Shows typical shape of basal pit.

16. Oral view, USNM 188703; USGS 8122-SD, West River Shale Member of Genesee Formation, Fall Brook (Cl-4).

17,18. Aboral and oral views, USNM 188701; USGS 4557-SD, Genundewa Limestone Member of Genesee Formation, Cazenovia Creek (Dp-1).

19, 20. Oral and aboral views, USNM 188700; USGS 4537-SD, Penn Yan Shale Member of Genesee Formation, Eighteenmile Creek (Ed-1).

21-23. Oral, oblique-lateral, and aboral views, USNM 188704; USGS 4526-SD, Genundewa Limestone Member of Genesee Formation, Pike Creek (SC-1).

24-28. Polygnathus alatus Huddle (p. B25).

24. Oral-oblique view of an immature specimen, USNM 188680; USGS 4538-SD, Leicester Marcasite Member of Moscow Formation of Sutton (1951) (Ed-1). Note faint nodes on rims and broken free blade.

25. Oral view, USNM 188676; USGS 6759-SD, Crosby Sandstone Member of Standish Formation as used by Torrey and others (1932), in Ithaca Member of Genesee Formation, Willow Grove (Py-14).

26. Oral-oblique view, USNM 188674; USGS 4577-SD, Genundewa Limestone Member of Genesee Formation, Cayuga Creek (Dp-3).

27. Oral view, USNM 188677; USGS 7622-SD, North Evans Limestone of Rickard (1964) (Ed-1).

28. Oral view of specimen with a long free blade, USNM 188675; USGS 4576-SD, Penn Yan Shale Member of Genesee Formation, Cayuga Creek (Dp-3). 
GEOLOGICAL SURVEY
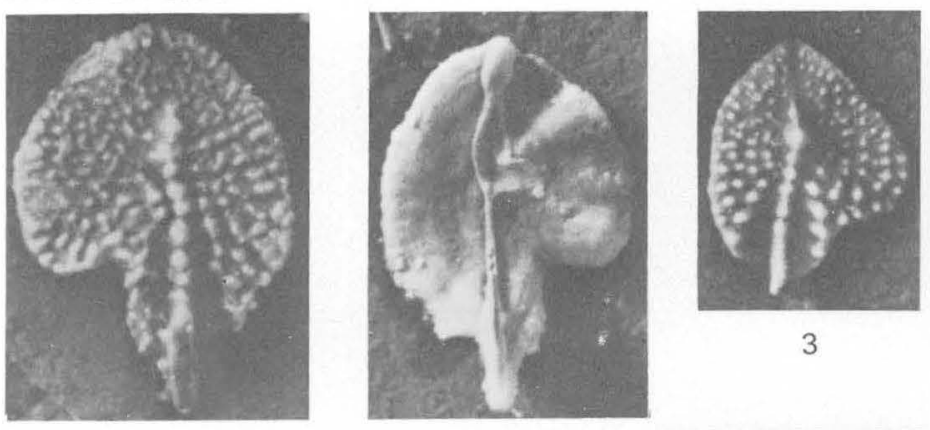

3

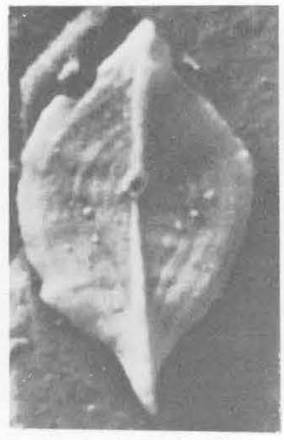

F

11

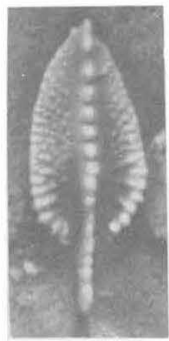

18

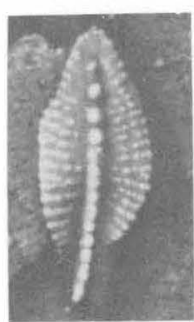

19

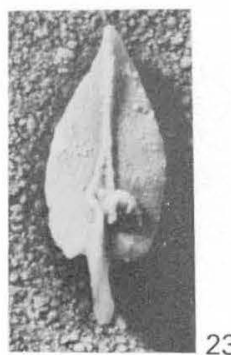

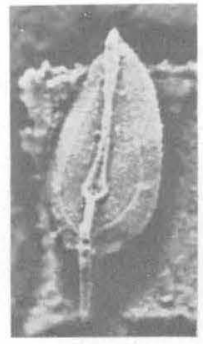

17

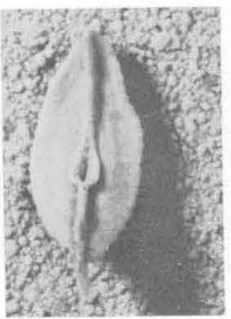

20

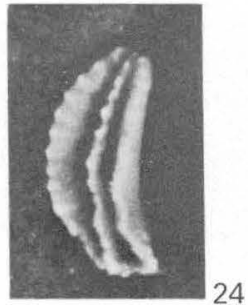

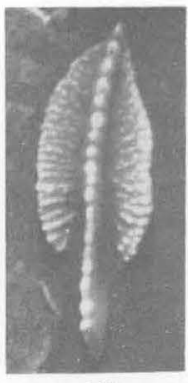

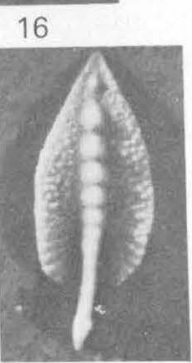

21

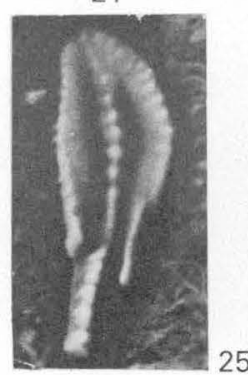

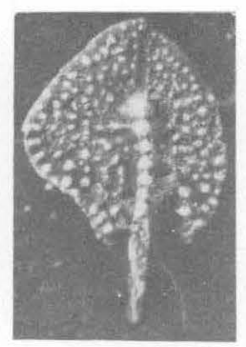

4

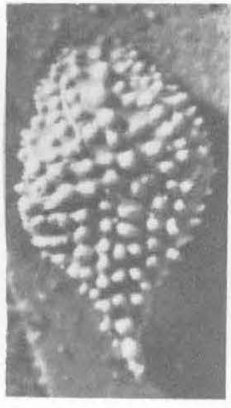

9

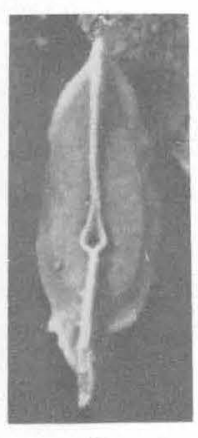

15

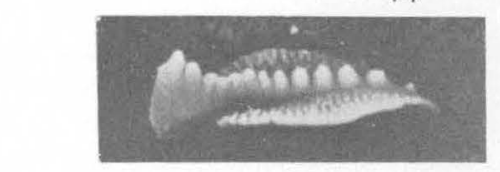

22
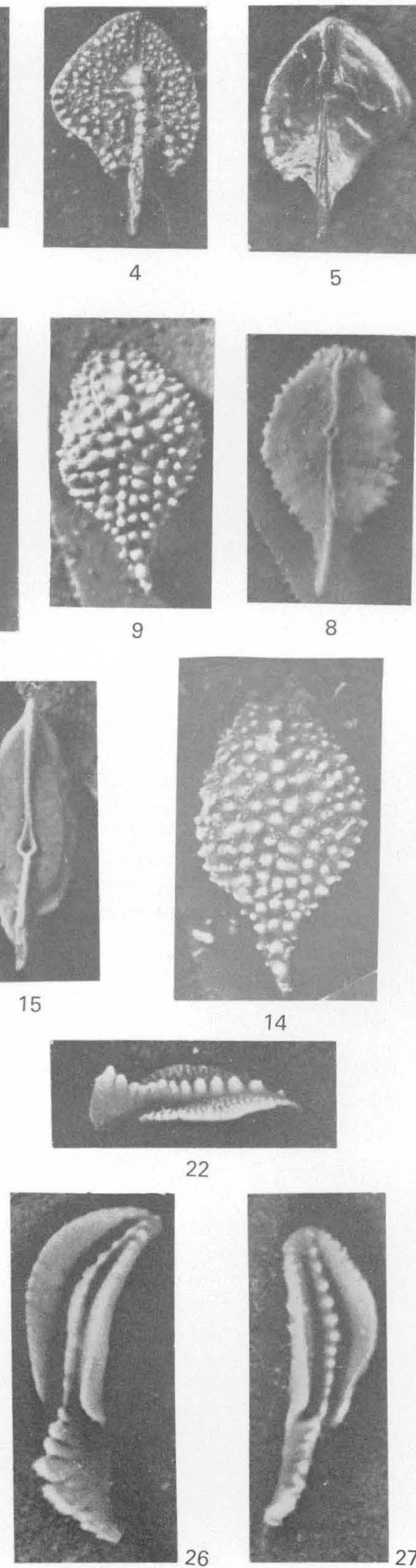

5

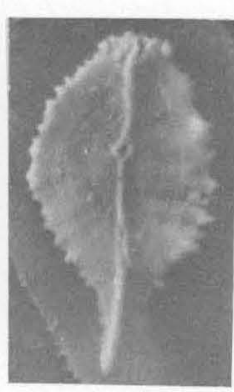

8

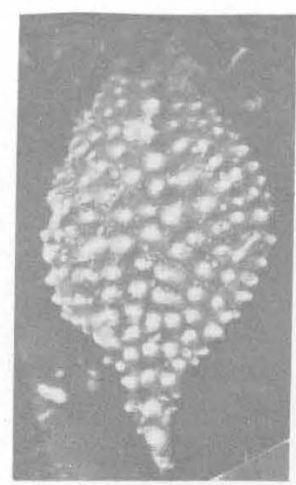

14

26

PROFESSIONAL PAPER 1032-B PLATE 6

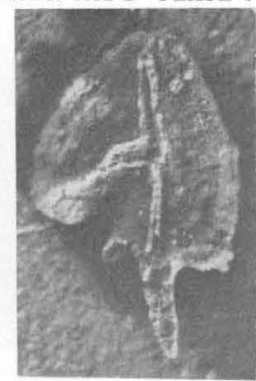

6

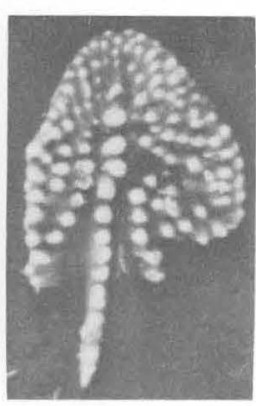

7

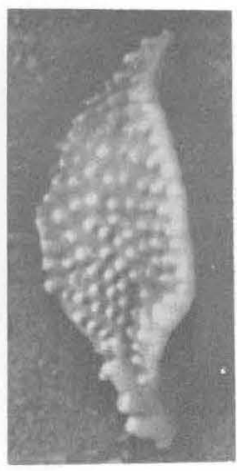

13

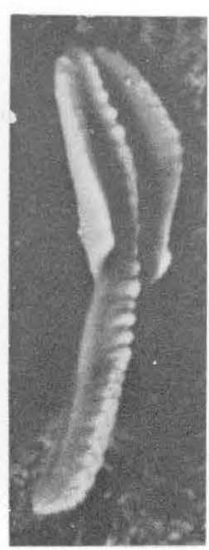

PALMATOLEPIS? AND POLYGNATHUS 


\section{PLATE 7}

[All specimens $\times 30$. Figs. 11 and 25 coated; others not coated]

Figures

$11,12,19-22$.
1-8. Polygnathus alatus Huddle (p. B25).

1. Aboral view, USNM 188674; USGS 4577-SD, Genundewa Limestone Member of Genesee Formation, Cayuga Creek (Dp-3). (See pl. 6, fig. 26 for oral view.)

2,3. Oral and aboral views, USNM 188679; USGS 6759-SD, Crosby Sandstone Member of Standish Formation as used by Torrey and others (1932), in Ithaca Member of Genesee Formation, Willow Grove (Py-14).

4,5. Aboral and lateral view, USNM 188675; USGS 4576-SD, Penn Yan Shale Member of Genesee Formation, Cayuga Creek (Dp-3). (Oral view pl. 6, fig. 28.) Note lack of white matter in denticles.

6, 7. Oral and lateral views, USNM 188682; USGS 8970-SD, Genundewa Limestone Member of Genesee Formation, Bethany Center (Ba-3).

8. Lateral view, USNM 188681; USGS 6759-SD, Crosby Sandstone Member of Standish Formation as used by Torrey and others (1932), in Ithaca Member of Genesee Formation, Willow Grove (Py-14).

9,10. Polygnathus alveoliposticus Orr and Klapper (p. B25).

9. Aboral view, USNM 188686; USGS 6733-SD, Tully Limestone, Gage Gully (Cd-12). Other views pl. 6, figs. 13,14 .

10. Lateral view, USNM 188683; USGS 6733-SD, Tully Limestone, Gage Gully (Cd-12). See pl. 6, figs. 10, 11, for other views. Note the thin, arched plate.

Polygnathus asymmetricus asymmetricus Bischoff and Ziegler (p. B25).

11, 12. Oral and aboral views of an immature specimen, USNM 188692; USGS 6754-SD, West River Shale Member of Genesee Formation, Chidsey Point (Py-7).

19-20. Oblique, lateral, and oral views, USNM 188688; USGS 6754-SD, West River Shale Member of Genesee Formation, Chidsey Point (Py-7).

21, 22. Oral and aboral views of a gerontic specimen, USNM 188691; USGS 6754-SD, West River Shale Member of Genesee Formation, Chidsey Point (Py-7).

13-15. Polygnathus asymmetricus unilabius n. subsp. (p. B26).

Oral, aboral, and lateral views, USNM 188805; USGS 6754-SD, West River Shale Member of Genesee Formation, Chidsey Point $(\mathrm{Py}-7)$. Note thin plate and shape of basal cavity.

16-18. Polygnathus ectypus Huddle

Lateral, aboral and oral views, USNM 188734; USGS 6774-SD, Penn Yan Shale Member of Genesee Formation, Hubbard quarry (Gen-2). Note coarse nodes on a small immature specimen.

23-26. Polygnathus asymmetricus ovalis Ziegler and Klapper

23,24. Oral and aboral views, USNM 188733; USGS 8970-SD, Genundewa Limestone Member of Genesee Formation, Bethany Center $(\mathrm{Ba}-3)$. Note conodont basal plate.

25. Same specimen coated to show distribution of fine nodes.

26. Oblique view to show clear denticles and coarse nodes, USNM 188737; USGS 4577-SD, Genundewa Limestone Member of Genesee Formation, Cayuga Creek (Dp-3). 
GEOLOGICAL SURVEY
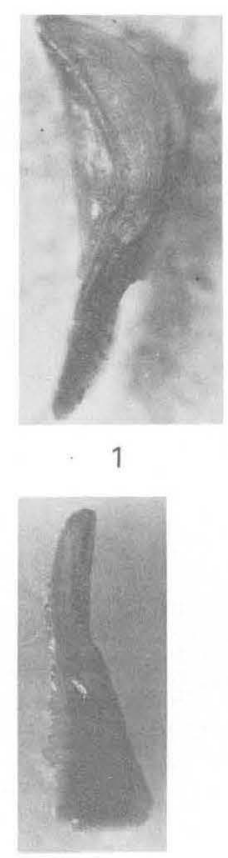

8

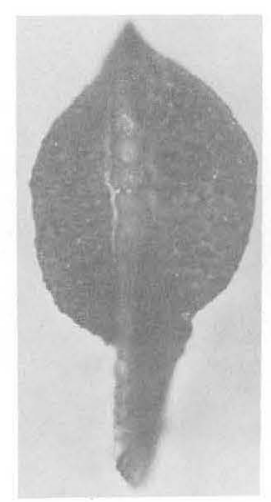

20

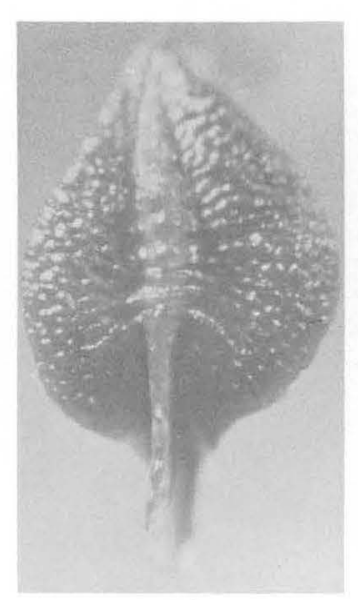

21

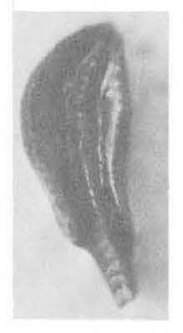

2

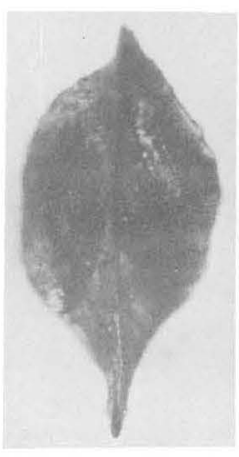

9

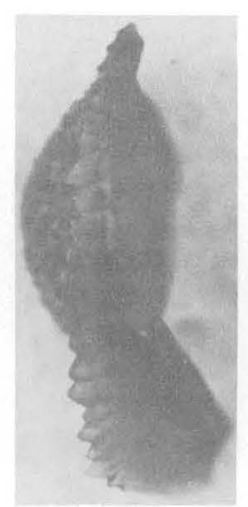

19

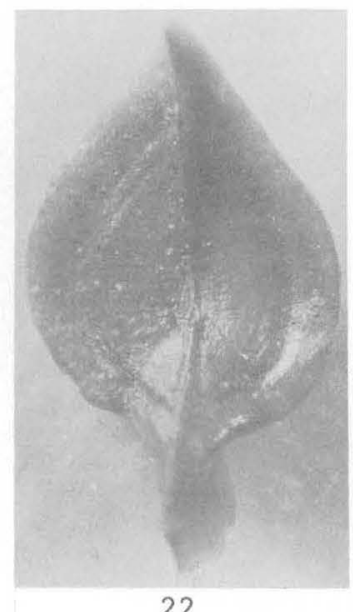

22
.

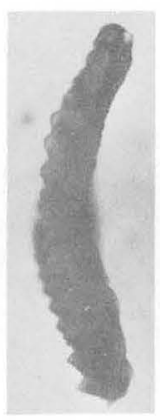

10

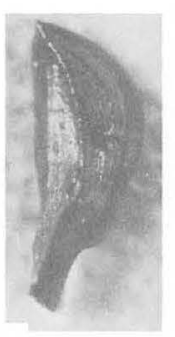

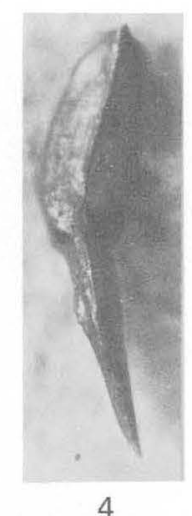

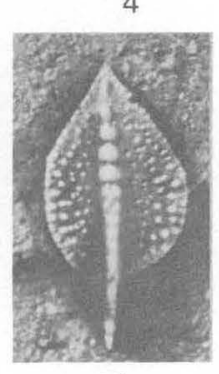

11

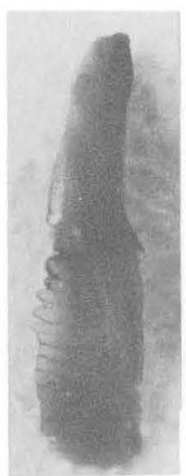

5

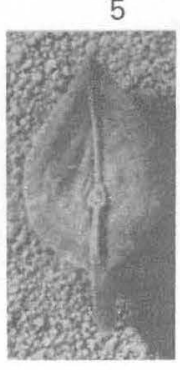

12
PROFESSIONAL PAPER 1032-B PLATE 7

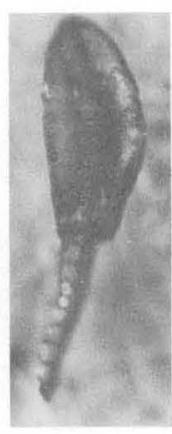

6

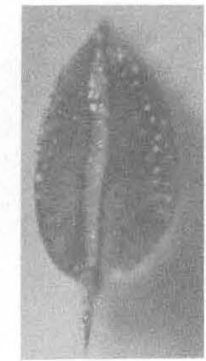

13

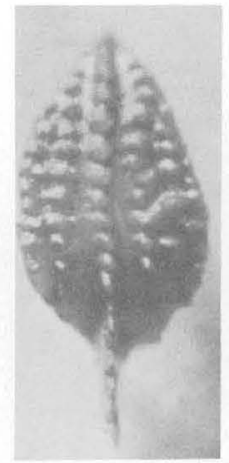

18
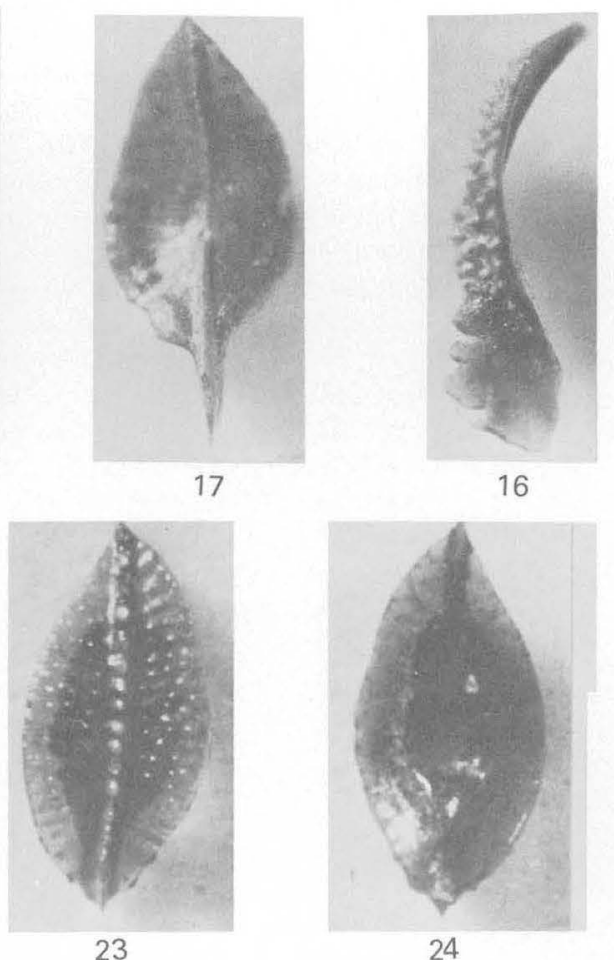

16

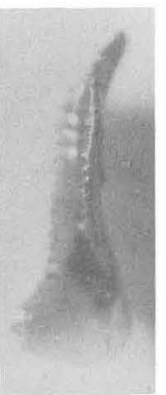

15

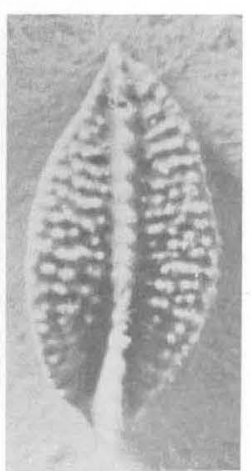

25 


\section{PLATE 8}

[Figs. $6,7,15,16 \times 35 ;$ all others $\times 30$. All specimens coated except fig. 13]

Figures 1-3, 5-7,15,16. Polygnathus asymmetricus asymmetricus Bischoff and Ziegler (p. B25).

1. Oral view of a large specimen, USNM 188689; USGS 6791-SD, upper Ithaca Member of Genesee Formation, Coy Glen (I-3).

2,3. Oral and aboral views, USNM 188740; USGS 4538-SD, North Evans Limestone of Rickard (1964), Eighteenmile Creek (Ed-1).

5. Aboral view USNM 188688; USGS 6754-SD, upper West River Shale Member of Genesee Formation, Chidsey Point (Py-7).

6, 7. Oblique-oral and oral views, USNM 188693; USGS 6754-SD, upper West River Shale Member of Genesee Formation, Chidsey Point (Py-7).

15. Lateral view showing carina. Second denticle from anterior end of blade has a broken tip. USNM 188687; USGS 6754-SD, upper West River Shale Member of Genesee Formation, Chidsey Point (Py-7).

16. Oral view gerontic specimen, USNM 188690; USGS 6754-SD, upper West River Shale Member of Genesee Formation, Chidsey Point (Py-7).

4, 8, 9, 11, 12,14. Polygnathus asymmetricus unilabius n. subsp. (p. B26).

4. Aboral view, USNM 188807; USGS 6754-SD, upper West River Shale Member of Genesee Formation, Chidsey Point (Py-7).

8,9. Oral and aboral views of the holotype, USNM 188808; USGS 6754-SD, upper west River Shale Member of Genesee Formation, Chidsey Point (Py-7).

11,12. Oral and aboral views of a large specimen, USNM 188806; USGS 6754-SD, upper West River Shale Member of Genesee Formation, Chidsey Point (Py-7).

14. Oral view, USNM 188804; USGS 6754-SD, upper West River Shale Member of Genesee Formation, Chidsey Point $(\mathrm{Py}-7)$.

10,13. Polygnathus asymmetricus ovalis Ziegler and Klapper (p. B26).

10,13. Aboral and oral views, USNM 188736; USGS 4577-SD, Genundewa Limestone Member of Genesee Formation, Cayuga Creek (Dp-3). 
GEOLOGICAL SURVEY

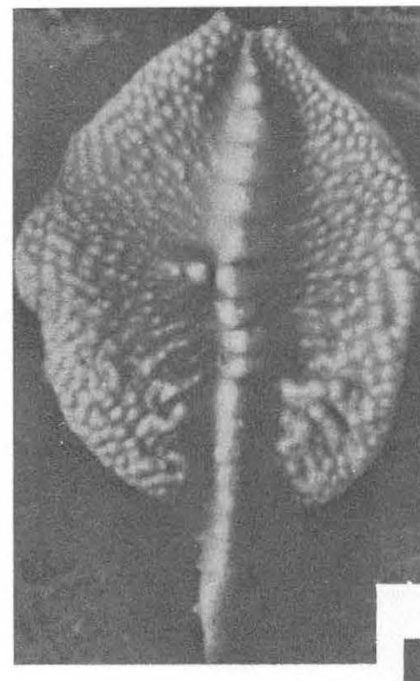

1

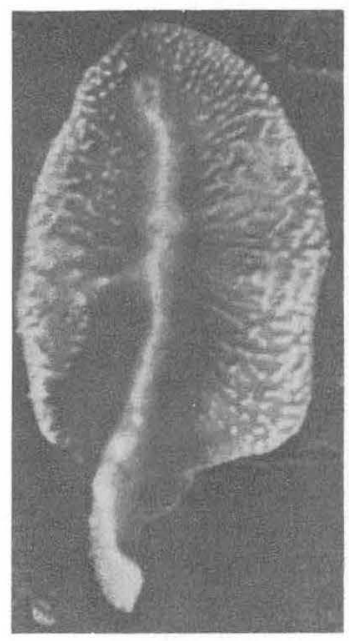

11

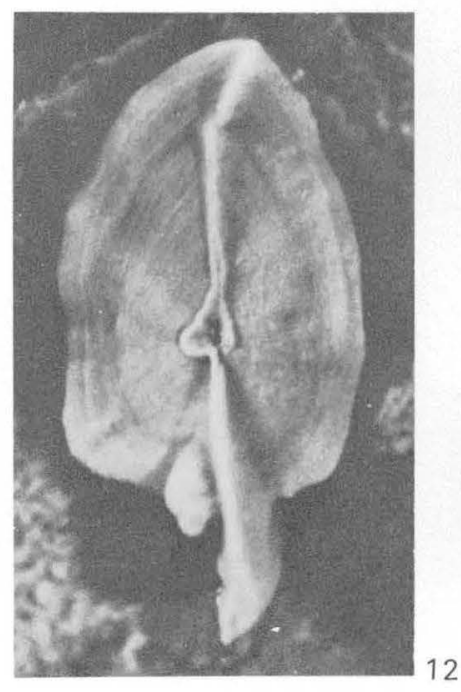

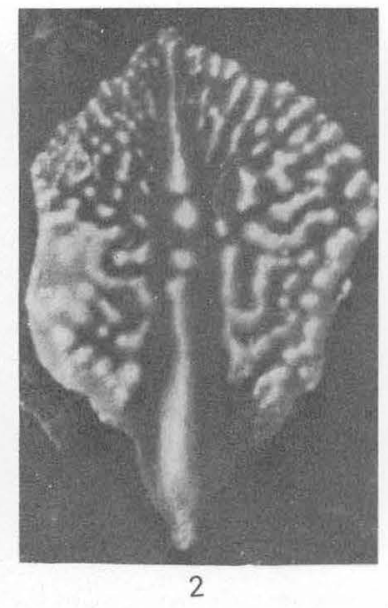

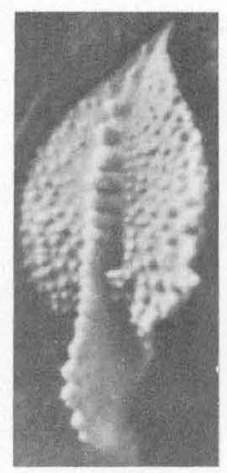

6

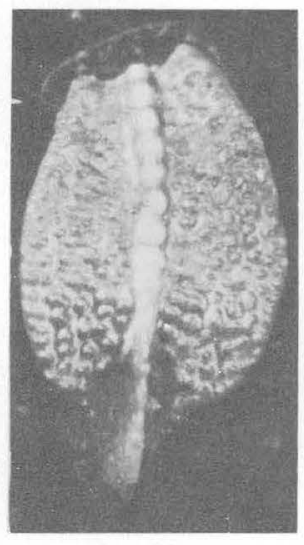

13

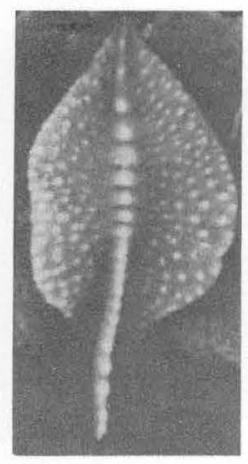

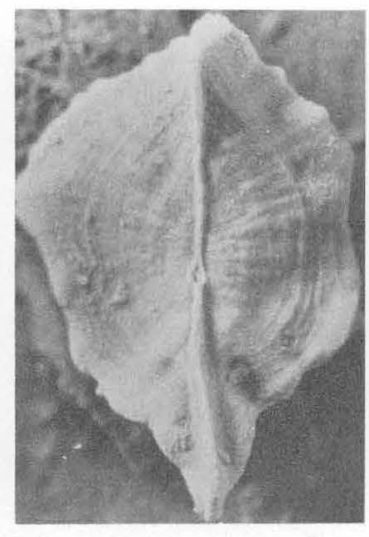

3
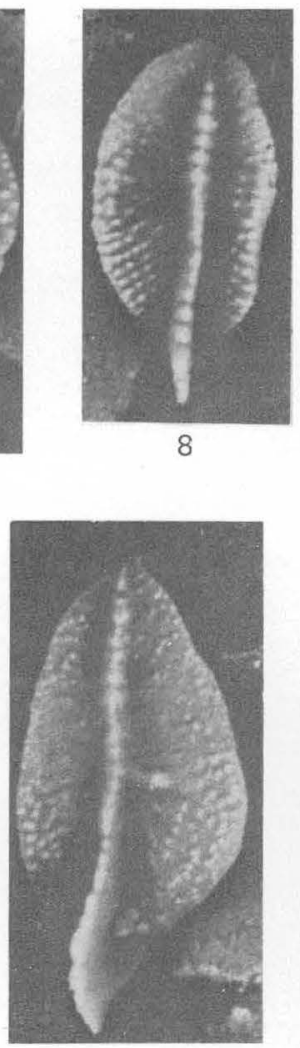

14

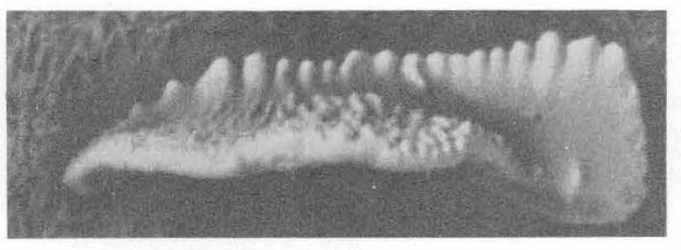

15

POLYGNATHUS
PROFESSIONAL PAPER 1032-B PLATE 8
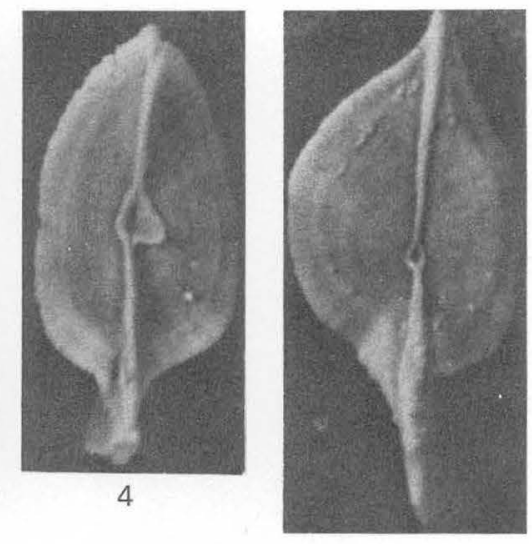

5
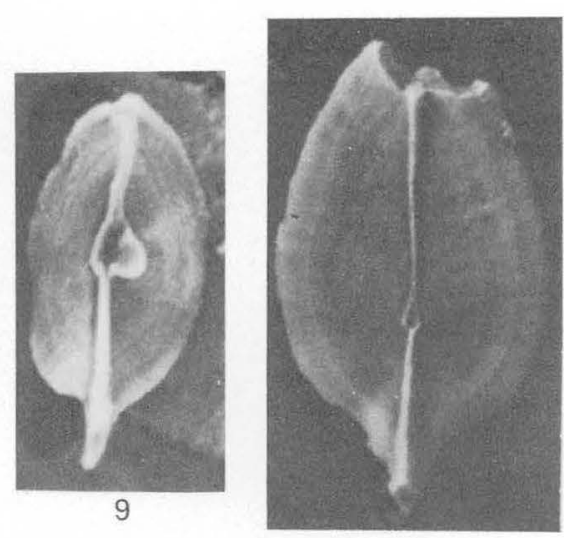

10

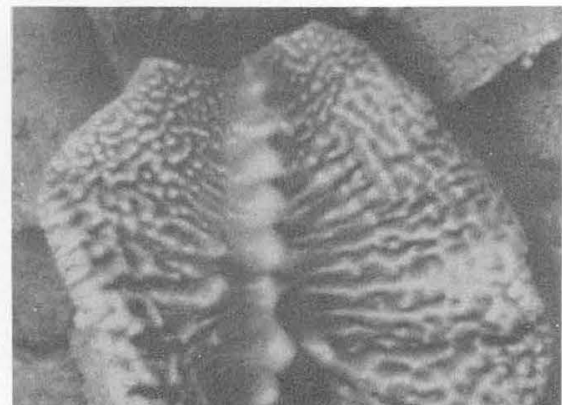

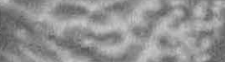

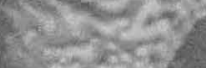

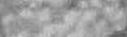

5eteres
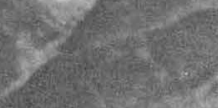


\section{PLATE 9}

[All specimens $\times 30$ except figs. 20-22 $\times 35$. Specimens coated except figs. $1-3,8,10,15,19,24]$

Figures 1-3, 6-10. Polygnathus ectypus Huddle (p. B30).

1-3. Aboral, oral, and lateral views, USNM 188730; USGS 7619-SD, Genundewa Limestone Member of Genesee Formation, Clover Bank quarry (Ed-2). Note coarse nodes, small basal plate, and thin plate.

6,7. Aboral and oral view, USNM 188732; USGS 8970-SD, Genundewa Limestone Member of Genesee Formation, Bethany Center (Ba-3). Note basal plate and coarse nodes.

8-10. Oblique, oral, and aboral views, USNM 188735; USGS 4577-SD, Genundewa Limestone Member of Genesee Formation, Bethany Center ( $\mathrm{Ba}-3)$. Nate thin plate, coarse nodes, and short free blade.

4, 5. Polygnathus sp. [not discussed in text].

4, 5. Aboral and oral views, USNM 188739; USGS 6774-SD, Penn Yan Shale Member of Genesee Formation, Hubbard quarry, Lively Run (Gen-2).

11-19. Polygnathus cristatus Hinde (p. B28).

11,12. Oral and aboral views, USNM 188728; USGS 6766-SD, Crosby Sandstone Member of Standish Formation as used by Torrey and others (1932), in Ithaca Member of Genesee Formation, Tommy Run (Ov-21). Shows typical basal cavity and nodes.

13-15. Oral, aboral, and oblique views, USNM 188729; USGS 6756-SD, Crosby Sandstone Member of Standish Formation as used by Torrey and others (1932), in Ithaca Member of Genesee Formation, Sunset Point (Py-15). Note lack of white matter.

16. Oral view, USNM 188725; USGS 6759-SD, Crosby Sandstone Member of Standish Formation as used by Torrey and others (1932), in Ithaca Member of Genesee Formation, Willow Grove (Py-14).

17-19. Oral, aboral, and lateral views, USNM 188724; USGS 6756-SD, Crosby Sandstone Member of Standish Formation as used by Torrey and others (1932), in Ithaca Member of Genesee Formation, Sunset Point (Py-15). Note large free blade, high denticle at midpoint, lack of white matter, and anterior notch in outer platform.

20-25. Polygnathus collieri n. sp. (p. B27).

20-22. Oral, oblique, and aboral views, USNM 188714; USGS 6754-SD, West River Shale Member of Genesee Formation, Chidsey Point $(\mathrm{Py}-7)$.

23, 24. Oral and oblique views, USNM 188715; USGS 6754-SD, West River Shale Member of Genesee Formation, Chidsey Point (Py-7). Note diffuse white matter in tips of denticles.

25. Oral view, USNM 188713; USGS 6754-SD, West River Shale Member of Genesee Formation, Chidsey Point $(\mathrm{Py}-7)$. 
GEOLOGICAL SURVEY
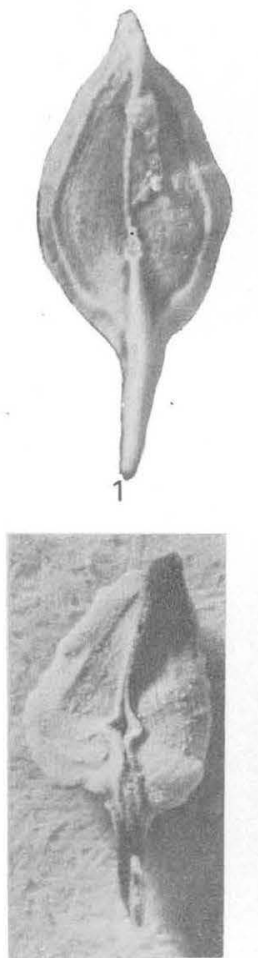

12

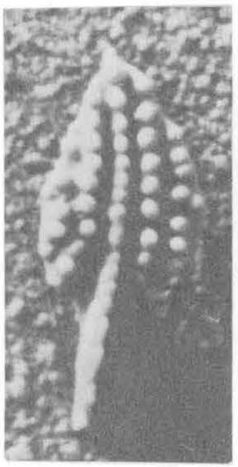

13

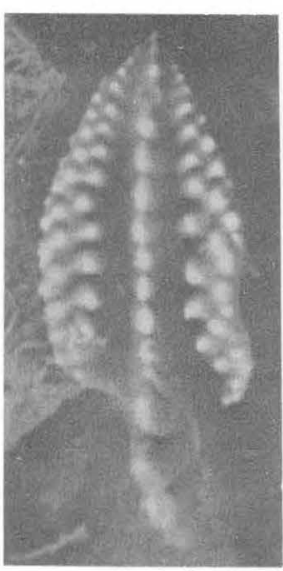

20
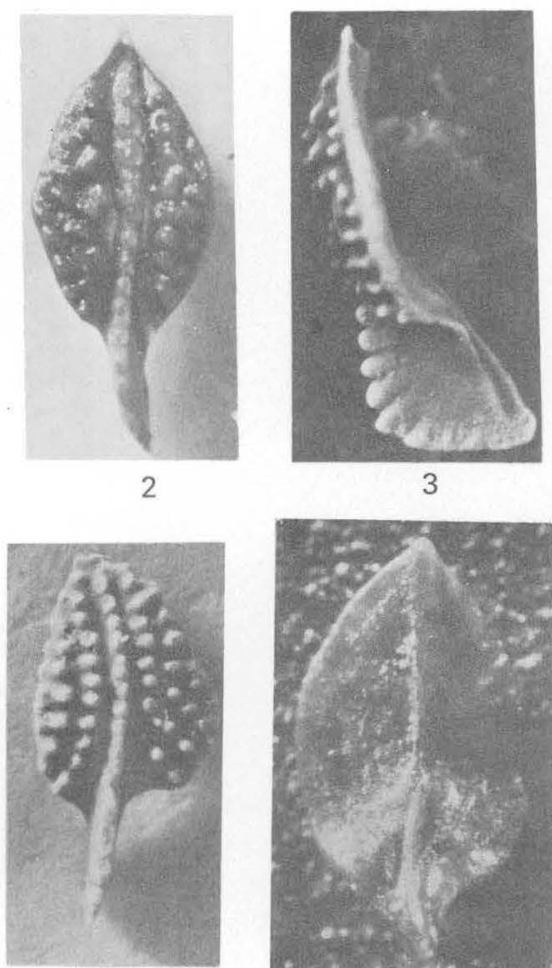

11

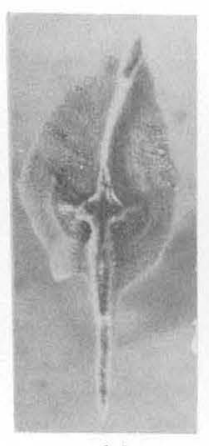

14

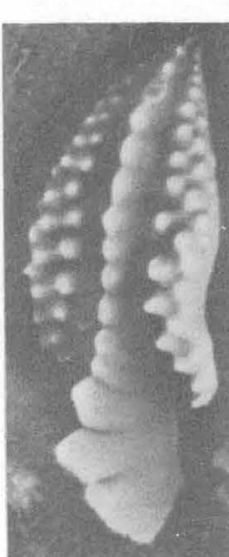

21

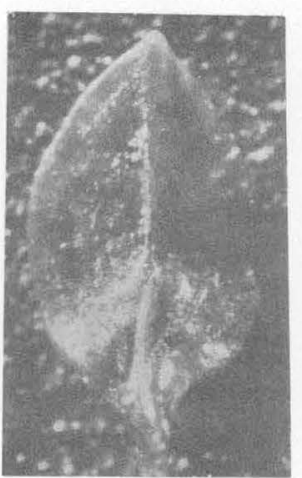

10

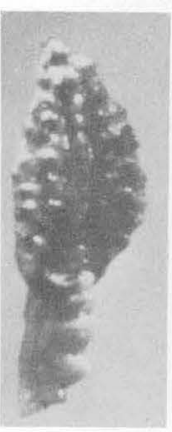

15

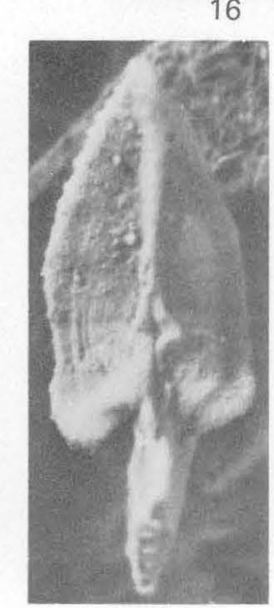

22
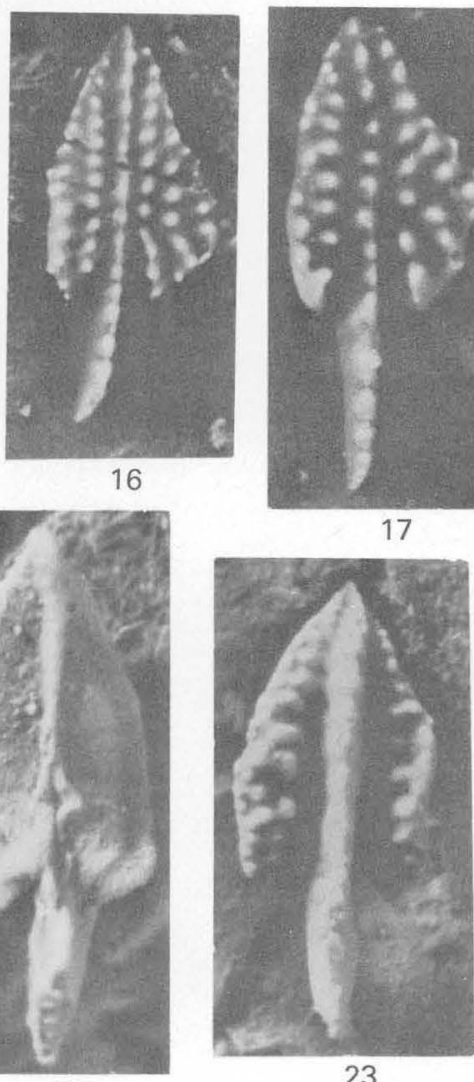

23

9

17
PROFESSIONAL PAPER 1032-B PLATE 9
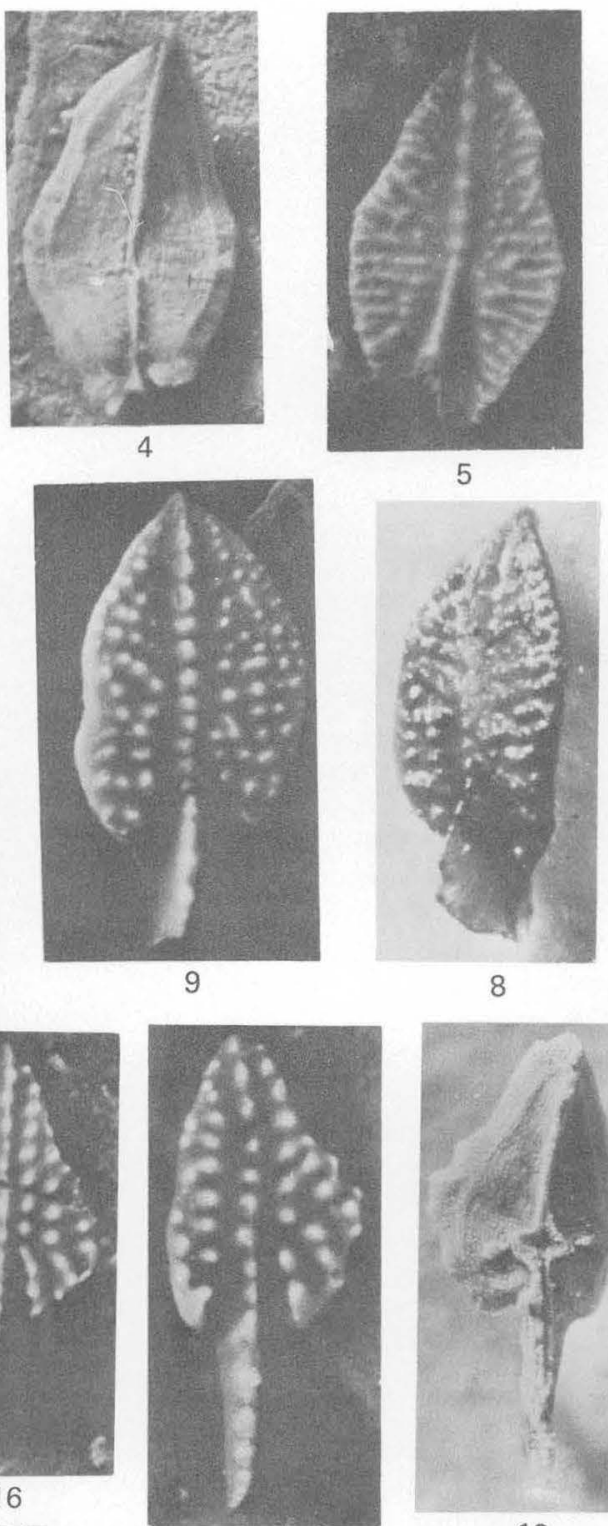

8

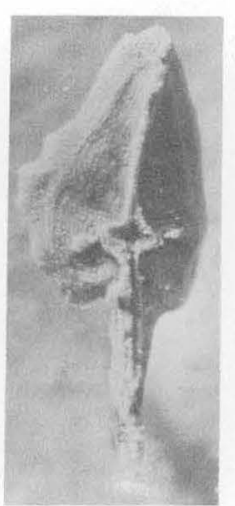

18

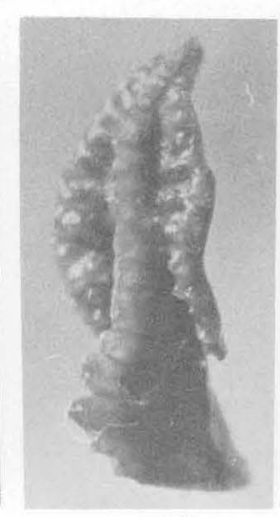

24

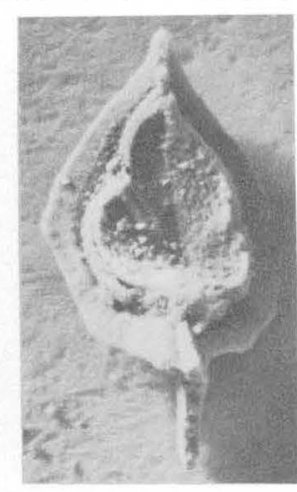

6

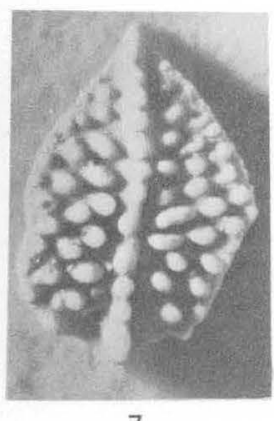

7

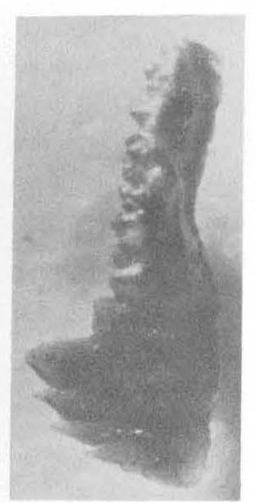

19

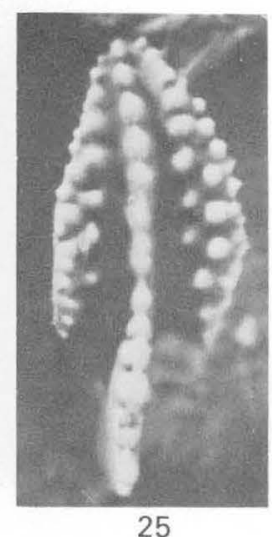

POLYGNATHUS 


\section{PLATE 10}

[All specimens $\times 30$. Specimens in figs. 4, 7, 9, 12-21 uncoated; others coated]

Figures 1-18. Polygnathus cristatus Hinde (p. B28).

Specimens shown in figs. $1,2,6,9,10$ questionably referred to species.

1,2. Oral and aboral views, USNM 188719; USGS 4538-SD, Leicester Marcasite Member of Moscow Formation of Sutton (1951), Eighteenmile Creek (Ed-1). Note large basal pit and rostral ridge.

3-5. Oral, lateral, and aboral views, USNM 188720; USGS 4538-SD, Leicester Marcasite Member of Moscow Formation of Sutton (1951), Eighteenmile Creek (Ed-1). Note sharp bend in posterior part of carina. This specimen has a little white matter in blade denticles.

6. Aboral view, USNM 188718; USGS 4538-SD, Leicester Marcasite Member of Moscow Formation of Sutton (1951), Eighteenmile Creek (Ed-1). Like Ancyrodella rotundiloba s.s. but has rostral ridges.

7,8. Aboral and oral views, USNM 188726; USGS 6759-SD, Crosby Sandstone Member of Standish Formation as used by Torrey and others (1932), in Ithaca Member of Genesee Formation, Willow Grove $(\mathrm{Py}-14)$. Note attached basal plate that is similar to basal plate of Ancyrodella.

9, 10. Aboral and oral views, USNM 188727; USGS 6759-SD, Crosby Sandstone Member of Standish Formation as used by Torrey and others (1932), in Ithaca Member of Genesee Formation, Willow Grove (Py-14).

11,12. Oral and aboral views, USNM 188723; USGS 6756-SD, Crosby Sandstone Member of Standish Formation as used by Torrey and others (1932), in Ithaca Member of Genesee Formation, Sunset Point $(\mathrm{Py}-15)$.

13-15. Oral, aboral, and lateral view of an uncoated small (young) specimen showing lack of white matter and regular rows of nodes, USNM 188721; USGS 6756-SD, Crosby Sandstone Member of Standish Formation as used by Torrey and others (1932), in Ithaca Member of Genesee Formation, Sunset Point (Py-15).

16-18. Oral, aboral, and lateral views, USNM 188722; USGS 6756-SD, Crosby Sandstone Member of Standish Formation as used by Torrey and others (1932), in Ithaca Member of Genesee Formation, Sunset Point (Py-15).

19-21. Polygnathus sp. [not discussed in text; refer to tables].

Aboral, lateral, and oral views, USNM 188769; USGS 4569-SD, Leicester Marcasite Member of Moscow Formation of Sutton (1951), Cayuga Creek (Dp-3). This small immature specimen has a thin plate, small pit, alined nodes like $P$. asymmetricus ovalis, but shape of plate and uneven margins are like $P$. cristatus.

22. Polygnathus collieri n. sp. (p. B27).

Oral view, USNM 188717; USGS 6754-SD, West River Shale Member of Genesee Formation, Chidsey Point (Py-7). 


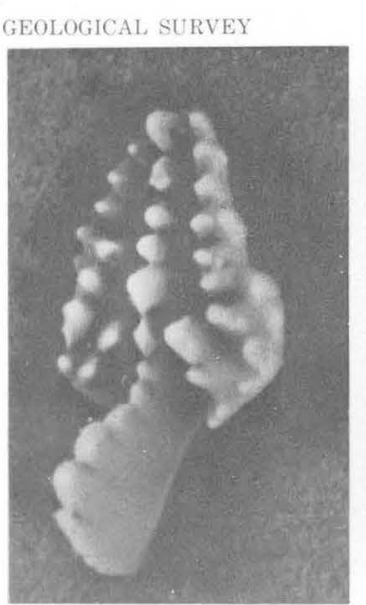

1

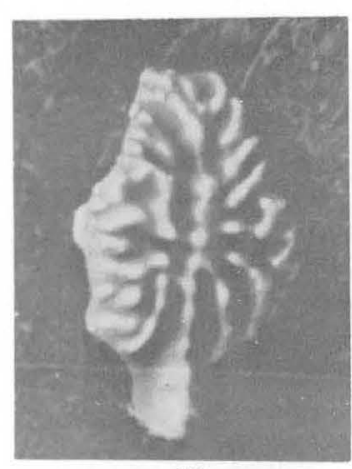

10

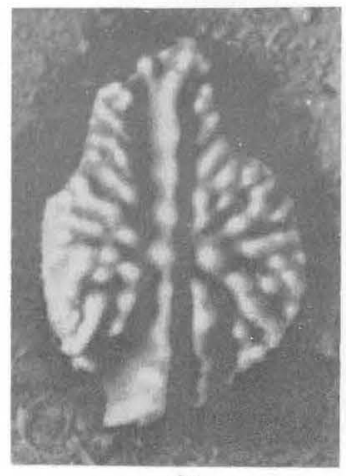

11

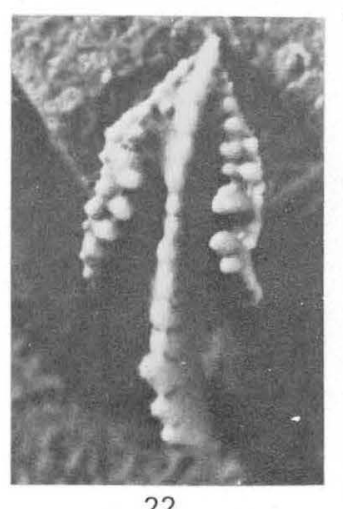

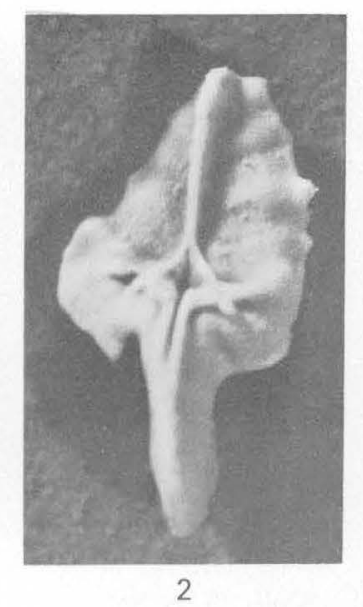

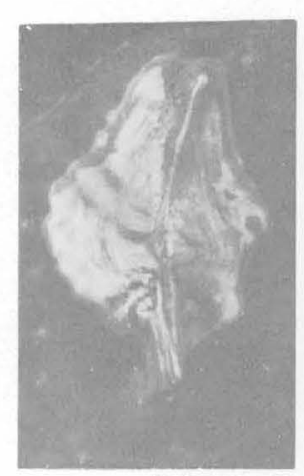

9

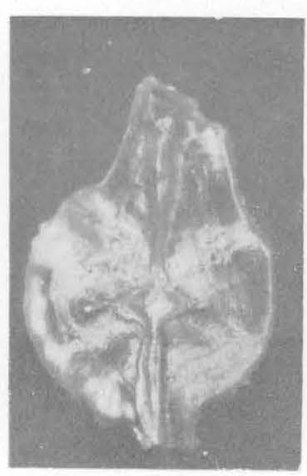

12

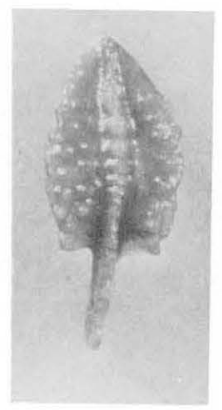

21
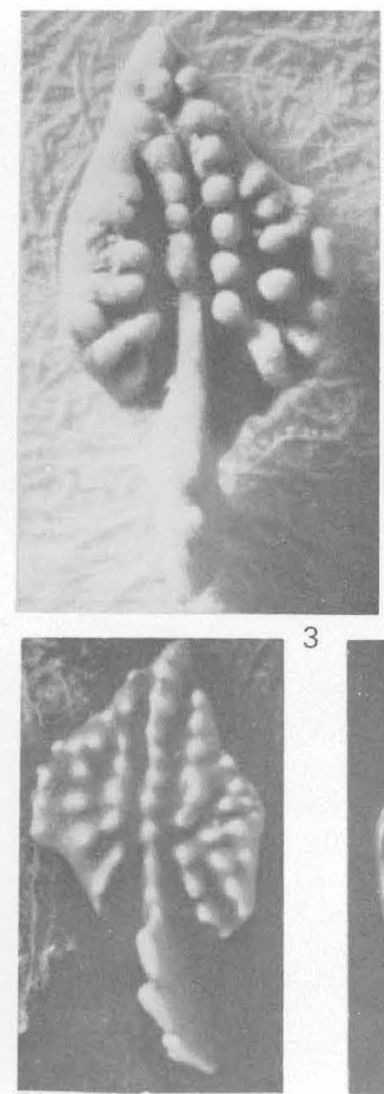

8

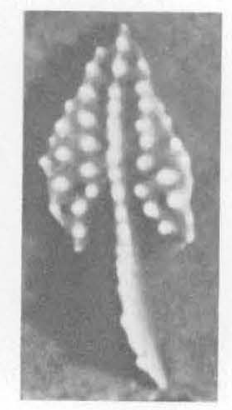

13

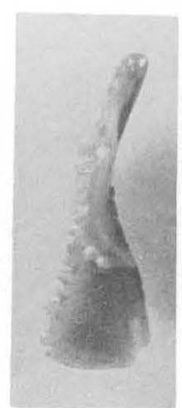

20

14

19
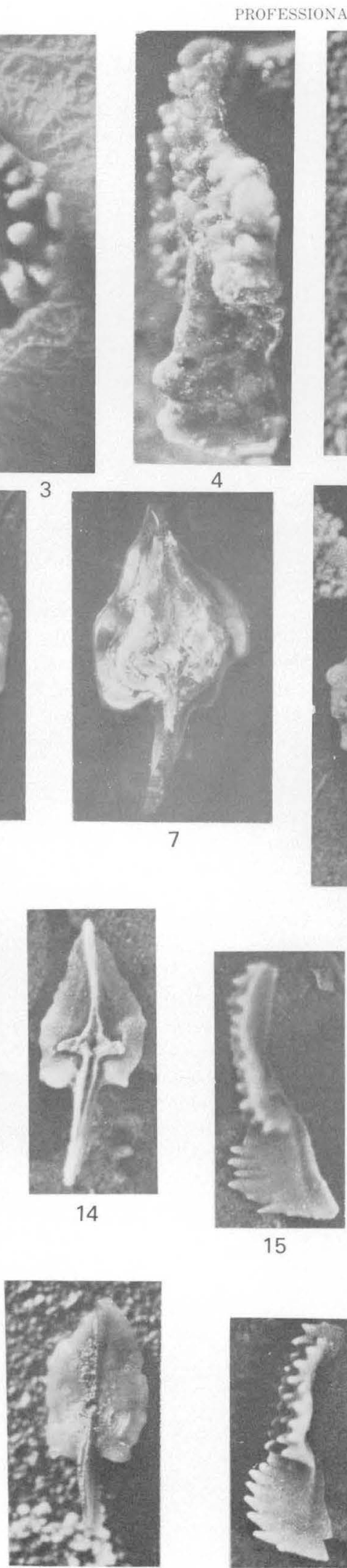
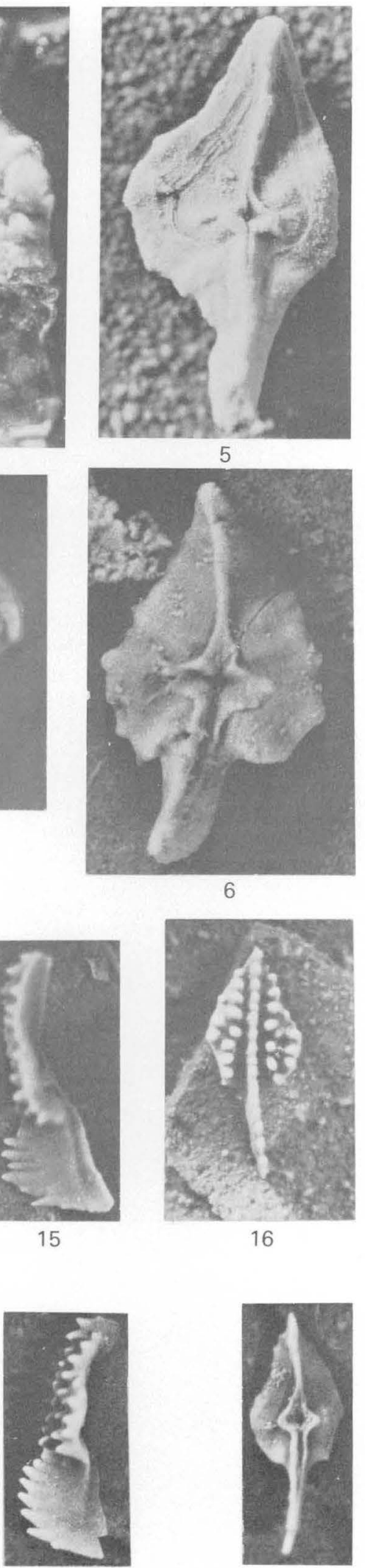

18

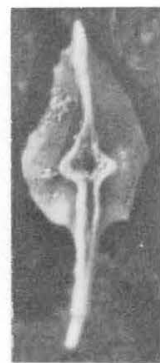

17

POLYGNATHUS 


\section{PLATE 11}

[Figs. 1, 4, 8, 9, $14 \times 35$; others $\times 30$. Figs. 5-7, 11, 13 uncoated; other coated]

FIgURes 1-4. Polygnathus collieri n. sp. (p. B27).

1. Oral view, USNM 188708; USGS 4577-SD, Genundewa Limestone Member of Genesee Formation, Cayuga Creek (Dp-3).

2,3. Oral and aboral views, USNM 188709; USGS 4577-SD, Genundewa Limestone Member of Genesee Formation, Cayuga Creek (Dp-3).

4. Oral view, USNM 188706; USGS 4577-SD, Genundewa Limestone Member of Genesee Formation, Cayuga Creek (Dp-3).

5-7. Polygnathus peracutus Bryant (p. B31).

Oral, aboral, and lateral views, USNM 188761; USGS 4553-SD, Genundewa Limestone Member of Genesee Formation, Cazenovia Creek (Dp-1). Characteristic square anterior platform margin.

8-14. Polygnathus tuberculatus Hinde (p. B32).

8,9. Oral and aboral views, USNM 188801; USGS 7622-SD, North Evans Limestone of Rickard (1964), Eighteenmile Creek (Ed-1).

10. Oral view, USNM 188742; USGS 7622-SD, North Evans Limestone of Rickard (1964), Eighteenmile Creek (Ed-1). Note complete free blade. The basal plate present on this specimen.

11. Oral view, USNM 188743; USGS 4569-SD, Leicester Marcasite Member of Moscow Formation, of Sutton (1951), Cayuga Creek (Dp-3).

12,13. Oral and aboral views, USNM 188744; USGS 4538-SD, Leicester Marcasite Member of Moscow Formation of Sutton (1951), Eighteenmile Creek (Ed-1).

14. Aboral view, USNM 188800; USGS 4538-SD, Leicester Marcasite Member of Moscow Formation of Sutton (1951), Eighteenmile Creek (Ed-1).

15-18. Polygnathus? caelatus Bryant (p. B27).

15,16. Oral and oblique-lateral views of a large specimen, USNM 188697; USGS 7622-SD, North Evans Limestone of Rickard (1964), Eighteenmile Creek (Ed-1).

17,18. Oral and aboral views, young specimen, USNM 188695; USGS 6733-SD, Tully Limestone, Gage Gully (Cd-12). 

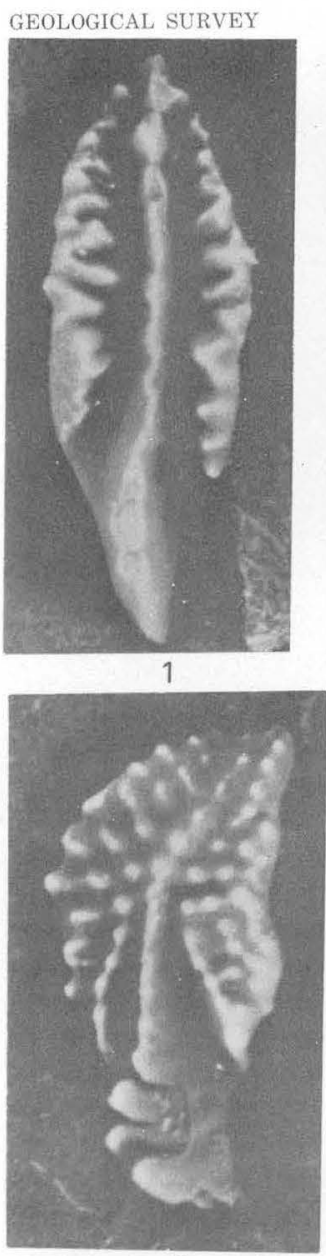

8

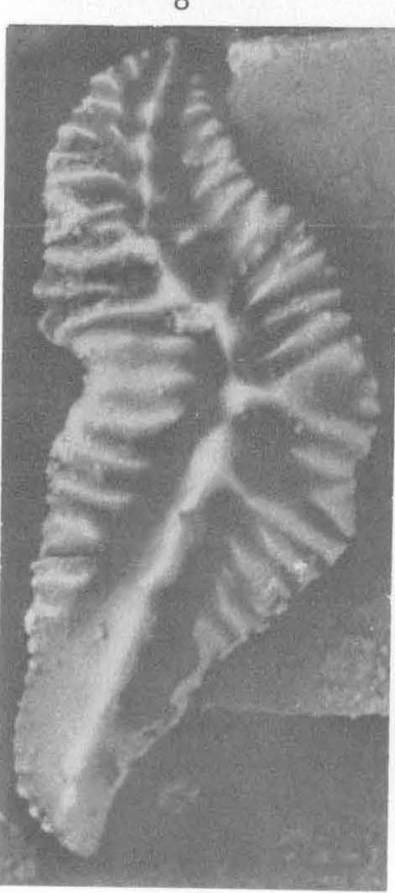

15

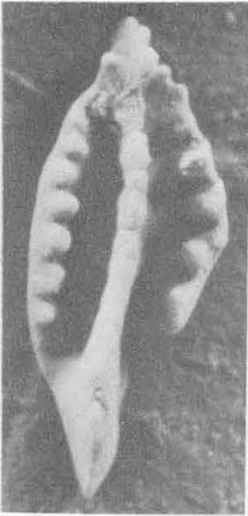

2
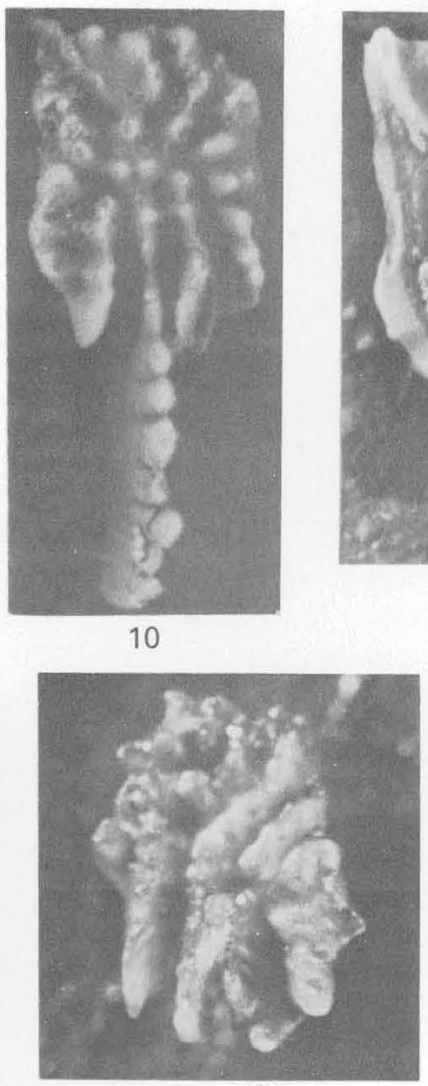

12

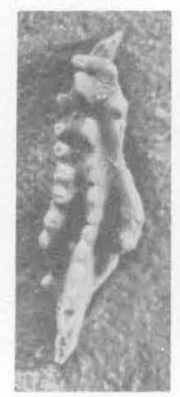

17

3
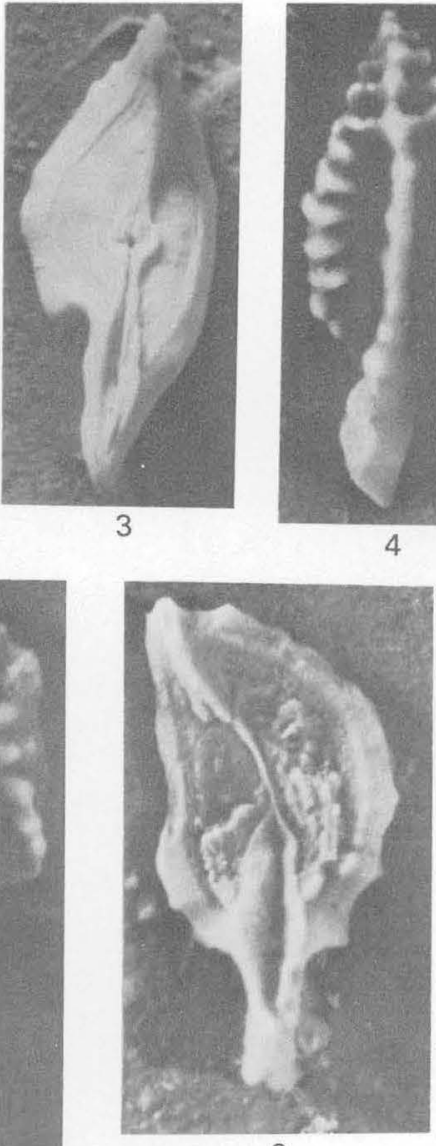

9

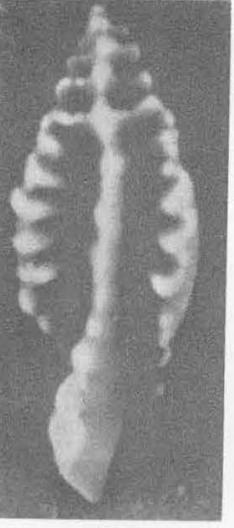

4
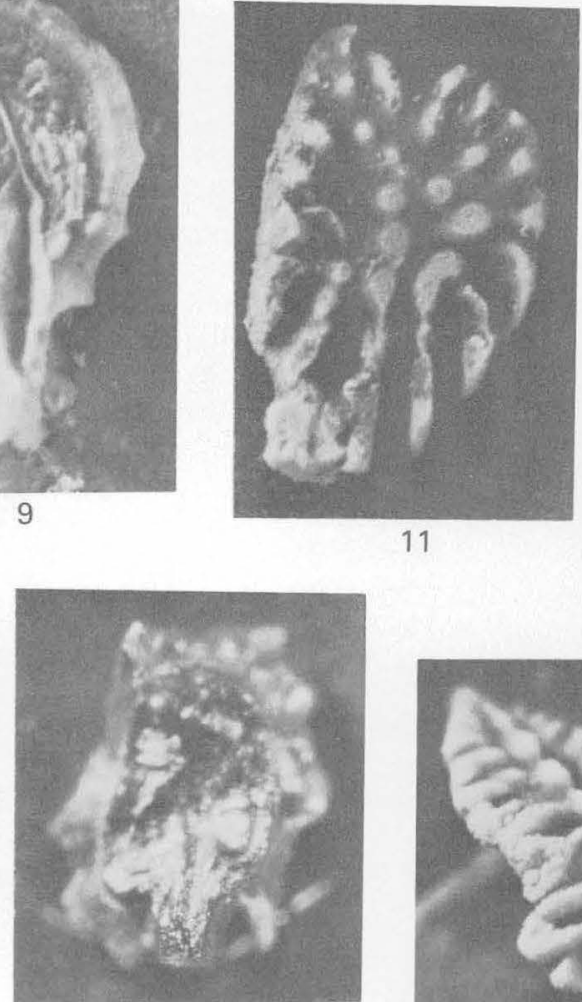

13

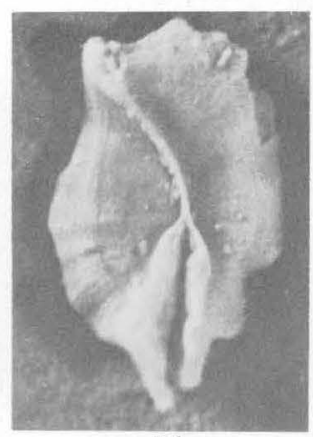

14

18
5

11
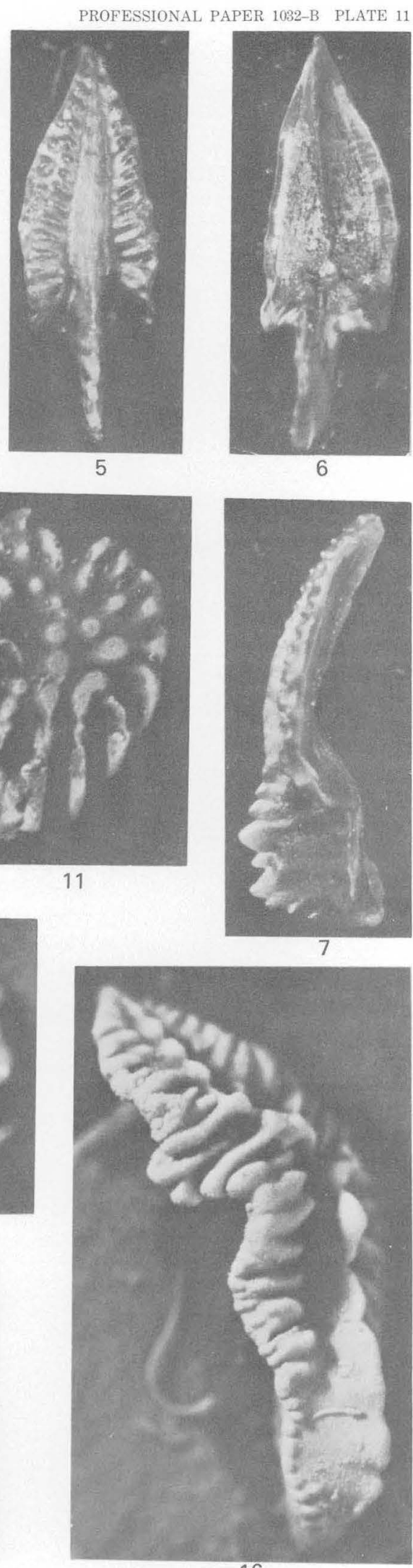

16 


\section{PLATE 12}

[All figures $\times 30$. Figs. 13-15, 22, 23 coated, others uncoated]

1-3. Polygnathus collieri n. sp. (p. B27).

Lateral, oral, and aboral views of holotype, USNM 188707; USGS 4577-SD, Genundewa Limestone Member of Genesee Formation, Cayuga Creek (Dp-3).

4-6. Polygnathus pennatus Hinde (p. B31).

Oral, aboral, and lateral views, USNM 188699; USGS 6727-SD, Geneseo Shale Member of Genesee Formation, Hubbard quarry Lively Run (Gen-2). This is a large gerontic specimen. Note that it lacks the adcarinal troughs of $P$. collieri.

7-18, 22-24. Polygnathus? caelatus Bryant (p. B27).

7-9. Oral, aboral, and oblique views, USNM 188711; USGS 4577-SD, Genundewa Limestone Member of Genesee Formation, Cayuga Creek (Dp-3).

10,11. Oral and aboral views, USNM 188694; USGS 6777-SD, Penn Yan Shale Member of Genesee Formation, north of Taughannock Falls (Gen-4).

12,13. Oral and aboral views, USNM 188710; USGS 6733-SD, Tully Limestone, Gage Gully (Cd-12).

14,15. Oral and aboral views, USNM 188698; USGS 4538-SD, Leicester Marcasite Member of Moscow Formation of Sutton (1951), Eighteenmile Creek (Ed-1).

16-18. Oral, aboral, and lateral views, USNM 188712; Bryant's Colln., North Evans Limestone of Rickard (1964), Eighteenmile Creek (Ed-1).

22,23. Oral and aboral views, USNM 188696; USGS 4538-SD, Leicester Marcasite Member of Moscow Formation of Sutton (1951), Eighteenmile Creek (Ed-1). Gerontic specimen.

24. Lateral view, USNM 188709; USGS 4577-SD, Genundewa Limestone Member of Genesee Formation, Cayuga Creek (Dp-3). See pl. 11, figs. 2, 3, for other views.

19-21. Polygnathus tuberculatus Hinde (p. B32).

Aboral, oral, and oblique views, USNM 188802; USGS 3984-SD, Leicester Marcasite Member of Moscow Formation of Sutton (1951), Pike Creek (SC-1). Note denticles lack white matter. 


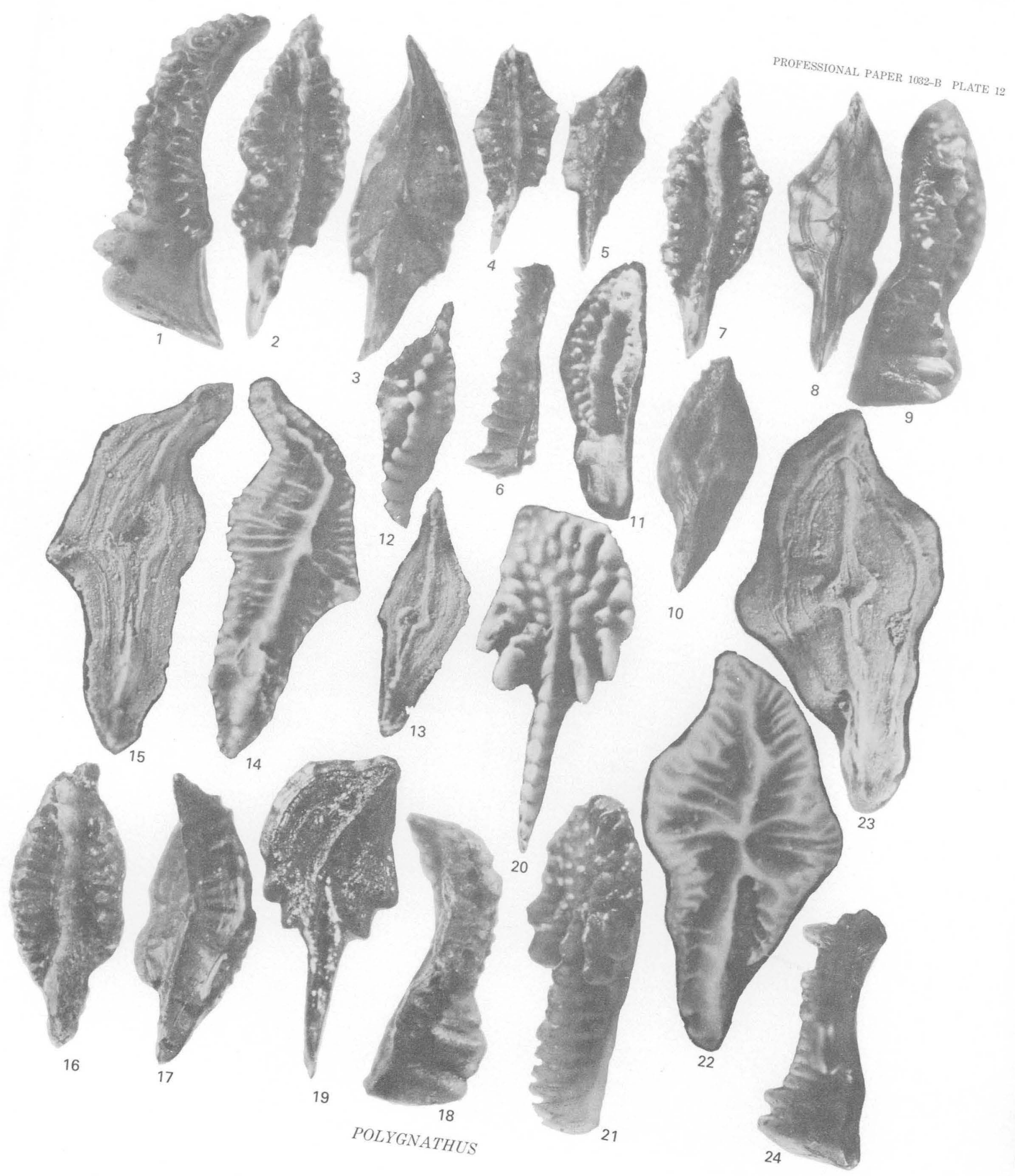




\section{PLATE 13}

[All figures $\times$ 30. Figs. 12, 13, $16 \cdot$ uncoated; others coated. All specimens figured by Bryant (1921) from North Evans Limestone of Rickard (1964), Eighteenmile Creek $(\mathrm{Ed}-1)$ ]

Figures 1-6,12,13. Polygnathus? caelatus Bryant. Bryant's syntypes (p. B27).

1. Oral view of a large specimen with a broken posterior tip, USNM 135048 (Bryant, 1921, pl. 13, fig. 5).

2. Posterior part of a broken plate (Bryant 1921, pl. 13, fig. 13), USNM 135052.

3. Oral view of a weathered specimen (Bryant, 1921, pl. 13, fig. 3), USNM 135047.

4. Oral view, USNM 135051 (Bryant, 1921, pl. 13, fig. 12).

5. Oral view, USNM 135049 (Bryant 1921, pl. 13, fig. 8).

6,12,13. Aboral, oral, and lateral views of the lectotype, USNM 135046 (Bryant, 1921, pl. 13, fig. 2).

7,8. Polygnathus peracutus Bryant (p. B31).

Oral and aboral views of the holotype, USNM 135036 (Bryant, 1921, pl. 10, fig. 12). The blade is broken off.

9, 10. Polygnathus tuberculatus Hinde (p. B32).

9. Oral view, USNM 135045 (Bryant, 1921, pl. 12, fig. 9).

10. Oral view, USNM 135044 (Bryant, 1921, pl. 12, fig. 8). Free blade broken off.

11. Polygnathus collieri n. sp. (p. B27).

Oral view of a specimen figured by Bryant (1921, pl. 13, fig. 9) as $P$. caelatus. USNM 135050.

14-18. Polygnathus ordinatus Bryant. (Compare with Ziegler, 1965b, pl. 4, figs. 5, 6, 8-11, 14-16.) (p. B31).

14,15. Oral and aboral views, USNM 188772; USGS 4577-SD, Genundewa Limestone Member of Genesee Formation, Cayuga Creek (Dp-3).

16-18, Oblique, oral, and aboral views, USNM 188762; USGS 4553-SD, Genundewa Limestone Member of Genesee Formation, Cayuga Creek (Dp-3). 
GEOLOGICAL SURVEY

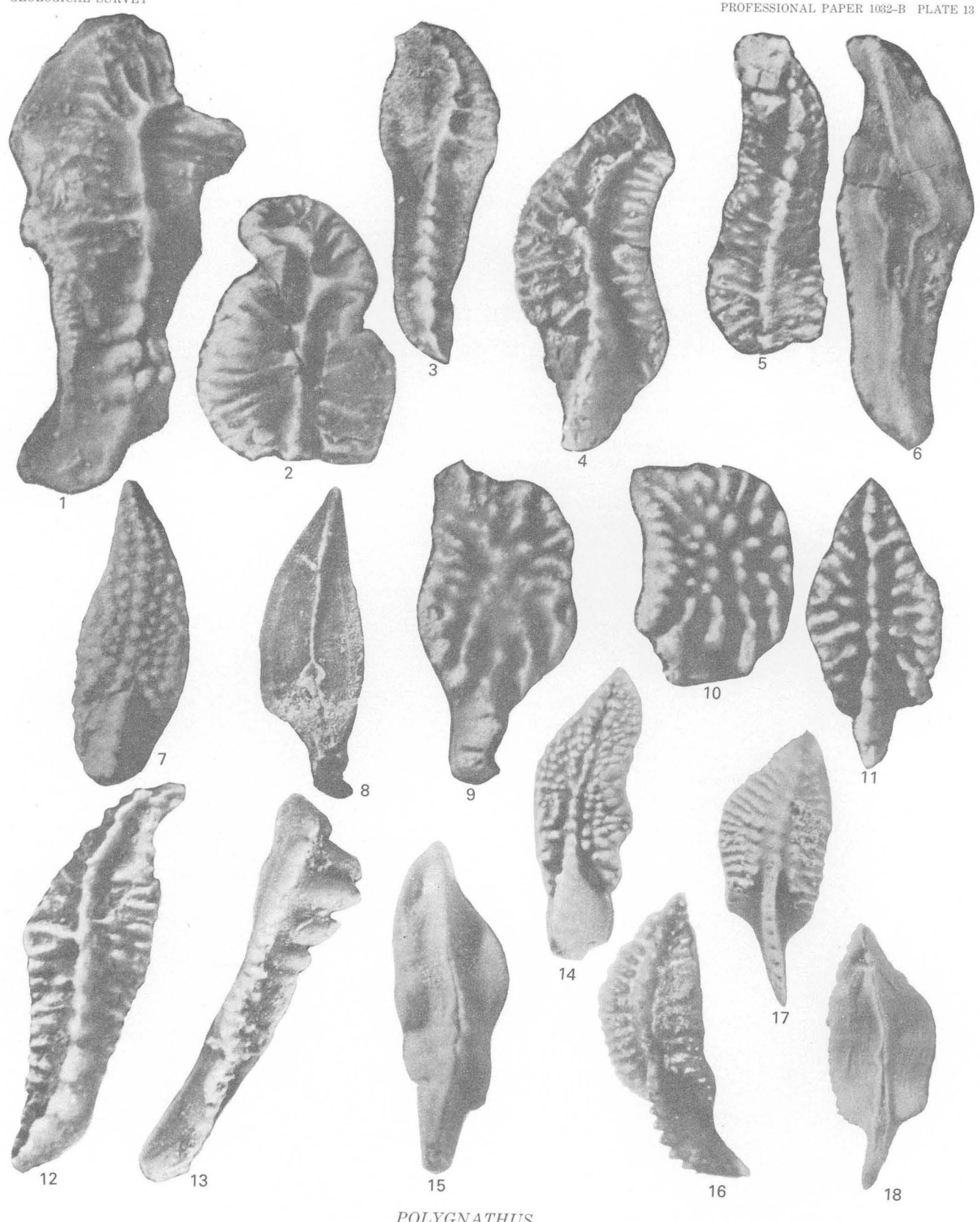




\section{PLATE 14}

[Al] figures $\times 30$, except fig. $16 \times 25$ and figs. 18 and $19 \times 35$. All specimens coated except fig. 18. Large, probably gerontic specimens from the R. R. Hibbard collection, University of Michigan, Museum of Paleontology, from the North Evans Limestone of Rickard (1964), Amsdell Creek, east of Amsdell Road, Wanakah, Eden $71 / 2$-minute quadrangle]

Figures 1-5. Polygnathus asymmetricus ovalis Ziegler and Klapper (p. B26).

1,2. Oral and aboral views, UMMP 60859 .

3, 4. Oral and aboral views, UMMP 60858.

5. Oral view, UMMP 60857. Basal plate present on this specimen.

6-19. Polygnathus ordinatus Bryant (p. B31).

6,7. Oblique-oral and aboral views, UMMP 60856. This specimen has an unusually large basal pit and anterior trough for this species.

8,9. Oblique-oral and aboral views, UMMP 60855 .

10,11. Oral and aboral views, UMMP 60854.

12,13. Oral and lateral views, UMMP 60853.

14-16. Oral, aboral, and lateral views, UMMP 60852.

17-19. Oral, lateral, and aboral views, UMMP 60851. 


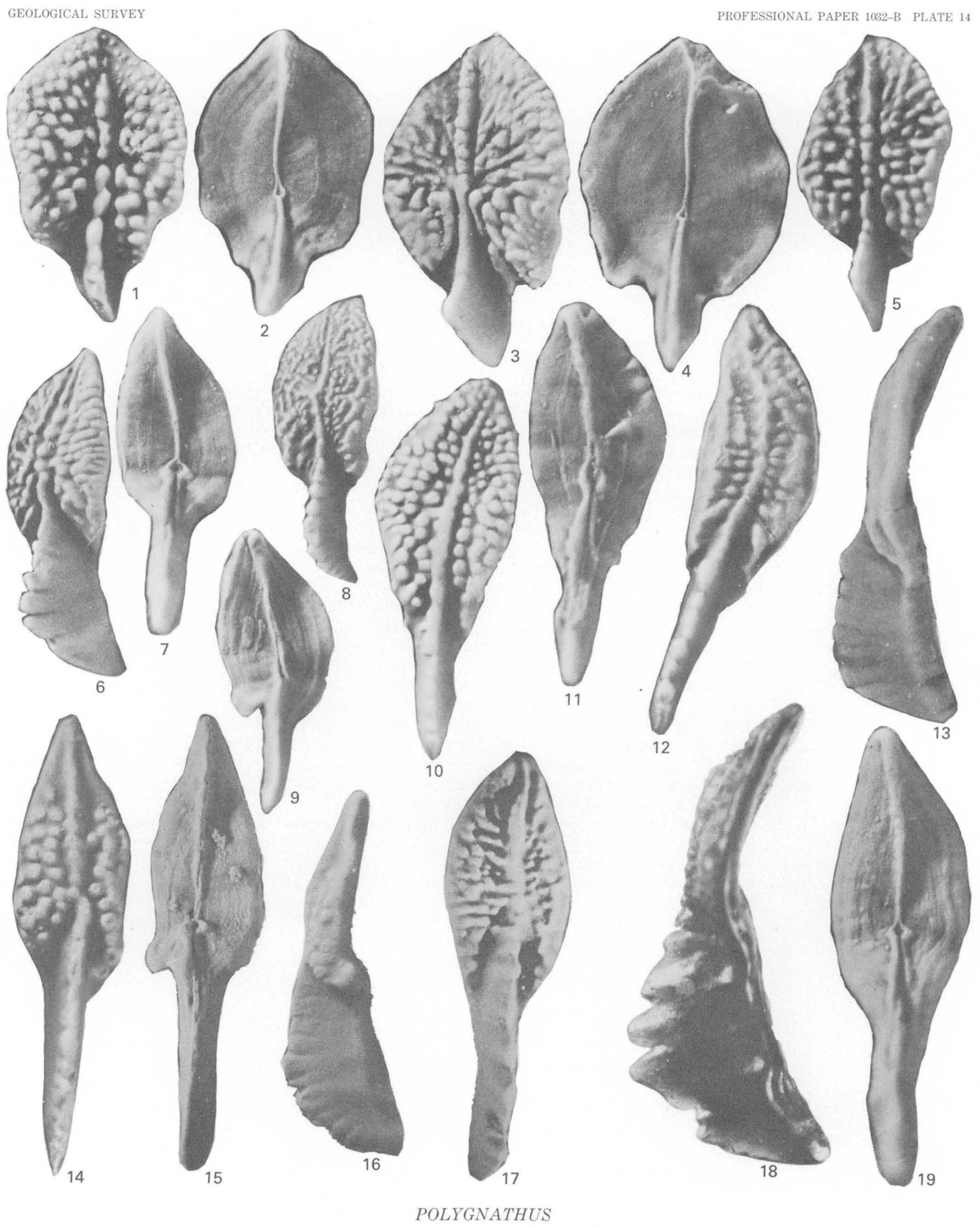




\section{PLATE 15}

[All figures $\times 30$. Figs. 1-3, 8, 15, 20, 21, 27 coated; others uncoated]

1-8. Polygnathus linguiformis linguiformis Hinde form delta, n. form (p. B30).

1. Oblique-oral view, USNM 188776; USGS 4577-SD, Genundewa Limestone Member of Genesee Formation, Cayuga Creek (Dp-3). Shows edge of attached basal plate.

2,3. Aboral and oral views, USNM 188798; USGS 6733-SD, Tully Limestone, Gage Gully (Cd-12). Note large basal pit and anterior trough.

4,5. Oral and aboral views, USNM 188782; USGS 6778-SD, Tully Limestone, Taughannock State Park (Gen-5). Aboral view shows conodont basal plate.

6, 7. Oral and aboral views, USNM 188780; USGS 6732-SD, Tully Limestone, Gage Gully (Cd-12).

8. Oral view, USNM 188781; USGS 4538-SD; Leicester Marcasite Member of Moscow Formation, of Sutton (1951), Eighteenmile Creek (Ed-1).

9-21. Polygnathus linguiformis linguiformis Hinde, form gamma of Bultynck (p. B30).

9,10. Oblique-oral and aboral views, USNM 188785; USGS 4553-SD, Genundewa Limestone Member of Genesee Formation, Cazenovia Creek (Dp-1). Note lack of white matter in denticles.

11,12. Oblique-oral and aboral views, USNM 188799; USGS 6733-SD, Tully Limestone, Gage Gully (Cd-12).

13,14. Oblique-oral and aboral views with preserved basal plate, USNM 188768; USGS 4557-SD, Genundewa Limestone Member of Genesee Formation, Cazenovia Creek (Dp-1).

15. Oral view, USNM 188783; USGS 4579-SD, Windom Member of Moscow Shale, Linden (Ba-2).

16,17. Oral and aboral views, USNM 188787; USGS 4553-SD, Genundewa Limestone Member of Genesee Formation, Cazenovia Creek (Dp-1).

18, 19. Oblique-oral and aboral views, USNM 188784; USGS 4553-SD, Genundewa Limestone Member of Genesee Formation, Cazenovia Creek (Dp-1).

20,21. Oblique-oral and aboral views, USNM 188777; USGS 6733-SD, Tully Limestone, Gage Gully (Cd-12).

22-27. Polygnathus dubius frons n. subsp. (p. B29).

22-24. Oral, aboral, and lateral views of holotype USNM 188767; USGS 7620-SD, Leicester Marcasite Member of Moscow Formation of Sutton (1951), Cazenovia Creek (Dp-1).

25, 26. Oral and aboral views, USNM 188768; USGS 4557-SD, Genundewa Limestone Member of Genesee Formation, Cazenovia Creek (Dp-1).

27. Oral view of specimen with broken blade and attached base, USNM 188766; USGS 3984-SD, Leicester Marcasite Member of Moscow Formation of Sutton (1951), Pike Creek (SC-1). 
GEOLOGICAL SURVEY
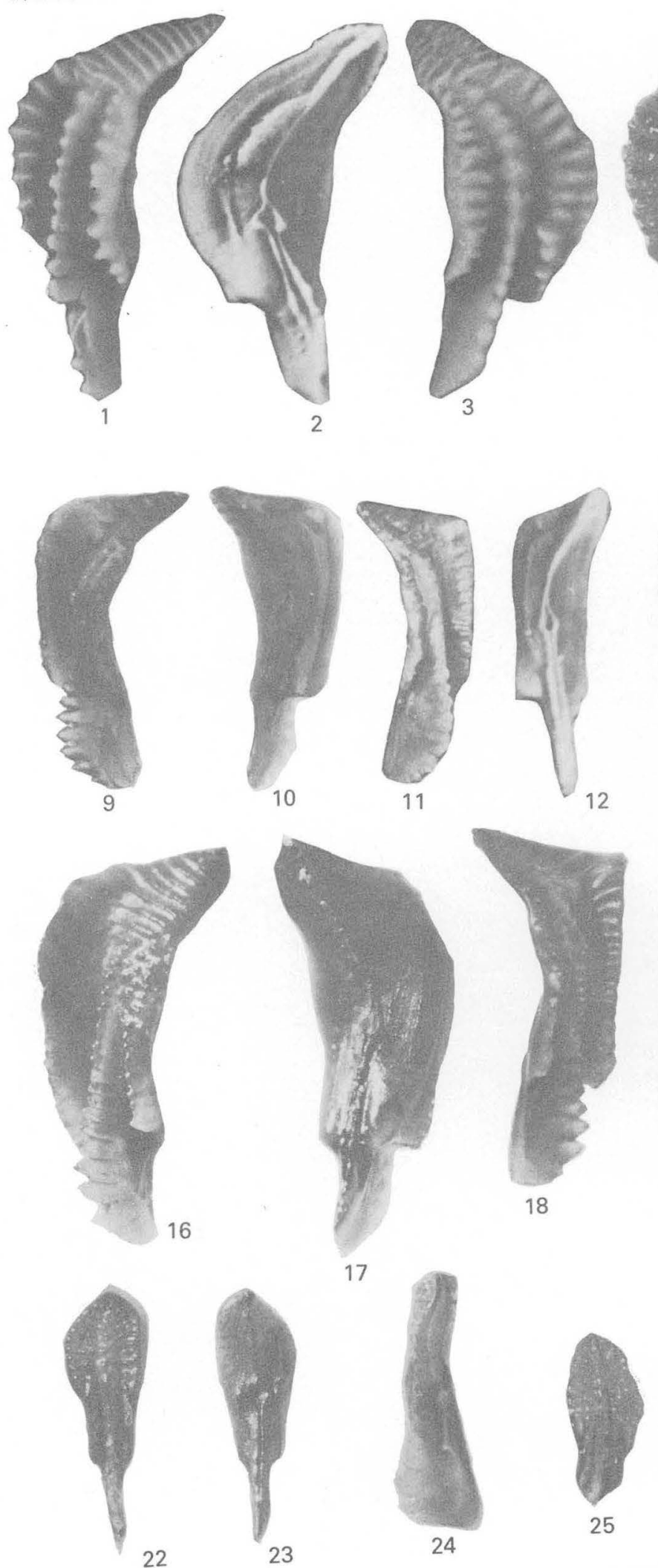

PROFESSIONAL PAPER 1032-B PLATE 15
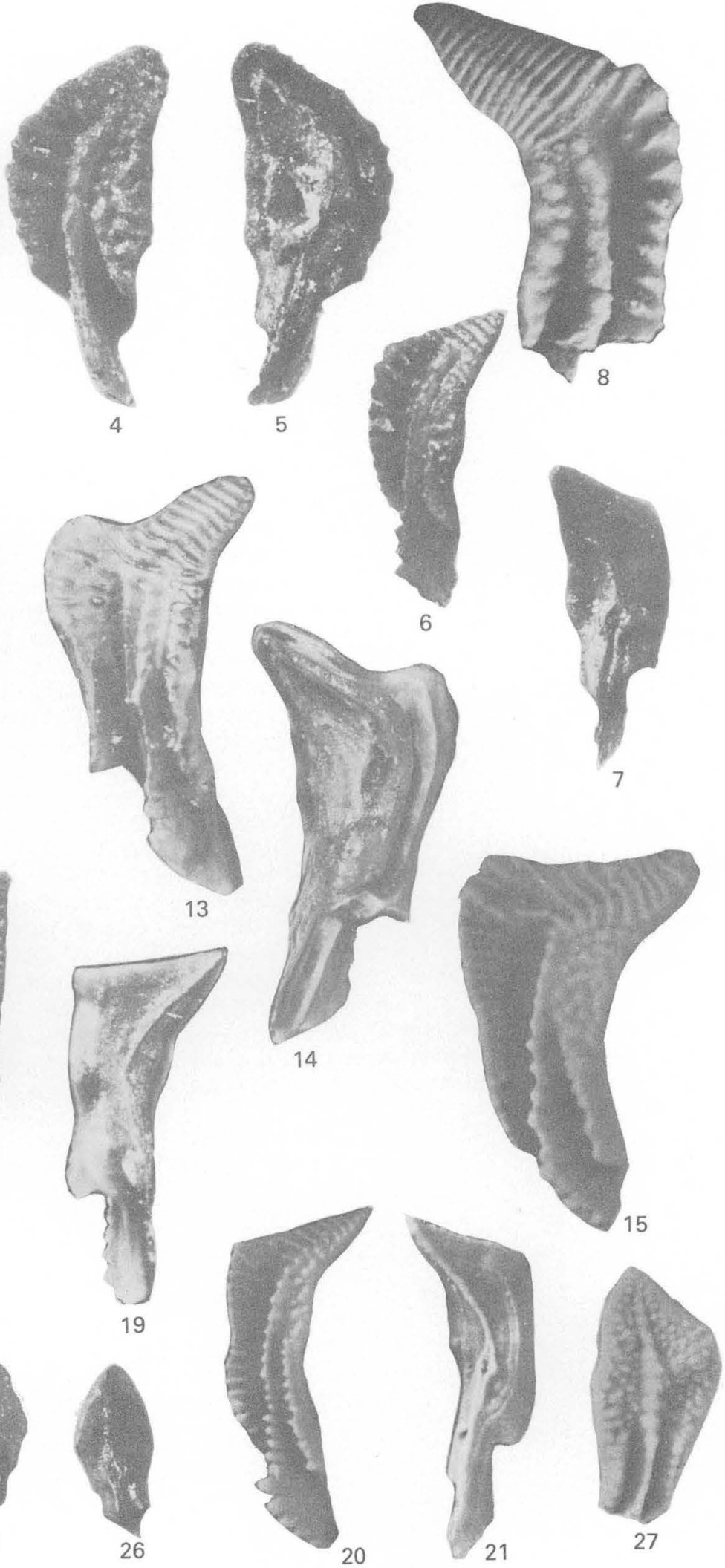

POLYGNATHUS 


\section{PLATE 16}

[All figures $\times 30$, except fig. $3 \times 25$; figs. 11-13 $\times$ 35. Figs. 9, 16-18, 20 uncoated; others coated. Figs. 1-7, 21-25 from the R. R. Hibbard col(1964), Amsdell Creek, east of Amsdell Road, Wanakah, Eden $71 / 2$-minute quadrangle

Figures 1,2. Polygnathus peracutus Bryant (p. B31).

Oral and aboral views, UMMP 60684.

3-20. Polygnathus ordinatus Bryant (p. B31).

3-5. Oral, aboral, and lateral views, UMMP 60683.

6, 7. Oral and lateral views, UMMP 60862.

8-10. Oral, oblique, and aboral views, USNM 188770; USGS 8970-SD, Genundewa Limestone Member of Genesee Formation, Bethany Center $(\mathrm{Ba}-3)$. A broad specimen. Note lack of white matter.

11-13. Oral, aboral, and lateral views, USNM 188759; USGS 7619-SD, Genundewa Limestone Member of Genesee Formation, Clover Bank quarry (Ed-2). Note: No white matter in denticles. Denticles are clear.

14-16. Oral, aboral, and lateral views, USNM 164321; USGS 4538-SD, Leicester Marcasite Member of Moscow Formation of Sutton (1951), Eighteenmile Creek (Ed-1). White matter not present.

17, 18. Oral and aboral views, USNM 188771; USGS 4569-SD, Leicester Marcasite Member of Moscow Formation of Sutton (1951), Cayuga Creek (Dp-3). Aboral surface has a large aberrent callous, apparently formed from the basal plate.

19,20. Oral and aboral views, USNM 188760; USGS 4553-SD, Genundewa Limestone Member of Genesee Formation.

21, 22. Polygnathus sp. [not discussed in text; refer to tables].

Oral and aboral views, UMMP 60861, Genundewa Limestone Member of Genesee Formation, Cazenovia Creek (Dp-1). Aberrant specimen of $P$. ordinatus.

23-25. Polygnathus asymmetricus ovalis Ziegler and Klapper (p. B26).

Oral, aboral, and lateral views of a large specimen, UMMP 60860. 


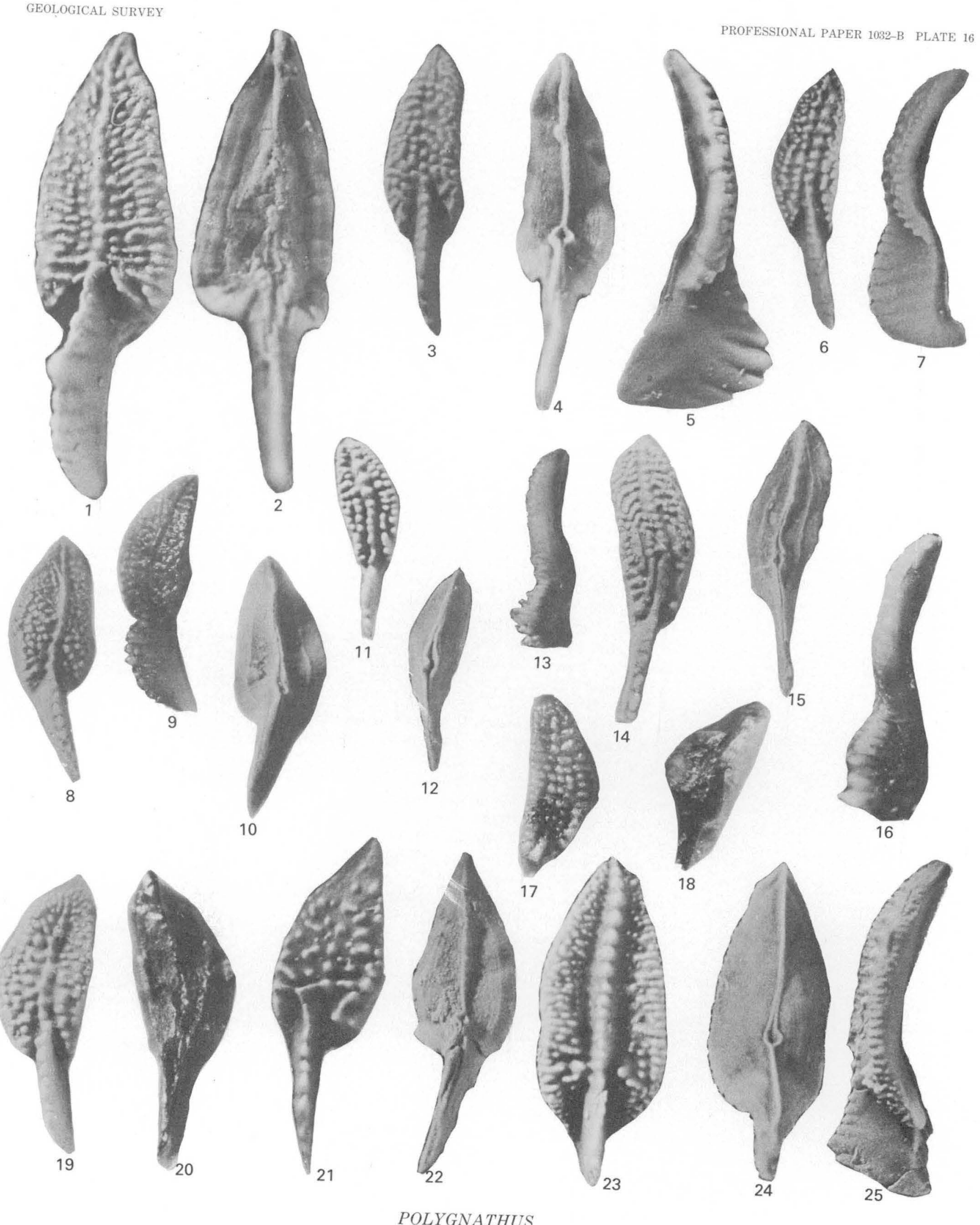




\section{PLATE 17}

[Figs. 2, 6-9, 21-43 $\times$ 30. Figs. 1, 3-5, 10-15, 18-20 $\times$ 45. Figs. 16 and 17 about $\times$ 50. Figs. 8, 12, 15, 21, 22, 26, 28-30, 38-46 uncoated: others

1-3. Oral, aboral, and lateral views, USNM 188793; USGS 6754-SD, West River Shale Member of Genesee Formation, Chidsey Point (Py-7). Figs. 1 and $3, \times 45$.

4-6. Oral, aboral, and lateral views, USNM 188794; USGS 6754-SD, West River Shale Member of Genesee Formation, Chidsey Point (Py-7). Figs. 4, $5 \times 45$.

7-9. Oral, aboral, and lateral views, USNM 188809; USGS 6754-SD, West River Shale Member of Genesee Formation, Chidsey Point ( $\mathrm{Py}-7)$.

10-12, 16-27. Polygnathus rhenanus marijae n. subsp. (p. B31).

10-12. Oral, aboral, and lateral views of holotype, UMMP 60867, R. R. Hibbard Colln., North Evans Limestone of Rickard (1964), Amsdell Creek.

16-18. Oral, aboral, and lateral views, USNM 208020; USGS 6733-SD, Tully Limestone, Gage Gully (Cd-12). Fig. 16, × 52, fig. 17, $\times$ 50, fig. 18, $\times 45$.

19,20. Oral and aboral views, USNM 188774; USGS 4553-SD, Genundewa Limestone Member of Genesee Formation, Cazenovia Creek (Dp-1). Blade broken.

21-23. Oral, aboral, and lateral views, USNM 188756; USGS 6733-SD, Tully Limestone, Gage Gully (Cd-12). Blade broken.

24-26. Oral, aboral, and lateral views of an immature specimen, USNM 188775; USGS 4553-SD, Genundewa Limestone Member of Genesee Formation, Cazenovia Creek (Dp-1). Blade broken.

27. Oral view, USNM 188792; USGS 7622-SD, North Evans Limestone of Rickard (1964), Eighteenmile Creek (Ed-1). Blade broken.

13-15. Polygnathus decorosus Stauffer (p. B29).

Oral, aboral, and lateral views, USNM 188907; USGS 6733-SD, Tully Limestone, Gage Gully (Cd-12). Note lack of asymmetry in this specimen.

28-31. Polygnathus " $V$ " (p. B32).

28,29 . Oral and aboral views of specimen with broken blade, USNM 188789; USGS 6733-SD, Tully Limestone, Gage Gully (Cd-12).

30,31. Oral and aboral views, USNM 188790; USGS 6733-SD, Tully Limestone, Gage Gully (Cd-12).

32-34. Polygnathus aff. $P$. collieri n. sp. [not discussed in text].

Oral, aboral, and lateral views, R. R. Hibbard Colln., UMMP 60865, North Evans Limestone of Rickard (1964), Amsdell Creek, N.Y.

35-37. Polygnathus aff. P. brevilaminus Branson and Mehl (p. B27).

Oblique-oral, lateral, and aboral views, R. R. Hibbard Colln., UMMP 60866, North Evans Limestone of Rickard (1964), Amsdell Creek, N.Y.

38-40. Polygnathus aff. P. trigonicus Bischoff and Ziegler (p. B32).

Oral, aboral, and lateral views, USNM 188764; USGS 7623-SD, Marathon Sandstone Member of Ithaca facies of Caster (1933), in Ithaca Member of Genesee Formation (I-2).

41-46. Polygnathus cf. $P$. robusticostatus Bischoff and Ziegler [not discussed in text].

41-43. Oral, aboral, and lateral views, USNM 188765; USGS 6733-SD, Tully Limestone, Gage Gully (Cd-12).

44-46. Oral, aboral, and lateral views, USNM 188811; USGS 6740-SD, Tully Limestone, Bellona (Py-7). 

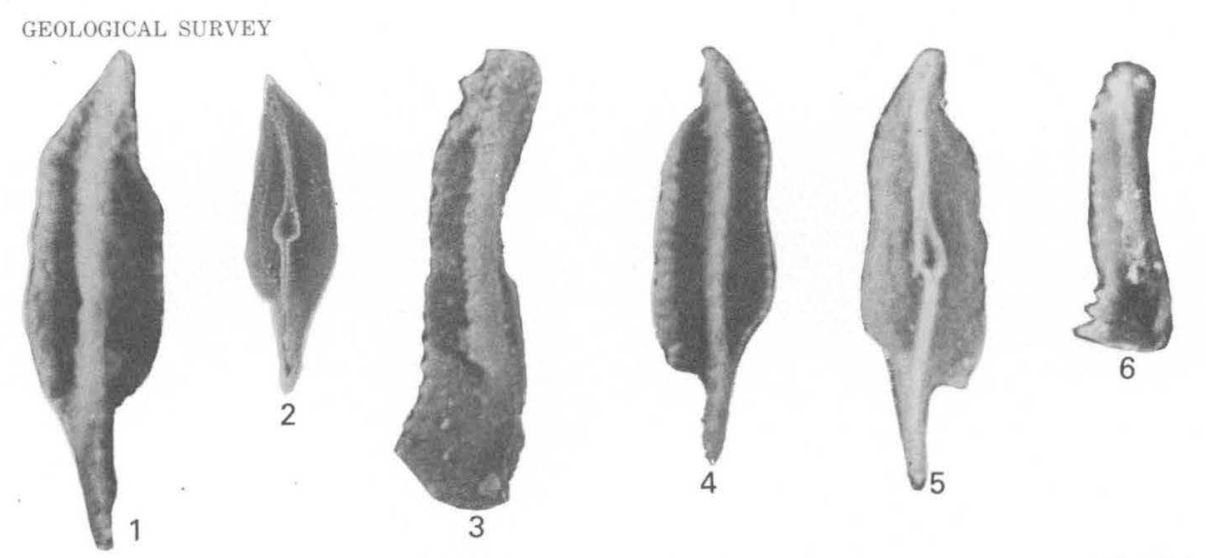

PROFESSIONAL PAPER 1032-B PLATE 17
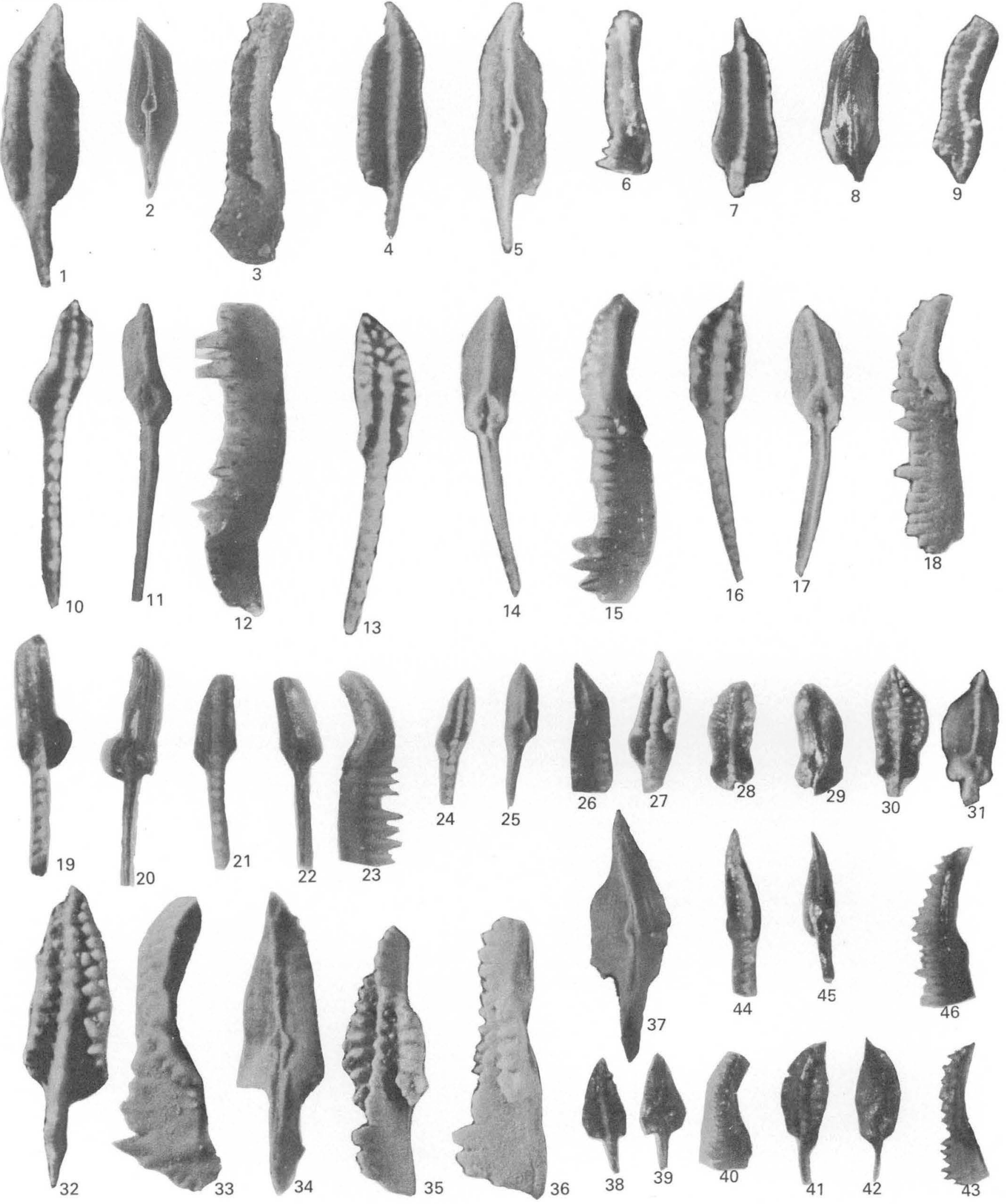

POLYGNATHUS 


\section{PLATE 18}

[All figures $\times 30$ except figs. 3, 24, $25 \times 35$, and fig. $4 \times 2$. Figs. 1-7, 21-23, 25-28 coated; others not coated]

Figures 1-12. Polygnathus rhenanus marijae n. subsp. (p. B31).

1,2. Oral and lateral views of holotype UMMP 60867, R. R. Hibbard Colln., North Evans Limestone of Rickard (1964), Amsdell Creek. (Compare with pl. 17, figs. 10-12, same specimen not coated.)

3, 4. Oral and lateral views of specimen with broken blade, UMMP 60878, R. R. Hibbard Colln., North Evans Limestone of Rickard (1964), Amsdell Creek.

5. Oral view, USNM 188788; USGS 3984-SD, Leicester Marcasite Member of Moscow Formation of Sutton (1951), Pike Creek (SC-1).

6. Aboral view, USNM 188791; USGS 4870-SD, Windom Member of Moscow Shale, Linden (Ba2).

7. Lateral view of broken specimen USNM 188810; USGS 4870-SD, Windom Member of Moscow Shale, Linden $(\mathrm{Ba}-2)$.

8. Lateral view of a free blade, USNM 188758; USGS 6733-SD, Tully Limestone, Gage Gully (Cd-12) showing full length of blade and alternating denticles.

9-11. Oral, aboral, and lateral views of a juvenile specimen, USNM 188757; USGS 6733-SD, Tully Limestone, Gage Gully (Cd-12). Note white matter.

12. Lateral view, USNM 188774; USGS 4553-SD, Genundewa Limestone Member of Genesee Formation, Cazenovia Creek (Dp-1). Note white matter. Denticles apparently inserted.

13-18. Polygnathus dubius dubius Hinde (p. B29).

13-15. Oral, aboral, and lateral views, USNM 188797; USGS 3958-SD, Genundewa Limestone Member of Genesee Formation, Genundewa Point (Nap-4).

16-18. Oral, aboral, and lateral views, USNM 188796; USGS 4577-SD, Genundewa Limestone Member of Genesee Formation, Cayuga Creek (Dp-3).

19-31. Nothognathella ziegleri (Clark and Ethington) (p. B38).

West River Shale Member of Genesee Formation, Chidsey Point (Py-7).

19. Oral view, USNM 188667; USGS 6754-SD.

20-22. Oral, aboral, and lateral views, USNM 188668; USGS 6754-SD.

23, 24. Oral and aboral views, USNM 188666; USGS 6754-SD.

25. Oral view, USNM 188664; USGS 6754-SD.

26. Oral view, USNM 188665; USGS 6754-SD.

27, 28. Lateral and oblique views, USNM 188663; USGS 6754-SD.

29-31. Oral, aboral, and lateral views, USNM 188669; USGS 6754-SD. 
GEOLOGICAL SURVEY

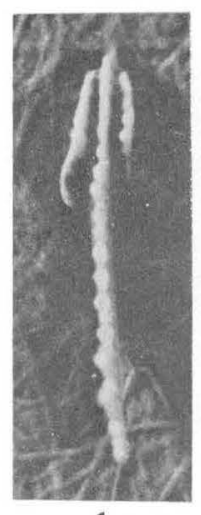

1

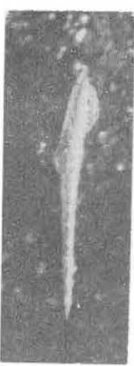

9

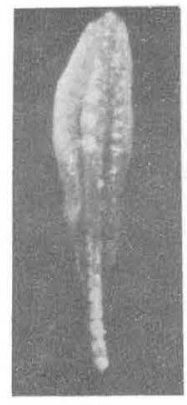

16

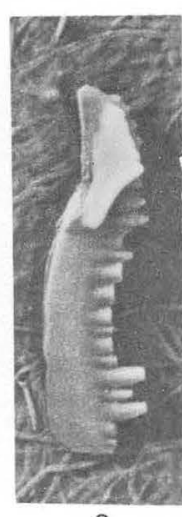

2

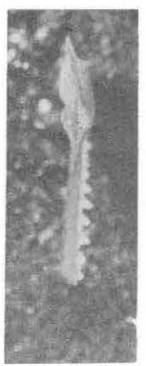

10

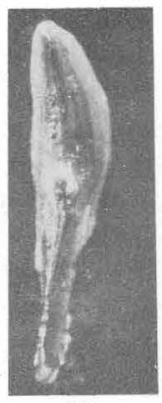

17
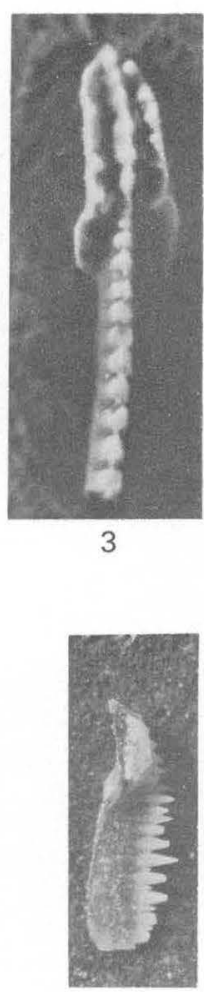

11

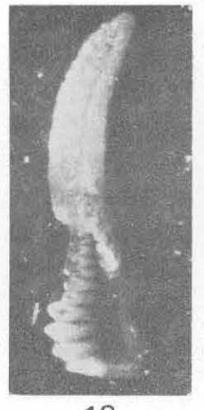

18

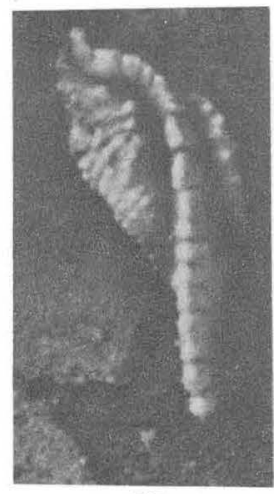

25

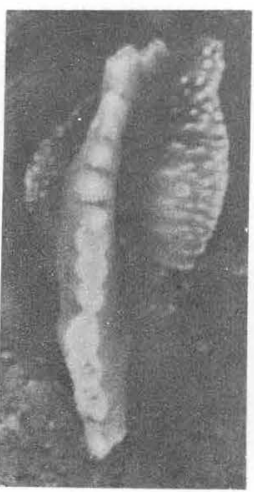

26
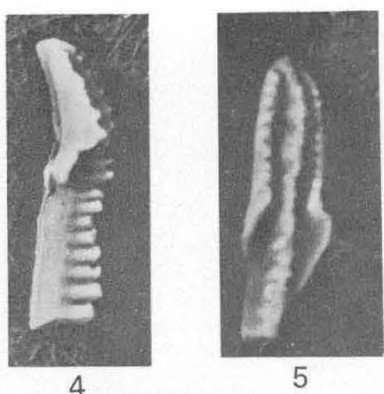

5
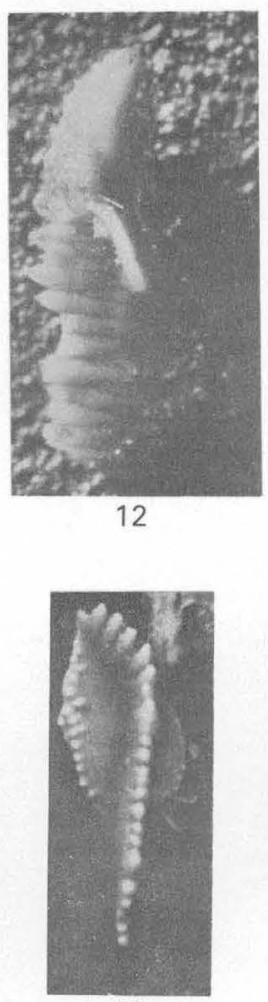

19
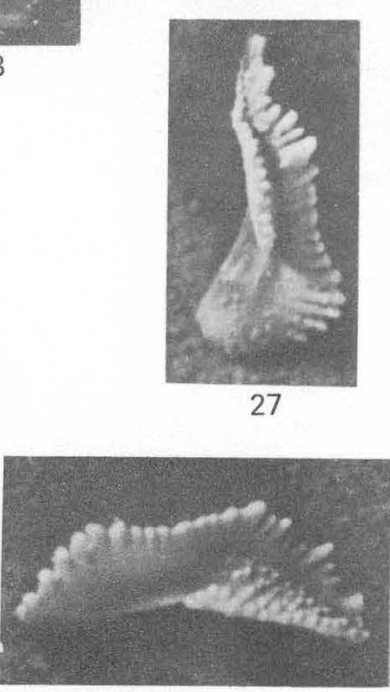

28
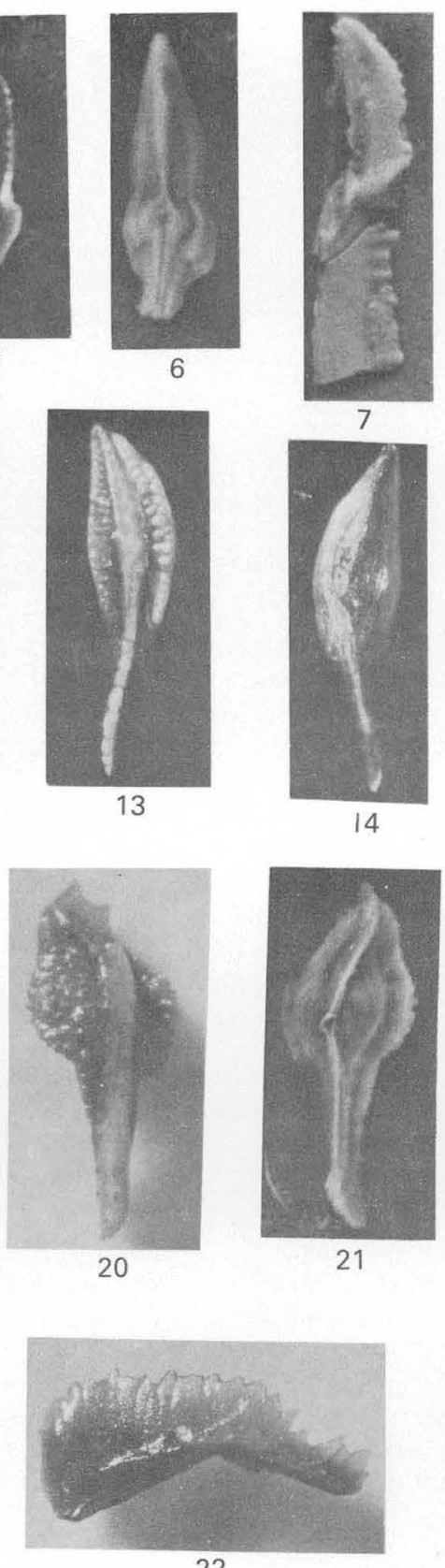

22

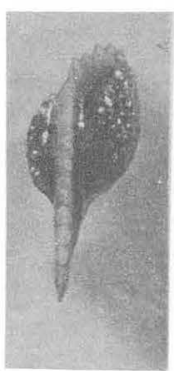

29
21
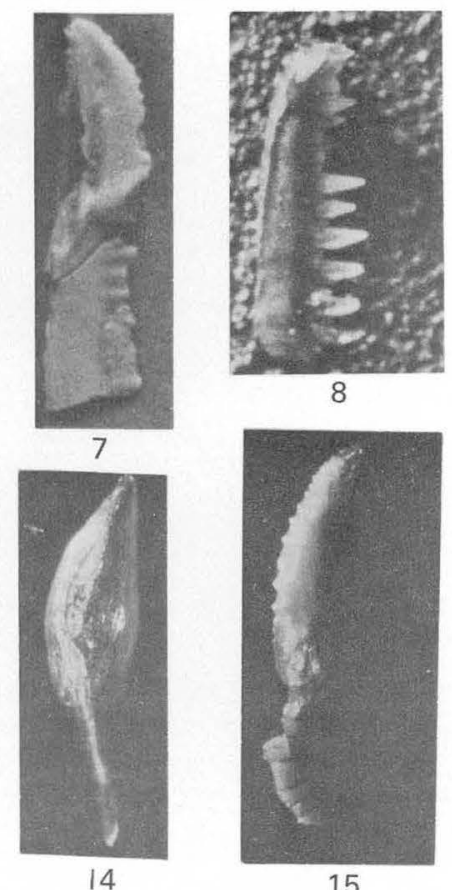

15

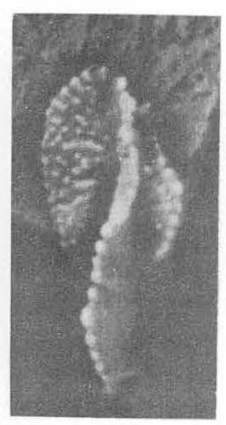

23
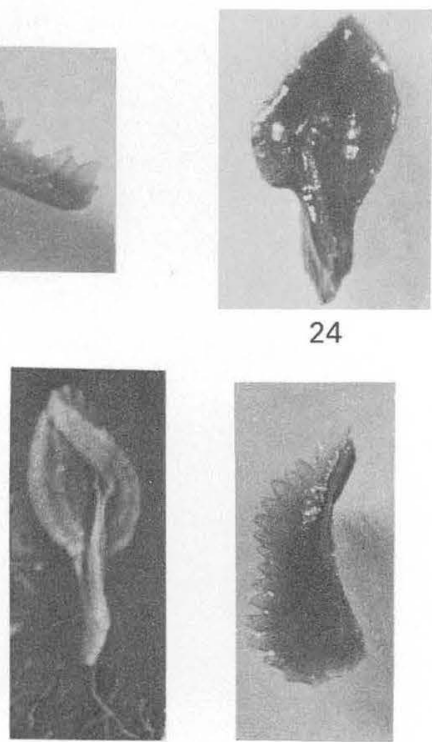

30

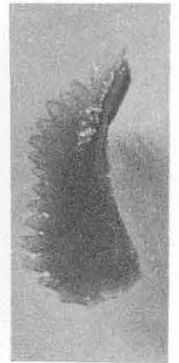

31

POLYGNATHUS AND NOTHOGNATHELLA 


\section{PLATE 19}

[All figures $\times$ 30. Figs. 1-9 coated; others not coated. Figs. 1-9 from the R. R. Hibbard collection, University of Michigan, Museum of Paleontology, North Evans Limestone of Rickard (1964), Amsdell Creek]

Figures 1,2. Prioniodina macrodenta (Bryant) (p. B46). Oral and aboral views, UMMP 60868.

3. Polygnathus species [not discussed in text]. Oral view of a twisted specimen, probably pathologic, UMMP 60869.

4, 5. "Polygnathus norrisi" Uyeno (p. B31).

Oral and aboral views, UMMP 60870. Probably these are pathologic individuals.

6-9. Spathognathodus sannemanni Bischoff and Ziegler (p. B33).

6, 7. Oral and aboral views, UMMP 60871 .

8, 9. Oral and aboral views, UMMP 60872.

10-15. Pandorinellina insita (Stauffer) (p. B33).

10-12. Lateral, oral, and aboral views, USNM 188998; USGS 7623-SD, Marathon Sandstone Member of Ithaca facies of Caster (1933), in Ithaca Member of Genesee Formation, Williams Brook (I-2).

13-15. Outer lateral, aboral, and inner lateral views, USNM 188773; USGS 7623-SD. Marathon Sandstone Member of Ithaca facies of Caster (1933).

16-21. Spathognathodus semialternans Wirth (p. B33).

16-18. Lateral inner and outer views and aboral view, USNM 188999; USGS 6756-SD, Crosby Sandstone Member of Standish Formation as used by Torrey and others (1932), Sunset Point (Py15).

19-21. Lateral outer and inner views and aboral views, USNM 189001; USGS 9070-SD, Tully Limestone, Tinker Falls ( Tu-2).

22-25. Spathognathodus aff. S. strigosus (Branson and Mehl). (p. B33).

Inner, outer lateral views and oral and aboral views, USNM 189000; USGS 8964-SD, Genundewa Limestone Member of Genesee Formation, Beards Creek (Cl-3).

26-30. Synprioniodina alternata Bassler (p. B40).

26, 27. Lateral inner and outer views, USNM 189011; USGS 4574-SD, Genundewa Limestone Member of Genesee Formation, Elevenmile Creek (At-1).

28-30. Lateral outer and inner (inner uncoated and coated) views, USNM 189010; USGS 8122-SD, West River Shale Member of Genesee Formation, Fall Brook (Cl-4).

31-36. Synprioniodina prona Huddle (p. B40).

31,32. Inner and outer views, USNM 189013; USGS 8122-SD, West River Shale Member of Genesee Formation, Fall Brook (Cl-4).

33,34. Outer and inner views, USNM 188825; USGS 4586-SD, Genundewa Limestone Member of Genesee Formation, Taunton Gully (Cl-2).

35, 36. Outer and inner views, USNM 189014; USGS 8122-SD, West River Shale Member of Genesee Formation, Fall Brook (Cl-4). 

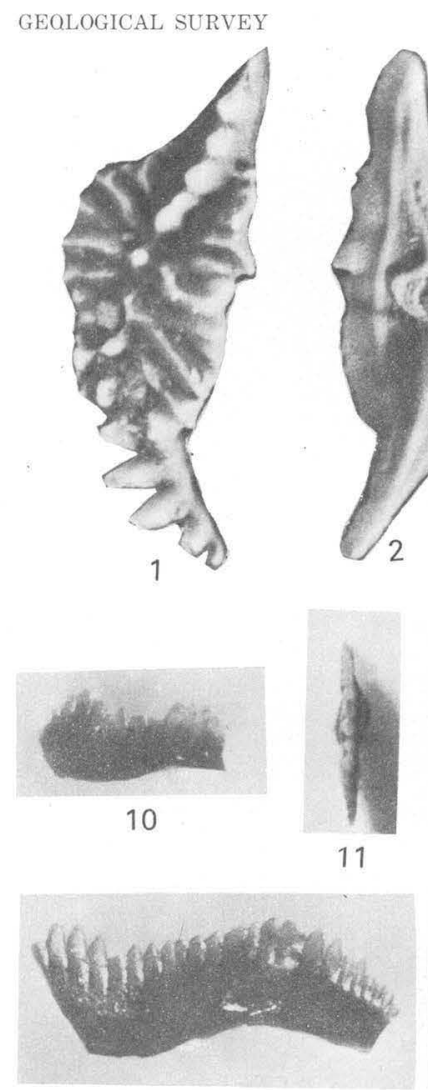

16

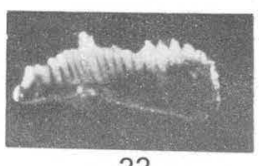

22

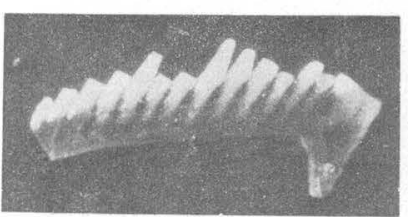

26

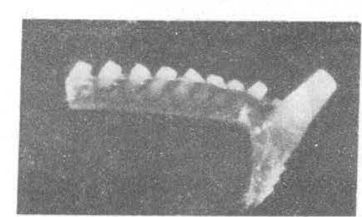

29

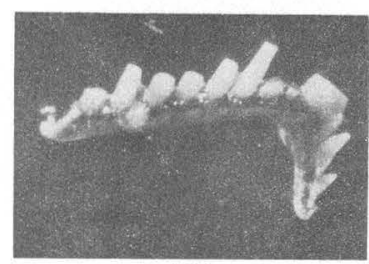

33
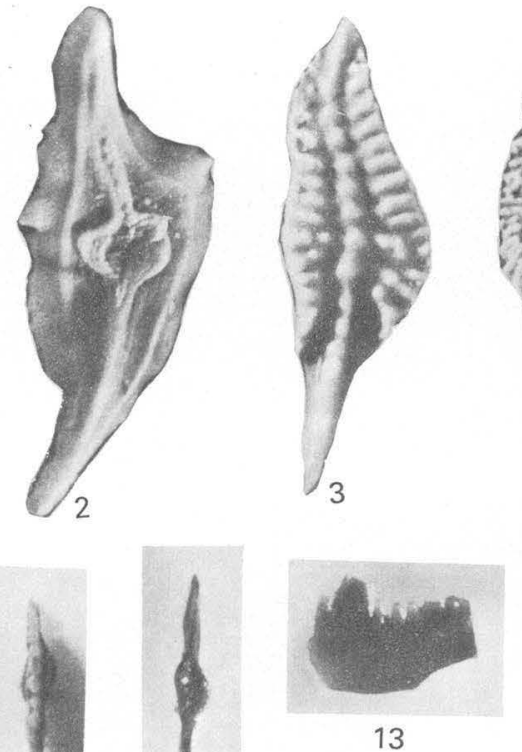

12

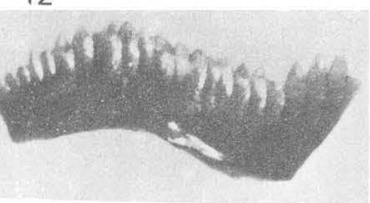

17

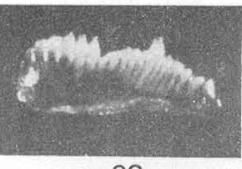

23

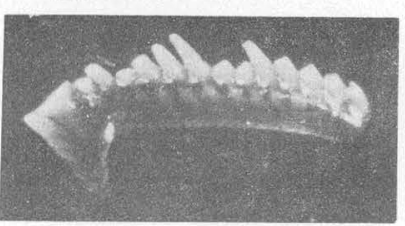

27

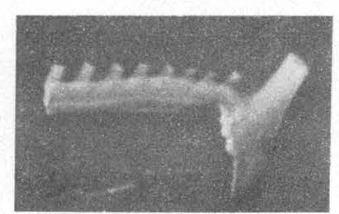

30

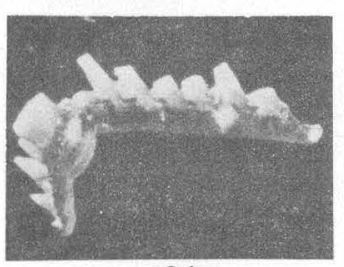

34
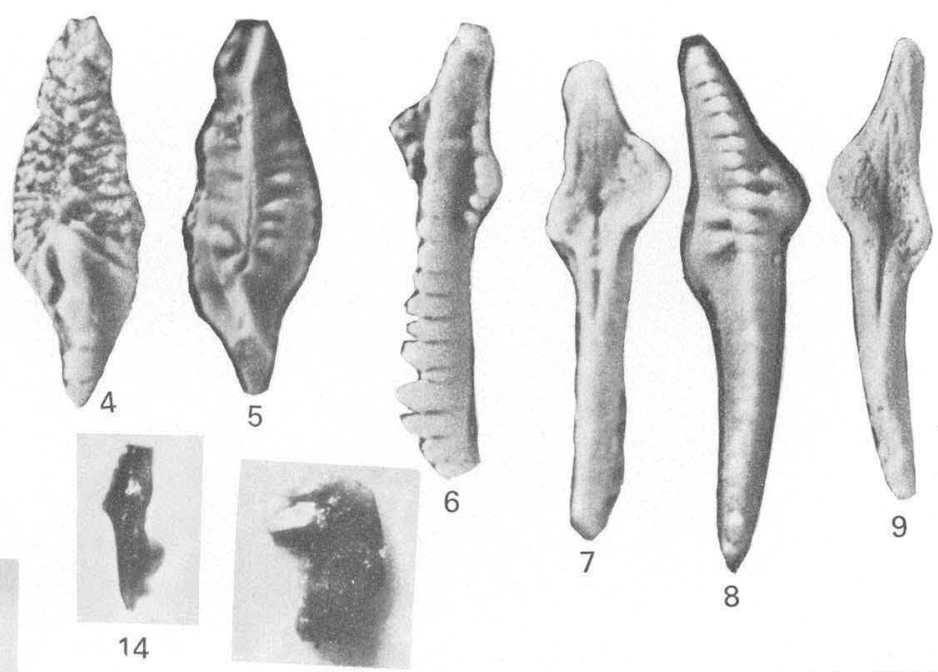

15
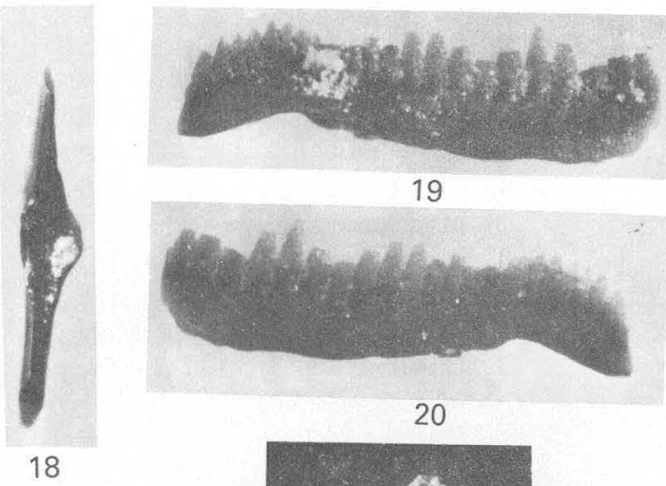

20
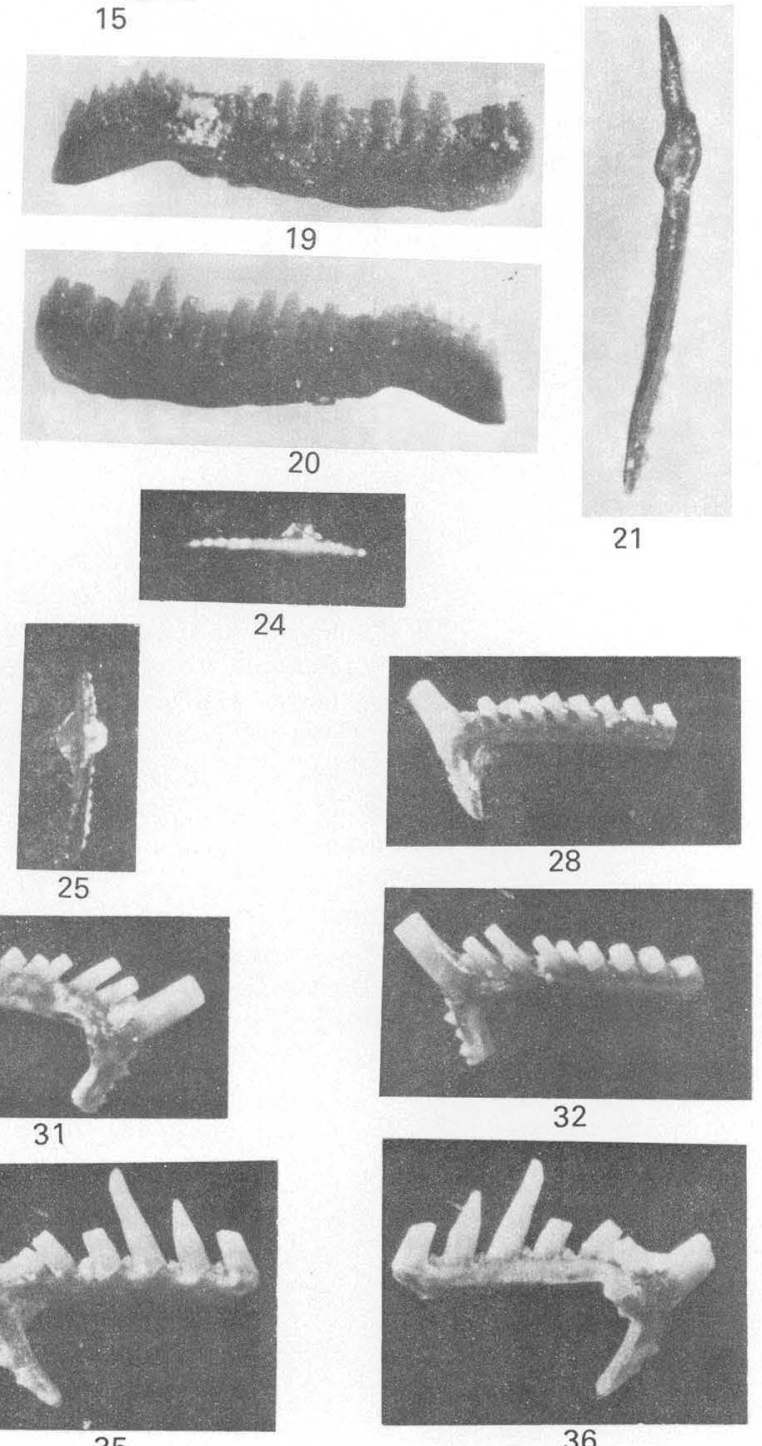

36

PRIONIODINA, POLYGNATHUS, SPATHOGNATHODUS, PANDORINELLINA, AND SYNPRIONIODINA 


\section{PLATE 20}

[All figures $\times 30$. Figs. 1-6, 8-11, 13, 20, 21, 24-28 coated. Figs. 7, 12, 14-19, 22, 23 uncoated

FIGURES

1-4. Bryantodus sp. (p. B38).

Lodi Limestone of Clarke (in Lincoln 1895), Penn Yan Shale Member of Genesee Formation, Mill Creek (Ov-10).

1,2. Outer and inner views, USNM 188837; USGS 6768-SD. Note inner ledge with nodes.

3 , 4. Inner and outer views, USNM 188838; USGS 6768-SD.

5, 6, 8-11. Bryantodus nitidus Ulrich and Bassler (p. B36).

West River Shale Member of Genesee Formation, Chidsey Point (Py-7).

5,6. Outer and inner views, USNM 188844; USGS 6754-SD. Posterior bar broken off. Note lateral attachment areas.

8,9. Inner and outer views, USNM 188842; USGS 6754-SD. Note strong lateral node.

10,11. Outer and inner views, USNM 188841; USGS $6754-S D$. Note lack of an outer node.

7,12-20. Ozarkodina macra Branson and Mehl (p. B39).

7. Outer view, USNM 188878; USGS 4574-SD, Genundewa Limestone Member of Genesee Formation, Elevenmile Creek (At-1). Note distinct white matter deep in the bar.

12,13. Outer and inner views, USNM 188812; USGS 8122-SD, West River Shale Member of Genesee Formation, Fall Brook (Cl-4).

14, 15. Outer and inner views, USNM 188813; USGS 8122-SD, Genundewa Limestone Member of Genesee Formation, Elevenmile Creek (At-1).

16,17. Outer and inner views, USNM 188815; USGS 4574-SD, Genundewa Limestone Member of Genesee Formation, Elevenmile Creek (At-1).

18-20. Outer and inner views (inner uncoated and coated), USNM 188814; USGS 4526-SD, Genundewa Limestone Member of Genesee Formation, Pike Creek (SC-1). Surface details are best shown by coating but the distribution of white matter is concealed.

21, 22. Bryantodus retusus (Bryant) (p. B36).

Outer and aboral views, USNM 188858; USGS 4577-SD, Genundewa Limestone Member of Genesee Formation, Cayuga Creek (Dp-3). Note broad base and wide attachment area.

23, 24. Ozarkodina ef. O. macra Branson and Mehl [not discussed in text].

Outer and inner views, USNM 188816; USGS 6658-SD, Penn Yan Shale Member of Genesee Formation, Dewey Hill (Cl-5). This specimen has a longer bar and more denticles than typical specimens, perhaps gerontic.

25-28. Ozarkodina lata Bischoff and Ziegler (p. B39).

Tully Limestone, Gage Gully, (Cd-12).

25, 26. Outer and inner views, USNM 188845; USGS 6733-SD.

27, 28. Innner and outer views, USNM 188846; USGS 6733-SD. 
GEOLOGICAL SURVEY
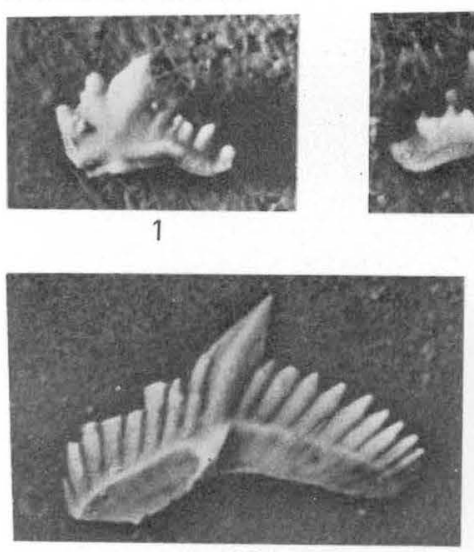

9

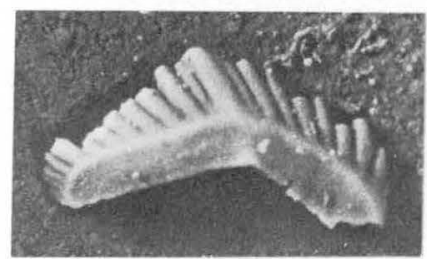

10

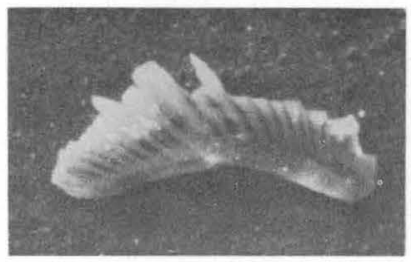

14

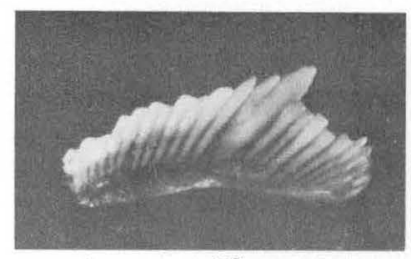

18

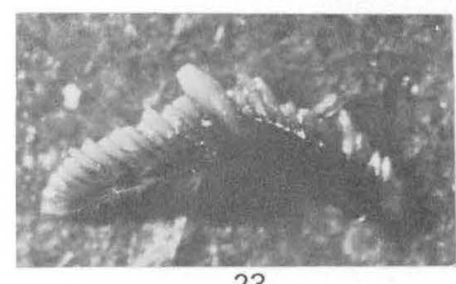

23

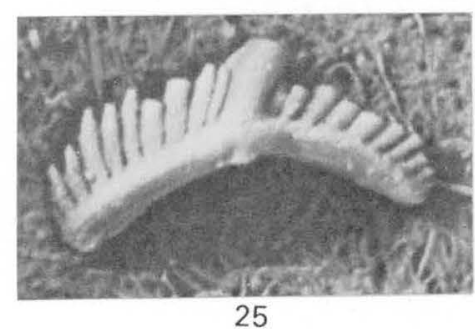

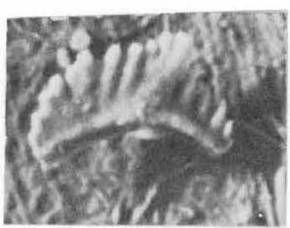

3
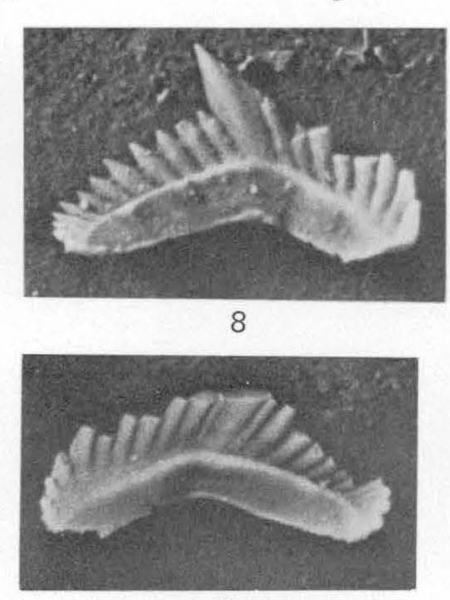

11

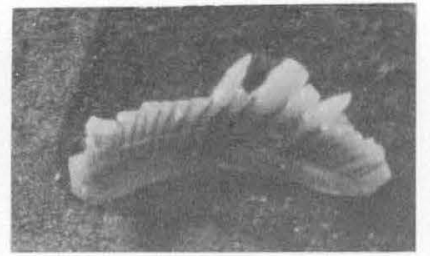

15

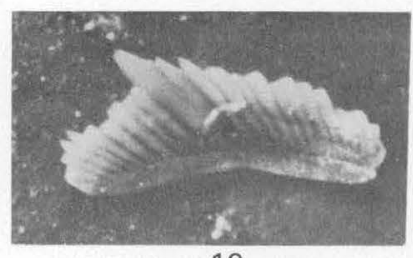

19

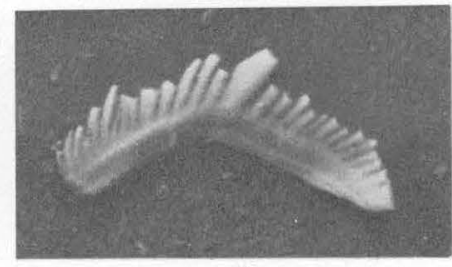

24

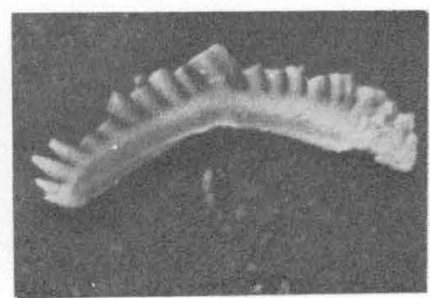

26

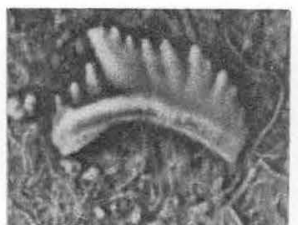

4

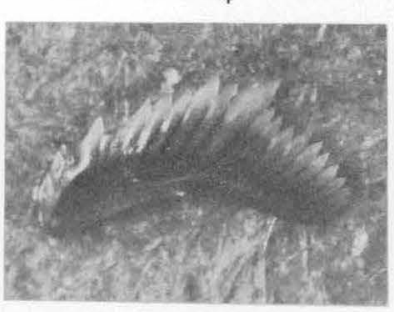

7

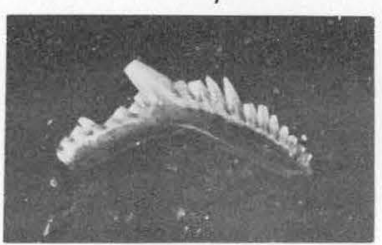

12

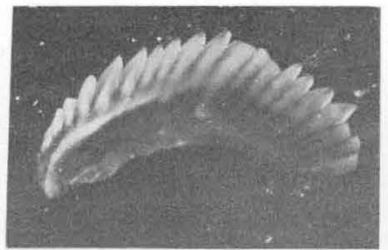

16

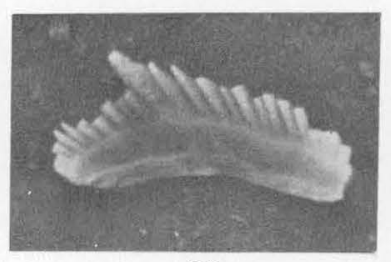

20
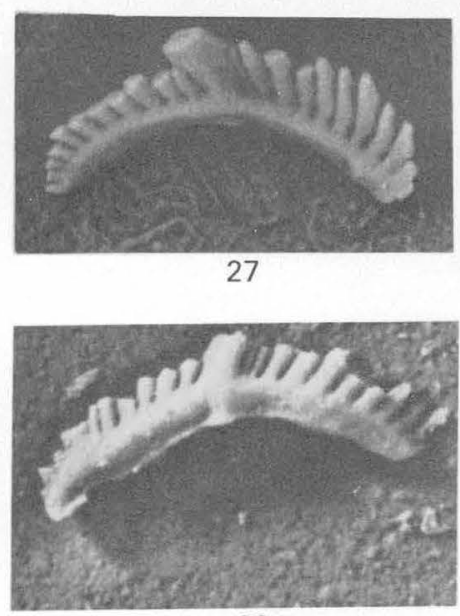

28
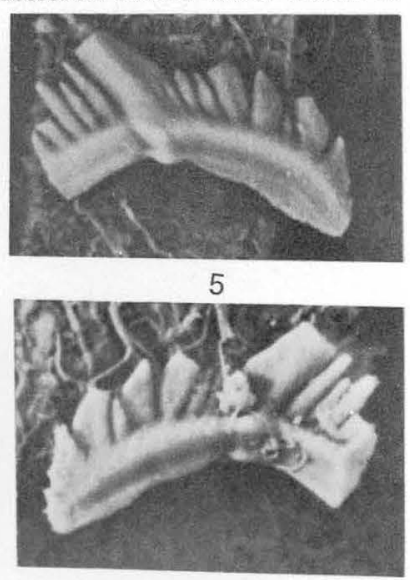

6

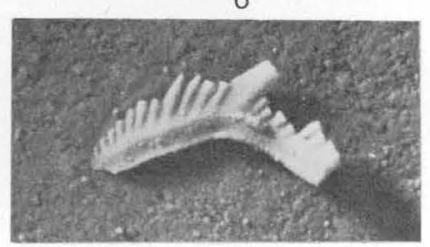

13

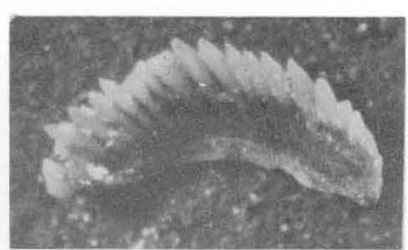

17

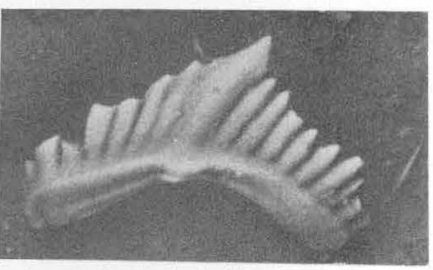

21

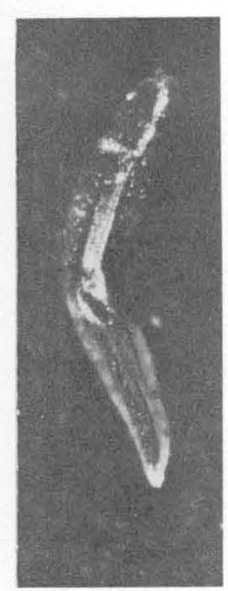

22

BRYANTODUS AND OZARKODINA 


\section{PLATE 21}

[All figures $\times 30$. Figs. $2,8,10,12,13,15,28$ uncoated; others coated]

FigURES 1,2. Bryantodus retusus? (Bryant) (p. B36).

Inner and outer views showing prominent ledge on posterior bar. Tip of bar broken off. USNM 188849; USGS 6799-SD, West River Shale Member of Genesee Formation, Fall Brook (Cl-4).

3-22. Bryantodus retusus (Bryant) (p. B36).

3,4. Outer and inner views, USNM 188840; USGS 6754-SD, West River Shale Member of Genesee Formation, Chidsey Point $(\mathrm{Py}-7)$. Note the nodose inner platform.

5,6. Outer and inner views of specimen with strong lateral expansions below cusp. USNM 188857; USGS 4577-SD, Genundewa Limestone Member of Genesee Formation, Cayuga Creek (Dp-3).

7,8. Outer and inner views, USNM 188855; USGS 4577-SD. Genundewa Limestone Member of Genesee Formation, Cayuga Creek (Dp-3). Note white matter confined to denticles. Posterior bar broken.

9, 10. Outer and inner views of small specimen, USNM 188850; USGS 8122-SD, West River Shale Member of Genesee Formation, Fall Brook (Cl-4). Posterior bar broken.

11-13. Outer, inner and aboral views, USNM 188856; USGS 4577-S.D, Genundewa Limestone Member of Genesee Formation, Cayuga Creek $(\mathrm{Dp}-3)$. Note white matter distribution, broad lateral attachment area, and thick bar.

14,15. Outer and inner views, USNM 188852; USGS 4538-SD, Leicester Marcasite Member of Moscow Formation of Sutton (1951), Eighteenmile Creek (Ed-1).

16. Outer view of specimen with double ridge on the basal expansion, USNM 188859; USGS 4577$\mathrm{SD}$, Genundewa Limestone Member of Genesee Formation, Cayuga Creek (Dp-3).

17,18. Outer and inner views of specimen with very large basal expansion, USNM 188860; USGS 4577-SD, Genundewa Limestone Member of Genesee Formation, Cayuga Creek (Dp-3).

19,20. Outer and inner views, USNM 188861; USGS 4577-SD, Genundewa Limestone Member of Genesee Formation, Cayuga Creek (Dp-3).

21,22. Outer and inner views of specimen intermediate toward $B$. colligatus, USNM 188864; USGS 4577-SD, Genundewa Limestone Member of Genesee Formation, Cayuga Creek (Dp-3). 
GEOLOGICAL SURVEY
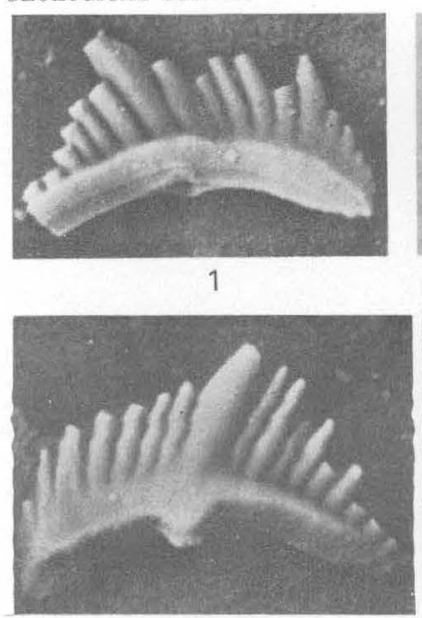

5

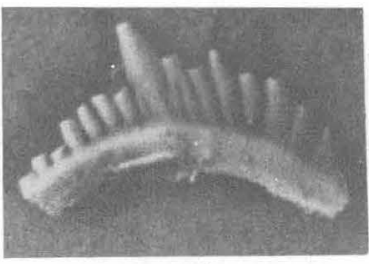

9

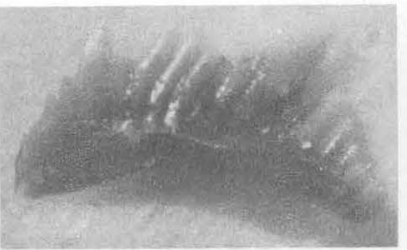

2

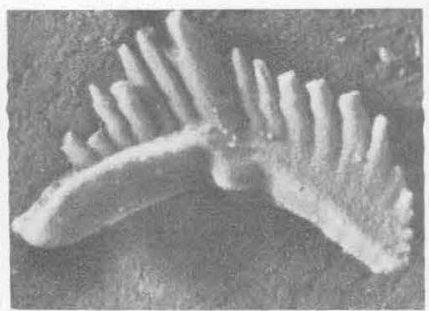

6

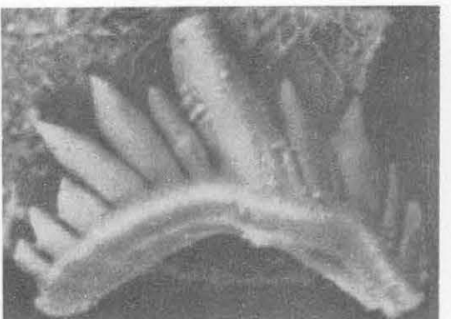

3

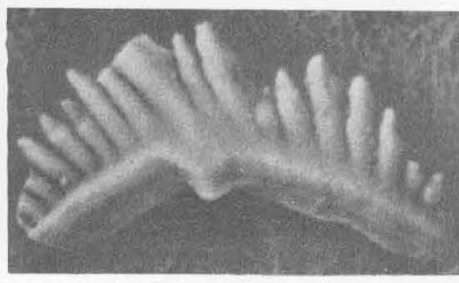

7

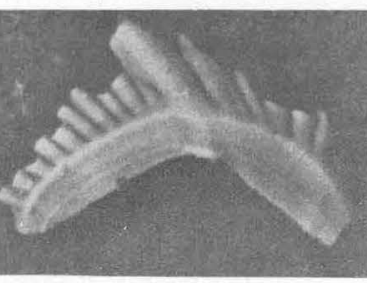

11

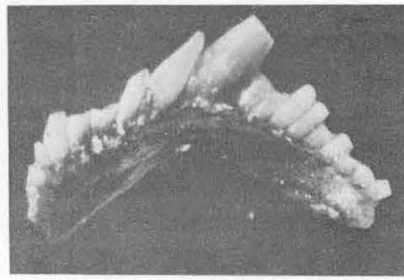

12
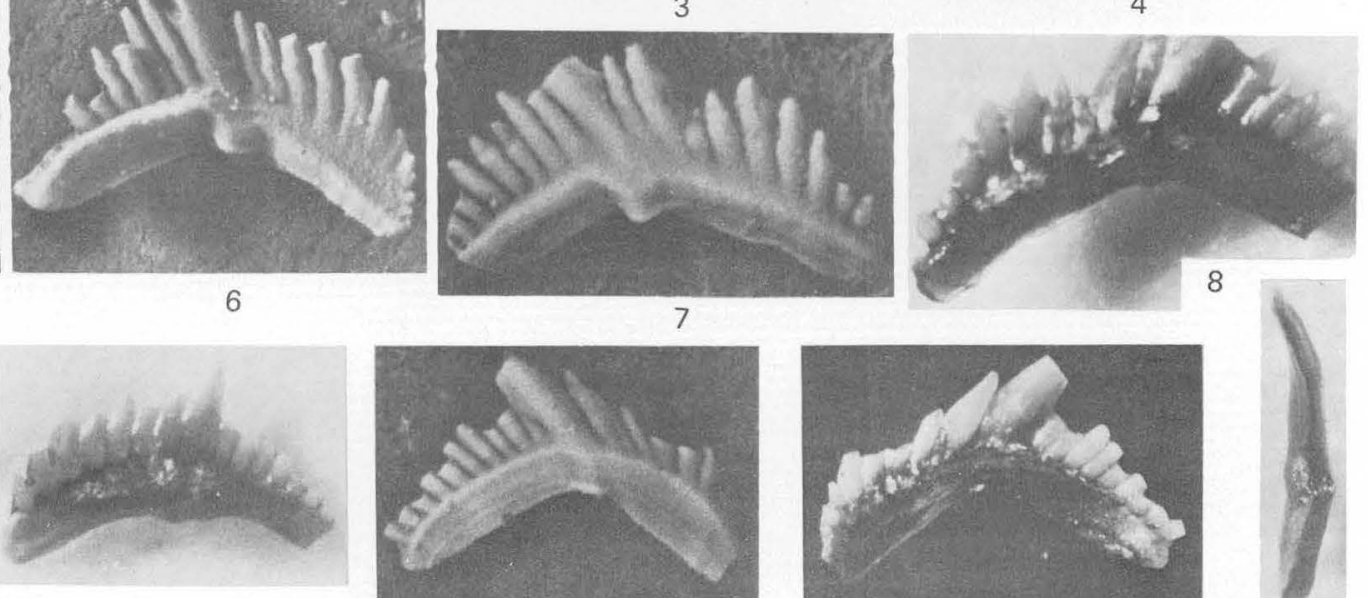

10

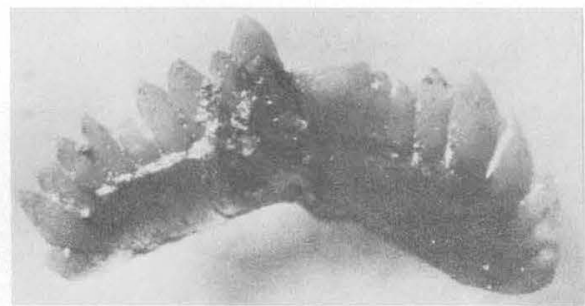

15

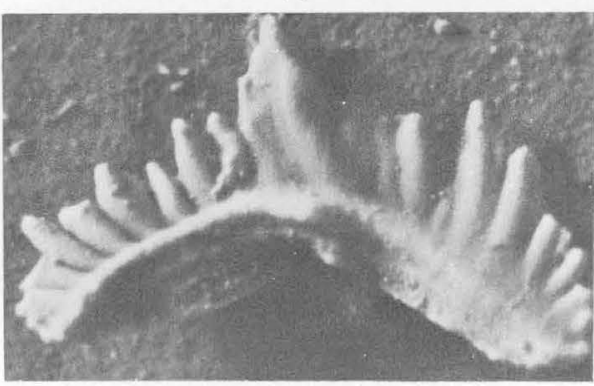

18

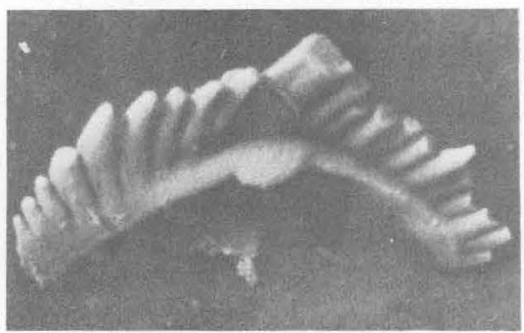

21

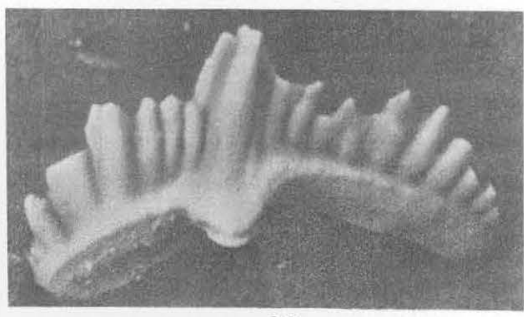

16
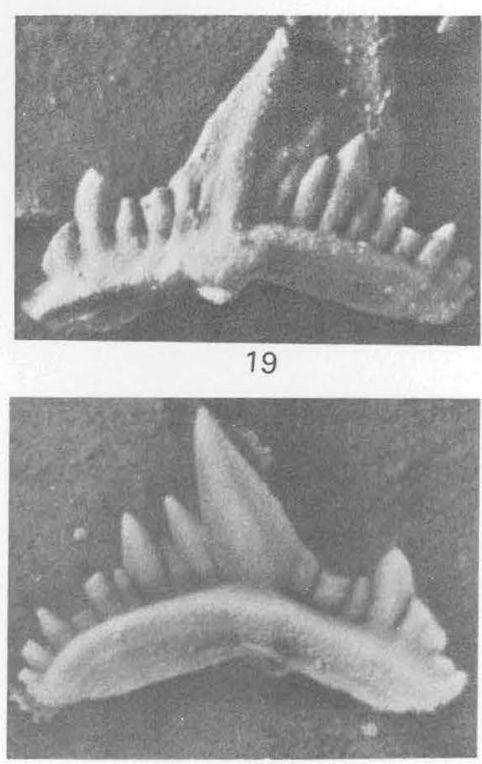

20

BRYANTODUS 


\section{PLATE 22}

[All figures $\times 30$. All specimens uncoated except figs. 13, 15, 21]

FIgURES 1-8. Bryantodus retusus (Bryant) (p. B36).

1,2. Inner and outer views of an immature specimen with white matter continuing into the bar ("denticles inserted"). Note lack of basal expansion. USNM 188876; USGS 4574-SD, Genundewa Limestone Member of Genesee Formation, Elevenmile Creek (At-1).

3,4. Outer and inner views, USNM 188875; USGS 4574-SD, Genundewa Limestone Member of Genesee Formation, Elevenmile Creek (At-1). Note double ridge on basal expansion and inner shelf.

5,6. Outer and inner views, USNM 188851; USGS 8122-SD, West River Shale Member of Genesee Formation, Fall Brook (Cl-4). Note the nodes in inner shelf.

7,8. Outer and inner oblique views, USNM 188881; USGS 4577-SD, Genundewa Limestone Member of Genesee Formation, Cayuga Creek (Dp-3). Shows slight inward bowing and inner boss below the cusp.

9, 10. Ozarkodina lata Bischoff and Ziegler (p. B39).

Outer and inner views, USNM 188847; USGS 6720-SD, Tully Limestone, Voorhys Gully, near (Cd12).

11-24. Bryantodus colligatus (Bryant) (p. B35).

11,12,19. Outer, inner, and aboral views, USNM 188867; USGS 4577-SD, Genundewa Limestone Member of Genesee Formation, Cayuga Creek (Dp-3). Note white matter is confined to denticles and there are nodes on inner ledge.

13-15. Outer, oral, and inner views, USNM 188865; USGS 4526-SD, Genundewa Limestone Member of Genesee Formation, Pike Creek (SC-1). Note the smooth, matte surfaces on the narrow inner and outer ledges.

16-18. Aboral, outer, and oral views, USNM 188873; USGS 4553-SD, Genundewa Limestone Member of Genesee Formation, Cazenovia Creek (Dp-1). Note the lateral ridge on cusp and slight bowing of bar.

20-22. Aboral, inner, and outer views, USNM 188862; USGS 4577-SD, Genundewa Limestone Member of Genesee Formation, Cayuga Creek (Dp-3).

23, 24. Inner and outer views, USNM 188872; USGS 4553-SD, Genundewa Limestone Member of Genesee Gormation, Cazenovia Creek (Dp-1). 
GEOLOGICAL SURVEY

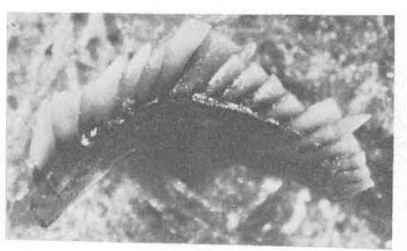

1
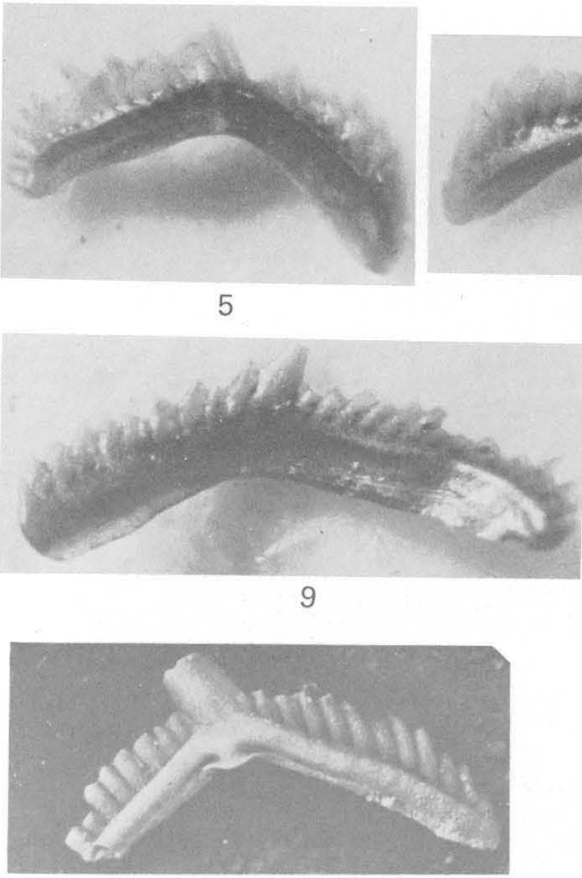

13
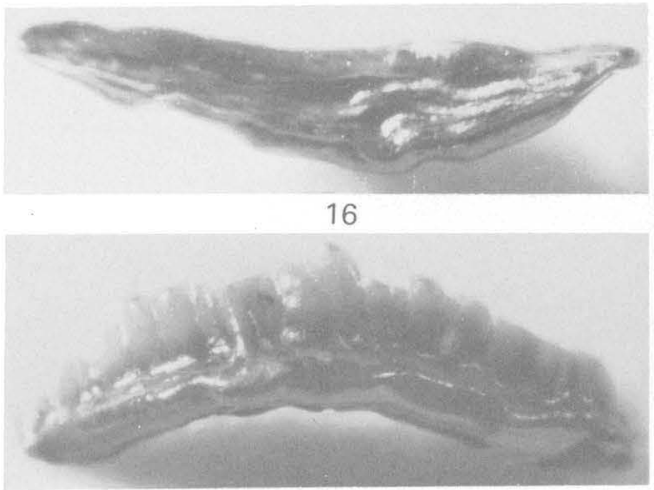

17

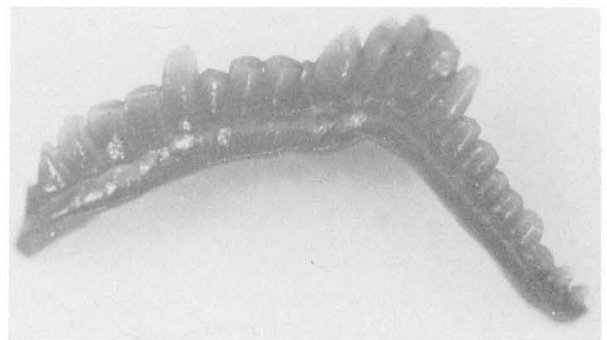

23
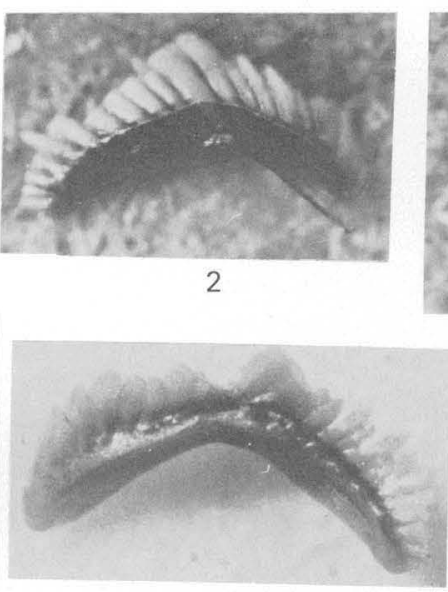

6

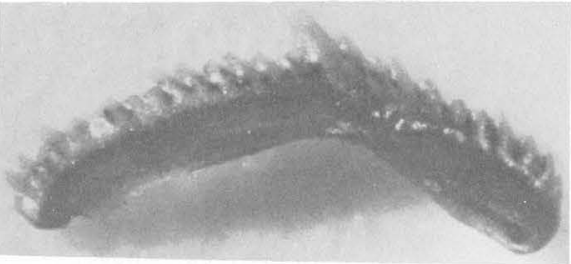

10

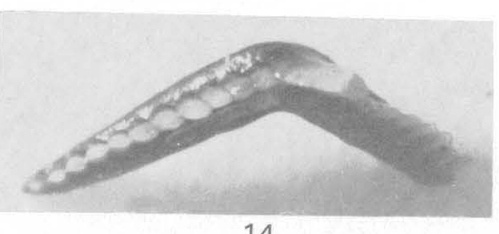

14
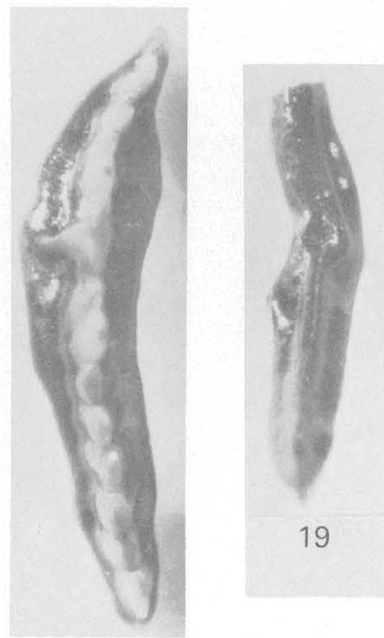

18

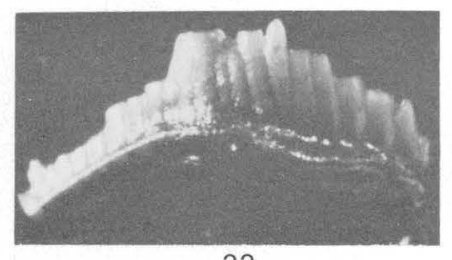

22
PROFESSIONAL PAPER 1032-B PLATE 22
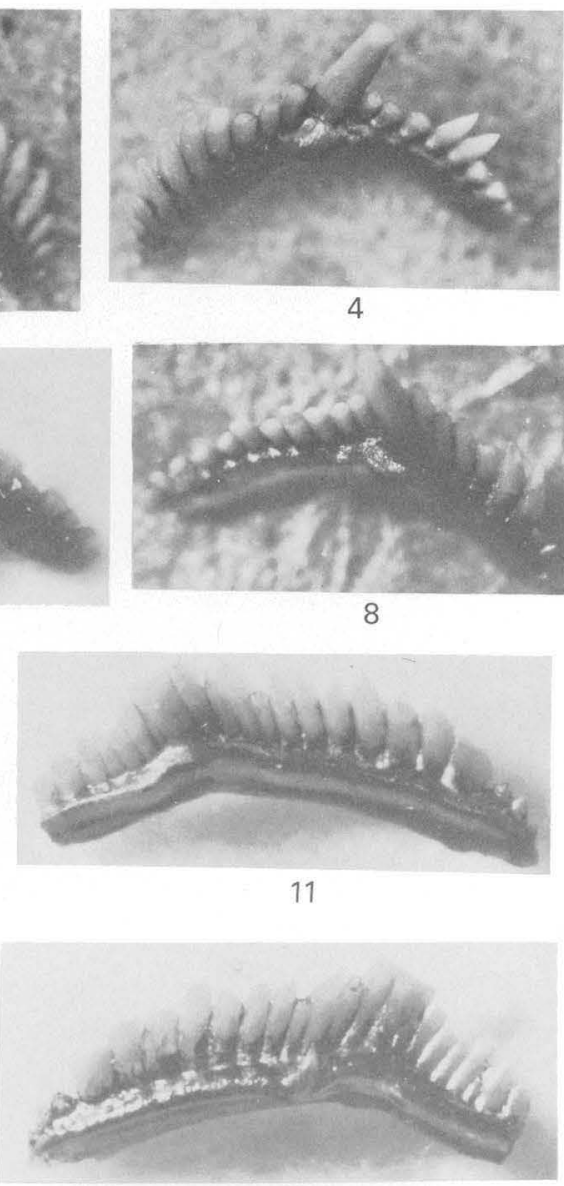

12

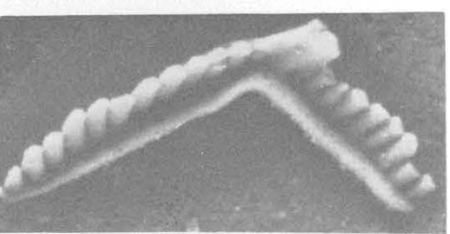

15

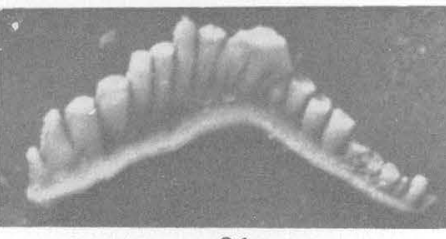

21

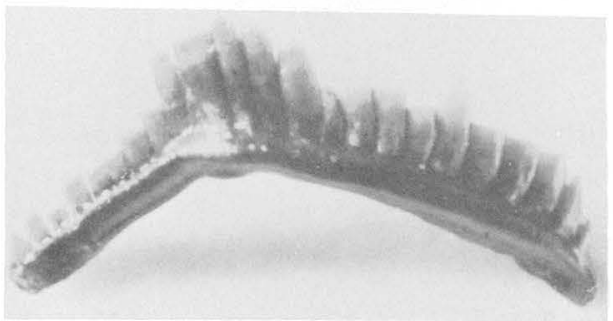

24

BRYANTODUS AND OZARKODINA 


\section{PLATE 23}

[All figures $\times 30$. Figs. 6,7 , coated, others not coated]

Figures 1-9. Neoprioniodus alatus (Hinde) (p. B39).

1,2. Inner and outer views showing distribution of white matter. USNM 189002; USGS 8122-SD, West River Shale Member of Genesee Formation, Fall Brook (Cl-4).

3, 4. Outer and inner views, USNM 189003; USGS 4586-SD, Genundewa Limestone Member of Genesee Formation, Taunton Gully (Cl-2). Faint denticles indicated by white matter in anticusp.

5,6. Outer and inner views, uncoated and coated, USNM 189004; USGS 4577-SD, Genundewa Limestone Member of Genesee Formation, Cayuga Creek (Dp-3).

7. Outer view, USNM 188959; USGS 4574-SD, Genundewa Limestone Member of Genesee Formation, Elevenmile Creek (At-1).

8,9. Outer and inner views, USNM 188905; USGS 6774-SD, Penn Yan Shale Member of Genesee Formation, Hubbard quarry (Gen-2). Shows discrete denticles on the anticusp.

10-17. Neoprioniodus armatus (Hinde) (p. B39).

10,11. Outer and inner views, USNM 189006; USGS 8122-SD, West River Shale Member of Genesee Formation, Fall Brook (Cl-4). Note that the white matter is more distinct than in N. alatus.

12,13. Outer and inner views, USNM 189007; USGS 6718-SD, Penn Yan Shale Member of Genesee Formation, Genundewa Point (Nap-4).

14,15. Inner and outer views, USNM 189008; USGS 8973-SD, West River Shale Member of Genesee Formation, Eighteenmile Creek (Ed-1). Note free denticle on anticusp.

16,17. Inner and outer views, USNM 189009; USGS 4553-SD, Genundewa Limestone Member of Genesee Formation, Cazenovia Creek (Dp-1). Note crowded denticles.

18, 19. Synprioniodina alternata Bassler (p. B40).

Outer and inner views, USNM 189012; USGS 8961-SD, Genundewa Limestone Member of Genesee Formation, Dewey Hill (Cl-5). 
GEOLOGICAL SURVEY

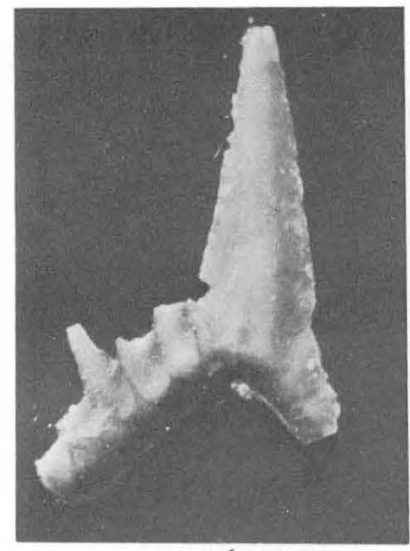

1

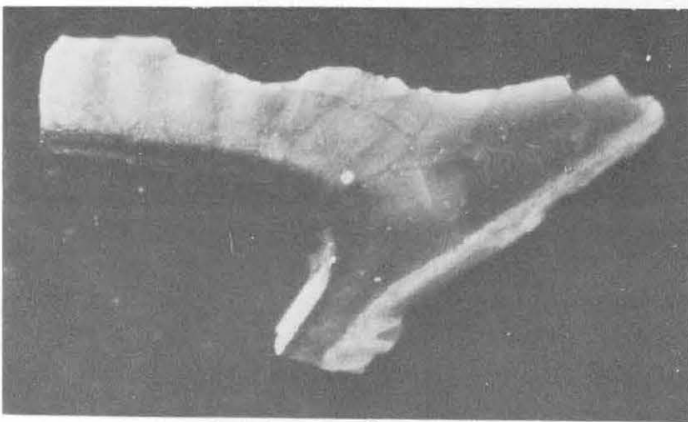

5

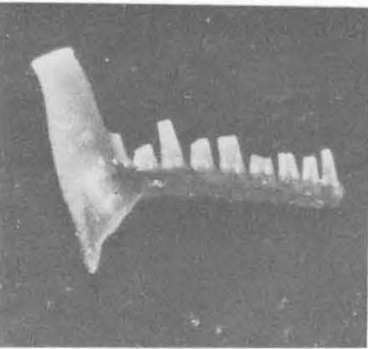

11

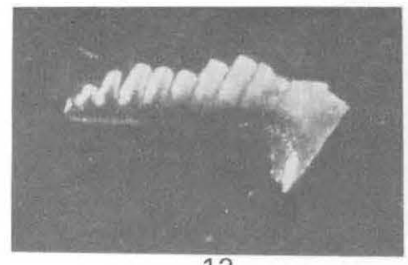

12

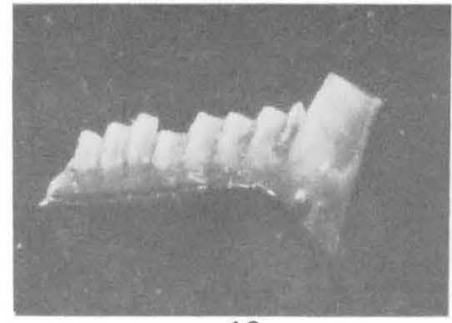

16
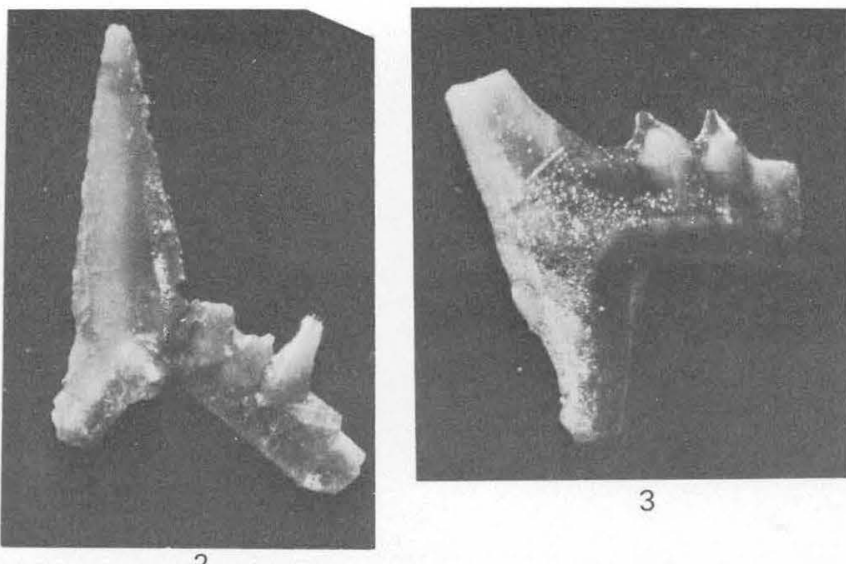

3
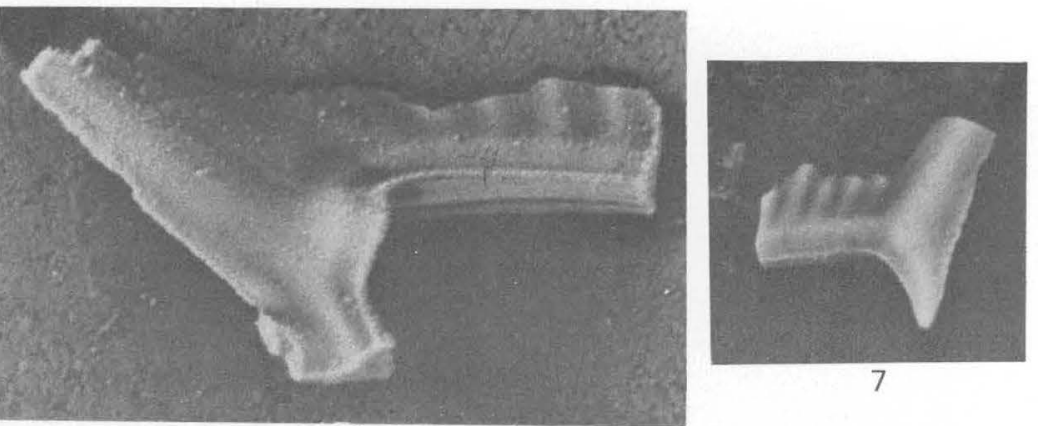

6

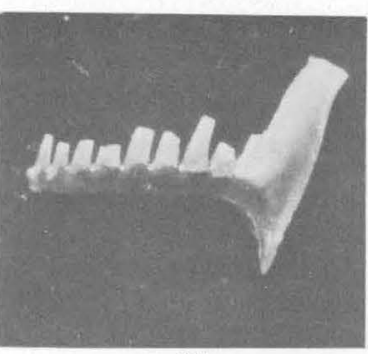

10

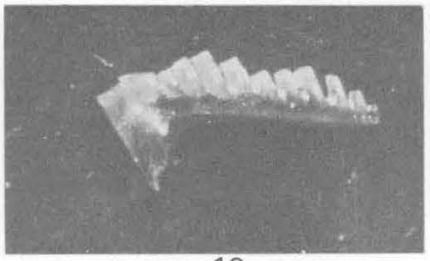

13

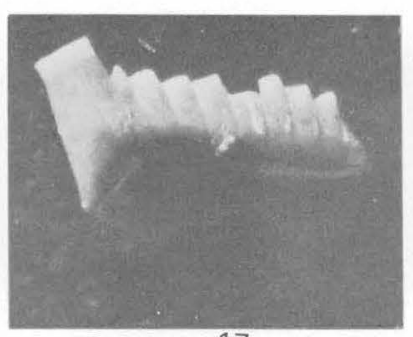

17

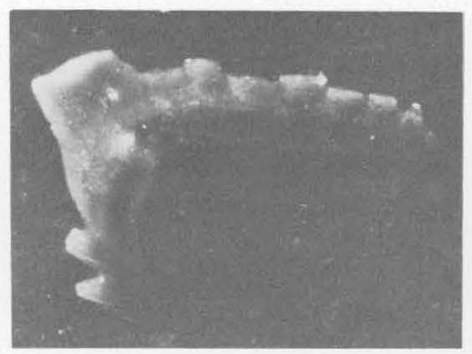

9

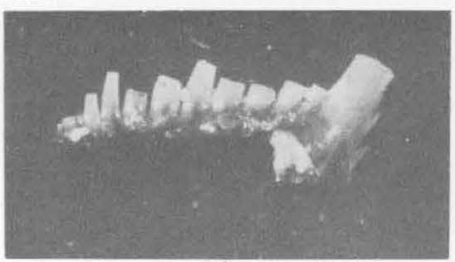

14

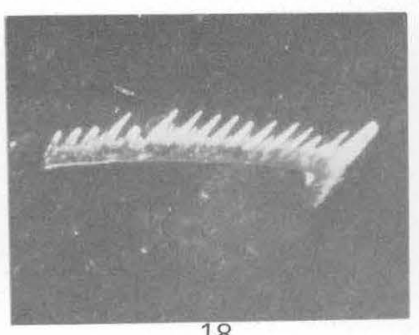

18

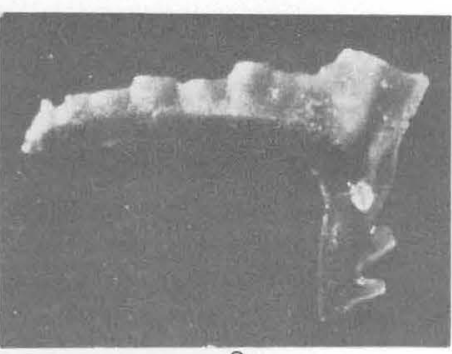

8

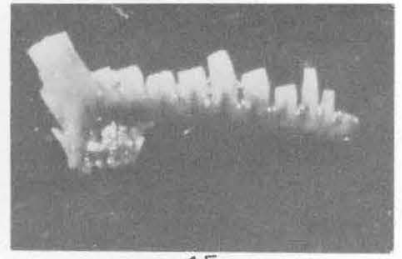

15

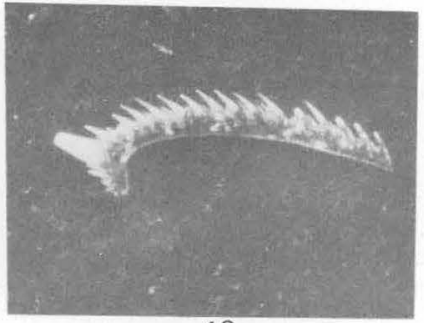

19

NEOPRIONIODUS AND SYNPRIONIODINA 


\section{PLATE 24}

[All figures $\times 30$. Figs. 8, 10 coated, others not coated]

Figures 1-5, 8-11, 14, 15. Hindeodella angulus Huddle (p. B42).

1,2. Outer and inner views, USNM 188824; USGS 4586, Genundewa Limestone Member of Genesee Formation, Taunton Gully (Cl-2).

3-5. Outer, inner, and aboral views, USNM 188831; USGS 4546-SD, Genundewa Limestone Member of Genesee Formation, Pike Creek (SC-1). The posterior bar is broken. Note basal pit and continuous curve of bar and anticusp without off set.

8, 9. Outer and inner views, USNM 188834; USGS 4586-SD, Genundewa Limestone Member of Genesee Formation, Taunton Gully (Cl-2).

$.10,11$. Outer and inner views, USNM 188822; USGS 4576-SD, Penn Yan Shale Member of Genesee Formation, Cayuga Creek ( $\mathrm{Dp}-3)$.

14,15 . Outer and inner views of a large specimen with a broken posterior bar, USNM 188836 ; USGS 8122-SD, West River Shale Member of Genesee Formation, Fall Brook (Cl-4).

6, 7, 12, 13, 18, 19. Hindeodella alternata Ulrich and Bassler (p. B41).

6 , 7. Inner and outer views, USNM 188823; USGS 8122-SD, West River Shale Member of Genesee Formation, Fall Brook (Cl-4).

12,13. Inner and outer views, USNM 188821; USGS 8122-SD, West River Shale Member of Genesee Formation, Fall Brook (Cl-4).

18,19. Outer and inner views, USNM 188832; USGS 7619-SD, Genundewa Limestone Member of Genesee Formation, Clover Bank quarry (Ed-2).

16,17. Hindeodella curvidens Cooper [not discussed in text].

Outer and inner views showing strong twist of the bar and large basal pit. USNM 188830; USGS 6733-SD, Tully Limestone, Gage Gully (Cd-12). 
GEOLOGICAL SURVEY

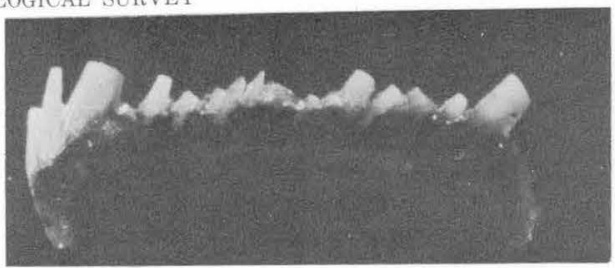

1

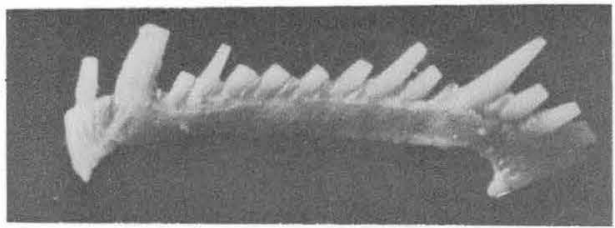

7

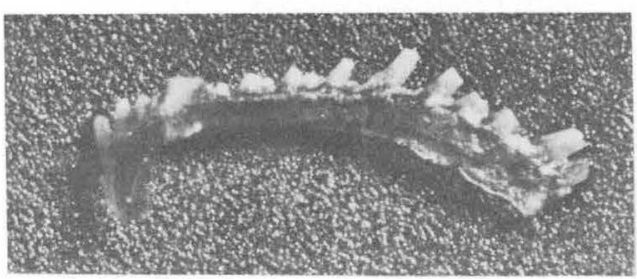

8

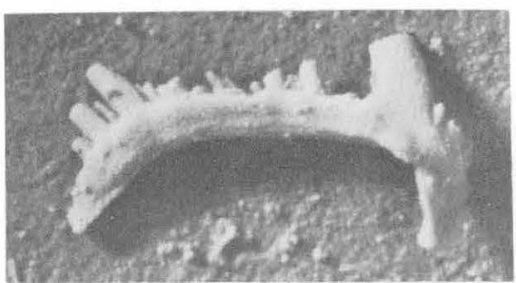

10

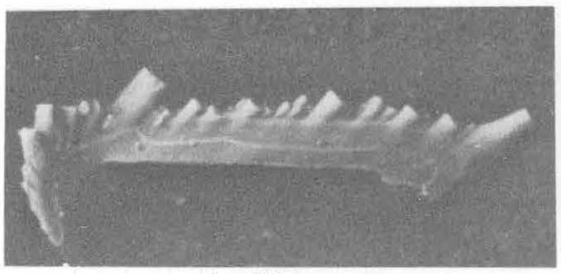

12

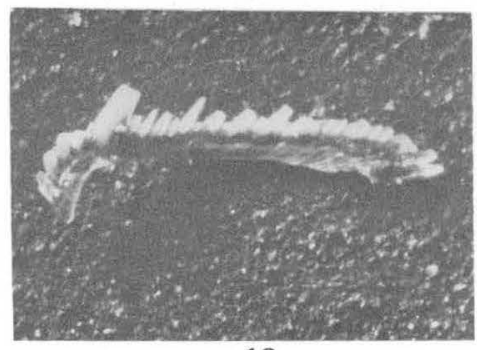

18

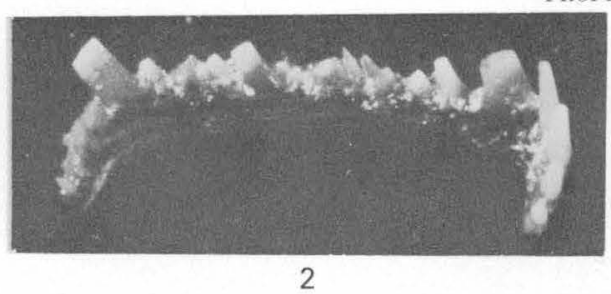

2

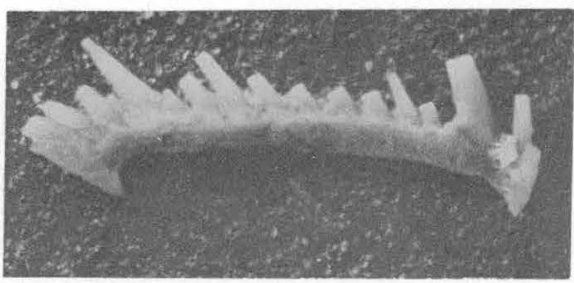

6

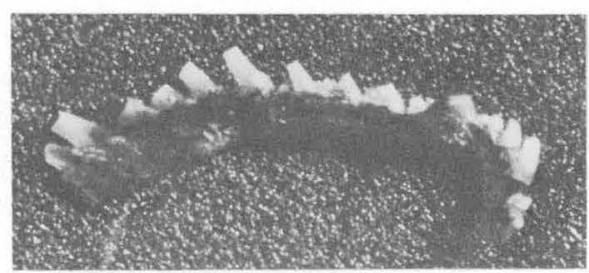

9

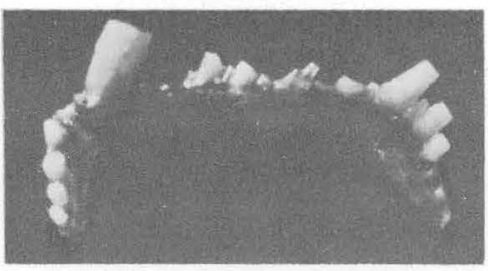

11

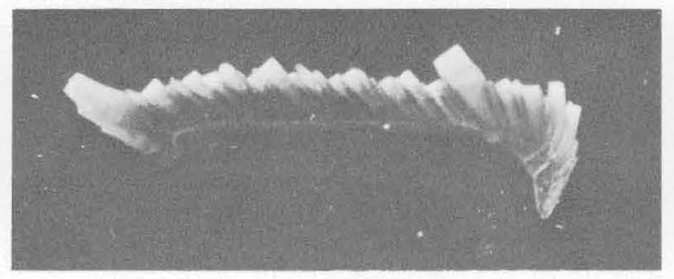

13

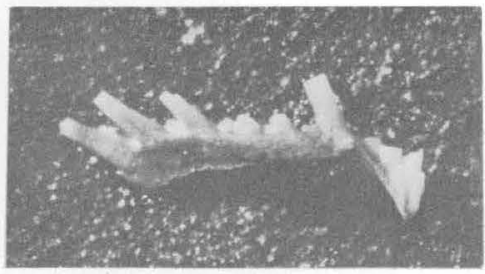

17

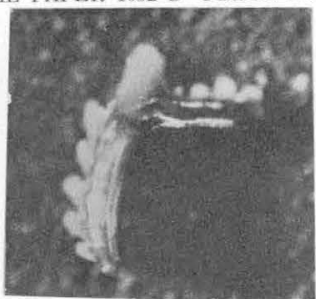

3

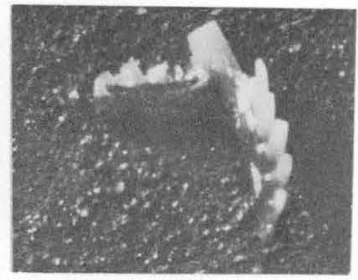

4

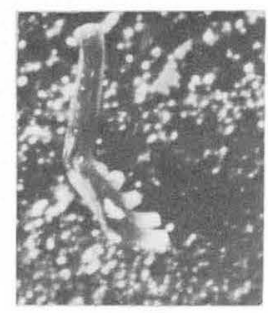

5

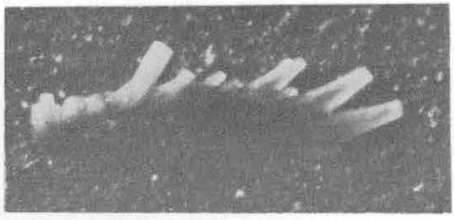

16

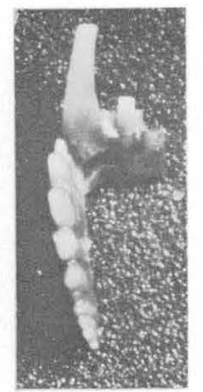

15

HINDEODELLA 


\section{PLATE 25}

[All figures $\times 30$. All specimens uncoated except fig. 20]

FIGURES

1;2. Hindeodella subtilis Ulrich and Bassler (p. B42).

Inner and outer views, USNM 188828; USGS 6737; Genundewa Limestone Member of Genesee Formation, Eighteenmile Creek (Ed-1).

3, 4, 7-9. Hindeodella elongata Huddle (p. B42).

3. Outer view young specimen, USNM 188833; USGS 8961-SD, Genundewa Limestone Member of Genesee Formation, Dewey Hill (Cl-5).

4. Outer view, USNM 188826; USGS 4544-SD, Genundewa Limestone Member of Genesee Formation, Eighteenmile Creek (Ed-1).

7-9. Inner, outer, and aboral views, USNM 188827; USGS 8957-SD, West River Shale Member of Genesee Formation, Chidsey Point (Py-7).

5,6. Hindeodella compressa Huddle (p. B42).

Inner and outer views, USNM 188829; USGS 4544-SD, Genundewa Limestone Member of Genesee Formation Eighteenmile Creek (Ed-1).

10,11, 14, 16-20. Angulodus demissus Huddle (p. B41).

10,11. Outer and inner views, USNM 188994; USGS 4586-SD, Genundewa Limestone Member of Genesee Formation, Taunton Gully (Cl-2).

14. Inner view, USNM 188996; USGS 8970-SD, Genundewa Limestone Member of Genesee Formation, Bethany Center (Ba-3).

16,17. Outer and inner views, USNM 188997; USGS 4553-SD, Genundewa Limestone Member of Genesee Formation, Cazenovia Creek (Dp-1).

18, 19. Inner and outer views, USNM 188995; USGS 4526-SD, Genundewa Limestone Member of Genesee Formation, Pike Creek (SC-1).

20. Outer view, USNM 188993; USGS 4596-SD, Genundewa Limestone Member of Genesee Formation, Bethany Center (Ba-3).

12,13,15. Hindeodella angulus Huddle (p. B42).

12, 13. Inner and outer views of broken specimen showing the larger denticle size and anticusp than that of $H$. subtilis. USNM 188835; USGS 4586-SD, Genundewa Limestone Member of Genesee Formation, Taunton Gully (Cl-2).

15. Aboral view, USNM 188836; USGS 8122-SD, West River Shale Member of Genesee Formation, Fall Brook (Cl-4). See pl. 24, figs. 14, 15, for other views. 


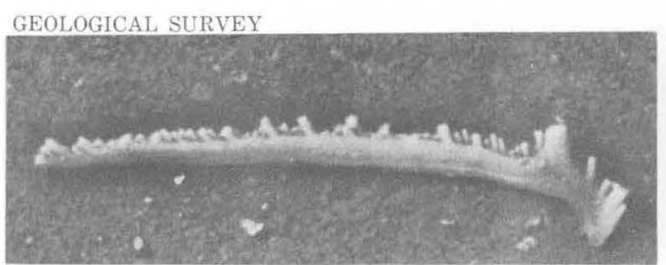

1

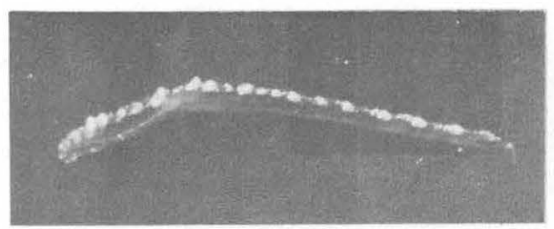

4

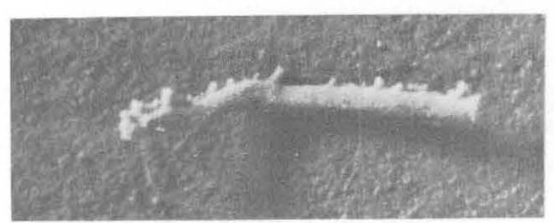

7

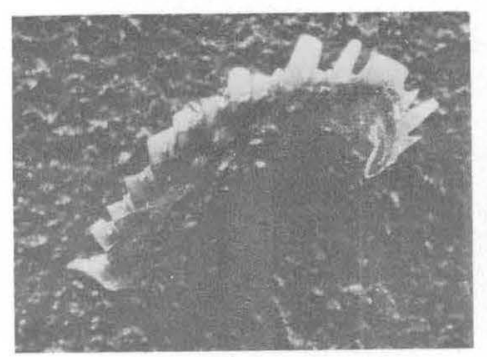

10

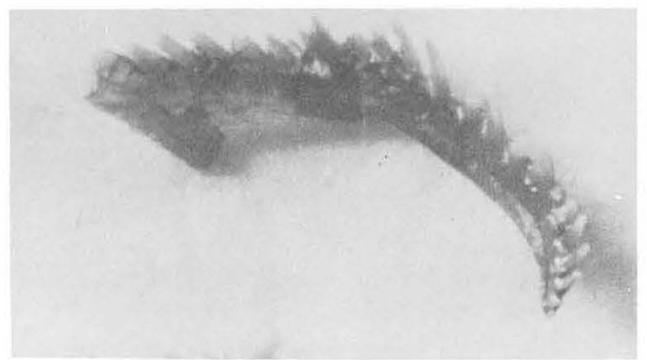

14

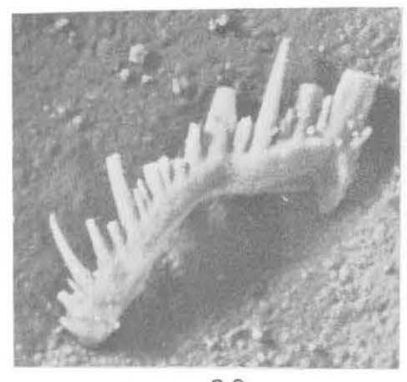

20

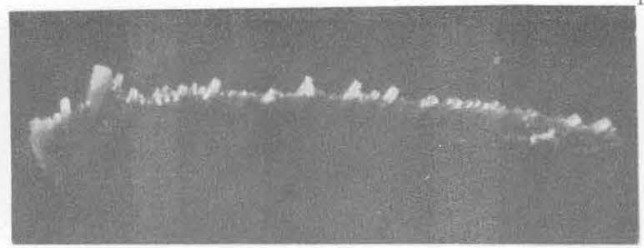

2

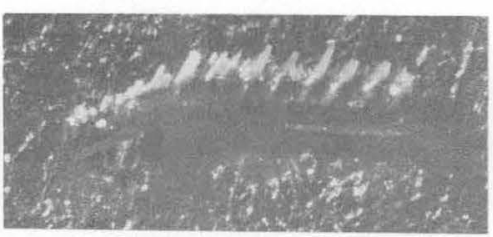

5

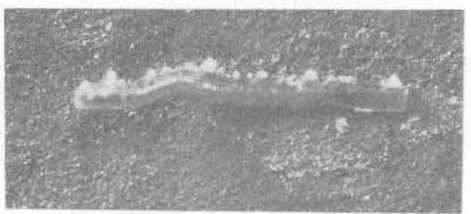

8

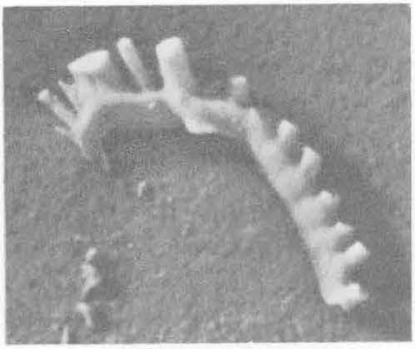

11

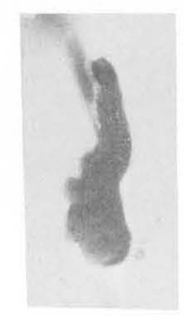

15

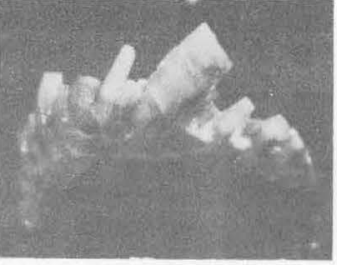

12

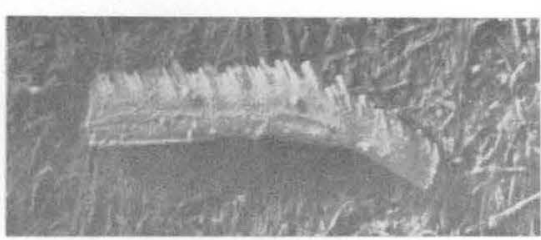

6

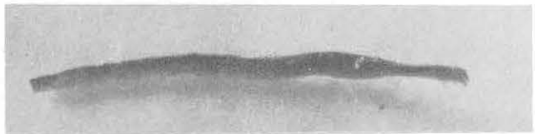

9

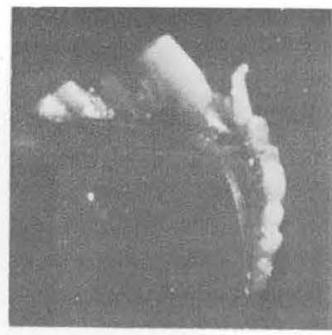

13
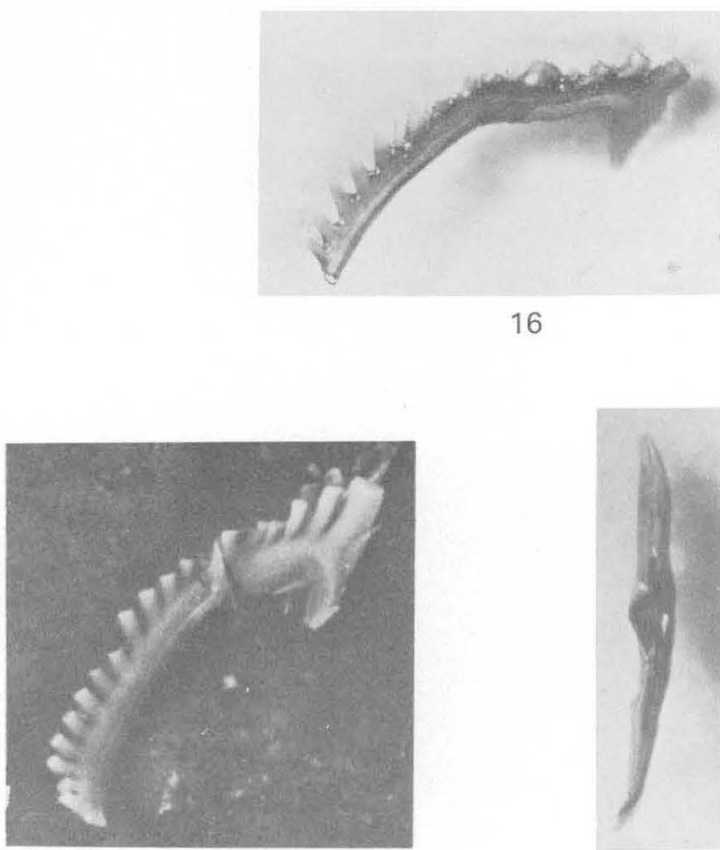

18

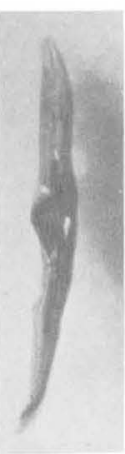

17

HINDEODELLA AND ANGULODUS 


\section{PLATE 26}

[All figures $\times 30$ except figs. 13,14,20 $\times 20$. Figs. 1-3,13,14, 20 coated; others not coated]

Figures 1,2. Bryantodus retusus (Bryant) (p. B36).

North Evans Limestone of Rickard (1964), Eighteenmile Creek (Ed-1). Both specimens are broken, and the outside is partly covered.

1. Inner view, USNM 135021; lectotype figured by Bryant (1921, pl. 4, fig. 8). There is a strong basal projection on outside below cusp.

2. Inner view, USNM 135029, syntype figured by Bryant (1921, pl. 5, fig. 9).

3. Bryantodus colligatus (Bryant) (p. B35).

Outer view of lectotype, USNM 142768, figured by Bryant (1921, pl. 5, fig. 10) ; North Evans Limestone of Rickard (1964), Eighteenmile Creek (Ed-1). Inside bar typical of species and partly concealed.

4. Angulodus demissus Huddle (p. B41).

Outer view, USNM 188996; USGS 8970-SD, Genundewa Limestone Member of Genesee Formation, Bethany Center (Ba-3).

5-10. Ozarkodina lata Bischoff and Ziegler (p. B39).

5-7. Inner, outer, and aboral views, USNM 188817; USGS 9070-SD, Tully Limestone, Tinker Falls $(\mathrm{Tu}-2)$.

8-10. Inner, outer, and aboral views, USNM 188818; USGS 9070-SD, Tully Limestone, Tinker Falls $(\mathrm{Tu}-2)$.

11-14. Enantiognathus? guntharii (Ziegler) (p. B40).

11,12. Outer and inner views, USNM 188954; USGS 4553-SD, North Evans Limestone of Rickard (1964), Cazenovia Creek (Dp-1).

13, 14. Large specimen from R. R. Hibbard Colln., UMMP 60873, Genundewa Limestone Member of Genesee Formation, Amsdell Creek, N.Y.

15-20. Enantiognathus lipperti. (Bischoff) (p. B39).

15, 16. Element with three bars, oblique-oral and aboral views, USNM 188964; USGS 4586-SD, Genundewa Limestone Member of Genesee Formation, Taunton Gully (Cl-2).

17, 18. Oblique-oral and aboral views of another form with three bars, USNM 188952; USGS 6715SD, Penn Yan Shale Member of Genesee Formation (Nap-4).

19. Typical form with two bars, USNM 188963; USGS 4586-SD, Genundewa Limestone Member of Genesee Formation, Taunton Gully (Cl-2).

20. Inner-oblique view, UMMP 60850, R. R. Hibbard Colln., North Evans Limestone of Rickard (1964), Amsdell Creek, N.Y.

21-23. Enantiognathus sp. [not discussed in text].

21, 22. Inner-oblique and aboral-oblique views, USNM 188968; USGS 4535-SD, Genundewa Limestone Member of Genesee Formation, Eighteenmile Creek (Ed-1).

23. Outer view, USNM 188966; USGS 4578-SD, Genundewa Limestone Member of Genesee Formation, Cayuga Creek ( $\mathrm{Dp}-3)$. This specimen does not have alternating denticles. 
GEOLOGICAL SURVEY

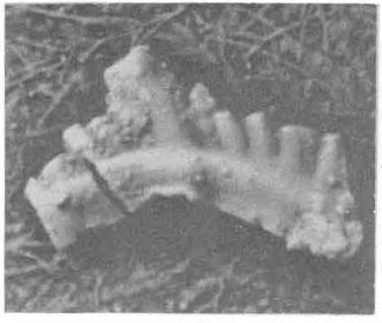

1

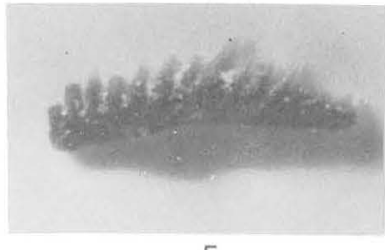

5

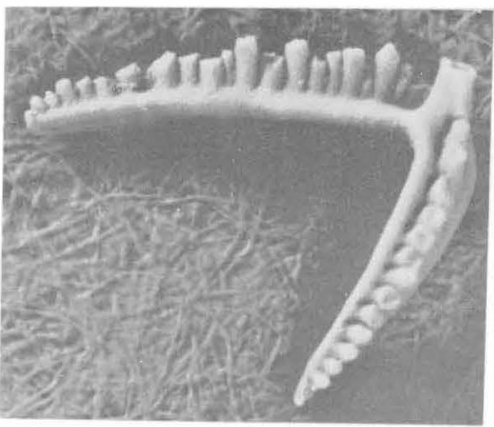

13

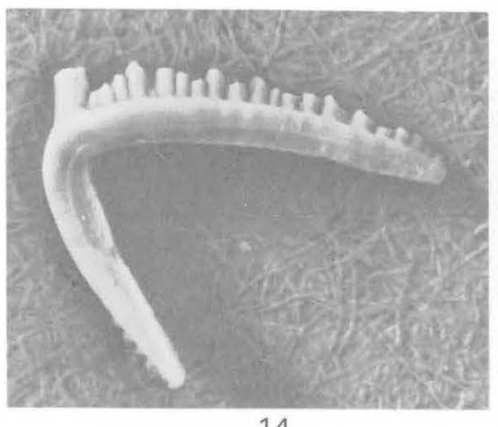

14

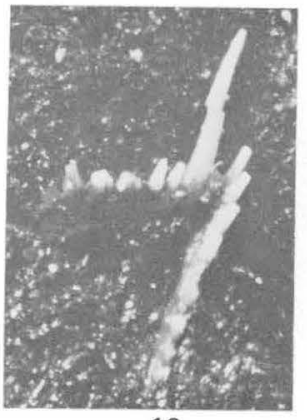

19

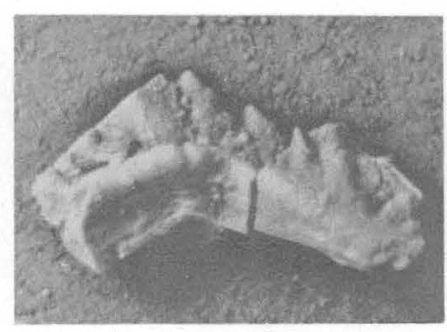

2

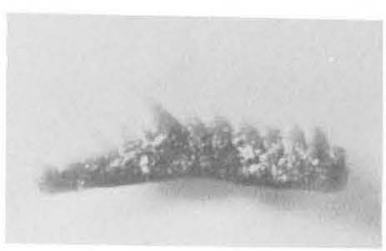

6

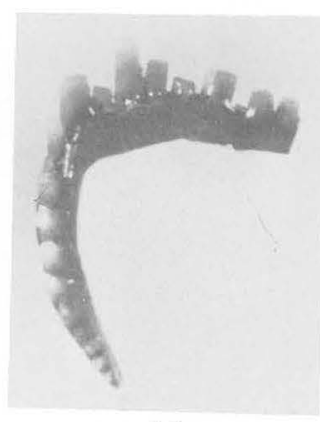

12

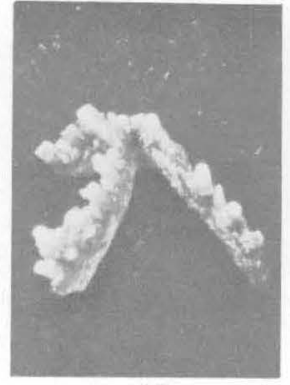

15

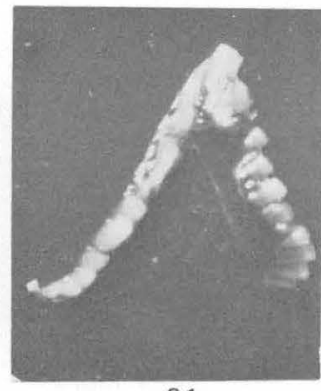

21

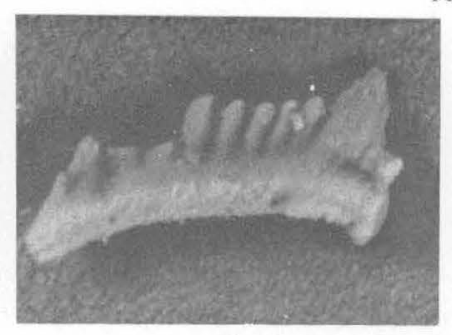

3

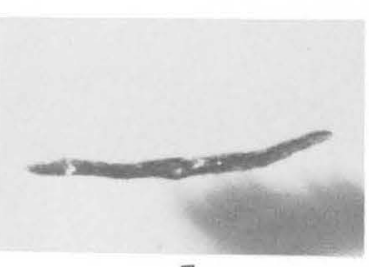

7

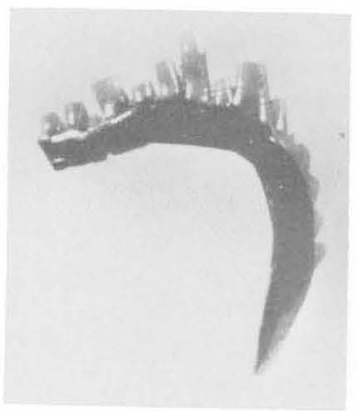

11
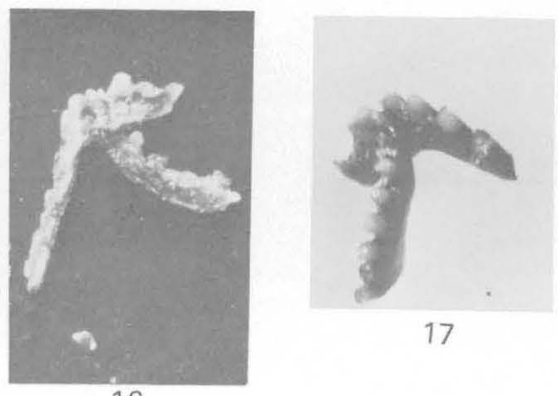

16
PROFESSIONAL PAPER 1032-B PLATE 26
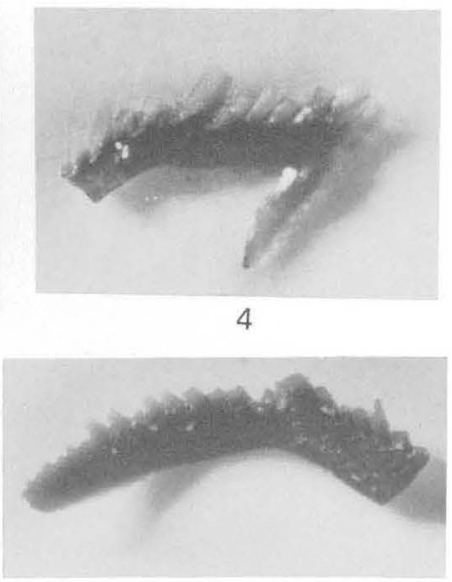

8
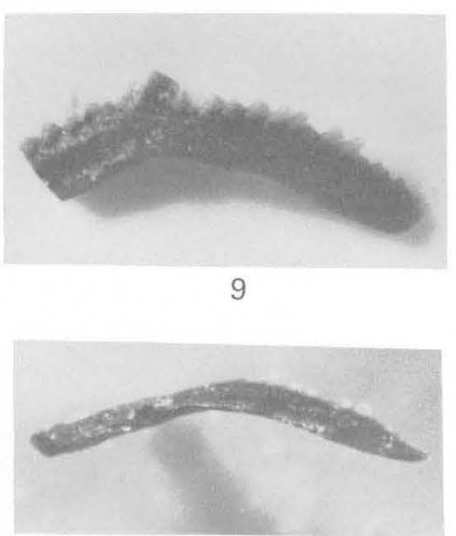

10
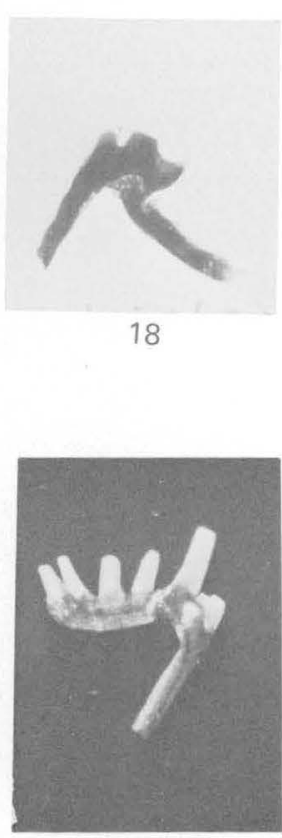

23

BRYANTODUS, ANGULODUS, OZARKODINA, AND ENANTIOGNATHUS 


\section{PLATE 27}

[All figures $\times 30$. Figs. 7, 8, 10 and 13 coated; others not coated]

Figures 1,2. Enantiognathus? guntharii (Ziegler) (p. B40).

Outer and inner views juvenile specimen, USNM 188955; USGS 8122-SD, West River Shale Member of Genesee Formation, Fall Brook (Cl-4).

3,4. Enantiognathus lipperti (Bischoff) (p. B39).

Outer and inner views, USNM 188970; USGS 3952-SD, Genundewa Limestone Member of Genesee Formation, Genundewa Point (Nap-4).

5,6. Enantiognathus sp. [not discussed in text].

Inner and outer views, USNM 188984; USGS 4586-SD, Genundewa Limestone Member of Genesee Formation, Taunton Gully (Cl-2).

7-15. Ligonodina panderi (Hinde) (p. B44).

7. Inner view, USNM 188971; USGS 8122-SD, West River Shale Member of Genesee Formation, Fall Brook (Cl-4).

8. Inner view large specimen, USNM 188972; USGS 3952-SD, Genundewa Limestone Member of Genesee Formation, Genundewa Point (Nap-4).

9. Inner view of nearly complete specimen, USNM 188965; USGS 8961-SD, Genundewa Limestone Member of Genesee Formation, Dewey Hill (Cl-5).

10. Outer view, USNM 188969; USGS 8122-SD, West River Shale Member of Genesee Formation, Fall Brook (Cl-4).

11,12. Outer and inner views, USNM 188979; USGS 8122-SD, West River Shale Member of Genesee Formation, Fall Brook ( $\mathrm{Cl}-4)$. Note the repaired or rejuvenated denticles.

13. Inner view, USNM 188967; USGS 4567-SD, Penn Yan Shale Member of Genesee Formation, Elevenmile Creek (At-1).

14,15. Inner and outer views, USNM 188980; USGS 8122-SD, West River Shale Member of Genesee Formation, Fall Brook (Cl-4). Note the slightly curved bar.

16-21. Ligonodina acuta Branson and Mehl (p. B44).

16-18. Aboral, outer, and inner views, USNM 188975; USGS 8970-SD, Genundewa Limestone Member of Genesee Formation, Bethany Center $(\mathrm{Ba}-3)$. Note large basal cavity.

19-21. Inner, aboral, and outer views, USNM 188976; USGS 6754-SD, West River Shale Member of Genesee Formation, Chidsey Point ( $\mathrm{Py}-7)$. 

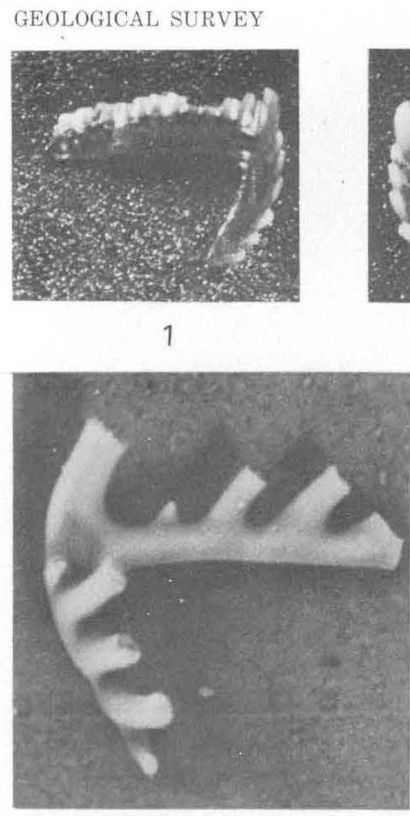

7

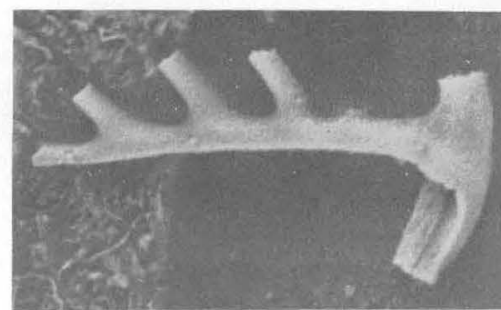

10

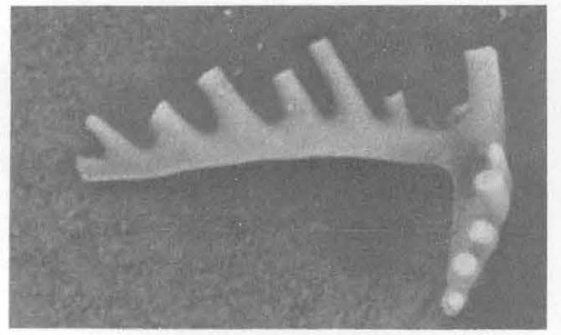

13

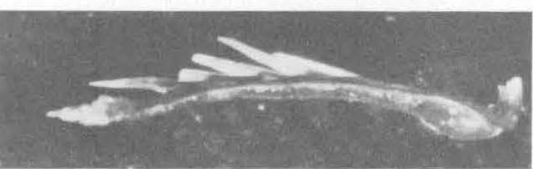

16

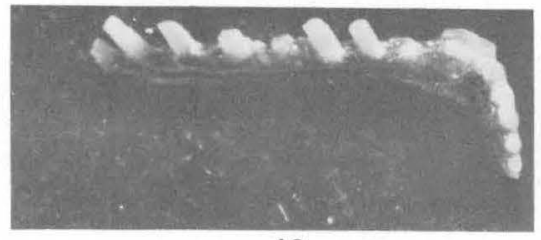

19

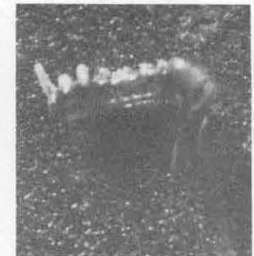

3
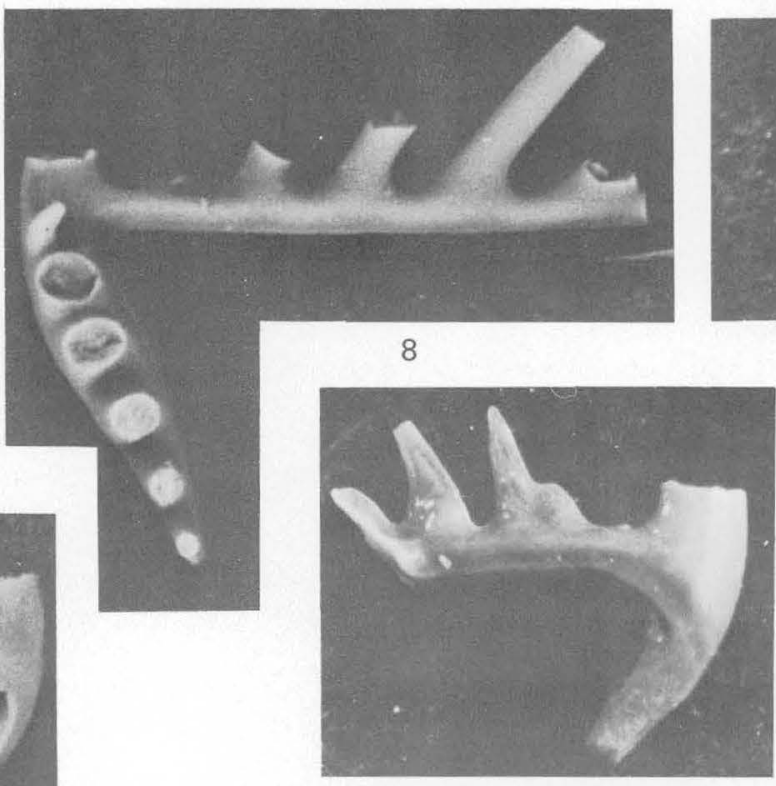

11

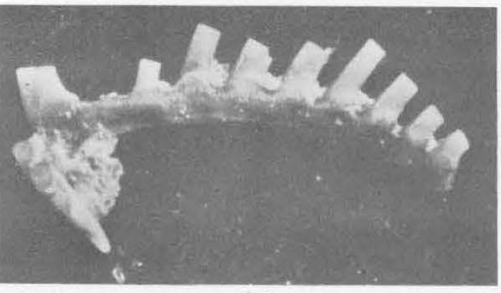

14

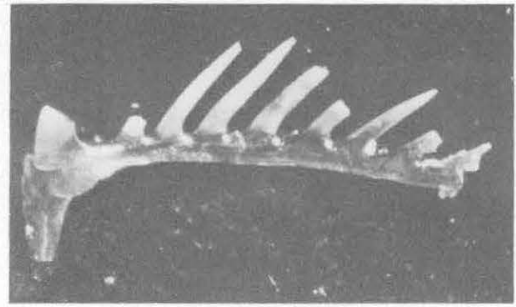

17

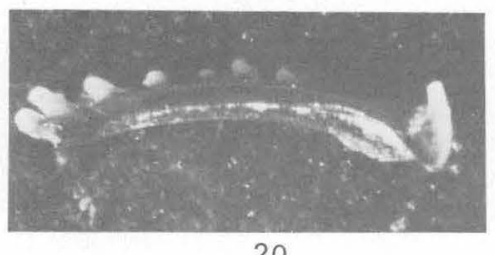

20
PROFESSIONAL PAPER 1032-B PLATE 27
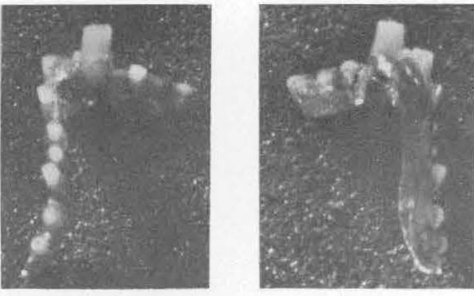

6

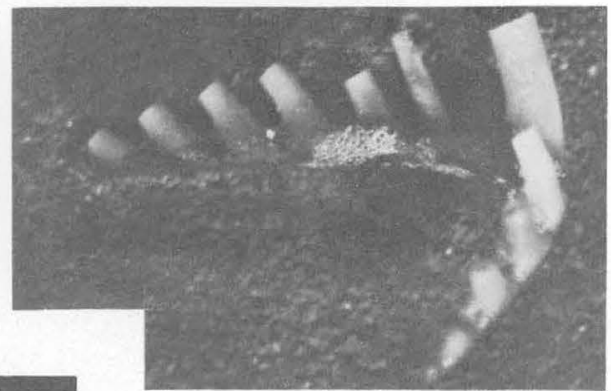

9

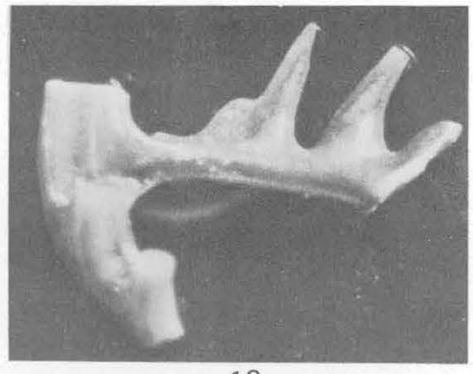

12

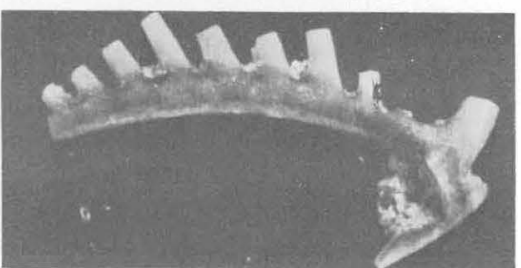

15

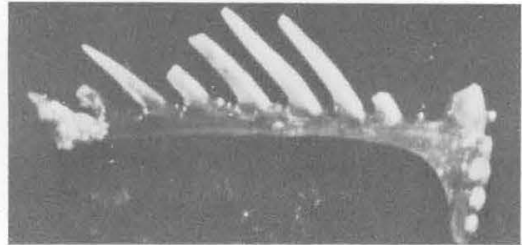

18

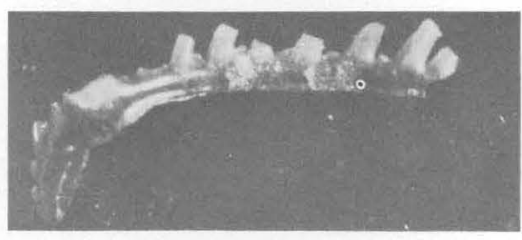

21

ENANTIOGNATHUS AND LIGONODINA 


\section{PLATE 28}

[Figs. 1-11 $\times$ 30; figs. 12-17 $\times$ 20. Figs. 1-11 not coated; figs. 12-17 coated]

Figures 1-11. Ligonodina spicata (Hinde) (p. B44).

1-3. Inner, aboral, and outer views, USNM 188962; USGS 4576-SD, Penn Yan Shale Member of Genesee Formation, Cayuga Creek ( $\mathrm{Dp}-3)$. Note the strong off set of the anticusp and the deep basal pit.

4,5. Inner and outer views, USNM 188977; USGS 4574-SD, Genundewa Limestone Member of Genesee Formation, Elevenmile Creek (At-1).

6,7. Inner and outer views, USNM 188974; USGS 3958-SD, Genundewa Limestone Member of Genesee Formation, Genundewa Point (Nap-4).

8,9. Inner and outer views, USNM 188978; USGS 8122-SD, West River Shale Member of Genesee Formation, Fall Brook (Cl-4).

10,11. Outer and inner views, USNM 188961; USGS 4544-SD, Genundewa Limestone Member of Genesee Formation, Eighteenmile Creek (Ed-1). Juvenile specimen.

12-17. Prioniodina macrodenta (Bryant) (p. B46).

All specimens from the R. R. Hibbard Colln., University of Michigan, Paleontology Museum, North Evans Limestone of Rickard (1964), Amsdell Creek.

12,13. Oblique outer and oral views, UMMP 60874. Gerontic individual.

14. Oblique-inner view, UMMP 60876. Note the pustulose inner platform and fused anterior and discrete posterior denticles.

15. Oblique view, UMMP 60877. Lacks pustules on the platform.

16,17 . Aboral and inner views, UMMP 60875. 
GEOLOGICAL SURVEY

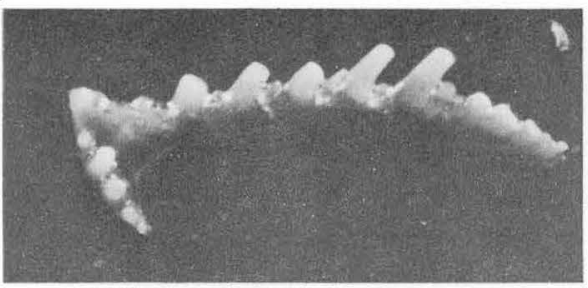

1

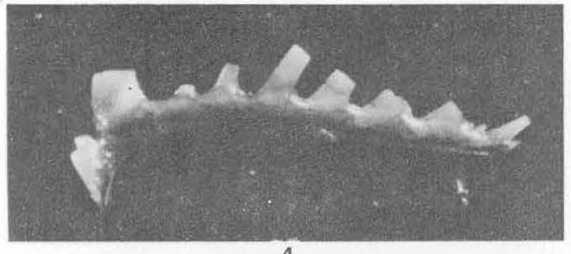

4

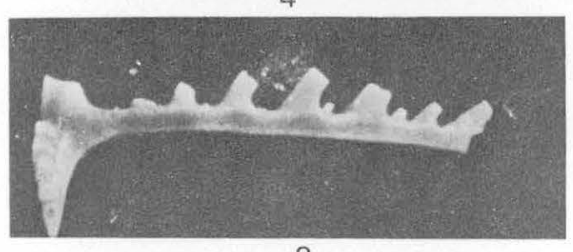

8

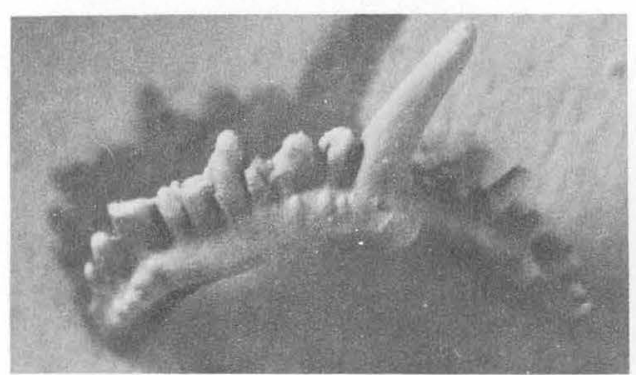

12

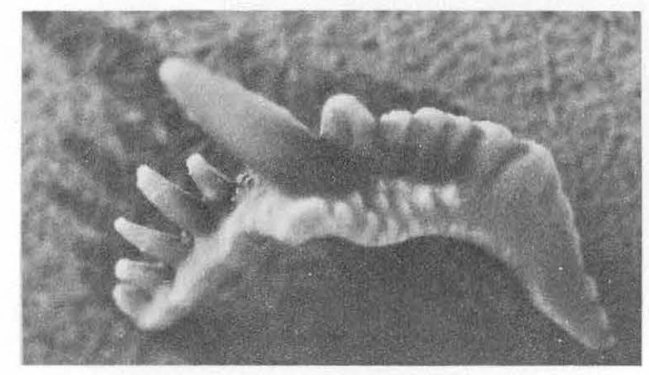

14

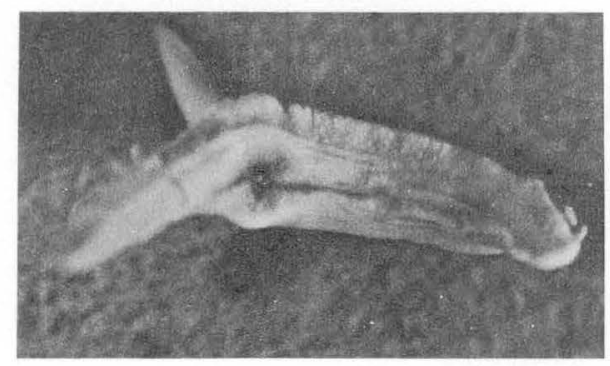

16
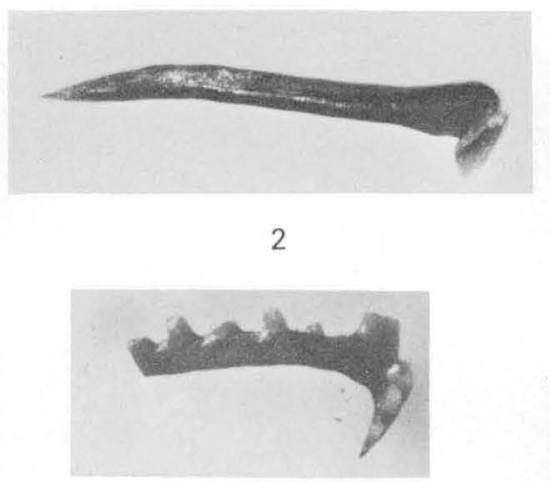

6
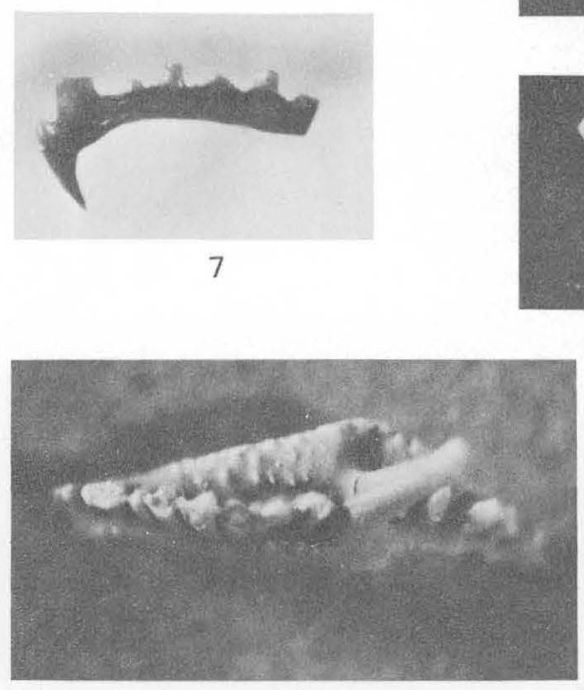

13

PROFESSIONAL PAPER 1032-B PLATE 28

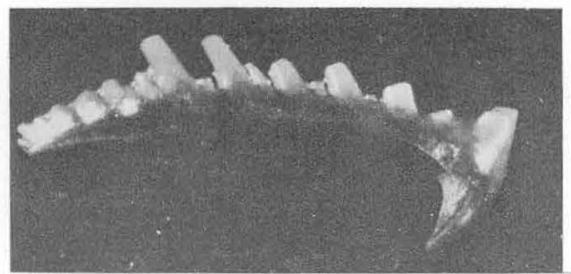

3

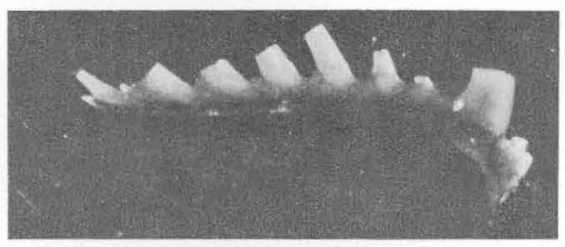

5

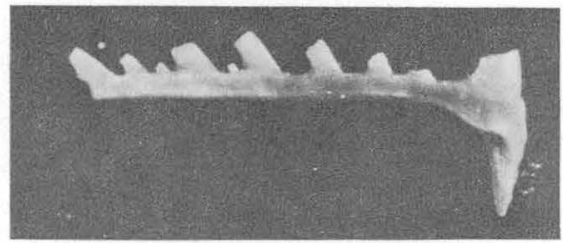

9

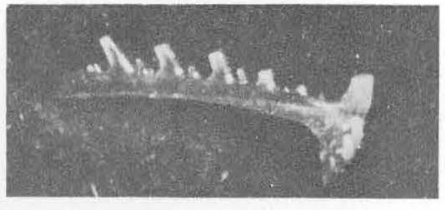

10

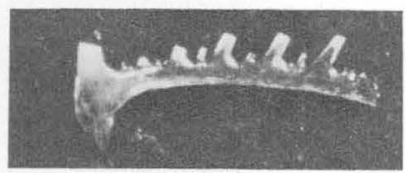

11

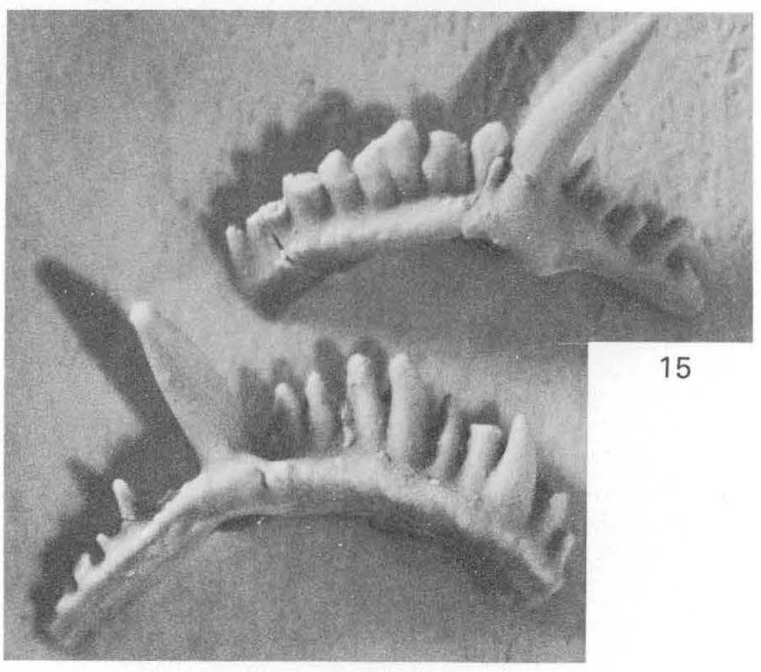

17

LIGONODINA AND PRIONIODINA 


\section{PLATE 29}

[All figures $\times$ 30. Figs. 4, 8, 9, 11, 19 coated; others not coated]

1-4. Bryantodus? aversus (Stauffer) (p. B34).

Inner, outer, and aboral views uncoated, and coated outer view, USNM 188905; USGS 4567-SD, Geneseo Shale Member of Genesee Formation, Elevenmile Creek (At-1). Differs from B. colligatus in the twisted bar and lack of cusp.

5-7. Prioniodina compressa Branson and Mehl (p. B46).

Inner, outer, and aboral views, USNM 188992; USGS 8961-SD, Genundewa Limestone Member of Genesee Formation, Dewey Hill (Cl-5).

8, 9. Prioniodina dialata (Bryant) (p. B46).

8. Outer view, USNM 135012, North Evans Limestone of Rickard (1964), Eighteenmile Creek (Ed1). Specimen figured by Bryant (1921, pl. 2, fig. 7) as Prioniodus recedens.

9. Inner view, USNM 188750; USGS 4586-SD, Genundewa Limestone Member of Genesee Formation, Taunton Gully (Cl-2). See pl. 30, figs. 6-8, for uncoated views.

10-12. Lonchodina subsymmetrica Ulrich and Bassler (p. B45).

Inner, outer, and oral views, USNM 188754; USGS 4577-SD, Genundewa Limestone Member of Genesee Formation, Taunton Gully (Cl-2).

13-17. Trichonodella blanda (Stauffer) (p. B43).

13-15. Outer, aboral, and inner views, USNM 188986; USGS 4562-SD, Penn Yan Shale Member of Genesee Formation, Cayuga Creek (Dp-3).

16,17. Outer and inner views, USNM 188987; USGS 4562-SD, Penn Yan Shale Member of Genesee Formation, Cayuga Creek (Dp-3).

18, 19. Bryantodus tortus (Branson and Mehl) (p. B38).

Outer and aboral views, USNM 188908; USGS 4574-SD, Genundewa Limestone Member of Genesee Formation, Elevenmile Creek (At-1). 
GEOLOGICAL SURVEY
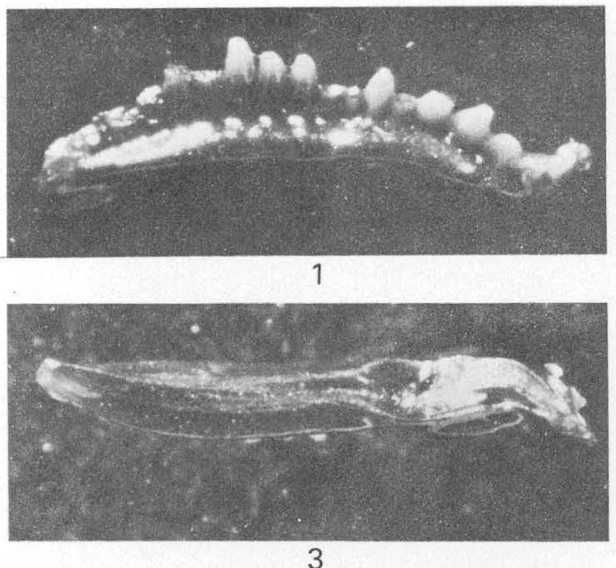

3

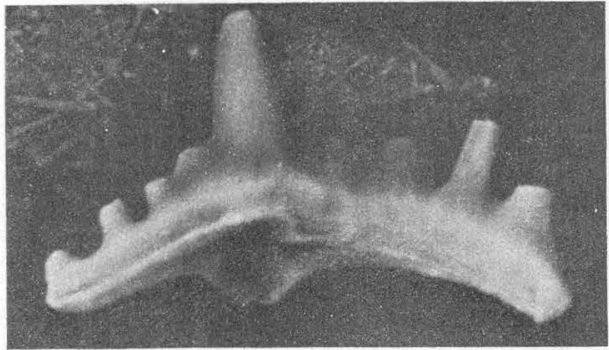

9

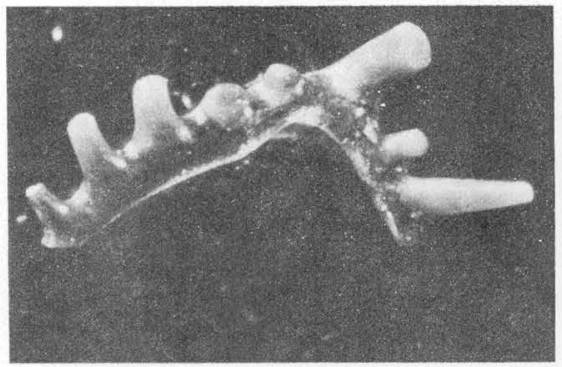

10

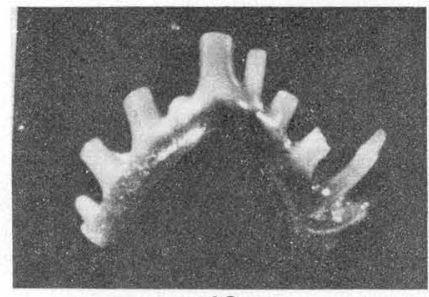

13
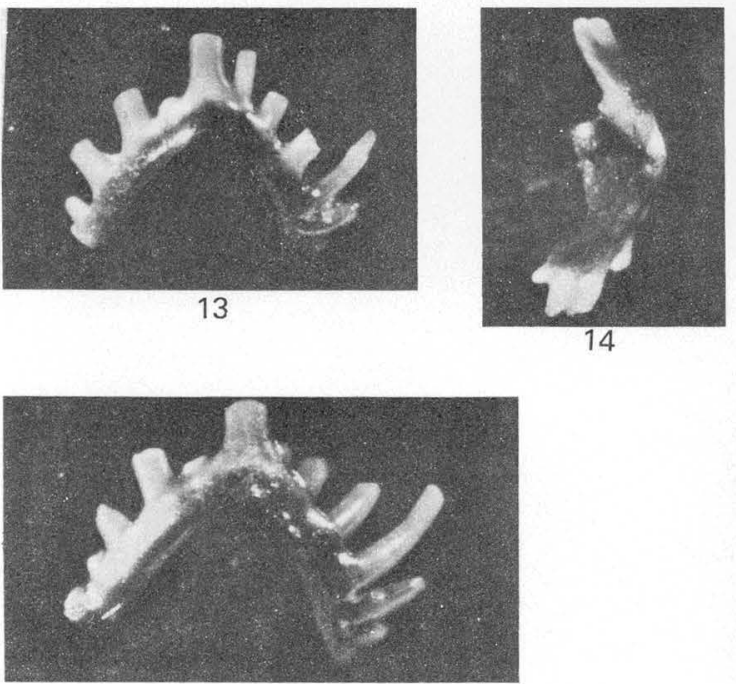

16
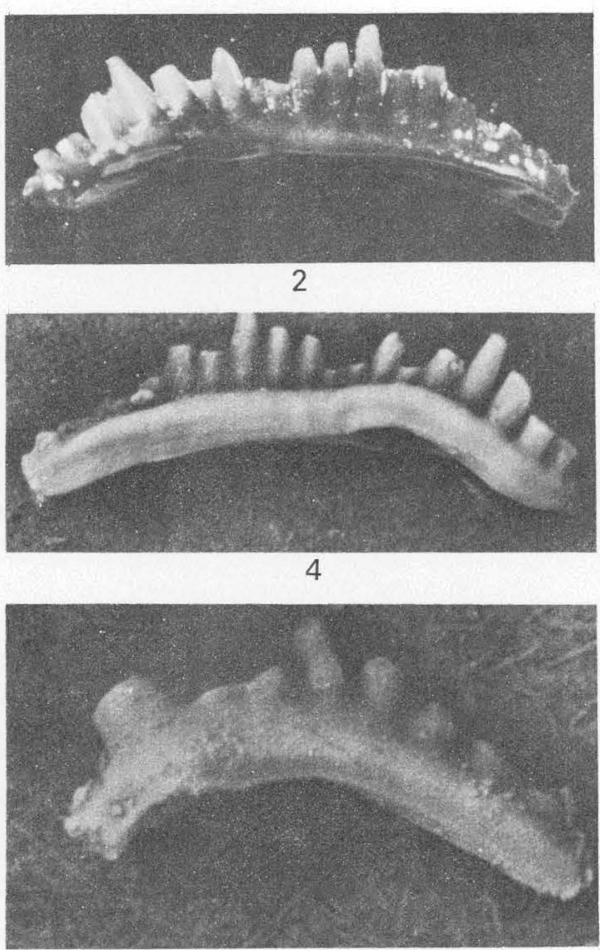

8

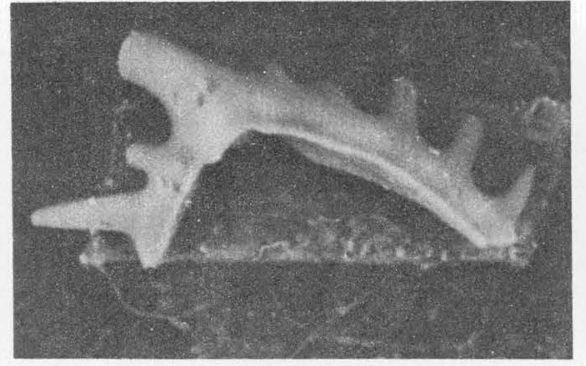

11

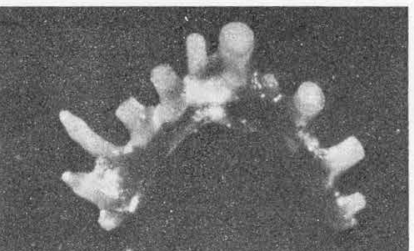

15

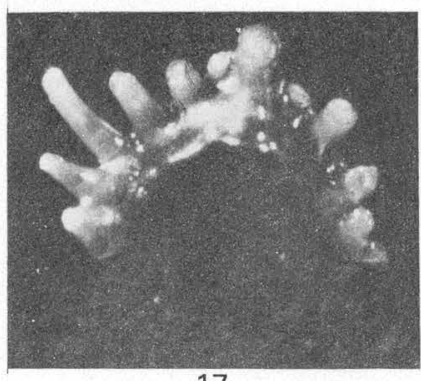

17
PROFESSIONAL PAPER 1032-B PLATE 29

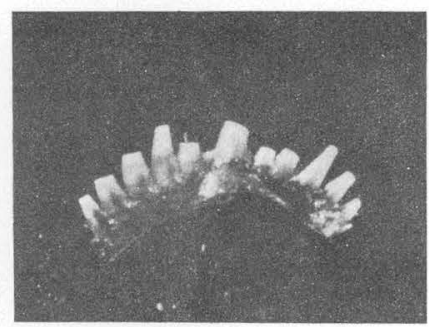

5

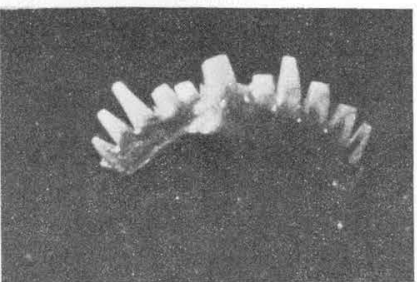

6

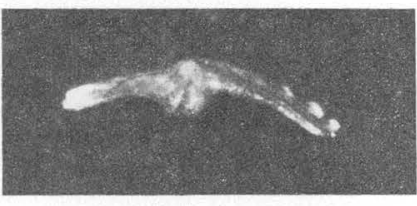

7

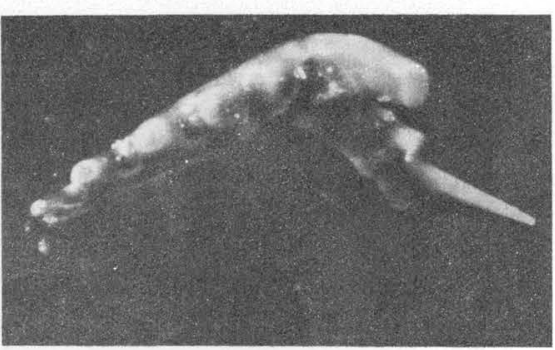

12

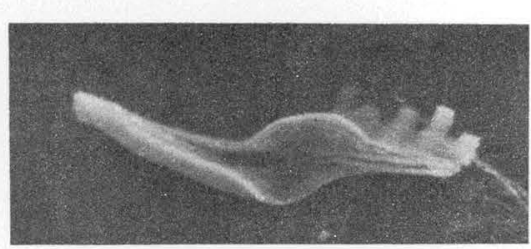

19

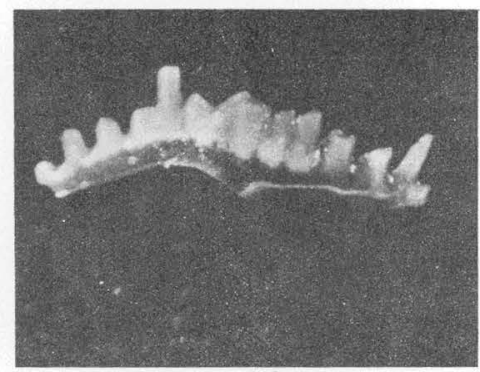

18

BRYANTODUS, PRIONIODINA, LONCHODINA, AND TRICHONODELLA 


\section{PLATE 30}

[All specimens $\times 30$. All specimens are uncoated]

Figures 1-8. Prioniodina dialata (Bryant) (p. B46).

1,2. Oblique-inner and outer views, USNM 188746; USGS 4577-SD, Genundewa Limestone Member of Genesee Formation, Cayuga Creek (Dp-3).

3-5. Aboral, outer, and inner views, USNM 188748; USGS 4538-SD, Leicester Marcasite Member of Moscow Formation of Sutton (1951), Eighteenmile Creek (Ed-1). Note twist that affects basal cavity.

6-8. Outer, oral, and aboral views, USNM 188750; USGS 4586-SD, Genundewa Limestone Member of Genesee Formation, Taunton Gully (Cl-2). Note lack of twisting of bar. See pl. 29, fig. 9, for coated inner view.

10,11. Lonchodina aff. L. typicalis Ulrich and Bassler [not discussed in text].

Inner and outer views, USNM 188751; USGS 4875-SD, Genundewa Limestone Member of Genesee Formation, Bristol Center (Cd-4).

9. Trichonodella blanda (Stauffer) (p. B43).

Inner view, USNM 188988; USGS 6733-SD, Tully Limestone, Gage Gully (Cd-12).

12-17. Lonchodina clavata (Hinde) (p. B45).

12-14. Inner, outer, and aboral views, USNM 188985; USGS 3958-SD, Genundewa, Limestone Member of Genesee Formation, Genundewa Point (Nap-4). Note slight twist of bar.

15-17. Outer, inner, and aboral views, USNM 188747; USGS 8974-SD, West River Shale Member of Genesee Formation, Pike Creek (SC-1).

18, 19. Bryantodus? aversus (Stauffer) (p. B34).

Outer and inner views, USNM 188982; USGS 6733-SD, Tully Limestone, Gage Gully (Cd-12). 
GEOLOGICAL SURVEY
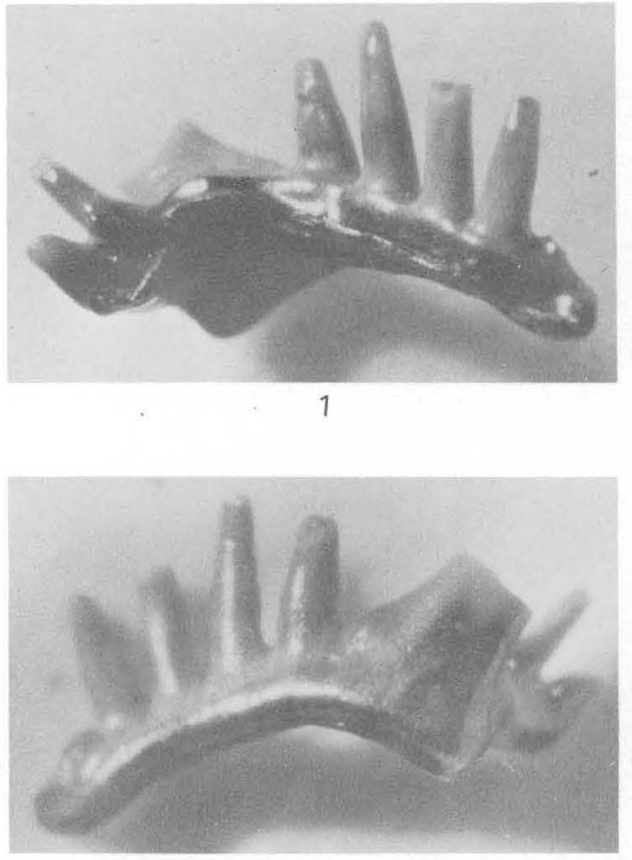

2

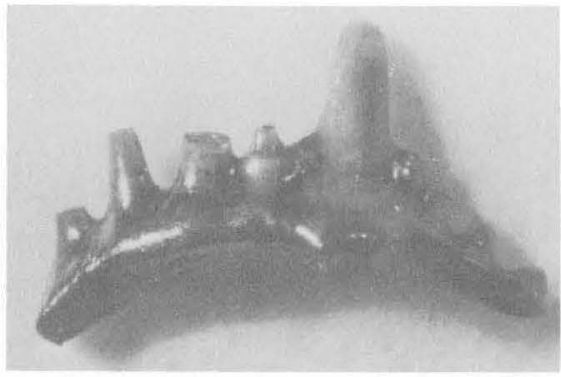

6

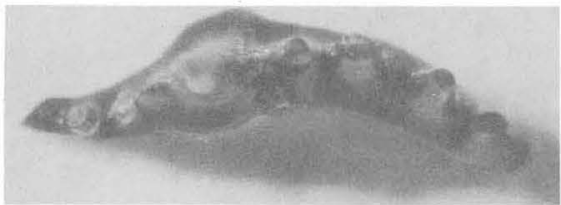

7

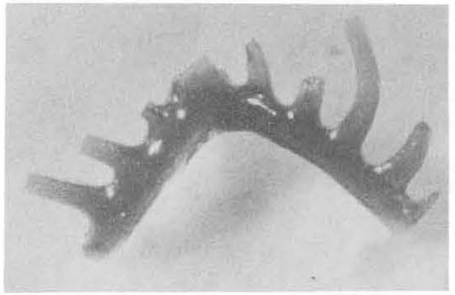

16
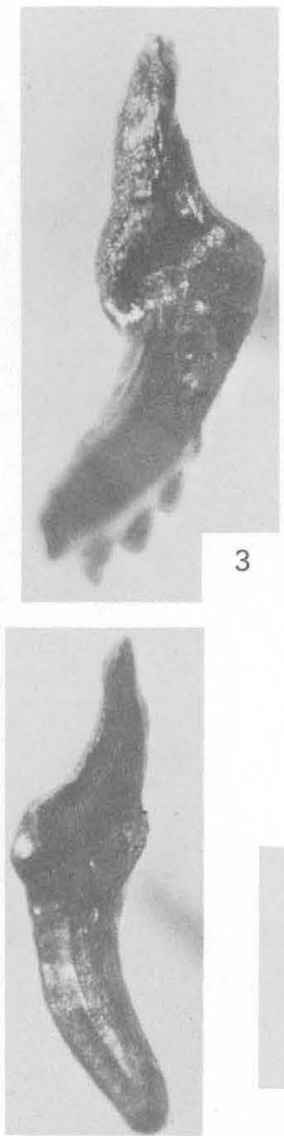

8
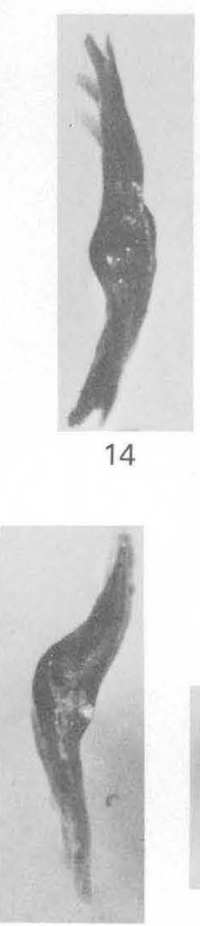

17

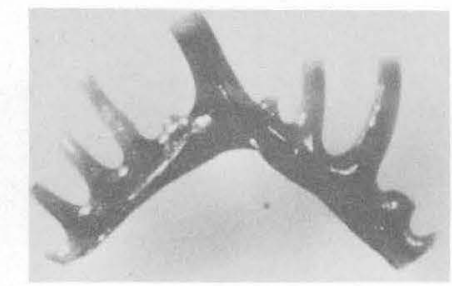

12

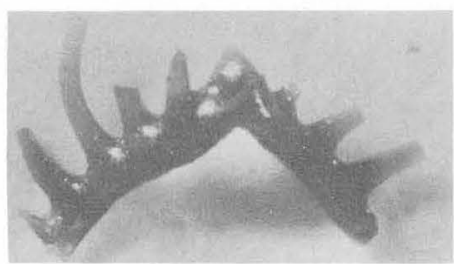

15

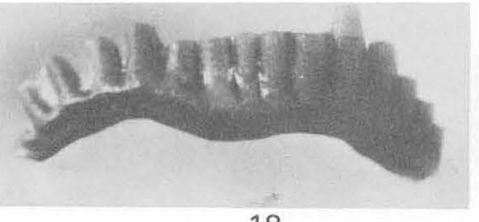

18
PROFESSIONAL PAPER 1032-B PLATE 30

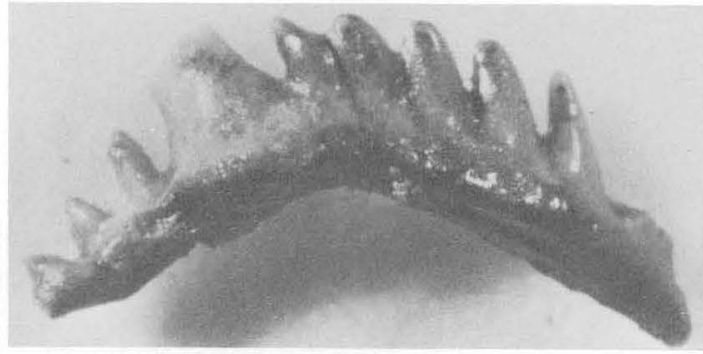

4

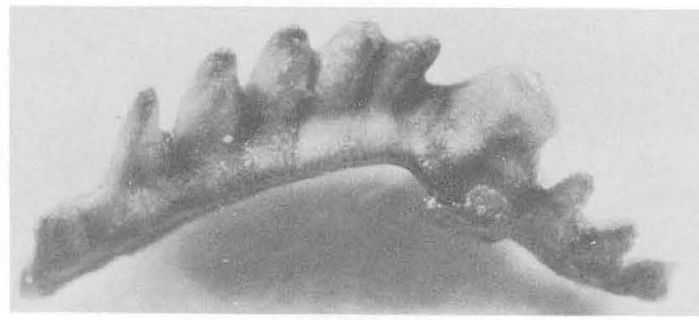

5

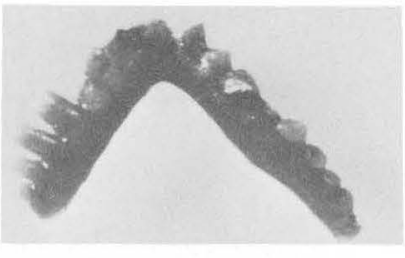

10

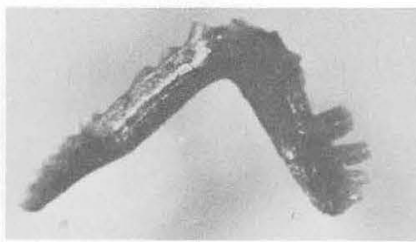

11

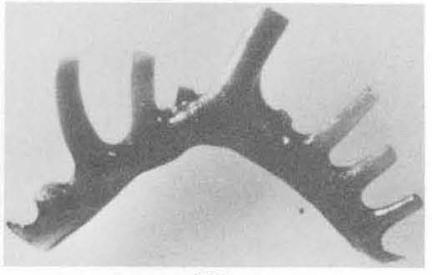

13

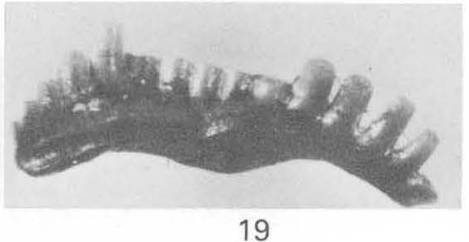

PRIONIODINA, LONCHODINA, TRICHONODELLA, AND BRYANTODUS? 


\section{PLATE 31}

[All figures $\times 30$. Figs. 1, 6 coated, others not costed]

Figures 1-10. Bryantodus tortus (Branson and Mehl) (p. B38).

1-4. Outer, inner, aboral, and oral views, USNM 188753; USGS 4534-S.D, Genundewa Limestone Member of Genesee Formation, Eighteenmile Creek (Ed-1).

5-7. Outer, inner, and aboral views, USNM 188752; USGS 6715-SD, Penn Yan Shale Member of Genesee Formation, Genundewa Point (Nap-4).

8-10. Outer, inner, and aboral views, USNM 188749; USGS 8122-SD, West River Shale Member of Genesee Formation, Fall Brook (Cl-4).

11-13. Lonchodina richteri Bischoff and Ziegler (p. B45).

Inner, outer, and aboral views, USNM 188983; USGS 4525-SD, Genundewa Limestone Member of Genesee Formation, Pike Creek (SC-1).

14-21. Prioniodina compressa Branson and Mehl (p. B46).

14, 15. Inner and outer views, USNM 188990; USGS 8122-SD, West River Shale Member of Genesee Formation, Fall Brook (Cl-4).

16,17. Inner and outer views, USNM 188981; USGS 6737-SD, Genundewa Limestone Member of Genesee Formation, Washburn Cemetery $(\mathrm{Ph}-1)$. Note tendency of denticles to alternate.

18,19. Outer and inner views, USNM 188989; USGS 8122-SD, West River Shale Member of Genesee Formation, Fall Brook (Cl-4).

20,21. Outer and inner views, USNM 188991; USGS 8122-SD, West River Shale Member of Genesee Formation, Fall Brook (Cl-4).

22-24. Lonchodina subsymmetrica Ulrich and Bassler (p. B45).

Outer, inner, and aboral views, USNM 188745; USGS 8122-SD, West River Shale Member of Genesee Formation, Fall Brook ( $\mathrm{Cl}-4)$. 


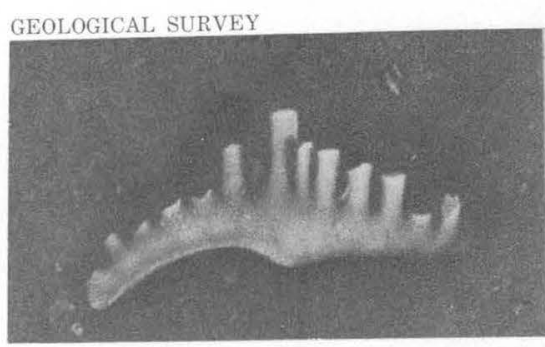

1

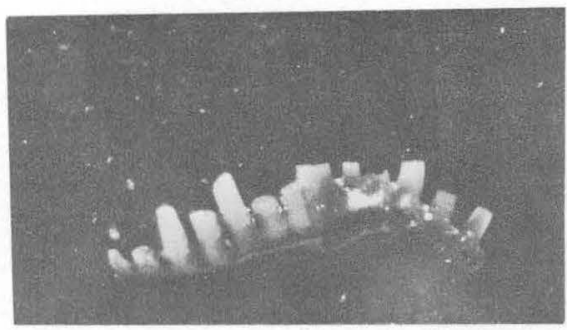

5

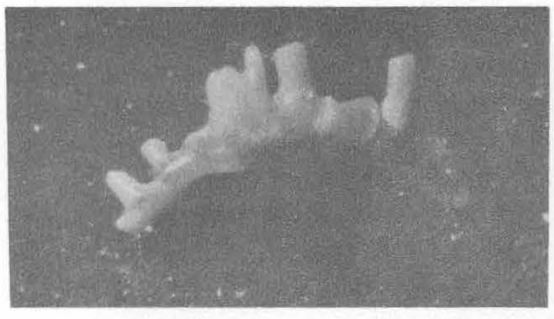

8

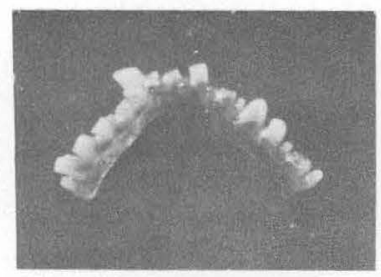

11

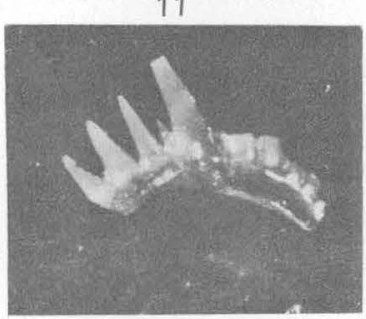

16

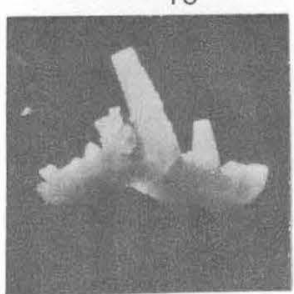

20

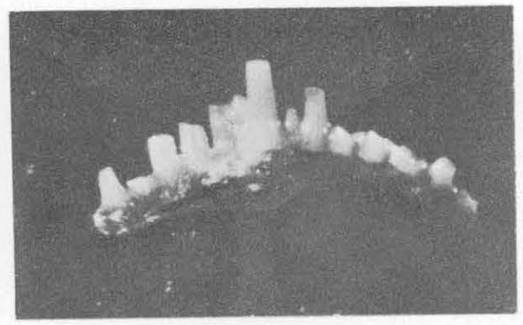

2

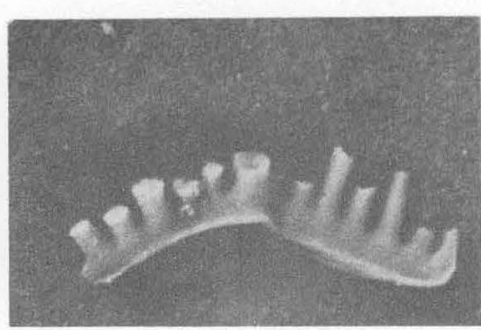

6

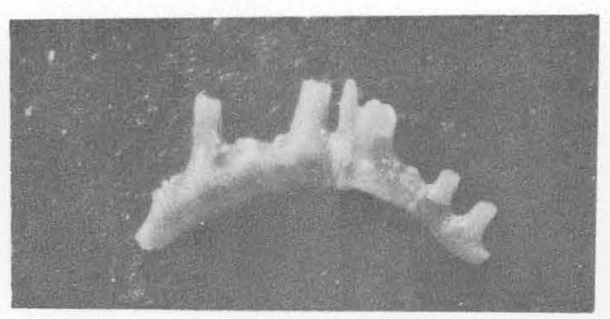

9

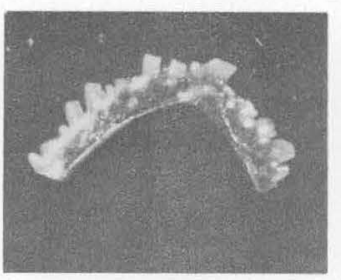

12

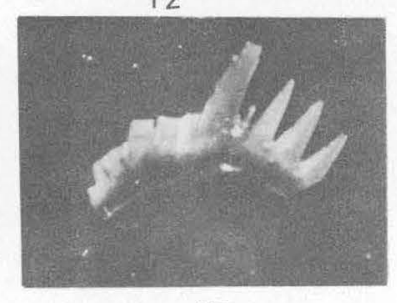

17

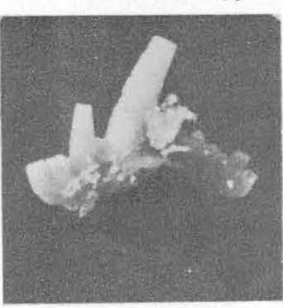

21

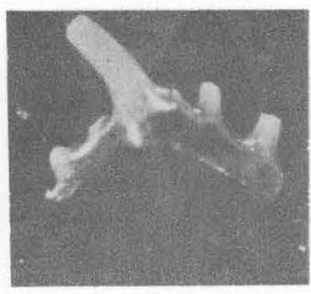

PROFESSIONAL PAPER 1032-B PLATE 31

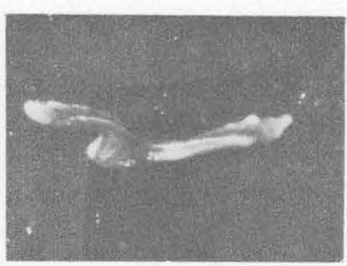

13

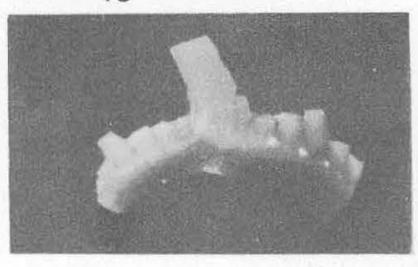

18

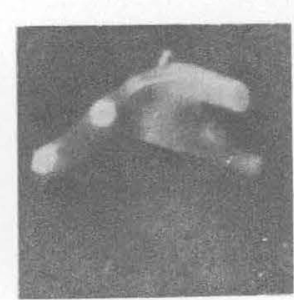

23

14

22

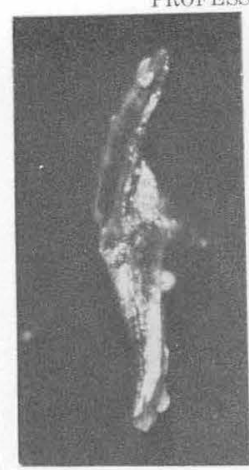

3

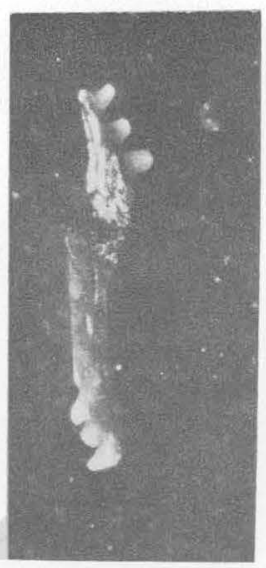

7
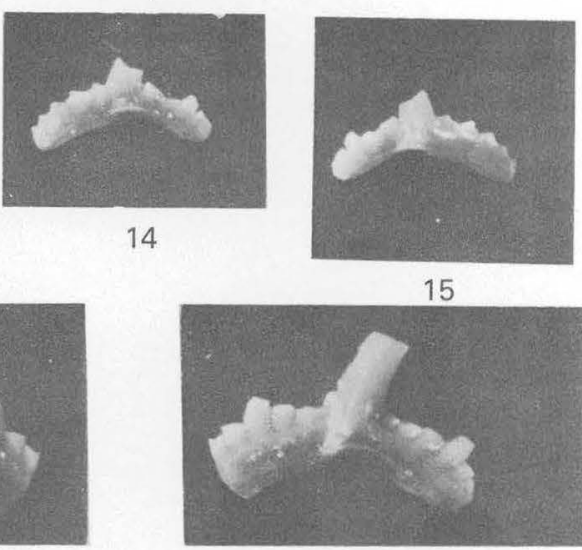

19

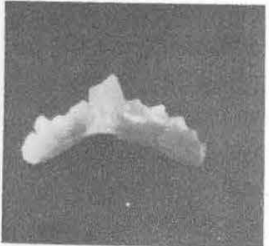

15

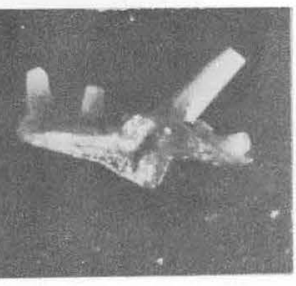

24

BRYANTODUS, LONCHODINA, AND PRIONIODINA 